\title{
THEORETICAL AND APPLIED ASPECTS OF THE DEVELOPMENT OF MODERN PSYCHOLOGY AND PEDAGOGY
}

\section{Collective monograph}

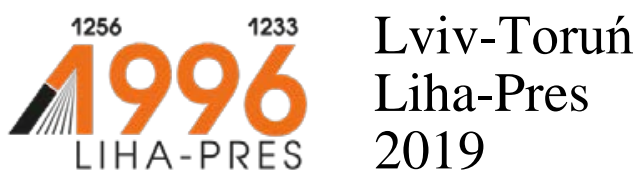




\section{Reviewers:}

Konrad Janowski, PhD, Vice-dean of the Faculty of Psychology, University of Economics and Human Sciences in Warsaw (Republic of Poland);

Prof. dr hab. Tadeusz Dmochowski, University of Gdansk (Republic of Poland).

Theoretical and applied aspects of the development of modern psychology and pedagogy: collective monograph / S. P. Bielavin, T. I. Bielavina, I. N. Bila, T. O. Kostina, etc. - LvivTorun : Liha-Pres, 2019. - 228 s.

ISBN 978-966-397-112-4

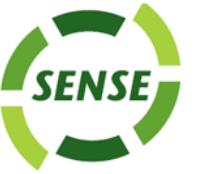

Liha-Pres is an international publishing house which belongs to the category „C” according to the classification of Research School for Socio-Economic and Natural Sciences of the Environment (SENSE) [isn: 3943, 1705, 1704, 1703, 1702, 1701; prefixMetCode: 978966397]. Official website - www.sense.nl.

The monograph is devoted to the consideration of theoretical and applied aspects of the modern pedagogy and psychology.

In particular, the essential properties of current training of future specialists, factors of its effectiveness, its key elements, principles, functions, means and techniques of project training and features of using the project method from the positions of the competence approach are analysed.

The signs of the traditionally leading institution of socialization have been defined: conservatism, unification, limitations of influence in time, and the existence of a corps of professional socializers. The importance of a detailed study of the problem of marginalization, the conditions and resources for the demarginalization of the pedagogical community and its individual segments have been emphasized.

In addition, the main trends and directions in the study of ethnogenesis, ethnic consciousness and ethnic culture of the Crimean Tatars are being considered. 


\section{CONTENTS}

INTRODUCTION 1

FORMATION OF ASSERTIVENESS AS A MEANS

OF EQUALIZATION OF COMMUNICATIVE INTERACTION

IN POLYETHNIC SPACE OF UKRAINE

Bielavin S. P.

THE ROLE OF SOCIO-PSYCHOLOGICAL FEATURES

OF THE PEDAGOGICAL COMMUNITY IN THE FORMATION

OF THE SOCIAL PICTURE OF THE WORLD

OF UKRAINIAN YOUTH

Bielavina T. I.

PSYCHOLOGICAL BASIS OF CREATIVE PERSONALITY

DEVELOPMENT AT THE STAGE OF CHILDHOOD

Bila I. N.

GENDER APPROACH AS A NECESSARY CONDITION

FOR FORMING GENDER COMPETENCE

OF STUDENTS' YOUTH

Kostina T. O.

PSYCHOLOGICAL AND PEDAGOGICAL BASES FORMING

OF PROFESSIONAL COMPETENCE OF THE FUTURE EXPERT

Kostyuchenko O. V. .78

IRRATIONAL CONCEPT OF MANAGEMENT EDUCATION

Kovalenko Ye. Ya. 101

CONDITION OF DEVELOPMENT AND PROBLEMS

OF MODERN EDUCATION FOR ADULTS

Maslianikova I. V. 120

THEORETICAL AND METHODOLOGICAL APPROACHES

TO DEFINING THE SUBJECT OF THE METHODS OF TEACHING HUMANITARIAN DISCIPLINES AT HIGHER SCHOOL

(AS EXAMPLIFIED BY THE MULTICULTURAL

EDUCATIONAL MODEL)

Nediukha M. P. 


\section{PEDAGOGICAL PROJECT DESIGN}

IN EDUCATIONAL ACTIVITY

Radomsky I. P.

MODERN PSYCHOLOGICAL AND PEDAGOGICAL

TECHNOLOGIES FOR THE DEVELOPMENT

OF STUDENTS' CREATIVITY

Vynohradova V. Ye

PSYCHOLOGICAL PECULIARITIES OF REGULATION

OF MOTOR ACTIONS OF OLIGIPHRENS WITH THE HELP

OF SEMANTIC TASKS

Zhyljak N. V. 


\section{INTRODUCTION}

Modern society is facing the challenge of rapid change. Today, more and more situations arise when established norms, rules, patterns no longer work and it is necessary to look for new ones. The search for answers to the posed challenges is primarily intended to be carried out by science and its representatives - scientists. When we talk about changes in society, we take a look at psychology and pedagogy, since these very sciences are called upon to find new ways and methods that contribute to the flourishing of the society.

Therefore, the main goal of the authors of this monograph is to study a wide range of scientific issues that reveal the theoretical and applied aspects of modern pedagogy and psychology.

The paper presents the main issues of the educational space of modern Ukraine: adult education, the introduction of pedagogical design in educational activities, the search for new concepts of managerial education, the implementation of a gender approach in working with students, the basics of building professional competence of a future specialist, the influence of the pedagogical community on shaping the social picture of the youth world. The psychological foundations of a creative personality development at the stage of childhood have been presented; the psychological and pedagogical technologies for the development of students' creativity have been specified. In the context of introducing inclusion into the educational space, psychological features of working with people with special needs have been provided.

The events unfolding in the Ukrainian society require coverage of the issues that are of high theoretical and practical importance for building peace in the Ukrainian state. That is why the monograph presents studies of ethnopsychogenesis and ethnic consciousness of the Crimean Tatars. The role of assertiveness for balancing communicative interaction in the multi-ethnic space of Ukraine has been defined.

The monograph is intended for a wide range of readers seeking to obtain new knowledge and increase the level of scientific outlook. 


\section{FORMATION OF ASSERTIVENESS AS A MEANS OF EQUALIZATION OF COMMUNICATIVE INTERACTION IN POLYETHNIC SPACE OF UKRAINE}

\section{Bielavin S. P.}

\section{INTRODUCTION}

The growth of the scientific interest of social psychology in questions of interethnic relations is reflected in the development of a number of problems: the social psychology of the community, its place in the system of interethnic relations ${ }^{1}$, interpersonal and intergroup perception, in particular in the area of the interconnection of national identity and language ${ }^{2,}{ }^{3}$, the phenomenology of ethnic stereotypes in the space of interethnic relations ${ }^{4,5}$, socio-psychological processes and mechanisms of social perception.

Social perception in them acts as a regulator of communication and the structure of the perception of "other" people and groups: perception of the context of the situation, reflection, interpretation, evaluation in it of yourself and "other".

In this sense, a certain place in the structure of the perception of the "other" is the principle of reflected subjectivity ${ }^{6}$ as an ideal representation of one person in another, as a source of transformation meaningful to another situation. We are talking about "the personal being of man in the world, in the life of others, in the extension of a person in another person."

The ability of a person does not depend on external influences and assessments, the ability to respond adequately to acute situations, to independently regulate and be responsible for his own behavior, the ability to defend his mind without violating the rights of another person, is

1 Васютинський В. О. Російськомовна спільнота в Україні: загрози ідентичності і постави щодо інтеграції / В.О.Васютинський // Науковий вісник Львівського державного університету внутрішніх справ. - Львів, 2008. - Вип.1. - С. 37-45.

2 Голота А. С. Соціально-психологічні особливості етнонаціональної ідентичності українськоросійських білінгвів : автореф. дис. на здобуття наук. ступеня канд. психол. наук : 19.00.05 «Соціальна психологія; психологія соціальної роботи» / А. С. Голота - К., 2012. - 18 с.

3 Донцов А. И. Язык как фактор этнической идентичности / А. И. Донцов, Т. Г. Стефаненко, Ж. Т. Уталиева // Вопросы психологии. - 1997. - № 4. - С. 75-86.

${ }^{4}$ Слюсаревський М. М. Ілюзії і колізії: Нариси, статті, інтерв'ю на теми політичної та етнічної психології / М. М. Слюсаревський. - К. : Гнозис, 1998. - 233 с. - С. 58-81. С. 68-81.

${ }^{5}$ Стефаненко Т. Г. Социально-психологические аспекты изучения этнической идентичности [Электронный ресурс] / Т. Г. Стефаненко. - М. : Флогистон, 1999. - Режим доступа : http://flogiston.ru/ articles/social/etnic.

${ }^{6}$ Психология развивающейся личности / Под. ред. А.В.Петровского; Науч-исслед. ин-т общей и педагогической психологии Акад.пед. наук СССР. - М.: Педагогика, 1987. - С. 20-21. 
ensured by a confident adequate, flexible and divergent behavior, which is called assertiveness.

Assertiveness, in our case, should be understood as a complex psychological phenomenon, "... which is a reduction factor in terms of manifestation of aggressiveness, violations of the psychological personality space and socio-psychological tension in society as a whole"7.

Summarizing the achievements of different authors, we can conclude that assertiveness is the best option between aggressive and passive behaviors. It is aimed at achieving a mutual balance of subjects of interaction, on the realization of their own interests in the conditions of realization of interests of all $8,9,10,11$.

\section{Formation of assertiveness as a means of balancing intercultural communication}

In previous publications ${ }^{12}$, the 7 th factor structure of social perception of ethnolinguistic communities was identified: "communicative engagement", "issuance of approval", "intimacy of personal space", "criticism", "neglect of others", "depreciation of relationships", "Attributive empathy".

The task of the research was to confirm that the identified factors of social perception are actualized in the context of the interaction between ethnolinguistic groups and their representatives in opportunistically conditioned social situations (extreme, subjectively significant, frusturing), which contributed to the strengthening of positive or negative components of social perception.

The format of the experiment used the technique of intragroup discussion in microgroups and the next intergroup discussion.

In order to fix the changes of the dependent variable, a questionnaire was used to assess the ethnic and linguistic categories at the beginning

7 Марчук Л. М. Асертивність як комплексна інтегральна характеристика особистості [Електронний ресурс] / Л. М. Марчук // Вісник Нац. академії Держ. прикордонної служби України. 2012. - № 5. - Режим доступу : http://archive.nbuv.gov.ua/e-journals/Vnadps/2012_5/12mlmiho.pdf.

8 Каппони В. Как делать все по-своему или Ассертивность - в жизнь / В. Каппони, Т. Новак. СПб. : Питер, 1995. - 186 с.

9 Леонтьев А. А. Ассертивность. Общение и деятельность общения / А. А. Леонтьев. - СПб. : Питер, 2008. - С. 160-215.

${ }^{10}$ Хохлова Е. В. Конструктивная агрессивность в формировании навыков ассертивного поведения студентов вуза : автореф. дисс. на соискание учен. степени канд. психол. наук : спец. 19.00.07 «Педагогическая и возрастная психология» / Е. В. Хохлова. - Нижний Новгород, 2008. - 26 с.

${ }^{11}$ Шамиева В. А. Ассертивность в структуре личности субъекта адаптации / В. А. Шамиева, К. И. Воробьева // Социально-гуманитарные науки на Дальнем Востоке : сб. статей. - Хабаровск: ДВГУПС, 2009. - № 4. - С. 79-83.

${ }^{12}$ Белавин С. П. Факторная структура социальной перцепции представителей этнолингвистических общностей / С. П. Белавин // Социосфера. - 2013. - № 4 ; ч. 1. - С. 156-161. - (РИНЦ, DOAJ, Google Scholar). 
of the experiment and after the end of the procedure. The results of the estimates of attractiveness proposed in the questionnaire categories by all participants in the experiment, after the procedure, were conventionally distributed on a language basis, and then subjected to statistical processing and further analysis and interpretation.

At this stage 150 students from three universities took part: Kyiv National Taras Shevchenko University, Kyiv National Economic University named after Vadym Hetman, Kyiv National Pedagogical University. MP Drahomanov. The participants in the pilot phase were students who were representatives of three different ethno-linguistic communities: Russian-speaking Russians, Russian-speaking Ukrainians, Ukrainian-speaking Ukrainians. With the help of purposeful influence, it was supposed to detect changes in the structure of the social perception of the participants in the experiment.

Eight experimental groups have been formed, with a relatively equal composition based on age, gender, nationality and language prevailing in personal communication. In seven groups, experimental influence was carried out to check the parameters of social perception within the limits of seven identified mechanisms (one in each group), and the eighth group was a control group. To measure subjective evaluation of ethnolinguistic categories, the subjects were asked to evaluate the degree of subjective attractiveness of these categories of people: four ethnic (Arabs, Ukrainians, Russians, Tatars), four language (Russian-language, Japanese-language, Ukrainian, and Tatar) and eight other (camouflage).

After the preliminary questionnaire, the subjects were offered a stimulating material in the form of text on sharp social themes - ethnic or linguistic confrontation - borrowed from online forums, newspaper articles and other media messages for intragroup discussion in microgroups and intergroup discussions. After the intragroup discussion in the microgroups and intergroup discussions, the subjects were offered a final questionnaire. According to the results of the experiment, it is possible to state statistically significant differences in some of the tested parameters.

Actualization of the factor "expectation of approval" caused among Russian-speakers the deterioration of the assessment of ethnic categories; Significant differences between the indices before and after the experiment at $p \leq 0.05$ were found.

We note that to a large extent this arose due to a decrease in the rating of the category of "Arabs" and somewhat "Ukrainians". As a result of the activation of the "expectation approval" factor, it turned out that 
the representations of the Russian-language subjects of the ethnic category "Arabs" and "Ukrainians" are to some extent "alien", that is, those that threaten their identity, in particular, the language's identity. The ethnic category "Arabs" is shown to them as "distant aliens," and the category "Ukrainians" is "close alien". The "close alien" is more personalized in subjective perception, from which the identity threat is felt more acutely. The difference between the subjective appeal of linguistic and ethnic categories is determined. If the Russian-speaking subjects do not expect approval from representatives of "other" ethnic groups, and perhaps avoid it, Ukrainian speakers do not expect approval from "other" language groups. At the same time, the Russian-language language slightly increased the assessment of the language categories after the experimental procedure.

Actualization of the factor "intimization of the personal space" caused a decrease in the assessment of language categories among the Ukrainian-language subjects; Significant differences between the indicators before and after the experiment were found at the level $p \leq 0.1$, first of all, due to a decrease in the assessment of the categories "Russianlanguage" and "Chinese-language". The categories "Russian-language" and "Chinese-language" are in the presentation of Ukrainian-language tested "strangers", perceived as threatening their linguistic identity. The updating of this factor leads to a strategy of avoiding Ukrainianlanguage communications with Russian and Chinese. Just as in the previous case, Chinese are perceived as "distant aliens," and Russianspeaking "close alien". For the Ukrainian-speaking population, the threat of ethno-identity is precisely Russian-speaking as "close aliens." The Russian-speaking language somewhat improved the attitude to both ethnic and linguistic categories, while Ukrainian-speakers turned it towards deterioration. Ukrainian-speaking people or distance themselves from foreign-speaking communities, or reduce the assessment of the linguistic characteristics of those who distance themselves from them.

Actualization of the factor of "neglect of others", led to a decrease in the assessment of language categories among Ukrainian-speaking Ukrainians; significant differences between the indices before and after the experiment were found at the level $\mathrm{p} \leq 0.1$, first of all, due to the reduction of the Tatars, and to a lesser extent, of the Chinese-speakers. This testifies to a certain "alienation" of the specified categories on a linguistic basis and their rejection and contempt. These categories are not perceived as a significant threat to the identity of Ukrainian-language 
subjects. In general, the evaluators have lowered their assessment of both ethnic and linguistic categories. It is noteworthy that, as opposed to a group of Russian-speaking subjects who lowered the assessment of the ethnic category "Ukrainians" (that is, they treat them as "close alien"), the attitude of Ukrainian-language subjects to the category "Russians" (average 3.8) did not change.

Actualization of the factor "expectation of approval" led to a decrease in the subjective evaluation of ethnic categories among Russian-language subjects, and the effect of the mechanism of "intimization of personal space" led to a decrease in the subjective assessment of representatives of language categories among Ukrainian speakers subjects.

Russian-speaking subjects, both Russians and Ukrainians, significantly reduced the rating of the very categories on an ethnic basis, while the Ukrainian speaking showed changes in the evaluated attitude (deterioration) to language categories, which indicates the greater sensitivity of Ukrainian- speaking subjects to the issues of language than ethnicity. This is due to the fact that Ukrainian speakers, identify themselves and endanger the language. And the representatives of the Russian-speaking community are likely to dominate the ethnic identity, as evidenced by the greater sensitivity to the estimated attitude to ethnicity. At the same time, the Russian speakers somewhat improves the attitude towards language categories and significantly worsens ethnic attitudes.

There were no significant differences in the control group for any parameter.

The experimental study of the factor structure of social perception and the possibilities for its optimization is due to the need to identify changes in the structure of social interaction of representatives of ethnolinguistic communities as a result of a specially organized influence on the estimated attitude to ethnic and linguistic categories as a result of manipulative intervention in the process of assertiveness training. It can be assumed that the optimization of the factor structure of the communicative interaction leads to moral and reflexive processes, aseriveness in interethnic relations, the development of understanding of the existence of the difference between people, tolerance and respect for the otherness, the ability to overcome stereotypes, prejudice, discrimination in interethnic relations, on the basis of language, nationality .

This definition allows us to build a program of training asertivity as a means of optimizing the factor structure of communicative interaction. 
The format of the molding experiment is the social-psychological training of assertiveness, a scenario of training sessions ${ }^{13},{ }^{14}$. Socio-psychological training is the most effective practice of psychological influence, is based on methods of group work, greatly facilitates and accelerates the process of acquiring the ability to find adequate ways of self-knowledge, understanding of others and skills of effective social behavior. Sociopsychological training optimizes the communicative capabilities of the person, more effectively promotes the occurrence of changes in the personality traits necessary for productive interaction in the polynational space, for a more mature reflection. The results of the forming experiment should be approximated to the model of the statistical conclusion about the existence of a causal relationship between the effect and the corresponding effect, that is, between independent and dependent variables of experimental study.

And therefore, the task of this training was to: experimentally confirm that the factor structure of the communicative profile is optimized in the process of a specially organized socio-psychological impact, which determines the moral-reflexive processes and assertiveness in interethnic relations; to contribute to the formation of moral reflection aimed at respecting a person, tolerant attitude and understanding of the existence of the difference between people, acceptance and respect for the otherness; develop: readiness for independent choice of means of establishing nondiscriminatory relations with others, means of realizing human rights at the ethnic, linguistic and general levels; the ability to overcome stereotypes, prejudices that degrade human dignity, discrimination in interethnic relations, language, etc.;

This effect of molding influence is especially needed in multi-ethnic and multicultural societies, which is the Ukrainian society.

Exactly the training of assertiveness that is most justifiable in solving the tasks set. It best determines the development of associativity in interethnic relations of tolerance and respect for the other, the ability to overcome stereotypes, bias on the basis of language, nationality, etc.

Interesting is the aspect of assertiveness, which is related to the ability to optimize the contradictions that arise in ethnic and ethnolinguistic communities and prevent the emergence of their extreme

\footnotetext{
13 Вачков И. В. Психология тренинговой работы: содержательные, организационные и методические аспекты ведения тренинговой группы / И. В. Вачков. - М. : Эксмо, 2008. - 416 с.

14 Милютина К.Л. Тренинг как процесс исследования и моделирования // К.Л. Милютина. Актуальні проблеми психології. Том Х. Випуск 4. / За ред. академіка С.Д.Максименка. - К.: Главник, 2008. - C. 54-60.
} 
forms: stereotyping, bias, stigmatization, discrimination, xenophobia. This phenomenon was laid on the basis of a molding experiment that should help the students to form a constructive way to find the way out of problem situations in communication, to respond optimally to criticism, the ability to resolutely speak to themselves and others, "no", to defend their own position, to achieve life goals, to be responsible for your own choice.

In the course of the molding experiment, the features of social perception and behavior in different conditions of interpersonal and group interaction were investigated, depending on the degree of psychological closeness (in the conditional local space, in a personally important situation in an open social environment), the experience of communication (the presence of stereotypes, prejudices, etc.), in conditions of false information (in accordance with the planned procedures).

The object of the formation experiment was the socio-psychological situation of the interaction of representatives of ethnolinguistic groups, and his subject - the optimization of manifestations of the factors of the communicative interaction of representatives of ethnolinguistic groups.

The experiment in the format of the training of assertiveness was implemented as an interaction organized by the researcher between the group of subjects and the experimental situation in order to establish the laws of this interaction and the variables on which it depends.

It should be emphasized that the participants in the sociopsychological training, belong to such ethnolinguistic communities: Russian-speaking Russians, Russian-speaking Ukrainians, Ukrainianspeaking Ukrainians.

87 students from higher educational institutions participated in the training: Berdyansk State Pedagogical University named after P. D. Osipenko and TG Shevchenko Chernigiv State Pedagogical University. The age range of the subjects is from 18 to 20 years. Five experimental groups were formed, with a relatively equal composition based on age, gender, nationality and language prevailing in personal communication, and one control group.

To measure the subjective evaluation of ethnic and linguistic categories, the subjects were asked to evaluate the degree of subjective attractiveness of such categories of people: ethnic (Arabs, Ukrainians, Russians, Tatars), linguistic (Russian-language, Chinese-language, Ukrainian, Tatar) and other (camouflage). The questionnaire included three categories of categories for ranking. 
The prevailing material for the experimental situation were conditionally indicated as the usual, and conditionally set psychologically dangerous, acute life events, when entering which, the testers can represent the most pronounced "deviations" in actions, forms of behavior from the generally accepted norms in the community.

First, it was necessary to find out how they manifest themselves in the conditional local space in a conditionally isolated group, when the active interaction of the individual with his immediate environment is limited only by an interpersonal relationship within this group and narrow-minded interests.

In such an alternative discipline may be the rigid status hierarchy and the structural division into distinct subgroups. They often have a low level of reciprocity of elections and a high rate of "neglected", but there may also be a high level of intra-group cohesion in relation to the vital events of the group in the proposed circumstances.

When carrying out measurements before and after the training, the conditional situation of getting into an unidentified island was proposed. It was necessary to rank the categories in the list of ethnic, linguistic, socially vulnerable and neutral evaluated on the basis of preferential treatment in the event of such a situation.

Second, it is important to establish how the "significant other" influences the choice, as the factor structure of communicative interaction manifests itself in the situation of taking into account the interests of "significant other". This term is used to identify a loved one that is important in personal life, such as a family member or friend. "Significant Other" affects a person in a certain way, which is expressed in a qualitative change in its semantic formations and behavioral activity.

In a training situation in the role of "significant other" act either brother or sister. For participants before and after the training, it was necessary to rotate the list of ethnic, linguistic, socially vulnerable and neutral rating categories on the basis of giving priority if the brother or sister would be friends or meet with one of the representatives of the specified categories.

Thirdly, how exactly do they manifest themselves in an open social environment, when interethnic interaction does not involve limiting contacts with one's own group, only one language of communication, etc. This implies the interaction of a society involving representatives of various ethnic groups and ethnolinguistic groups, and communication is also realized in other diverse relationships beyond this 
particular group as it is socially developed. Such groups are mainly focused on the primacy of emotional factors, as opposed to joint activities. They are characterized by a low indicator of mutual reference, that is, low indicators of mutual elections and alienation or neglect. In the third conditional situation, such a role was played by a student group, whose method of ranking was to select those for whom the subjects most favored the joint study in the class.

Control over independent and dependent variables was carried out by means of preliminary and control measurements of the attitude towards the ethnic and ethnolinguistic categories being evaluated. There was no molding effect in the control group, and the difference in time between the previous and the final measurements corresponded to the difference in the experimental groups.

The training provided one lesson in each group, which lasted for three hours, and, in addition to the tasks already defined, solved the search tasks of updating certain constructs of socio-psychological mechanisms and controlling changes.

The strategic training line can be defined as receiving new information about yourself, others, relationships with them; reconsideration of representations regarding the image of "I", "We" and "They"; building a new type of relationship with yourself, with others; consolidating the positive experience of communication and overcoming unconventional ways of interaction.

For the control of independent and dependent variables, a questionnaire has been developed that consists of three lists of such evaluable categories: representatives of ethnic, ethnolinguistic, socially vulnerable and neutral strata of the population. Measurement of the results took place "before" and "after" the training of assertiveness, in three series of measurements, taking into account the conditionally chosen situation, with the following instructions:

1) The first conditional situation (here and below): If you were on a deserted island, who would you be more willing to meet in such a situation? In each list of ten categories give first place to those who prefer, then the second most desirable of those who stayed and so on to ten.

2) The second conditional situation (here and below): In the same way, make a ranking of those who would prefer if the brother or sister would be friends or meet with any of the representatives of the specified categories. 
3) The third conditional situation (here and below): By the same method, rank the ones with whom you would be willing to study in one group at the university.

The first list included categories: Arabs, Russians, Bulgarians, students, Ukrainians, athletes, Tatars, Catholics, fellow countrymen, "four-eyes"

The second list consisted of the following rated categories: Russianspeaking; Bulgarian-speaking; Tatar-speaking; Ukrainian-speaking; polish-speaking; Japanese-speaking; people with gypsum on the leg; people with hearing aids; people with a scar on the face; good people.

The third list included categories: carefree, sad, cheerful, calm, indifferent, believers, active, redhead, singing, thoughtful.

The main methods during the training work were group discussion and simulation of the interaction situation in various modifications and in different configurations.

Group discussion is defined as a way of organizing communication of group members. It allows you to discuss the problem from the opposite views, to see the different positions of the participants about it. In a group discussion, an analysis of mental states in the set of possible situations that can cause uncertainty in their actions and judgments. Group members analyze personal experiences, resources and opportunities to overcome contradictions and prejudices in interethnic interaction. In the process of transforming the elements of the value-semantic sphere of the personality there is awareness of their own assertive positions.

The method of modeling the situation allows to actualize in the value-semantic sphere the person changes in the process of acquiring new experience. It helps the individual to acquire the ability to navigate in different situations, updates her readiness to experience conflicts and effects in interethnic communication, constructively, with the preservation of the integrity of their psychic world, self-esteem; overcome difficult life situations, defend their rights, demonstrating positivity and respect for others.

Under these conditions, it's important for every person to understand, understand the significance of another culture, unusual phenomena, and include new knowledge in his cultural arsenal, in the structure of his behavior and lifestyle, to find resources to overcome problems, frustration, personal involvement in the affairs of the state and society. It is important to realize the need to develop tolerance, unbiased attitude to others, and so on. 


\section{Characteristics of changes as a result of optimization of the factor structure of the communicative interaction of representatives of ethnolinguistic groups}

The obtained results before and after the experiment were initially subjected to the procedure of factor analysis by the method of the main components in various conditionally given situations of ethnolinguistic choice (3 series of measurements in accordance with the conditional situations described in the preceding paragraphs), which made a grouping of signs (representatives of ethnic, ethnolinguistic, socially vulnerable and neutral strata of society) based on the most significant correlations between them.

According to the results of factor analysis of the data obtained for the socio-psychological training, in the first conditional situation ("desert island"), 5 factors were distinguished. The total variance of the results of the factor analysis is $51.2 \%$, the cumulative $\%$ of the first three factors amounted to $33.5 \%$.

The first factor united the following categories: on one pole there were Bulgarians, Tatars, indifferent, careless, Arabs; on the other Ukrainians, Catholics, active, countrymen, singers. The categories of "strangers" have certain features of remoteness, indistinct (indifferent), contain ethnic categories that are not prevalent in the territory of Ukraine. This gives grounds for referring them to "distant foreigners."

The second factor combines categories on the basis of ethnolinguistic and neutral direction, namely: at one pole there were categories of united features, socially vulnerable strata of society with a slightly negative tone: people with gypsum on the leg, people with hearing aids, indifferent people with scar on face, students. That is, those that, of course, need sympathy and support, but cannot be classified as "we", although they can be defined as distant "their". At the other end, there were mainly linguistic categories: Polish-speaking, Bulgarian-speaking, calm, who also do not belong to the definition of "we", but rather belong to distant "alien", but abstract, and therefore safer. Although both poles combine the attribution to the "they" group, such a result shows a certain contrast between linguistic categories that do not require emotional expense and those who need help and altruism.

The third factor includes categories that are defined as neutral, so it makes no sense to analyze them thoroughly, but draws attention to the fact that ethnic and linguistic categories also differentiated in opposition to 
"their own - a stranger." At one pole - Japanese-speaking, and on the other side were Ukrainian-speaking and Russian.

The fourth factor combines ethnic and linguistic categories and also defined the bipolar structure where the categories were at one pole: Tatarspeaking, Bulgarian-speaking, Arabs, Russians, carefree, and on the other - "four-eyes", people from scar on the face, redheads, thoughtful. Here the ethnic and linguistic categories are opposed to those who always sympathize.

Interestingly, Russians were among the conditional category "they" on the same level, considering that most of the participants represent the Russian-speaking community in Ukraine, which does not identify itself with native speakers from another state. This can be explained by the fact that the participants of the training were born in an independent state, identify themselves with the Ukrainian community, and Russians may already be perceived as "close alien". Note that the relationship with "close alien" is always more acute, because the threat of identity is more realistic than a distant alien, the threat of identity, from which it has an abstract character (for example, Japanese).

In the fifth factor at one pole, those who speak Polish, and on the other - those who speak Russian. Such a distribution can characterize the presence of hard stereotypes according to ethnic and linguistic features. Other categories characterize the neutral features of social groups.

According to the results of factor analysis of the data obtained after the socio-psychological training in the first conditional situation, also 5 factors were distinguished. The total variance of the results of the factor analysis is $50.8 \%$, the cumulative percentage of the first three factors was $34.0 \%$.

In the first factor at one pole, along with neutral, the categories were grouped according to ethnic and ethnolinguistic characteristics, categories of people with special needs: Ukrainian-speaking, Arabs, people with gypsum in the foot, people with scar on their faces, people with hearing aids ; on the other side, along with the neutral categories, were Polishspeaking, Bulgarian-speaking, and Muslims.

The displacement of categories according to ethnic and ethnolinguistic features towards the socially vulnerable (before the training they were opposed) suggests the emergence of a somewhat sympathetic attitude to them, the idea that after the training the testers had confidence that, along with the socially vulnerable ethnic and ethnolinguistic categories, they deserved on a more tolerant attitude. 
In the second factor, ethnic, linguistic and neutral categories were united on one pole: Polish-speaking, sad, thoughtful, athletes; on the other side, along with neutral categories (thoughtful, cheerful, indifferent) representatives of socially vulnerable categories, namely people with hearing aids, with gypsum on the leg, as well as ethnic, for example, Ukrainians. The socially-vulnerable strata, to which Ukrainians joined the training, are opposed to Polish-speaking on one pole with neutral categories. That is, after the training, Ukrainians were more acceptable to compassion and leniency on themselves.

The third factor is presented: at one pole - Tatars-speaking, Tatars, Russian-speaking who represent the categories "they", that is, "not their own"; on the second: Ukrainians, Ukrainian-speaking, singing, active, that is, "we" or "ours".

Fourth and fifth factors did not reveal evidence for analysis.

Summarizing the results of factor analysis for the first conditional situation, we can determine the tendencies of weakening of negativism, more lenient attitude to the ethnic and linguistic categories. There is a general tendency to mitigate stereotyped ethnic and ethnolinguistic indications. This is confirmed by a combination of factors at one pole, which contrasted in measuring with the training procedure, namely, the categories defined by representatives of socially vulnerable social strata and ethnic and ethnolinguistic categories.

The next step was to create two new variables: the first included all ethnic categories, and the second one - all languages. A linear clustered model based on the MANOVA procedure was constructed to compare the average "before" and "after" experiments in the first series of measurements, in the pre-established ethnic and linguistic variables, among the representatives of ethnolinguistic communities. The criterion of significance was Bonferon's criterion chosen as the most sensitive to the number of measurements.

In the first situation, in the ethnic variable, significant differences between the "before" and "after" experiments were detected. The increase of subjective evaluation of ethnic categories among the Russians tested was revealed. That is, assertiveness in interpersonal and intergroup relations allows optimizing the parameters of social perception. In the linguistic variable significant differences between the "before" and "after" experiments were identified. The subjective evaluation of linguistic categories in groups of Russians and Russian-speaking Ukrainians at the level $\mathrm{p} \leq 0.1$ was found to decrease. Apparently, for Russian-speaking tested language 
identity is a significant or even painful sign. According to the results of the calculations revealed a tendency to improve the attitude towards ethnic communities, and some deterioration of the attitude to the linguistic.

In the second conditional situation ("significant other"), based on the results of factor analysis of the data obtained "before" the procedure of socio-psychological training in the process of polling the total number of test participants training, identified 5 factors. The total variance of the results of the factor analysis is $53.969 \%$, the cumulative percentage of the first three factors was $34.508 \%$.

The first factor is represented: at one pole there were Bulgarianspeaking, Japan-speaking, Tatar-speaking, Arabs, Russians, indifferent; on the other side there were "four-eyes", singers, good people, people with gypsum on the leg. Ethnic and linguistic categories that are at one pole indicate the actualization of ethnolinguistic identity.

The third factor is represented by the following categories: Japanspeaking, fellow countrymen, Catholics, and Ukrainian-speaking at one pole; at the other poles - Arabs, Bulgarian-speaking, careless, Bulgarian, Russians. This contrast shows a comparison of the far and fairly abstract "alien" and more or less "theirs" at one pole, which is consistent with the provisions on the need for psychological safety set forth in the first section. On the other side of the pole are opposing this category of close "strangers", which, constitute a greater threat to the identity of the testers.

In the fourth factor at one pole were Bulgarians, Tatars, sad, Russianspeaking; at the other end, good people, Catholics, calm, people with a scar on their faces, believers. At one pole in this factor, they became significant for the tested categories, which are presumably part of the category "close alien".

The second and fifth factors did not reveal evidence for analysis.

According to the results of factor analysis of data obtained after the socio-psychological training, in the second conditional situation, 5 factors were distinguished. The total variance of the results of the factor analysis is $53.492 \%$, the cumulative percentage of the first three factors amounted to $35.775 \%$.

The first factor is represented by the following categories: at one pole: Bulgarian-speaking, believers, Polish-speaking, Japan-speaking, Tatar-speaking, cheerful, fellow countrymen; at the other poles: people with gypsum on the leg, people with hearing aids, carefree, indifferent, people with scar on their faces, students. Conflict within a single factor of 
socially vulnerable strata and categories that can be generally called "others", or even more or less distant "strangers", indicates a certain degree of social exclusion of the subject.

The second factor is represented by the following categories: at one pole: active, thoughtful, singing, "four-eyes", people with scar on the face, Ukrainian-speaking; at the other poles: Japan-speaking, careless, indifferent, Bulgarians, Arabs, cheerful, sad. Within the limits of this factor the opposition of ethnic and linguistic categories, together with the neutral categories, reveals a certain threat of Ukrainian language from the side of "distant foreigners".

The third factor is represented by the following categories: at one pole: Japan-speaking, Tatar-speaking, Catholics, Redheads, fellow countrymen; at the other poles: Arabs, Russians, athletes, Russianspeaking. Contradiction of the categories of "distant aliens" and "close alien" confirms that with "distant foreigners" under certain conditions one can understand and do not constitute a perceived threat, and "close alien" - clearer, more tangible, and therefore cause a more acute reaction.

Fourth and fifth factors did not reveal evidence for analysis.

According to the results of the factor analysis to the sociopsychological training in the third conditional situation, 5 factors were distinguished. The total dispersion is $56.806 \%$, the cumulative percentage of the first three factors is $37.952 \%$.

The first factor is represented by the following categories: at one pole: Polish-speaking, Bulgarian-speaking, Arabs, Tatar-speaking, Japanspeaking, Bulgarians, sad; at the other poles: people with hearing aids, people with gypsum on the leg, people with scar on the face, "four-eyes", Ukrainians, Redheads.

The second factor is represented by the following categories: at one pole: active, Ukrainian, good people, thoughtful, Redheads, singing; at the other poles: Bulgarian-speaking, Arabs, Tatar-speaking, indifferent, sad, careless. Within this factor, we see the opposition of Ukrainians who are on the same pole with positively connotative categories, other ethnic and linguistic categories, with mostly negative connotations.

The fourth factor is represented by the following categories: at one pole: thoughtful, calm, athletes, Russian-speaking, Russians; at the other poles: people with hearing aids, "four-eyes", good people, Tatars. Regarding this factor, one of the poles along with the categories of Russian-speakers and Russians, got other signs that have a positive connotation. On the other side of the pole - together with the Tatars were 
the categories of socially vulnerable, which can be understood as a rather lenient attitude.

Third and fifth factors did not reveal evidence for analysis.

According to the results of the factor analysis after the sociopsychological training in the third conditional situation, 5 factors were distinguished. The total variance of the results of the factor analysis is $55.669 \%$, the cumulative percentage of the first three factors was $37.440 \%$.

The first factor is represented by the following categories: at one pole: singing, Ukrainian-speaking, “four-eyes", active, thoughtful, fellow countrymen, Ukrainians, people with scar on his face; at the other poles: Bulgarian-speaking, Bulgarians, sad, careless, Arabs. In the context of this factor, we see a socially vulnerable one at the same time with Ukrainianspeaking, which is understood as a lenient attitude towards these categories; On the other hand, they are opposed to other ethnic and linguistic categories that are understood as "not their own".

The second, third, fourth and fifth factors did not reveal evidence for analysis.

After conducting factor analysis in the third series, we again compared the mean values of the rank of ethnic and ethnolinguistic categories by the MANOVA procedure. In the ethnic variable, significant differences were found in the group of Russian-speaking Russians at the level $p \leq 0.1$, that is, there is an increase in the subjective assessment of ethnic categories. In the linguistic variable significant differences were found in the group of Russian-speaking Ukrainians at the level $p \leq 0,1$, that is, there is an increase in the evaluation of these categories. We also see some deterioration in the evaluation of linguistic categories in the group of Ukrainian-speaking Ukrainians.

The general tendency to mitigate stereotyped guides by ethnic and ethnolinguistic features is revealed. This is confirmed by a combination of features at one pole, previously contrasted with the measurement of the training procedure, namely, the categories that define the representatives of socially vulnerable social strata and ethnic and ethnolinguistic categories.

The general attitude towards the estimated ethnic categories in most cases has improved due to the fact that ethnicity is a rather abstract category. The structure of one ethnic group may include many national groups, but their representatives often have a narrow, national identity, so the attitude to ethnic belonging is not so acute. 
In contrast, the attitude to language categories can be divided into three components: the attitude towards "close ones" - Russian-speaking and Ukrainian-speaking in general have improved; the attitude towards "close aliens" - the Bulgarian-speaking and Tatar-speaking categories of evaluation generally deteriorated, the attitude towards "distant foreigners" - rather abstract for the experienced, Polish-speaking and Japan-speaking, has generally improved.

Language is the most significant sign of division into "their" and "strangers", but with some language groups, they are tested or met every day, or at least they know about their presence next to them, and with others - either they are not at all, or so infrequently, that these groups acquire a rather abstract, blurred status of "distant strangers", as Polish and Japanese speakers. So the attitude to "close alien" will always be sharper than to "distant", because "close alien" is always more dangerous.

Reducing the effects of negative stereotypes in the process of perceiving "the other" and the "alien" groups requires the participants to engage in the awareness of their own bias and the desire to change their beliefs based on the values of tolerance, justice, equality and conscience.

In this way, we were able to determine what changes in the social identity of youth occur as a result of one or another factor and whether these changes are related to its influence.

\section{CONCLUSIONS}

Conducting a molding experiment to optimize the intercultural communication of representatives of ethnolinguistic communities in various conditionally prescribed situations, the method of sociopsychological training of assertiveness made it possible to draw separate conclusions.

The general tendency of softening of stereotypical installations according to ethnic characteristics is observed. It is established that the severity of the factors of social perception is actualized and optimized in the process of social interaction between different ethno-linguistic groups or their representatives in different social conditions and situations, provided that they are organized in interaction and assertive behavior.

The identified components of the factor structure of social perception can be optimized in the process of specially organized influence (training of assertiveness), which results in the reduction of the effects of negative stereotypes in the process of perceiving the "other" and "alien" groups and 
requires the participants to understand the interactions of their own bias and the desire to change their beliefs. , based on the values of tolerance, justice, equality and conscience.

Experimental way has been found that optimization of communicative interaction leads to moral and reflexive processes, development of understanding of the existing difference between people and communities on the grounds of language and ethnicity, determines tolerant attitude and respect to the otherness, ability to overcome stereotypes, prejudice, discrimination in interethnic relations. Experimental impact on representatives of ethnolinguistic communities has shown that updating of the factor "expectation of approval" led to a decrease in the assessment of ethnic categories among Russian-speaking subjects; actualization of the factors "intimization of personal space" and "neglect of others" led to a decrease in the assessment of language categories in Ukrainianspeaking subjects.

It is revealed that for Russian-speaking tested language identity is more significant; there was a decrease in the subjective evaluation of linguistic categories in Russian and Russian-speaking Ukrainians. In the ethnic variable in the Russian-speaking Russian group, the subjective assessment of ethnic categories has increased.

The results of the experiment made it possible to conclude that the most sensitive to the influence of the components of social perception in the conditions of ethnolinguistic choice are situations of an open social environment, conditional localized space, the ideal representation of a subjectively significant "other".

It is shown that direct interethnic communication does not necessarily contribute to the optimization of social stereotypes and the destruction of prejudices. Awareness of the similarity of the properties and values of "their" and "strangers" leads to positive changes in perception.

\section{SUMMARY}

The article is devoted to studying the results of experimental influence on representatives of various ethnic and linguistic communities of modern Ukraine, the program and the general course of the experiment are presented, certain conclusions are made.

The general tendency of softening of stereotypical installations according to ethnic characteristics is observed. It is established that the severity of the factors of social perception is actualized and optimized in the process of social interaction between different ethno-linguistic groups 
or their representatives in different social conditions and situations, provided that they are organized in interaction and assertive behavior.

It is revealed that for Russian-speaking tested language identity is more significant; there was a decrease in the subjective evaluation of linguistic categories in Russian and Russian-speaking Ukrainians. In the ethnic variable in the Russian-speaking Russian group, the subjective assessment of ethnic categories has increased.

It is shown that direct interethnic communication does not necessarily contribute to the optimization of social stereotypes and the destruction of prejudices. Awareness of the similarity of the properties and values of "their" and "strangers" leads to positive changes in perception.

\section{REFERENCES}

1. Белавин С. П. Факторная структура социальной перцепции представителей этнолингвистических общностей / С. П. Белавин // Социосфера. - 2013. - № 4; ч. 1. - С. 156-161. - (РИНЦ, DOAJ, Google Scholar).

2. Васютинський В. О. Російськомовна спільнота в Україні: загрози ідентичності і постави щодо інтеграції / В. О. Васютинський // Науковий вісник Львівського державного університету внутрішніх справ. - Львів, 2008. - Вип.1. - С. 37-45.

3. Вачков И. В. Психология тренинговой работы: содержательные, организационные и методические аспекты ведения тренинговой группы / И. В. Вачков. - М. : Эксмо, 2008. - 416 с.

4. Голота А. С. Соціально-психологічні особливості етнонаціональної ідентичності українсько-російських білінгвів : автореф. дис. ... канд. психол. наук : 19.00 .05 «Соціальна психологія; психологія соціальної роботи» / А. С. Голота - К., 2012. - 18 с.

5. Донцов А. И. Язык как фактор этнической идентичности / А. И. Донцов, Т. Г. Стефаненко, Ж. Т. Уталиева // Вопросы психологии. - 1997. - № 4. - С. 75-86.

6. Каппони В. Как делать все по-своему или Ассертивность в жизнь / В. Каппони, Т. Новак. - СПб. : Питер, 1995. - 186 с.

7. Леонтьев А. А. Ассертивность. Общение и деятельность общения / А. А. Леонтьев. - СПб. : Питер, 2008. - С. 160-215.

8. Марчук Л. М. Асертивність як комплексна інтегральна характеристика особистості [Електронний ресурс] / Л. М. Марчук // Вісник Нац. академії Держ. прикордонної служби України. - 2012. - 
№ 5. - Режим доступу : http://archive.nbuv.gov.ua/e-journals/ Vnadps/2012_5/12mlmiho.pdf.

9. Милютина К.Л. Тренинг как процесс исследования и моделирования // К.Л. Милютина. - Актуальні проблеми психології. Том Х. Випуск 4. / За ред. академіка С.Д.Максименка. - К.: Главник, 2008. - С. 54-60.

10. Психология развивающейся личности / Под. ред. А. В. Петровского; Науч-исслед. ин-т общей и педагогической психологии Акад.пед. наук СССР. - М.: Педагогика, 1987. - С. 20-21.

11. Слюсаревський М. М. Ілюзії і колізії: Нариси, статті, інтерв'ю на теми політичної та етнічної психології / М. М. Слюсаревський. - К. : Гнозис, 1998. - 233 с. - С. 58-81. С. 68-81.

12. Стефаненко Т. Г. Социально-психологические аспекты изучения этнической идентичности [Электронный ресурс] / Т. Г. Стефаненко. - М.: Флогистон, 1999. - Режим доступа: http://flogiston.ru/articles/social/etnic.

13. Хохлова Е. В. Конструктивная агрессивность в формировании навыков ассертивного поведения студентов вуза : автореф. дисс. на соискание учен. степени канд. психол. наук : спец. 19.00.07 «Педагогическая и возрастная психология» / Е. В. Хохлова. Нижний Новгород, 2008. - 26 с.

14. Шамиева В.А. Ассертивность в структуре личности субъекта адаптации / В. А. Шамиева, К. И. Воробьева // Социальногуманитарные науки на Дальнем Востоке : сб. статей. - Хабаровск : ДВГУПС, 2009. - № 4. - С. 79-83.

\section{Information about the author:}

Bielavin S. P.

PhD in Social Psychology, Associate Professor at the Department of Psychology and Pedagogy of the Scientific and Humanitarian Institute of the V. I. Vernadsky Taurida National University 


\section{THE ROLE OF SOCIO-PSYCHOLOGICAL FEATURES OF THE PEDAGOGICAL COMMUNITY IN THE FORMATION OF THE SOCIAL PICTURE OF THE WORLD OF UKRAINIAN YOUTH}

\section{Bielavina T. I.}

\section{INTRODUCTION}

In Ukraine, recently, there is a multidimensional process of coexistence and interaction of new ideologies, different cultures and their representatives. This determines the formation of a new social identity, positive and common to the Ukrainian society. Actively involved all strata of society in various activities, which are due to the emergence of new forms of ownership. Against the background of the construction of statehood, the inclusion of citizens in a new system of interpersonal relations, mediated, inter alia, by the building of democratic foundations of society and the development of a culture of civicism is intensified, that is, an intensive personality embedding into the versatile socio-cultural life of modern Ukraine takes place.

In such conditions, the formation of a general and social picture of the world of children, adolescents, youths, youth is carried out. In addition, their life benchmarks are determined. Traditionally, the main institutions of influence on the formation of a person are family and school. At the same time, almost two decades have been marked by a certain activity of a critical analysis of the domestic educational system, which does not manage to overcome the violent changes in public life, values and models of identification. In fact, education gradually loses value itself and becomes only a means of generating high incomes in the future, or, worse, a means of "waiting" for social hardship.

Partial formal and total informal commercialization of education, the gradual aging of the pedagogical corps of the state secondary school, the outflow of young, socially mobile educators, the emergence of social apathy of the share of teaching, even a certain marginalization of the educational community as a whole and its individual components led to a decrease in social efficiency and a reduction in prestige education.

Circumstances and problems that are subjectively perceived by young people as impediments to normal life can be defined as typical situations that simulate typical behaviors, whose manifestations are fixed in determining the typical strategy of a person, such as the ability and 
readiness for a particular choice and the ability to accept certain solution in accordance with the life benchmarks.

Usually the assimilation of norms and values of the actual social space is carried out by the older generation, which can provide young people with the necessary samples of adaptive behavior or through the targeted influence of professional socializers: teachers, educators, psychologists in the education system, social educators, social workers, etc. Therefore, in order to analyze the peculiarities of the pedagogical community and its role in shaping the social picture of the world and the living standards of young people in contemporary Ukraine, it is considered necessary to define a wide range of such problems.

\section{Socio-psychological characteristics of the pedagogical community in modern Ukraine}

During the changes in our state, the whole society at the same time was in a situation of dissonance in all its kinds and circumstances, which require the maximal updating of adaptive resources of the individual. This is especially true for young people who are most vulnerable and most often need social assistance.

In the defined conditions of the development of Ukrainian society and its future there was a problem of determining the socio-psychological specificity of the pedagogical community, its gradual partial marginalization, as well as clarifying the conditions and resources of the demarginerization of separate segments of the educational space on the one hand, and on the other - the role of the pedagogical community in the formation the social picture of the world and the life-marker of the next generation.

That is, the research search within this work is aimed at attracting attention and preliminary analysis of the problem of partial marginalization of the pedagogical community, its psychological components, in particular, the importance of the profession in limiting the resourcefulness of the subject of pedagogical activity, and reducing the effectiveness of its educational effect.

"Transfer of experience to the new generation is an ontological function of a social organism, which needs to be carried out with natural enthusiasm and genuine professional dedication”, V. Tatenko notes, analyzing the socio-psychological problems of reforming education ${ }^{1}$.

\footnotetext{
${ }^{1}$ Татенко В.О. Соціально-психологічні проблеми реформування освіти: спроба системнотипологічного аналізу // Наукові студії із соціальної та політичної психології. - 2005. - № 10 (13). C. 15-35.
} 
But the transition period in the reform of education turned out to be rather problematic and was accompanied by events that had somewhat negative consequences. Partial formal and total informal commercialization of education has led to the fact that commercial educational establishments received a competitive advantage in contrast to the general secondary school. The youngest, active, mobile, flexible group of educational services specialists directed their professional efforts towards non-state-owned educational institutions. This, in turn, led to the gradual aging of the pedagogical corps of the state secondary school, the departure of young, socially mobile educators from it, the emergence of social apathy of the share of teaching as an integrated community, and, to a degree, the marginalization of the teaching community as a whole and its individual components.

The above-mentioned resulted in the tendency to lose part of the layer of intellectuals and intellectuals who would not have nostalgic experiences with the past. Their main function (the transfer to the next generation of basic values and cultural standards within the cultural and normative system of modern society, the formation of a social picture of the world of the new generation) is partially limited to these trends.

Thus, the traditional conservatism of the education system as a function of preserving socially approved values and living standards, material difficulties at the present stage of the formation of Ukrainian statehood, lack of flexibility in the public sector to the introduction of new educational technologies, led to a decrease in social efficiency and a reduction in the prestige of education.

The problem of the influence of the profession on a person and a professional group has traditionally been studied as the relationship between activity and personality in the system of professions "human-human", profession and consciousness, but has not yet been studied in this context. The theoretical foundations of its development are well-known concepts and approaches: general psychological, psychological and pedagogical; socio-engineering, engineering-psychological, and professional studies, which are represented by the researches of E. Klimov², O. Malchazov².

Specifics of social or communicative professions are characterized by the advantage of situations with high emotional saturation and cognitive complexity of interpersonal communication. This requires a

\footnotetext{
${ }^{2}$ Климов Е.А. Психология профессионала. - М.: Педагогика, 1996. - 125 с.

${ }^{3}$ Малхазов О. Р. Психологія праці: навч. посібник для студ. вузів / О. Р. Малхазов. - Київ : Центр учбової літ. (ЦУЛ), 2010. - 206 с. : рис., табл.
} 
specialist significant personal contribution to establishing trust relationships and the ability to manage emotional tension in professional communication.

The professions of the type "human-human" include the so-called "social" or "communicative" professions, which are characterized by "constant intensive communication with colleagues, subjects of professional activity”, namely, managers at all levels, representatives of service occupations, medical workers, workers in the sphere of education (scientific and pedagogical workers of institutions of higher and secondary education, teachers, educators of kindergartens), psychologists, psychotherapists, psychiatrists and others. E. Klimov developed a fourlevel classification of professions on the basis of the subject, goals, means and conditions of work and introduced the concept of professions such as "human-human"1.

A. Pines and E. Aronson, examined the state of physical and emotional exhaustion and other manifestations of disharmony of experiences and behavior as a result of prolonged stay in emotionally difficult situations ${ }^{4}$.

In American psychology, the subject of the study was different - the concept of "engagement" proposed by C. Maslach. Its content characterizes the focus on labor and the positive attitude towards it, enthusiasm, vigor, and efficiency" ${ }^{5}$.

Features of professional stress, its causes and consequences at the employees of educational organizations were investigated by L.O. Kitaev-Smyk ${ }^{6}$. A.O.Rean and A.A. Baranov ${ }^{7}$, L.M. Karamushka ${ }^{8}$ and S.V. Mitina ${ }^{9}$, etc.

"The psychological specificity of stress depends both on external influences, and on the personal meaning of the purpose of the activity, an assessment of the situation in which the person is. Production situations can act not so much as a cause, but as a reason for the emergence of stressful workers. ... The true causes are hidden in personality characteristics: outlook and settings, needs and motives, goals, stereotypes

\footnotetext{
${ }^{4}$ Организационная психология: Учебник (под общей редакцией А.Б. Леоновой) / А. Б. Леонова, М. М. Абдуллаева, Т. Ю. Базаров и др. - ИНФРА-М Москва, 2013. - 429 с.

${ }^{5}$ Maslach, C., Jackson, S. E., Leiter, M. P. Maslach Burnout Inventory Manual (4 Edition). Palo Alto, California: Consulting Psychological Press, Inc., 1997. P. 46-71.

${ }^{6}$ Китаев-Смык Л. А. Психология стреса. - М.: Изд-во «Наука», 1983. - 368 с.

${ }^{7}$ Реан А. А., Баранов А. А. Факторы стрессоустойчивости учителей // Вопросы психологии, 1997. № 1. - C. 45-54.

${ }^{8}$ Карамушка Л. М. Психологія освітнього менеджменту: Навч. посібник. - К.: Либідь, 2004. - 424 с.

${ }^{9}$ Mitina S.V. The factors of emotional burnout of the teacher of the higher educational institution. Psychological and pedagogical problems of modern specialist formation. Warsaw: ANAGRAM Publishing House, 2017. № 1. P. 34-37.
} 
of perception, positions in interpersonal interaction, peculiarities of stress resistance or within personality dynamics" 10 .

The traditional conservatism of the school is defined by the needs of the profession, the formal representation of specific institutional values, and with it the personal rigor of the professional socialist, his nostalgic experiences regarding the past definite tasks of society, monoidalogy and logocracy become a significant obstacle for the older generation of teaching on the path of social adaptation to changes in contemporary Ukrainian society. Therefore, it is important to analyze the phenomenon of marginality and to identify the features of the relationship of limited resource of the subject of pedagogical activity and the peculiarities of the professional deformation of the teacher's personality.

So far, in defining the content of the concept of marginality in the practice of using the term itself, there are several disciplinary approaches: in sociology, social psychology, cultural studies, political science and economics, which adds quite a general, interdisciplinary character to the concept itself. The history of the emergence and functioning of the term «marginal» is relatively short, but its methodological universality each time determines a new content in the study of a variety of social processes. The term "marginal” (marginal - from the Latin margo - edge) was originally used to designate entries, marks on the fields; in another sense, it means "economically close to the limit, almost unprofitable". As sociologist he first began to use in his essay "Human Migration and the Marginal Man” (1928) American sociologist Park R.E. (1864-1944) ${ }^{11}$ This work initiated the formation of ideas about the type of "frontier" man, where the notion of marginality determined the position of individuals who are on the verge of two different, conflicting cultures.

By analogy, the post-Soviet era's teaching is at the crossroads of several cultures: the pre-Soviet (in the cultural resources of the family, the notions of knowledge as a model of the intelligentsia, in the values, ideological symbols of their own parents, grandparents), Soviet (within their own experience and their own history) post-Soviet (in new sociocultural landmarks, values), and cultures of the image of the future (in representations and expectations of a new generation). Modern teaching feels "moral confusion" that causes cultural crossings at all

\footnotetext{
${ }^{10}$ Кулик С.М. Психологічні проблеми професійної адаптації вчителів // Актуальні проблеми психології. Том 1.: Соціальна психологія. Психологія управління. Організаційна психологія/ За ред. МаксименкаС.Д., КарамушкиЛ.М. - К.: Інститут психології ім. Г.С. Костюка АПН України. Частина 2, 2001. - С. 201-204.

${ }^{11}$ Park R.E. Human migration and the marginal man // Amerikan Journal of Sociology. Chicago, 1928. Vol. 33. № 6. P. 881-893.
} 
levels, besides, it is still burdened with nostalgic experiences of past stability, certainty, regulation, total normatization of the "Soviet school", prevailing logocracy, and so on.

Socio-psychological adaptation in the conditions of sharp social changes in society can lead to a crisis of personality-role identity. The new situation of existence in society requires new knowledge, approaches, methods of socialization, it predetermines the necessity of pragmatic as the content of education, and the specifics of the means of pedagogical activity. The overcoming of the crisis of personality-role identity is through social and psychological adaptation on the group and personal levels.

The marginal status of the pedagogical community may be due to the marginal situation of the existence of a community (in our case pedagogical), the marginal person of the subject and the object of the educational process (teacher, learner or pupil), marginal group (as subjects, as well as objects of pedagogical activity), as well as the situation of overcoming the marginal crisis.

The state of marginality is due to the general crisis, so the main feature is its forcedness under the influence of external circumstances. Features of the modern socio-psychological specificity of the marginalization of the pedagogical community are determined by the loss of once high social professional status, social relations, value orientations of the most educated groups of people, people with high level of education: etc.

In the periods of social anomy, the absence of norms is accompanied by intensive social changes, the destruction of old norms in the absence of new, the formation of new foundations for the construction of social roles and, respectively, status positions. In general, this state determines the marginal status. Types of marginal positions are diverse. For example, the type of employment spread in the most difficult times of the early and mid-1990s, has led to the emergence of an uncertain set of employment: on the one hand, you need to be active, mobile, able to "earn", on the other - "hold something" in an institution, in a medical institution or an enterprise. A number of education professionals have mercilessed their work, some have lost their job in the specialty, for the most part, for many years, they were in a state of uncertainty about "work without pay".

A huge number of teachers went through the path of the "shuttle economy”, low-skilled work in the service sector, changing status from an educator to the "implementer" of goods in the market, etc., losing subjective identification with the pedagogical community, radically 
changing the content of socio-psychological guidance, breaking the social links The tricks that supported the previous social status.

Modern marginalized communities are built on social changes of the last decades from those "old" groups that already existed in the social space. The pedagogical community at the macro level may to some extent be regarded as marginal as the phenomenon of marginal social structure phenomena in connection with the reorganization or disorganization of social systems as a consequence of the general marginal character of the post-Soviet social space. Against the backdrop of radical changes in society and the construction of statehood and citizenship, questions of significance of the national language, new criteria for identification ("budgeter", "freelancer"), the question of the legitimacy of new institutions (shadow employment), etc., arises.

At the midi level, the marginalization of the pedagogical community is due to a change in the worst part of the socioeconomic status of teaching. Marginality is manifested as a phenomenon of the radical shift of the socio-occupational structure of society and the social status of large groups of the population as a result of the crisis and subsequent reforms. At the forefront is the problem of the need for the formation of new social features of subjects of pedagogical activity, capable of occupying new positions in the labor market in the context of changing the socioeconomic context (educational institutions of various forms of ownership, economic censorship for students, etc.).

At the micro level, the marginal status of the individual or group in the state of uncertainty in the intermediate marginal situation that forms the marginal person by R. Park ${ }^{12}$ needs special attention. The marginal situation of cultural, ideological shock, economic deprivation has a psychoactive effect and causes stress, frustration and other uncomfortable mental states that exacerbate psychological burnout, professional deformation. Such a situation for a part of the pedagogical corps becomes a significant obstacle to the integration into new conditions of society's life. Cognitive dissonance, moral dichotomy, intrapersonal conflict, loss of previous benchmarks and the absence of new forms in some of the features of "man of two worlds": anxiety, rigidity, loneliness, uncertainty of personal value and interpersonal relationships, fear of risk, etc ${ }^{13}$.

The peculiarity of the content of goals and objectives, the specific requirements, the particularity of the contingent of students of the so-

\footnotetext{
${ }^{12}$ Park R.E. Human migration and the marginal man // Amerikan Journal of Sociology. Chicago, 1928. Vol. 33. № 6. P. 881-893.

${ }^{13}$ Там само.
} 
called elite on the economic grounds of educational institutions on the one hand, and the specific conditions and regime requirements of the life of the so-called closed educational institutions on the other, repeatedly reinforce the isolation of groups (as specialists and pupils) from the broader society, substantially impoverishes the variability of social situations of their mutual influence and the system of relations of the subject in social reality. In addition, they significantly remind the system of referential interpersonal relationships, preventing the adequate socialization of the individual.

The local community strives to close itself, inclines itself to a system of personalized relationships that are closed to the outside world (family, intimate circle of communication, corporate group, employees and pupils of law-enforcement institutions). The influence of such a community is determined, firstly, by the power of the group (the normative influence, the result of which is sustainability), and secondly, the desire to coincide with the social determinations of reality, which are based, first of all, on consent (the information influence, the result of which is internalization). Group pressure provides social predictability, arming its means of control, which are determined by the degree of power.

In localized communities, the relationship between teachers and pupils is characterized by a predominantly role-based approach to assessing each other. The significance of the teacher for the pupil is due, first of all, to the degree of the power of an adult in the conditions of relative isolation from the broader society of closed educational institutions, on the other hand, the role of a specialist in providing educational services or the degree of his economic discrimination in private, so-called, elite educational institutions .

Focusing on the educational-disciplinary model of education as part of a nostalgic pedagogical community in the past inevitably leads to a pronounced discrepancy between functional-role expectations, mutual rejection, dissatisfaction with the style of interaction and communication in the community at an educational institution. This leads to specific socio-psychological phenomena inherent in marginalized groups: group embezzlement, psychological isolation of the individual in the middle of the group, corporate identity, violation of communication, destruction of unity. 


\section{A social picture of the world and life orienters of the pupillary youth and student youth of Ukraine}

The modern social reality, the reappraisal of spiritual and material values, the breaking of stereotypes, the destruction of myths, property stratification in society, the loss of values that seemed stable even yesterday, the decline in the reliability of social guarantees causes aggravation of problems in the youth environment, its social disorientation, social passivity of youth, manifestation of absenteeism, apolitical, nonconformism in relation to the values of the majority, the priority of consumer orientations over creative ones.

The generalization of only some of the results of the study to determine the socio-cultural and socio-psychological portrait of pupillary youth and student youth in the southern and eastern regions of Ukraine allowed to outline the spectrum of the problem field of its life.

In the course of the survey, two youth groups aged 16-17 (n-360) and 18-23 (n-360) were interviewed. The choice of age boundaries is conditioned by the relative connection of the age and certain formal definitions of the social status of respondents: 16-17 years old - receiving secondary education for the overwhelming majority of young people in general and special educational establishments, the period of professional self-determination; 18-23 years old - a period of professional development, therefore, students' youth were questioned.

The general characteristics of modern youth make it possible to determine the indicators of the distribution of responses from various aspects of social life and attitudes toward it: trust - distrust, optimism and pessimism, level of satisfaction with life and hope for the better.

The distribution of answers to the question "Do you trust people around you?" Indicates the relative social loyalty of respondents. "Yes" answered $44.2 \%$ of pupils, 30.5\% - students. Uncertainty and distrust in the social environment are felt by almost a third of students (28.7\%) who answered "no" definitely, as well as $18.8 \%$ of pupils. That is, the level of depersonalized trust in the social environment and the degree of critical assessment of the social environment and its influences to a degree depends on the age and educational level.

A higher level of trust, traditionally associated with the positive direction of expectations and claims (44.2\%), on the one hand, and relatively low criticality in the assessment of society (18.8\%) on the other, is inherent in early adolescence. It can be a source of socializing influences as a positive, prosocial content, and vulnerability to the effects 
of negative meaning. The high significance of communication with peers, the trust and reference of peer evaluative judgments on various issues of personal and social life are an important resource in the development of socializing programs.

For a more complete understanding of different segments of the problem field of youth life, it is necessary to determine the peculiarities of its interaction with social reality, typical mental states, the usual ways of responding to the problems, in the context of changing the social, economic and cultural context in Ukraine. Answers to the question "What state do you experience most often?" Allowed to determine the most typical psychological reactions in the present.

The leaders in the most typical psychic states are "expectations for the better" and "determination to improve their lives". At the same time, concerns about typical fatigue, loneliness, anxiety, irritation, which indicate discomfort, a state of psychological danger, that is, the need for help, support, are typical.

Answers to the question "Do you expect change for the better in your life?” Also indicate a general positive mood, some optimism, expectations of a better future (81.2\% of the pupils answered yes, $77.1 \%$ of students). Optimism is inherent in the overwhelming majority of the researchers, gives hope for overcoming psycho-traumatic situations, the search for and use of resources for adequate adaptation and optimal strategies for integration into the modern Ukrainian society. But an insufficiently critical evaluation of a possible future reveals yet few justified expectations.

Table 1

\begin{tabular}{|l|c|c|}
\hline \multirow{2}{*}{ Distribution by answers } & \multicolumn{2}{|c|}{ \% of the number of responses } \\
\cline { 2 - 3 } & $\begin{array}{c}\text { pupils } \\
\text { 16-17 years old }\end{array}$ & $\begin{array}{c}\text { students } \\
\mathbf{1 8}-\mathbf{2 3} \text { years old }\end{array}$ \\
\hline loneliness & 28,7 & 28,2 \\
\hline waiting for the best & 41,4 & 44,3 \\
\hline anxiety & 24,3 & 20,1 \\
\hline irritation & 21,5 & 24,7 \\
\hline confusion & 12,7 & 14,4 \\
\hline resolve to improve life & 37,0 & 33,9 \\
\hline compassion for people & 22,7 & 7,2 \\
\hline fatigue & 20,4 & 30,5 \\
\hline patience and humility & 14,4 & 8,6 \\
\hline other & 7,7 & 5,2 \\
\hline
\end{tabular}


The problem that troubles respondents is united on the question "Which of the following problems worry you personally?". Problems are grouped into blocks of 7 allegations (socio-legal, health, economic, relationships).

Indisputably, the source of anxiety and anxiety in the social-legal block is the lack of jobs (33\% is the average for pupils and students), corruption in the authorities (29\%) and high crime rates (23\%). It can be used as a content component in the development of correctional tools aimed at optimizing integration into the society. Interesting social-role dynamics is observed in relation to the problems: older respondents are concerned about the lack of jobs, and the adolescents are not looking for a job in the future.

Different answers look depending on the age category: in relation to corruption (students - 29,1\%, pupils - 19,3\%) and high crime rate (students - 14,3\%, pupils -23\%). Unfortunately, only a small part of respondents are concerned about the lack of education as a possible resource of a successful career and planning of the future.

Respondents who are current for the present (average): the problems of spreading HIV / AIDS (43.6\%), the spread of drug addiction (29.3\%) and alcoholism (24.5\%) among young people, sexual intercourse, albeit confusing, but not attributed to those that require considerable attention.

The representation of young people about a healthy lifestyle allows you to navigate the semantic space of health culture, but have not yet differentiated superficiality. With age, the attitude to such social aspects ceases to be abstract and the health problem is personalized, becoming the health status of "my and my family members". Young people are surely aware that a large number of "normal" people are smoking, drinking, eating badly and not doing sports. These stereotypes essentially reduce the value of a healthy lifestyle. Attention to ecology is insignificant, but with age it grows (pupils - 12,7\%, students - 24,1\%).

This state of affairs can be explained either by the lack of special information and education materials on a particular topic or by the lack of access to such materials.

The actual sphere of the problems is almost for all respondents the sphere of social contacts: relations in the family (pupils - $24.3 \%$, students $-39.2 \%$ ), friends and peers or loneliness (pupils - $24.5 \%$, students $-38.7 \%$ ), relations with the opposite sex (pupils - $13.2 \%$, students $-16.0 \%$ ), fears do not meet expectations, appearance (pupils $33.8 \%$, students $-38.1 \%$ ). There is a need to learn to communicate, find 
common ground with different people, be assertive, be able to tell the truth, overcome discomfort in communication.

The answers to the question "To whose help you are counting on the most difficult things in the first place?” Most accurately characterize: typical resources of solving problems of a person, typical ways of planning it for the future, externality - internality of adaptive strategies. The obtained results testify to some externality of a significant part of the respondents, that is, they are typical for them - the orientation of expectations in the outside world, the expectation of good luck, friends, parents, even God, and not resorting to their own resources to overcome the difficult circumstances in their lives.

The majority of respondents express confidence that their future depends on them, which is a natural age-old feature of this sample of respondents. This indicator is somewhat lower among students, which is explained by the acquired life experience. Hope for parents, friends, God, the state is more likely to be associated with the peculiarities of the social situation in which their life unfolds.

Table 2

\begin{tabular}{|c|c|c|}
\hline \multirow{2}{*}{ Distribution by answers } & \multicolumn{2}{|c|}{$\begin{array}{l}\% \text { of the number } \\
\text { of responses }\end{array}$} \\
\hline & $\begin{array}{c}\text { pupils } \\
16-17 \text { years old }\end{array}$ & $\begin{array}{c}\text { students } \\
\text { 18-23 years old }\end{array}$ \\
\hline only to myself & 56,4 & 28,2 \\
\hline parents and relatives & 45,3 & 44,3 \\
\hline friends and acquaintances & 21,5 & 33,9 \\
\hline beloved person & 12,2 & 17,2 \\
\hline I rely on good luck & 7,2 & 30,5 \\
\hline I hope only for God & 6,1 & 8,6 \\
\hline other & 1,1 & 5,2 \\
\hline
\end{tabular}

It is clear that pupils' youth and students count on the care of family members, since they do not yet have their own material sources of independent life, but these indicators also indicate the subjective importance of the family as a universal value. The family, being the highest value and resource for achieving meaningful goals, can at the same time serve as an institution for restoring the deficit of depersonalized trust in the world, the social environment, as well as depersonalized violence, social pressure in radical social reality.

Study of the guidelines concerning the conditions for achieving success allows to determine the content and level of motivation for 
achieving success, updating the creative potential of the individual, positive self-affirmation of the individual, revealing the image of a successful person in the consciousness of the subjects.

To a certain extent, the distribution of answers to the question "What is the main guarantee of life's success today?" Can help. Respondents prefer utilitarian, pragmatic conditions for success: money, influential people, ability to adapt, but prevails all the same idea that success can be achieved through reason.

Meanwhile, the "privatization of the public space" inherent in our modern life is due to the "privatization of useful people", the use of them as a scarce resource by transforming them into friends, "friends of our friends”, family members.

Table 3

\begin{tabular}{|l|c|c|}
\hline \multirow{2}{*}{\multicolumn{1}{c|}{ Distribution by answers }} & \multicolumn{2}{c|}{ \% of the number of responses } \\
\cline { 2 - 3 } & $\begin{array}{c}\text { pupils } \\
\text { 16-17 years old }\end{array}$ & $\begin{array}{c}\text { students } \\
\mathbf{1 8}-23 \text { years old }\end{array}$ \\
\hline intelligence & 66,9 & 74,1 \\
\hline physical strength & 17,7 & 15,5 \\
\hline money & 67,4 & 74,7 \\
\hline humility & 6,1 & 3,4 \\
\hline the presence of the patron saint & 8,3 & 6,3 \\
\hline acquaintance with influential people & 33,7 & 37,9 \\
\hline the ability to adapt & 39,2 & 42,5 \\
\hline $\begin{array}{l}\text { knowledge and observance of } \\
\text { traditions and unwritten laws }\end{array}$ & 7,2 & 4,0 \\
\hline other & 3,3 & \\
\hline
\end{tabular}

Thus, such data on living standards, concerning various aspects of social life among pupils youth and students, lead to serious reflections, as they demonstrate the unduly small role played in this important process by such competent sources of information as teachers, teachers, doctors, school psychologists, social educators, social workers.

Thus, the dependent position of a person in the formally defined limits of the "teacher-child" system in a general education school, vocational education institutions dramatically reduces the child's personal significance for a professional socialist. And this limits the capabilities of the developing person to be fully represented in the minds of a referent adult or adult community. 
"The process of socialization reveals and constitutes the peculiar power of socializing adults over the child”, writes V.O. Vasyutinsky ${ }^{14}$, who "predetermine its development through joint activities ... support for internalizational and adaptive forms of socialization ... at the same time, these socializing adults restrict the individual in development, close other opportunities to him, restrain him in his own efforts".

The consistent implementation of the formal functional-role approach to organizing its interaction with the micro-institution of the institution forces the teacher to act within the limits of the norms of the system of relationships that spontaneously forms between pupils, between employees, between pupils and adults. They contribute to the establishment of such an informal structure of communities, the nature of which may directly contradict the educational goals.

Negative effects of the marginalization of the pedagogical community are particularly acute in localized groups. For example, in orphanages, boarding schools, and vocational-specialized boarding schools there is a fairly pronounced confrontation between polar strata, which practically does not reduce the intensity of communication between their representatives with each other. This becomes possible because in closed communities of this type daily close, although the confrontational contact of everyone with everyone is the norm of intragroup life. In such educational institutions, the informal rights and responsibilities of each of the intragroup strata are clearly defined in the unwritten set of rules and norms of "other life".

Despite the well-known features of the informal intragroup structure of closed communities, the common features of the intra-group "device" allow us to talk about the socio-psychological similarity of such groups. The complete concentration of informal power in the hands of a clear minority, discriminatory in its content and frankly antihuman forms of influence of this minority on the intragroup majority, "caste” by its nature, intragroup status differentiation, a high degree of personalization of the "elite" in the minds of the depersonalized major mass of the community is the main indicators of the life of groups of different localization ${ }^{15}$.

This requires consideration of the entire set of such communities as marginal as groups that can, under appropriate circumstances, turn into corporate groups with a pronounced asocial orientation.

\footnotetext{
${ }^{14}$ Васютинський В.О. Інтеракційна психологія влади. - К.: Вид-во Київ. славіст. ун-ту, 2005. - 492 с.

15 Кондратьев М. Ю. Социальная психология закрытых образовательных учреждений. - СПб.: Питер, 2005 - 628 с.
} 
It will be important to direct the socializing influence in such a way that, for example, to form personal responsibility, increase the self-esteem of a young person, her confidence in her own ability to achieve something significant or overcome something unnecessary.

\section{CONCLUSIONS}

The educational system is traditionally the leading institution of socialization and has specific features: the purposeful nature of the impact on the restoration of the existing social system (conservatism), the existence of a unified ideal model of socialization (unification), the temporality of influence, the existence of the corps of professional socializers.

Formation of the social picture of the world in the process of translating relevant for a certain historical period of knowledge is carried out in the system of interaction of the student with a professional socializer.

The pedagogical community represents specific institutional values rather formalized and to some extent anonymous, which determines the narrowing of the subjective significance of the educator for the pupil. The degree of subjective significance of the personality of the teacher, his reference for the child, the adolescent, the teenager distributes to him the range of variations of the picture of the world.

The main issues in the development of a particular problem are the active search for opportunities and ways of demarganizing the community or the individual, which involves a concentration of efforts to narrow the boundaries of the "marginal breakthrough", outlining the constructive direction of the development of a modern pedagogical community that can change the state of affairs in a marginal social situation.

The main source of information on issues of personal concern and concern for most teens, adolescents and young people are friends, peers, acquaintances, family members, and others like that. The second most powerful source of information is television, radio, periodicals. The third according to the rating (but with low indicators) is the teacher's source of information for schoolchildren, although it is he who has to play one of the most important roles in the life of a teenager, but with age his role naturally reduces in favor of special literature, which goes on to the fore in the student's period.

Unfortunately, the role of a professional socialist, educator in the process of informing on these issues is insignificant. 


\section{SUMMARY}

The signs of the traditionally leading institution of socialization are defined: conservatism, unification, limitation of influence over time, the existence of the corps of professional socializers. Formalized representation of specific institutional values by the pedagogical community causes the subjective significance of the teacher to narrow the pupil, his role in shaping the social picture of the child's world. It is emphasized the importance of a detailed study of the problem of marginalization, conditions and resources of the demarginalization of the pedagogical community and its separate segments.

Demifologization of views on the historical past, the loss of the mono-ideological conviction of youth causes aggravation of problems in the youth environment, its social disorientation, social passivity of youth, extreme manifestations of politicization or apolitical, radicalization and nonconformism in relation to the values of the majority, the priority of consumer orientations over creative ones. Some results of the research are summarized in order to determine the socio-cultural and sociopsychological portrait of modern Ukrainian youth through a mass survey in the southern and eastern regions of Ukraine, which allowed to outline the spectrum of the problem field of its life.

\section{REFERENCES}

1. Васютинський В.О. Інтеракційна психологія влади. - К.: Вид-во Київ. славіст. ун-ту, 2005. - 492 с.

2. Карамушка Л. М. Психологія освітнього менеджменту: Навч. посібник. - К.: Либідь, 2004. - 424 с.

3. Китаев-Смык Л.А. Психология стреса. - М.: Изд-во «Наука», 1983. $-368 \mathrm{c}$.

4. Климов Е.А. Психология профессионала. - М.: Педагогика, 1996. -125 c.

5. Кондратьев M. Ю. Социальная психология закрытых образовательных учреждений. - СПб.: Питер, 2005 - 628 с.

6. Кулик С.М. Психологічні проблеми професійної адаптації вчителів//Актуальні проблеми психології. Том 1.: Соціальна психологія. Психологія управління. Організаційна психологія / За ред. Максименка С.Д., Карамушки Л.М. - К.: Інститут психології ім. Г.С. Костюка АПН України. Частина 2, 2001. - С. 201-204.

7. Малхазов О.Р. Психологія праці: навч. посібник для студ. вузів / О.Р. Малхазов. - Київ : Центр учбової літ. (ЦУЛ), 2010. 206 с. : рис., табл. 
8. Организационная психология: Учебник (под общей редакцией А.Б. Леоновой) / А.Б. Леонова, М.М. Абдуллаева, Т.Ю. Базаров и др. - ИНФРА-М Москва, 2013. - 429 с.

9. Реан А.А., Баранов А.А. Факторы стрессоустойчивости учителей // Вопросы психологии, 1997. - № 1. - С. 45-54.

10. Словник іншомовних слів. К., 1975. С. 413.

11. Социология образования перед новыми вызовами («круглый стол») // СОЦИС. 2000. № 6. С. 65-66.

12. Татенко В.О. Соціально-психологічні проблеми реформування освіти: спроба системно-типологічного аналізу // Наукові студії із соціальної та політичної психології. - 2005. - № 10 (13). C. $15-35$.

13. Maslach, C., Jackson, S. E., Leiter, M. P. Maslach Burnout Inventory Manual (4 Edition). Palo Alto, California: Consulting Psychological Press, Inc., 1997. P. 46-71.

14. Mitina S.V. The factors of emotional burnout of the teacher of the higher educational institution. Psychological and pedagogical problems of modern specialist formation. Warsaw: ANAGRAM Publishing House, 2017. № 1. P. 34-37.

15. Park R.E. Human migration and the marginal man // Amerikan Journal of Sociology. Chicago, 1928. Vol. 33. № 6. P. 881-893.

\section{Information about the author:} Bielavina T. I. $\mathrm{PhD}$ in Psychology, Associate Professor at the Department of Psychology and Pedagogy of the Scientific and Humanitarian Institute of the V. I. Vernadsky Taurida National University 


\section{PSYCHOLOGICAL BASIS OF CREATIVE PERSONALITY DEVELOPMENT AT THE STAGE OF CHILDHOOD}

\section{Bila I. N.}

\section{INTRODUCTION}

The problem of children's creativity, the nature of its origin and development over several decades has been the subject of research by a number of scientists. The source of creativity is often considered as the result of solely internal forces and the potencies of a child. The formation of creative abilities in this case is reduced to a spontaneous moment which is uncontrollable. The most balanced, in our opinion, is the point of view on the existence of a source of children's creativity in life itself and the possibility of an active influence on its development.

Preschool age, without a doubt, is a favourable period for the development of an individual's creative inclinations, their manifestations in the fields of knowledge and artistic activity. After all, it is well known that most of the mental characteristics and processes, in particular, memory, thinking, perception, attention, imagination are in the stage of formation, change and development in children of this age. The creative potential of a child, his or her creative abilities are revealed and developed in the process of specially organized training and upbringing of a child, when the child is accepted and respected, and he or she, by acquiring and using own creative experience, is attracted to real creative affairs. Thanks to this, a kid learns to properly navigate the environment, increases creative abilities in various activities (playing, design, art, speech, etc.). It is amplification, and not forcing, of the child's mental development in the leading activities accompanied by an adult that contributes to the formation of the basis of a creative personality. It is important to believe in the child's abilities and capabilities and provide him or her with a developing living space.

\section{Prenatal period the world cognition}

Prenatal psychology (lat. pre - before, lat. peri - about, around, lat. natalis - referring to birth) - the science of the mental life of an unborn child or a just born one, studies the circumstances and patterns of human development in the early stages: prenatal, perinatal and neonatal phases 
of development, and their influence on all subsequent life. The prenatal period of development in the formation of an individual's personality, according to A. Bertin, is a period of both "missed opportunities" and a period of "great opportunities" .

Today in prenatal psychology in our country the most intensively studied are individual areas, in particular, the psychology of maternity (O.P. Proskurnyak, O.V. Tyunova, V.I. Shcherbanova, T.A. Sheludchenko, G.G. Phillipova, N.V. Yaremchuk, S.Y. Meshcheryakova) and the state of pregnancy, its physiological and psychological aspects (E.A. Sergiyenko, O.A. Sokolova, V.I. Kuznetsova, O.S. Kocharyan, G.N. Chumakova, Ye.G. Shchukina).

It is known that prenatal (intrauterine) development of a fetus includes its mental development, at this stage susceptibility, temperature and sensory sensitivity, perceptual and sensory-motor processes develop which underlie a child's psychics development. In the last months of pregnancy reception and motility are at a sufficient level of physiological and functional maturity to ensure adequate use of exteroceptive information and motor response after the moment of birth. The achievements of the last decades of raising premature babies indicate that, starting from 22 weeks, a child can successfully develop outside mother's body; all the forms of a baby's sensitivity and emotional experience of stimulation are formed.

These facts, as well as the success of genetics, allow us to discard the Aristotelian position about the new-born child as a tabula rasa ("clean board”), which was inculcated in the past ${ }^{2}$. The theory of prenatal evolution proclaims that the presence of neurons in the period of prenatal development is a kind of reserve that will be needed at subsequent stages of the development of civilization. If after birth the information received by neurons is simply remembered, then during the prenatal period it literally forms these cells. Experts believe that prenatal development should be stimulated by increasing the intensity of the flow of information that will "wake up" neurons and prevent them from atrophying. The earlier a child learns to use his or her neural reserves, the easier it will be for the child to get used to, adapt to the environment in which he or she will live ${ }^{3}$.

\footnotetext{
1 Бертин Андрэ Воспитание в утробе матери, или рассказ об упущенных возможностях / А. Бертин - Жизнь, Санкт-Петербург, 1991.

2 Батуев А.С. Возникновение психики в дородовой период: краткий обзор современных исследований / А.С. Батуев // Психол. журн. 2000. - Т.21. - № 6. - С. 51-56.

3 Бертин Андрэ Воспитание в утробе матери, или рассказ об упущенных возможностях / А. Бертин - Жизнь, Санкт-Петербург, 1991.
} 
The new-born baby has inborn perceptual equipment - not only the sense organs, but also neural circuits for their regulation, starting from the third month of life, when most of the embryo's body begins to feel tactile touches. By the third month of pregnancy also arises a taste perception. Every day, a baby drinks a certain amount of amniotic fluid in which he or she floats. When sweet glucose was added to its composition, the foetus drank more than usually, and when the solution was bitter - less. By the time of birth, the organs of taste and smell work to perfection. The ability to perceive odours is also important for the adaptation of new-borns to new, unusual conditions. It is proved that a new-born can distinguish the smell of breast milk from his mother from the smell of milk of another's woman. The hearing and the sense of equilibrium are also actively developing. At 8 weeks, the baby's inner ear is formed, then the external ear develops and the entire ear system is formed for up to 5 months. Lastly, visual sensations appear. By the end of the sixth month, all the senses function more or less well, they are able to inform the foetus about the things happening in the environment. On the 20-22nd week, the child moves away from the touch of the cold sensor of the ultrasound machine. Based on this, Franz Veldman, a doctor from Denmark, developed a method of communicating with the foetus - haptonomy - a contact through touch, which is used in the practice of prenatal education to improve the interaction of the mother with the child.

To date, scientists have already sufficiently studied the ability of the foetus to auditory perception, sounds differentiation, and even the presence of auditory memory has been proved. It has been noticed that the foetus "prefers" listening to classical music, opera arias, folk songs, ancient romances and does not tolerate loud sounds of rock music. Already at the 32-33rd week of development, a selective reaction to the proposed music program is observed. The works of Brahms, Bach and Beethoven act excitingly, cause foetal movement, while the melodies of Vivaldi and Tchaikovskyi, on the contrary, can calm down the child, and Chopin can tune to a quiet, "romantic" mood. The change of mother's emotional state while listening to any music or talking to someone causes a change in heart rate, breathing rhythm, her voice (it becomes tense, sad or, on the contrary, benevolent), as well as corresponding changes in hormonal background, etc. The foetus remembers the reaction of the mother's organism to this or that sound stimulus, and can react accordingly to it (with harsh sounds to lurk, with loud and unpleasant sounds for the mother - to increase motor activity), and after birth he or she can react to this very sound taking into account the intrauterine experience. 
It was experimentally proved that in utero a child is able to learn, and more intensively than any new-born, even in the case of a natural genius. Studies by American scientists have shown that just a ten-minute listening to Mozart's piano music increases the so-called IQ of a kid by 8-9 units on average ${ }^{4}$.

In addition to selective reaction to various musical works, the ability to memorize and recognize music, which arises under the influence of repetitive episodes of musical contexts, is intensively developing. In an interview with television, American conductor Boris Brott answered the question of where he learned to love music, as follows: "This love lived in me before birth." Familiarizing with certain works for the first time, he already knew the part of the violin before turning the page of the score. Brott could not explain the reason for this phenomenon. Once he mentioned about this in his mother's presence who was a cellist in the past. She looked at her old programs and found that her son knew by heart exactly those works that she was learning while pregnant ${ }^{5}$.

It is noticed that the most developed children are born in families where mothers dedicate pregnancy months to the disclosure of their own potential, engaging in music, artistic creation, singing, and drawing. At the same time, the child experiences positive emotions. Nothing stimulates the child's abilities and intelligence more than the pleasure of creative activity that a mother receives in the last stages of pregnancy. It was not by chance that in ancient times pregnant women were recommended to communicate more often with good people and surround themselves with everything beautiful.

Even for ancient civilizations, the significance of the period of pregnancy was absolutely inviolable truth. The Egyptians, Indians, Celts, Africans and many other nations developed a set of laws for mothers, couples and society as a whole, which provided the child with the best conditions for life and development. More than a thousand years ago, prenatal clinics existed in China, where expectant mothers spent a period of pregnancy surrounded by peace and beauty.

The intra-uterine period, according to Stanislav Grof, is the happiest, carefree period in a person's life. In the life of any person there are situations when, as a result of physical or mental distress, the need for security arises. Having taken the "foetal position", a person calms down,

\footnotetext{
${ }^{4}$ Медведева С. Развивающие игры для детей. От 20 недель беременности до года / C. Медведева. - M.: GELEOS Publishing House; Лэпитал Трейд Компани, 2010. - 265 с.

${ }^{5}$ Бертин Андрэ Воспитание в утробе матери, или рассказ об упущенных возможностях / А. Бертин - Жизнь, Санкт-Петербург, 1991.
} 
begins to feel comfortable. Some scientists attribute this behaviour to an unconscious need to return to the intrauterine state - a period when the sense of peace was stable ${ }^{6}$.

It has been proven that the emotional state of mother - positive harmony - has a positive effect on a child. It is achieved primarily while communicating with nature. Enjoying the beauty of nature, inhaling its aromas, rejoicing at the singing of birds, the murmur of the brook, the uniqueness of all natural phenomena, mother contributes to the development of special hormones that are transmitted to the baby by the circulatory system and stimulate his growth and development.

No less useful is reading poems about love, nature, fairy tales, myths, legends aloud and silently, visiting exhibitions, museums, art galleries. Contemplation of portraits, landscapes, still lifes, scenes from the life of people bring the mother, and through her the child, closer to learning the secrets and beauty of the world around. The quality of the emotional connection that exists between the mother and the child, according to psychologists and psychiatrists, is determined by the presence of a significant factor - the Love with which she bears a child; thoughts associated with his or her appearance; the wealth of communication that the mother shares with her child, all this affects the psychics of the foetus.

S. Freud also paid close attention to the events of the period of prenatal ontogenesis which impose a deep imprint on the whole future life of a person. To date, a wealth of evidence has been accumulated indicating that the mother's behaviour during pregnancy is responsible for such postnatal conditions as neurosis, anxiety, various allergies, mental retardation and other forms of pathology ${ }^{7}$.

The role of emotional bond, which plays the most important role along with sensory abilities in the development of the foetus in the womb, is confirmed by modern scientific research conducted by specialists in various fields. It is noticed that from the end of the third month the finger of the foetus is often found in his mouth. Finger sucking can be caused by a prolonged sad or anxious mother's state.

Joy, excitement, fear or anxiety affect the rhythm of her heartbeat, blood circulation and metabolism: when the mother is happy, the blood carries the hormones of joy - endorphins, when she is sad or worried -

\footnotetext{
6 Развитие личности ребенка от рождения до года / Сост. В.Н. Ильина. Екатеринбург: У-Фактория, 2003. - 304 с. (Серия «Психология детства»).

7 Батуев А.С. Возникновение психики в дородовой период: краткий обзор современных исследований / А. С. Батуев // Психол. журн. 2000. - Т.21. - № 6. - С. 51-56.
} 
stress hormones. The child also experiences the corresponding sensations (safety or danger). The little germ, of course, still unconsciously perceives these signals, but with all its self already feels how it is being treated - with joy or anxiety, calmness or fear. The mother's attitude, the place that the baby occupies in her heart, directly affects his growth, development, sense of his place in the world. The interrogation of five hundred women showed that almost one third of them never thought that she was carrying a child. The children, whom they gave birth, had nervous disorders more often. At an early age these children cried a lot more. They also experienced certain difficulties in the process of adaptation to life ${ }^{8}$.

It is known that even if in the early stages a woman thinks about the possibility of abortion and subsequently refuses from this thought; her child grows up lacking self-confidence. For no apparent reason, he or she feels needless, unloved. In the future, it is quite difficult for the child to find the way in this world, to cope with obstacles and reach some heights. In turn, children who are still in the womb fully receive the attention they need, grow self-confident. At the subconscious level, they have the idea that there are forces in this world that are ready to support them in any situation. They boldly go forward without fear of failure, and have more chances to reach their potential. Conscious, positive attitude to the foetus during pregnancy is necessary for the formation of a child's healthy psychics and optimistic life disposition.

The child focuses on the condition of the mother and subjective experiences through motion activity. This ability of the child suggests that the state of emotional comfort, in accordance with the optimum level, stimulation to maintain the level of excitation of the nervous system, turns to a status of need. Under the condition of insufficiency of this "additional" stimulation from the mother, the child increases his or her own activity. The need for movement is defined by L.I. Bozhovych, K. Rogers, A. Maslow as one of the child's basic needs ${ }^{9}$.

And although the level of stimulation of the child is regulated by his own activity, and the "background sensory world" can be separated from subjective experience with the stimulation that depends on one's own activity, the beneficial effect of contact with the mother on the development of premature babies and selectivity to maternal stimulation

\footnotetext{
8 Развитие личности ребенка от рождения до года / Сост. В.Н. Ильина. Екатеринбург: У-Фактория, 2003. - 304 с. (Серия «Психология детства»).

9 Филиппова Г.Г. Психология материнства: Учеб. пособие / Г.Г. Филиппова. - М.: Изд-во Института Психотерапии, 2002. - 240 с.
} 
of the new-born allows to suggest that the "sensory world of maternal stimuli" is the basis for the formation of the need for emotional comfort and perceptual activity. Positive maternal emotions cause increased growth, calm and growth of intelligence level of a foetus. Its deprivation and distress lead to low foetal weight, an increase in the percentage of mortality, and a decrease in cognitive development.

Modern views on the study of the foetus led to a series of spectacular studies that showed the decisive role of the enriched environment. It was discovered that prenatal stimulation causes an increase in motor abilities and properties of intelligence, which are preserved for years. A group of pregnant women who took part in prenatal intensive stimulation was studied in parallel with a carefully selected control group that did not participate in antenatal programs. Postnatal evaluation of both groups according to standard developmental tests showed a significant increase in motor development, visual skills, emotional statements and early speech in children with prenatal sensory stimulation ${ }^{10}$.

Early prenatal training plays an important role both in terms of the postnatal deployment of the genetic program and in the early stages of the infant's adaptation to a new environment. In the last trimester, foetal development is characterized by differentiation of phylogenetically new zones of the cortex, growth of the associative systems of the brain. This period is sensitive for the formation of the nervous system individual characteristics, the child's mental characteristics and even his or her capabilities (I.A. Arshavskyi, G.I. Polyakov) ${ }^{11}$. It is noticed that children whose parents speak to them from their birth usually develop speech earlier. In addition to intonation, children are able to assimilate a number of sound combinations unconsciously. Already at the 5th month a baby distinguishes the speech sounds that the mother utters, reacting to each of them with the contraction of certain muscles. Together with the development of hearing before the baby's birth his preparation for speech begins. As it is known, when a person is listening to speech or music, the muscles of his or her vocal apparatus contract absolutely imperceptibly when the heard sounds are repeated soundlessly. For a child preparing for life in the language world, listening to both speech and music is a good training. Modern specialists in prenatal development believe that it is better to start singing lullabies before the baby is born. The game

10 Батуев А.С. Возникновение психики в дородовой период: краткий обзор современных исследований / А.С. Батуев // Психол. журн. 2000. - Т.21. - № 6. - С. 51-56.

11 Филиппова Г.Г. Психология материнства: Учеб. пособие / Г.Г. Филиппова. - М.: Изд-во Института Психотерапии, 2002. - 240 с. 
interaction with the child should also include pamphlets and plaything, short rhymed stories that help the child to feel better the melody of the native language and its rhythm ${ }^{12}$. Some experts believe that in the framework of prenatal education, it is useful for children to give even foreign-language recordings to them for listening.

Prenatal development is based on the idea of providing the embryo, and then the fetus, with the best conditions and materials. The prenatal period of development is similar to the process of electroforming. If the expectant mother provides the child with the best physical material and qualitative information available on the sensory, emotional and mental levels, this will become a part of the natural process of developing the full potential, all the abilities laid in the ovicell for the successful socialization of the individual in the future.

\section{Genesis of a child's world perception}

From the first days of life, consciousness aims to build sensory psychic construction in the process of perception. In the course of subjectmanipulative activity a child forms a complex meaningful action that contributes to the emergence of an adequate, holistic image of the subject. "The longer and more productively the child creates, the more diligently her hands work, the more actively her speech, writing, thinking, memory, creative abilities develop," - V. Sukhomlinskyi emphasized and affirmed that "the origins of the creative abilities of children are on the tips of their fingers. From the fingers, figuratively speaking, come the finest streams that feed a source of creative thought ... The more skill a child's hand has, the smarter the child is ... Children become researchers, the thought is constantly connected with the most delicate labour operations of hands, and this connection (the hand develops the brain) plays a truly saving role for those who experience big difficulties in learning and who would be doomed if there were not a special focus of training to develop the mind ...”13.

It is known that at an early age, children actively use the taste, tactile and olfactory receptors in the development of the world, they pull everything to the mouth, which is phylogenetically determined by an important receptor part of the body. It is designed to interact with the outside world, aimed at replenishing the body's resources, providing it with food. It is the child's mouth that participates in the construction of the first mental images and even of the representational models of the

\footnotetext{
${ }^{12}$ Медведева С. Развивающие игры для детей. От 20 недель беременности до года / C. Медведева. - M.: GELEOS Publishing House; Лэпитал Трейд Компани, 2010. - 265 с.

13 Сухомлинський В.О. Вибрані твори в 5т. - К: Рад.школа, 1997.
} 
objects surrounding him. Not only the taste, tactile and olfactory receptors of the oral cavity and nose are involved in building such representation models, but also complex intraceptive sensitivity, including kinaesthetic, proprioceptive, and vestibular sensitivity. The object is investigated in various aspects, including its resistance to pressure of the jaws, sucking lips and tongue, rolling in the mouth, etc. As a result, not only gustatory and olfactory sensations are formed, but also understanding of such properties of an object as softness, toughness, smoothness, elasticity, hardness, juiciness or dryness, etc., arises. All of them collectively participate in the formation of the sensory model-representation of the object, which already includes its visual images ${ }^{14}$.

From the moment of birth, a child gains experience in the process of activity, the development situations of which are very diverse and numerous. The diverse experience of private interactions with various aspects of reality is not just copied in the process of its reflection by the child, but is also transformed. There is a selection of experience, its practical interpretation, synthesis, that is, the construction of the "image

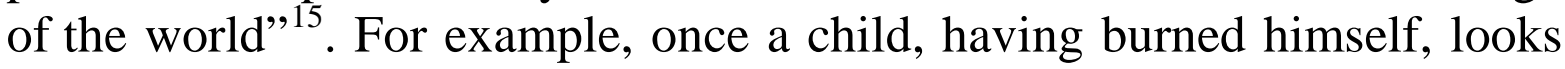
at the light of a candle in a different way, it no longer attracts her, but, on the contrary, literally pushes him or her away. Vision is imbued with some content that determines the function of the object in the picture of the world and the existence of the subject in it. The value of sensory impressions of a preschool child develops in the process of his or her constant interaction with the surrounding reality.

From the first days of life an important factor in this process is represented by adults, who do not only explain the meaning of sensory impressions, but also give the child practical information about the properties of objects, methods of action with them, raise the child's interest by attraction, interest to actions with objects. Under the guidance of an adult, in the course of the manipulative actions of examining an object, formed are the skills that constitute a system of operations in which various groups of analysers participate. Survey operations are encouraged first by the novelty of the object itself, and then, due to the peculiarities of the orienting reaction, they can arise as a reaction to a change in the object - manipulation is transformed into an action aimed at

14 Поляков С.Э. Феноменология психических репрезентаций / С.Э. Поляков - СПб.: Питер, 2011. - C. 273.

${ }^{15}$ Новоселова С.Л. Генетически ранние формы мышления: Учеб. Пособие / С.Л. Новоселова. 3-е изд. - М.: Издательство Московского психолого-социального института: Воронеж: Издательство НПО «МОДЭК», 2010. - 352 с. - (Серия «Библиотека психолога»). 
identifying a new thing in the subject, that is, at an indicative action. The child familiarizes with the properties of the object and begins to act in the light of these properties.

Gradually, the child learns the right (normative) actions with objects: a ball is rolled, a car is pushed, a doll is laid on the bed, the cubes are set, put, arranged or spread, the pyramid is assembled and disassembled, the rings are strung. The child acts with toys to get some interesting effect, to learn new sounds: rattle clattering, ball rolling, toy falling, sparkling, noise, etc. An adult shows the necessary methods of action with objects, the child begins to experiment, placing the object in different positions, combining it with others, that is, investigating them, which contributes to a deeper knowledge of the objects properties ${ }^{16}$.

The experience of the subject activity is not just accumulated; it undergoes quantitative and qualitative changes. The first stage is characterized by subject-specific manipulations that depend on the natural functional capabilities of the infant's hands, which, through survey operations, turn into indicative actions. At the second stage, on the basis of tentative actions, subject-specific operations are formed. The third stage in the development of substantive activities is associated with the emergence of subject-specific actions. The fourth stage - actions become subject-mediated. Toys give an opportunity to establish oneself in the norm of substantive action given by the cultural-historical process, because of the variability of actions, which is an important moment for understanding the unity of the productive norm and the creative moment in the activity.

Gradually adopting perceptual experience through practical use in the course of repeated actions, similar to those proposed by adults, children enrich their cognitive experience through observation, experimentation with objects, their properties and functionality. The result of this child's activity is the formation of his or her vision of the world. The experience of activity is constantly accumulated and enriched, ensuring that the reflection of reality is reflected adequately in the mental image of the world and in the actions of the child mediated by the appropriate level of his or her psychic reflection. Thinking, mediated by the generalized experience of objective activity, becomes a substantive mechanism of its development. That is, the sensory experience of a child (visual, motor, auditory, etc.) is not isolated from the processes of thinking, speech, but is

\footnotetext{
${ }^{16}$ Новоселова С.Л. Генетически ранние формы мышления: Учеб. Пособие / С.Л. Новоселова. 3-е изд. - М.: Издательство Московского психолого-социального института: Воронеж: Издательство НПО «МОДЭК», 2010. - 352 с. - (Серия «Библиотека психолога»).
} 
the step in their formation. The adult's word captures the sensory experience acquired by the child and enriches it; it rationalizes and individualizes the act of examining the subject, directs it to make perceived the parts and sides which are important and less accessible to perception. The word enriches, brings in something that sensory experience does not give and the child himself cannot distinguish in the object or phenomenon. Thus, it raises perceptions to a new, higher level ${ }^{17}$.

Mastering touch standards, developing perceptual actions, creating visual models, imagination images - all this is the basis for developing a child's creativity. L.S Vygotskyi noted that if we want to have sufficiently strong foundations for the child's creative activity, it is necessary to expand his or her experience in every possible way. The more the child saw, heard and experienced, the more he or she knows and learned, the more elements of reality possesses, the more meaningful and productive, with all other things being equal, his or her activity will be. And this demonstrates the need for the development of experience, a system of knowledge and skills, as an important basis for the development of creative activity and creative personality traits.

Formation of children's ideas about the properties of objects: shape, colour, size, position in space is necessary for their full perception of the surrounding world. Gradually, perception turns into an independent cognitive process, and on its basis an important quality is formed observation skill. Observation skill, in our understanding, is purposeful perception, a fusion of attention and thinking, a complex cognitive process in which the unity of the sensual and rational is manifested. Observation skill includes: the ability to see objects and phenomena from different angles; to notice all the characteristics, to highlight the essential; to recognize typical features in objects; to navigate the environment properly. On the basis of the joint activity of the analysers, thanks to the word of an adult, children form specific knowledge, develop thinking, speech. The child, on his own initiative, notices new aspects and specific features in the subject. His or her perception and attention are analytical in nature - the child does not just fix the object but analyses it, compares, evaluates, and finds things in common with others. Throughout all preschool period, there are changes, from simple attempts to examine and feel till the desire to examine and describe the subject more systematically and consistently, distinguishing the most noticeable features.

17 Мухина В.С. Детская психология / В.С. Мухина - М.: ООО Апрель Пресс, ЗАО Изд-во ЭКСМО-Пресс, 1999. - С. 283-296. 
The organization of children's observations of the surrounding life, the finding of what can be reflected in the results of their activities, according to N.O. Vetlugina, is an important pedagogical condition for the formation of creativity. The development of the methods of "attentive listening", "peering" into the figurative world of art, into the sounds and colours of the natural and objective world is the way in which the child's creativity develops ${ }^{18}$.

It is proven that in direct communication with nature, along with observation skill cognitive activity develops. The pronounced cognitive need is the most common characteristic of creative potential and the main component which tends to develop ${ }^{19}$.

The development of curiosity in children occurs in connection with their acquisition of the ability to find the essential attributes of objects and establish relationships. The more analysers are involved in perception, the more accurate, richer, brighter and more meaningful is the presentation. In everyday life, during walks, in games and work activities, children accumulate sensory experience from the influence of objects and natural phenomena on them.

According to scientists, observation, the ability to view objects simultaneously from two points of view is a very important component of a child's mental development. To the main indicators of the development of observation they refer:

1. The child's ability to focus on the task, follow the instructions.

2. Completeness of observations - the allocation of parts, the characteristic properties, actions and states of the object in accordance with the task.

3. Accuracy of observation, ability to notice inconspicuous components (shades, details of form, parts structure, etc.).

4. Conformity to plan, a determined sequence of viewing objects.

5. Understanding or interpreting previous experience in the light of the previous one and based on the existing knowledge.

6 . The degree of independence in the performance of tasks ${ }^{20}$.

The development of observation skill in children is manifested in the improvement of the analysis and synthesis of perceived objects, the identification of their low-profile features, the increase in the accuracy

${ }^{18}$ Художественное творчество в детском саду / Под ред. Н.А. Ветлугиной. - М. Просвещение, 1974. $-170 \mathrm{c}$

${ }^{19}$ Матюшкин А.М. Концепция творческой одаренности // Вопросы психологии. - 1989. № 6. C. 29-33.

${ }^{20}$ Ратанова Т.А. Диагностика умственных способностей детей. М.: Московский психологосоциальный институт: Флинта, 2003. - С. 92. 
of the verbal description, and the formation of the mindset for targeted observation. Observation skill and the various types of sensitivity that compose it, develop successfully when children perform tasks that require an independent knowledge obtaining, controlled by a pedagogue's word, about the appearance of objects, their shape, colours, spatial distribution, and other features. Good exercises for observation are the consideration of objects at a distance, with insufficient light of them, verbal descriptions of natural phenomena, landscapes, the appearance of people, their artistic images. Work in the nature, conducting experiments, excursions, drawing classes provide many opportunities for various observations that enrich the memory of children with specific images needed for the development of various abilities.

For full-scale children's perception of the surrounding world, it is important to form in them an idea of the properties of objects on various grounds using different analysers, namely: colours, shades which are perceived by means of vision; form (sight, motor-muscular actions, touch) size (sight, hearing, touch, motor-muscular actions); sounds, noise (hearing), correlation in space (vision, hearing) weight (vision, motor and muscular actions); surface properties: smoothness, roughness, elasticity; rhythm (sight, hearing, touch); movement of the object: direction, speed, route; name of the details of the object, etc. ${ }^{21}$

Preschool age is a period of rapid accumulation by the child of the experience and knowledge that underlies the creative activity. For the emergence of the pre-schooler's idea, vivid impressions are necessary, certain representations of which originate from the broad objective and natural world, social phenomena, literature, and various activities. But the children's perception of the world is superficial in most cases. That is why it is important to fill the lives of children with impressions, create conditions for a deeper mastering of the surrounding, form the ability to see the characteristic features of objects, phenomena, develop the observation skill of pre-schoolers.

\section{Phenomenology of children's creativity}

Preschool age is the period of development of the creative inclinations of an individual. A preschool child, realizing a plan in a productive activity, feels free; he or she is not constrained by experience, knowledge, not limited to prohibitions that do not allow operating freely with objects, materials, and the like. A free movement of thought outside

\footnotetext{
${ }^{21}$ Біла І.М. Уроки в природі: Методичний посібник. - Кам’янець-Подільський, 2005. Ч. 1. - С. 13.
} 
the known helps to find an unexpected solution. The emergence of children's unexpected comparisons and generalizations, original thoughts, perhaps in a certain way is explained by the lack of assimilated methods of analysis, ready-made stamps, and the novelty of their own mental work. All this, on the one hand, causes significant shortcomings in the nature of children's creativity, on the other - gives it importance and advantages over the creativity of an adult.

While developing the concept of the child's intellectual development, J. Piaget emphasized the role of imitation in the development of intellectual abilities: imitation of an adult is a special form of motivation that is not related to meeting organic needs, and is a source of initiative and development of not only intelligence, but also a creative ability ${ }^{22}$.

The presence of a sample of creative behaviour of a meaningful adult, the importance of examples of imitation for a child was emphasized by R. Sternberg: "Creative abilities do not develop when a teacher or parents tell children about the need for their development, but when adults show them how to do it" 23 .

Creativity, and in particular children's creativity, can hardly exist without models, without imitation, without reference points, without the fact that "it is already frozen once and for all" in certain norms ${ }^{24}$. Thus, the evolution of living organisms in general by the evolution of reproduction is a transformation. Human ontogenesis, like phylogenesis, invariably repeats this path of development - from imitation to transformation, from transformation by trial and error to transformation by the method of forecasting and accurate calculation; otherwise, from reproduction to partial creativity, from partial to full creativity. Therefore, the pedagogical forecast of the development of cognitive activity, the creative activity of children must accurately calculate its transition from the reproductive level to the reproductive-creative level, from the reproductive-creative to the creative level.

On the other hand, considering creativity through the prism of the trajectory of its development, its phylogenesis (general development), one should single out the characteristic features of the creative activity of preschoolers: its subjective aspects, product and conditions in which the creative process takes place.

\footnotetext{
${ }^{22}$ Пиаже Ж. Речь и мышление ребенка / Ж. Пиаже - СПб.: Речь, 1997. - 256 с.

23 Диагностика и формирование креативности у детей в процессе учебной деятельности / под ред. Г. В. Ожигановой // Психол. журнал № 2. - 2001. - Т. 22. - С. 75-85.

${ }^{24}$ Кульчицкая Е.И. Сирень одаренности в саду творчества / Е.И. Кульчицкая, В. А. Моляко. Житомир: Вид-во ЖДУ ім. І. Франка, 2008. - С. 243.
} 
Children make their own discoveries and create an interesting, sometimes original product in the form of a picture, a design, a poem, etc. (N.O. Vetlugina, M.M. Poddyakov, K.I. Chukovskyi, etc.). Subjectivity of the novelty of discoveries and product is an important feature of children's creativity.

Children's creativity should be understood as the creation by a child of a subjectively new (significant for him or her) product - drawing, design, games, stories, creation of previously unknown details which characterize the created image in a new way: various versions of images, situations, movements, characteristics of characters, other actions; the use of previously learned methods of depiction or means of expression in a new situation; display of initiative in everything.

When drawing, cutting and constructing, the child creates something that is subjectively valuable, new for him but has no panhuman novelty and value. At the same time, the process of creating a product itself is of paramount importance for the child. The child's activities are characterized by emotionality, the desire to seek and repeatedly test various solutions and receive special pleasure from this, sometimes significantly bigger than from achieving the final result (O.V. Zaporozhets, L.A. Paramonova, M.M. Poddyakov and others).

For an adult, the beginning of solving a problem (its awareness, the search for approaches) is a difficult and painful process, which sometimes leads to despair. The child does not experience such difficulties (unless, of course, an adult puts forward strict requirements). He or she easily and, above all, practically begins to act tentatively, sometimes even not quite meaningfully, and this activity, gradually acquiring a greater focus, captures by the search and even gives a positive result (L.O. Paramonova, M.M. Poddyakov, G.V. Uradovskych) ${ }^{25}$.

The essential characteristic of children's creativity is the absence of internal barriers that give rise to restraint and make creativity more difficult. It would be wrong to say that children do not have self-control. It exists, but it is aimed at the process of the game - creativity, and not at the quality of the creative product. A pre-schooler does not need an internal critic, since his work is not aimed at creating a social product, it is not focused on the product as an embodiment of the idea ${ }^{26}$.

In general, pre-schoolers' creative activity and creative potential can be analyzed by the following three groups of indicators:

${ }^{25}$ Парамонова Л.А. Теория и методика творческого конструирования в детском саду: учеб. пособ. / Л.А. Парамонова - М.: Академия, 2002. - С. 8.

${ }^{26}$ Левин А.А. Воспитание творчества / А.А. Левин. - М.: Знание, 1977. - 64 с. 
1) The children's attitude to creativity: their passion, the ability to "enter" the imaginary circumstances, conditional situations, sincerity of experiences;

2) The quality of the ways of creative actions: the speed of reactions, resourcefulness, the combination of familiar elements into new combinations, the originality of the methods of actions;

3) The product quality: the selection of characteristic features, objects, life phenomena, their reflection in creative activity ${ }^{27}$.

The child's creativity as his individual property is manifested in the ability to abandon stereotypical ways of thinking in the course of accomplishing any tasks (playing, everyday, educational, social and moral ones), creating a product that is new in content, original, based on non-standard "vision" of new opportunities in the known thing. Such a rejection of stereotypes, in turn, leads to the production of a large number of ideas.

Focusing on the importance of creating conditions for the development of cognitive motives and creative activity it is necessary to emphasize the role of an adult who supports and directs the pre-schooler's need for new impressions and social contacts, the desire to experiment actively, to transform. The implementation of research activity provides the child with the discovery of the world, the transformation of the unknown into the known, gives rise to creative images.

To encourage children to cognitive activity, creative activity, it is important to evaluate properly the children's achievements, not to interrupt the creative process, refrain from negative evaluations, accept the approval of pupils without abusing critical comments; create situations of free communication, exchange of thoughts. The steady positive atmosphere and the emotional appeal of the classroom encourages children to boldly submit their own ideas, to express emotions, and to promote the formation of creativity.

The success of the children's creative activity is associated with the need to create an atmosphere of complete success of each participant according to his or her capabilities and desires. In an environment characterized by a lack of criticism, evaluation, and stress, children are much better able to cope with creative and intellectual tasks. Simultaneously an adult is a senior partner who supports the child, ensures the success of his or her activities. He organizes a learning situation in a special way (multi-option and unassisted formulation of the

27 Художественное творчество в детском саду / Под ред. Н.А. Ветлугиной. - М. Просвещение, 1974. $-170 \mathrm{c}$. 
problem by a child in which he or she is interested; support for any creative initiative, absence of criticism of unsuccessful creative attempts; emotional contact with children), which allows the creation of inner motivation in children's creative activities, contributes to their creative self-expression and the development of creative skills.

\section{CONCLUSIONS}

Toddler and preschool age is the most sensitive period in the development of creativity, and on the things nurtured in this period will largely depend whether the child, in the perception and evaluation of the events, phenomena of the external world, will be guided with stereotypes and patterns, or will be able to produce his own means of problem setting and resolving and create. A creative child, a creative person are the result of the whole way of life in the prenatal and preschool period of development, the result of communication and joint activity with adults, the result of one's own activity. An important condition for encouraging children's creative activity is the creation of a developing environment, which contributes to the intensification of thinking, the development of sensory experience, perceptual actions, creative observation skill, and serves as a condition for aestheticizing creative activity. Creating a developing living space or environment means providing a set of conditions, an atmosphere which is most favourable for the progressive development of the child's consciousness and behaviour which feeds his or her natural forces, promotes the realization of potential, enriches with knowledge, positively influences the development of personal experience, forms realistic images of the world and of his own "Self" which are useful for harmonious, creative development of the child.

\section{SUMMARY}

The chapter analyses the prerequisites for the formation of a personality at the childhood stage. The crucial importance of the prenatal period is noted, and factors that stimulate mental development during all phases of preschool childhood and the genesis of a child's worldview are described. The role of the developing environment, the formation of perceptual experience, the presence of a significant sample of an adult, meaningful communication and socialization are emphasized. The signs of children's creativity and the necessary conditions for its activation are listed. 


\section{REFERENCES}

1. Батуев А.С. Возникновение психики в дородовой период: краткий обзор современных исследований / А.С. Батуев // Психол. журн. 2000. - Т. 21. - № 6. - С. 51-56.

2. Бертин Андрэ Воспитание в утробе матери, или рассказ об упущенных возможностях / А. Бертин - Жизнь, Санкт-Петербург, 1991.

3. Біла I.М. Уроки в природі / І.М. Біла // Методичний посібник. - Камянець-Подільський, 2005. Ч. 1. - 80 с.

4. Диагностика и формирование креативности у детей в процессе учебной деятельности / под ред. Г.В. Ожигановой // Психол. журнал № 2. - 2001. - Т. 22. - С. 75-85.

5. Кульчицкая Е.И. Сирень одаренности в саду творчества / Е.И. Кульчицкая, В.А. Моляко. - Житомир: Вид-во ЖДУ ім. І. Франка, 2008. - 316 с.

6. Левин А.А. Воспитание творчества / А.А. Левин. - М.: Знание, 1977. - $64 \mathrm{c}$.

7. Матюшкин А.М. Концепция творческой одаренности // Вопросы психологии. - 1989. № 6. - С. 29-33.

8. Медведева С. Развивающие игры для детей. От 20 недель беременности до года / С. Медведева. - M.: GELEOS Publishing House; Лэпитал Трейд Компани, 2010. - 265 с.

9. Мухина В.С. Детская психология / В.С. Мухина - М.: ООО Апрель Пресс, ЗАО Изд-во ЭКСМО-Пресс, 1999. - С. 283-296.

10. Новоселова С.Л. Генетически ранние формы мышления: Учеб. Пособие / С.Л. Новоселова. - 3-е изд. - М.: Издательство Московского психолого-социального института: Воронеж: Издательство НПО «МОДЭК», 2010. - 352 с. - (Серия «Библиотека психолога»).

11. Парамонова Л.А. Теория и методика творческого конструирования в детском саду: учеб. пособ. / Л.А. Парамонова М.: Академия, 2002. - 192 с.

12. Пиаже Ж. Речь и мышление ребенка / Ж. Пиаже СПб.: Речь, 1997. - 256 с

13. Поляков С.Э. Феноменология психических репрезентаций / С.Э. Поляков - СПб.: Питер, 2011. - 688 с.

14. Развитие личности ребенка от рождения до года / Сост. В.Н. Ильина. Екатеринбург: У-Фактория, 2003. - 304 с. (Серия «Психология детства»). 
15. Ратанова Т.А. Диагностика умственных способностей детей. М.: Московский психолого-социальный институт: Флинта, 2003. $-168 \mathrm{c}$.

16. Сухомлинський В.О. Вибрані твори в 5 т. - К: Рад. школа, 1997.

17. Филиппова Г.Г. Психология материнства: Учеб. пособие / Г.Г. Филиппова. - М.: Изд-во Института Психотерапии, 2002. - 240 с.

18. Художественное творчество в детском саду / Под ред. Н.А. Ветлугиной. - М. Просвещение, 1974. - 170 с.

Information about the author: Bila I. N.

Doctor of Psychological Sciences, Professor, Scientific Secretary at the Department of Psychology

Age Physiology and Defectology of the National Academy of Pedagogical Sciences of Ukraine 52a, Sichovykh Striltsiv str., Kyiv, 04053, Ukraine 


\section{GENDER APPROACH AS A NECESSARY CONDITION FOR FORMING GENDER COMPETENCE OF STUDENTS' YOUTH}

\section{Kostina T. O.}

\section{INTRODUCTION}

The situation in Ukraine today is the time of the deployment and implementation of reforms in various spheres of socio-economic interaction. Reforms have also affected education, including higher education. Any reforms mean changes that are actually reflected in the very word ("reform" from lat. "Transform", "change"). The reformation involves changing the outdated forms and creating new ones, which at the state level should be approved by law.

During the implementation of reforms, there is always a process of analyzing what is now and the desire to change the situation for the better. That is, reform is a change aimed at achieving the best result in the future. And this result should be better than the one available in the present situation.

Particular importance of reforming the education system should take place on a gender issue. Reform should always keep a gender perspective. Not just a gender, but always a gender. Without taking into account the gender perspective, we will not be able to be sure that the reforms are in the right direction. Be sure that every citizen/citizen has access to the necessary resources, including access to education.

In spite of significant progress in gender equality, unfortunately, it has not yet been achieved in any country. That is why this issue is relevant and needs further implementation.

The urgent issue today is the introduction of a gender-based approach to working with young people, especially in the context of higher education institutions. Because it is precisely in these institutions that the formation of a personality as a professional takes place, the acquisition of relevant knowledge and competencies. In our opinion, today, both for Ukraine and for the whole world, the formation of gender competence is of particular importance; the gender competence is especially important for young people who are educated in higher education institutions. 
Gender competence is defined as the socio-psychological characteristics of a person, which allows him to be effective in the system of interpersonal interaction. A successful professional is a gendercompetent professional. That is why the introduction of a gender-based approach to working with youth (including in the system of institutions of higher education) is extremely necessary.

It is the relevance of this issue for the pedagogical and psychological science of our day that predetermined our scientific search. The results of the theoretical analysis are presented in this paper.

\section{The main characteristics of the gender approach}

The gender approach is an approach that takes into account the needs of different categories of the population. This is an approach that allows for the observance of democratic values and priorities (equity, representation in a society in positions that have an impact on the adoption of important decisions for the community, etc.).

Women and men must have the same opportunities for shaping society and their lives. This involves overcoming discrimination and structural inequality in access to resources, opportunities and services.

The gender approach is not just a "theoretical" issue, which can be met by having a series of meetings, and discussions, and putting a point at that, to pretend that the issue has been resolved.

Of particular importance is the gender approach in the system of work with young people, in particular, student youth. Today it is one of the topical issues of great theoretical and applied significance for modern psychology and pedagogy. Psychology should determine the essence and content of the phenomenon, pedagogy should help in the implementation and dissemination of information to the target audience. Because any systemic changes will not be possible without their implementation at the state level. That is why the higher education system needs training courses, trainings, etc., which would help young people go beyond the established gender stereotypes.

A gender approach is access to the benefits and resources of society, an awareness of the different needs of people. It should be remembered that equality is not always an equality. People can have different set opportunities to realize themselves and their potential. The task of society is to take into account the peculiarities of a person and to help him/her in realizing his/her ability to be an active participant in society (the issue of inclusion) (see Fig. 1). 
That is why, taking into account the gender perspective is always taking into account the different needs of boys and girls, men and women. This means taking into account other inter-sectional factors (age, place of residence, level of education, etc.).

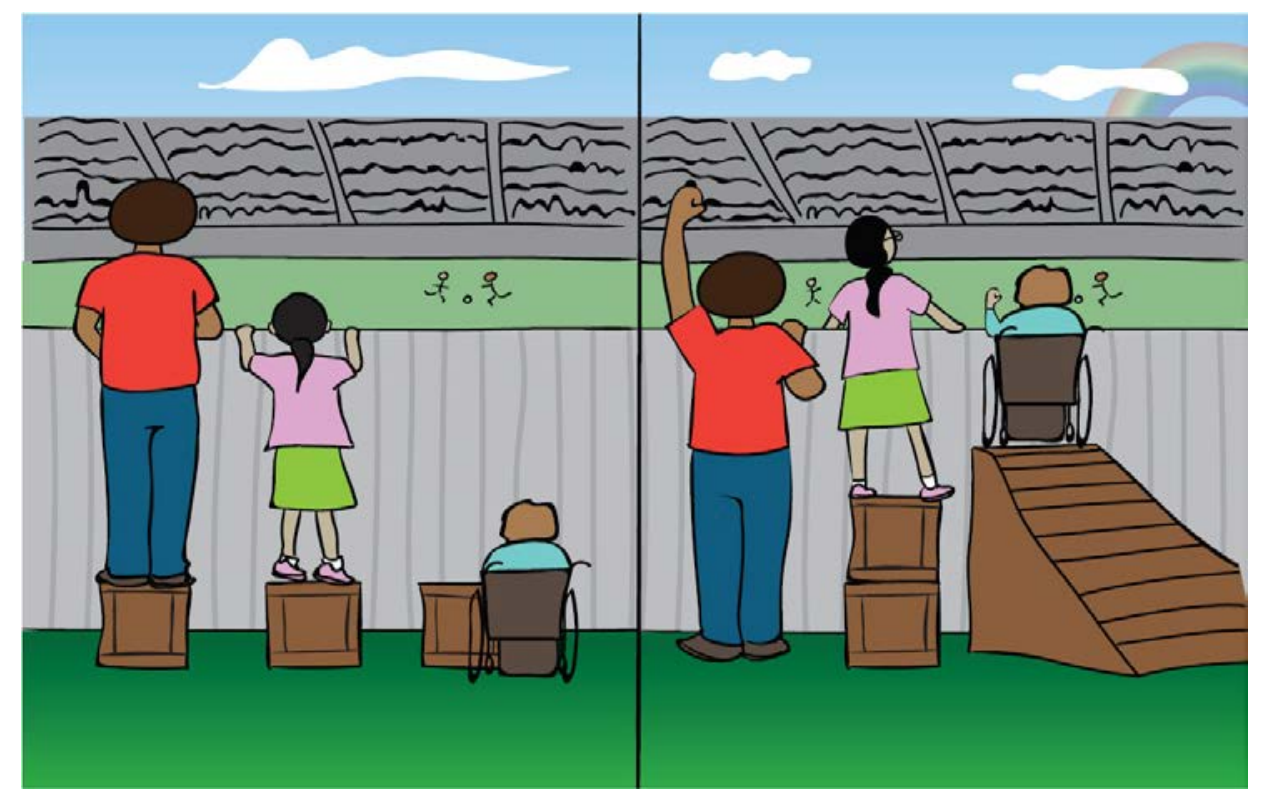

\section{Fig. 1. Gender approach: taking into account equity (equal rights) in access to resources}

The goal of the gender approach is to provide an opportunity for the realization of equality, when everyone has the opportunity to access their needs and exercise their rights and freedoms.

Of particular importance is the introduction of a gender approach to the education system. Because educational institutions are the place where the next generation is forming, which will change the society. And on the basis of which values and principles will be maintained the new generation will depend on which way our country will go. So, in order for our state to adhere to the principles of democracy, we must work with the younger generations.

If we talk about the gender perspective in Ukraine, then it needs many more points to be realized. In terms of legislation, gender equality is declared in Ukraine. However, reality does not always correspond to what is written.

That is why we are talking about the need to involve young people in the implementation of the gender approach. The increase, which reduces the impact of social (gender-specific) stereotypes and the expansion of social roles, will contribute to the formation of an individual that 
promotes positive changes in society and understands the need for social responsibility to different groups of the population.

Today in our country there are normative legal acts for ensuring gender equality:

- The Constitution of Ukraine (Articles 3.21, 24, 51);

- Law of Ukraine "On ensuring equal rights and opportunities for women and men";

- Decree of the President of Ukraine "On improving the work of central and local authorities to ensure equal rights and opportunities for women and men";

- Order of the Ministry of Education and Science "On the implementation of the principles of gender equality in education";

- Law of Ukraine "On Principles of Prevention and Counteraction of Discrimination in Ukraine";

- Law of Ukraine "On Prevention of Family Violence";

- Law of Ukraine "On Combating Trafficking in Human Beings".

We cite article 24 of the Constitution of Ukraine: "Equality of rights of women and men is ensured by: granting women equal opportunities with men in public-political and cultural activities, in obtaining education and training, in work and remuneration for it; special measures on health and safety of women, establishment of pension privileges; creating conditions that enable women to combine work with motherhood; legal protection, material and moral support for motherhood and childhood, including the provision of paid holidays and other benefits to pregnant women and mothers" ${ }^{1}$. As we can see, equality of rights of women and men is declared at the level of the basic law of Ukraine.

It should be noted that the state mechanism for ensuring gender equality is a system of interconnected state institutions whose competence and activities are aimed at implementing gender strategies and consolidating gender equality in real life in society. These include:

- Ministry of Social Policy of Ukraine - specially authorized central executive authority on equal rights and opportunities for women and men;

- Vice Prime Minister for European and Euro-Atlantic integration.

If we are talking about Ukraine's desire to join the EU, then it is impossible to take into account the issue of gender equality. This means that the gender approach is not only interaction within the state (internal aspect), but also interaction between states (external aspect).

\footnotetext{
${ }^{1}$ Конституція України. URL: D1\%80 (дата звернення: 19.06.2019).
} 
The introduction of changes requires an understanding of what this is accomplishing (goal, end result). Those (those) who have the right and desire to introduce these changes. And those (those) who, in fact, will implement the "on the ground" reforms.

If we are talking about the right to reform, we have to reach the level of legislative power and the legislative process - the procedure for adopting a law consisting of certain stages. These stages are sufficiently independent, logically completed stages and organizational and technical actions.

In Ukraine, the legislative process can be divided into several stages:

The pre-design stage is a legislative initiative, that is, the introduction of a draft law into a legislative body, carried out officially by certain bodies and individuals. Draft laws are submitted together with an explanatory memorandum, which should justify the necessity of drafting or passing the law.

The project stage involves the implementation of a whole series of works:

1) making a decision on drafting a bill, including an appropriate proposal in the plan of legislative works;

2) commissioning a draft law for certain bodies;

3) elaboration of the bill and its previous expeetitis;

4) introduction of the bill in the legislative body, adoption of it for consideration;

5) discussion of the bill and its approval.

The stage of the adoption of the law is the vote on the adoption of the law and the corresponding resolution on the enactment of the law.

The certifying stage is the sanctioning (signing) of the law by the head of state in the terms established by the constitution.

As we see, the implementation of changes in the legal field requires considerable effort. That is why we emphasize that the laws already have to work. They should be not only on paper but also be real. Such that they feel the citizens of the country. The question arises of "inventing" mechanisms that would force the law to work. Such levers of influence today are public organizations that embody active civil status.

However, in order to consciously approach such an important issue as a gender-based approach, it is not necessary to be a representative of a public organization. It is necessary to simply remember that each of us is a bearer of culture and there is someone else's role model (an example) that will be imitated by others (first of all, young people). 
This means personal responsibility for the actions (or inaction) that we implement every day in our lives.

Implementing a gender-based approach at the level of an individual means:

- see the gender perspective;

- do not increase inequality (discriminatory statements, follow stereotypes, disregard for human capabilities and potential);

- promote gender equality (gender balance: promotion of women to leadership positions, quotas, etc.);

- support gender advisers (invite them to conduct trainings and assess the gender balance in the institution);

- not only women (for example, "permission" to men for the manifestation of emotions, which today in our society, is often tattooed specifically for male representatives).

Gender (non) equality is structural/collective issues, but they also require commitment and the choice of an individual. Already, by our actions, words, actions we either increase gender inequality, or, on the contrary, we are making the phenomena of gender discrimination and inequality less. Gender equality is also the choice of an individual.

Think about what you can do to support gender equality as:

- a partner;

- mother/father;

- professional;

- boss;

- employee;

- service provider;

- role model.

Let's note that the gender approach is an instrument. However, it can not be implemented outside education/awareness of people about what gender equality is and how to combat gender discrimination. To do this, you need to know and understand unconscious bias (stereotypes) that prevent people from understanding the importance of gender equality. It is necessary to inform that gender equality is a win for everyone. This is not the struggle of women against men, it is not a loss of the position of men.

Gender equality is an opportunity to live in a better society, which gives everyone (taking into account her / his needs) access to resources. That is why we emphasize that there should be an educational activity that 
will help the younger generation to rethink the established patterns that they have learned in the process of maturing.

One of the easiest ways to test the established patterns of "feminine/ male" can be seen on the example of distributing toys and goods for children in children's stores (see Fig. 2). This picture shows how strong the influence of social stereotypes is on what the baby will play and what he/she will wear.

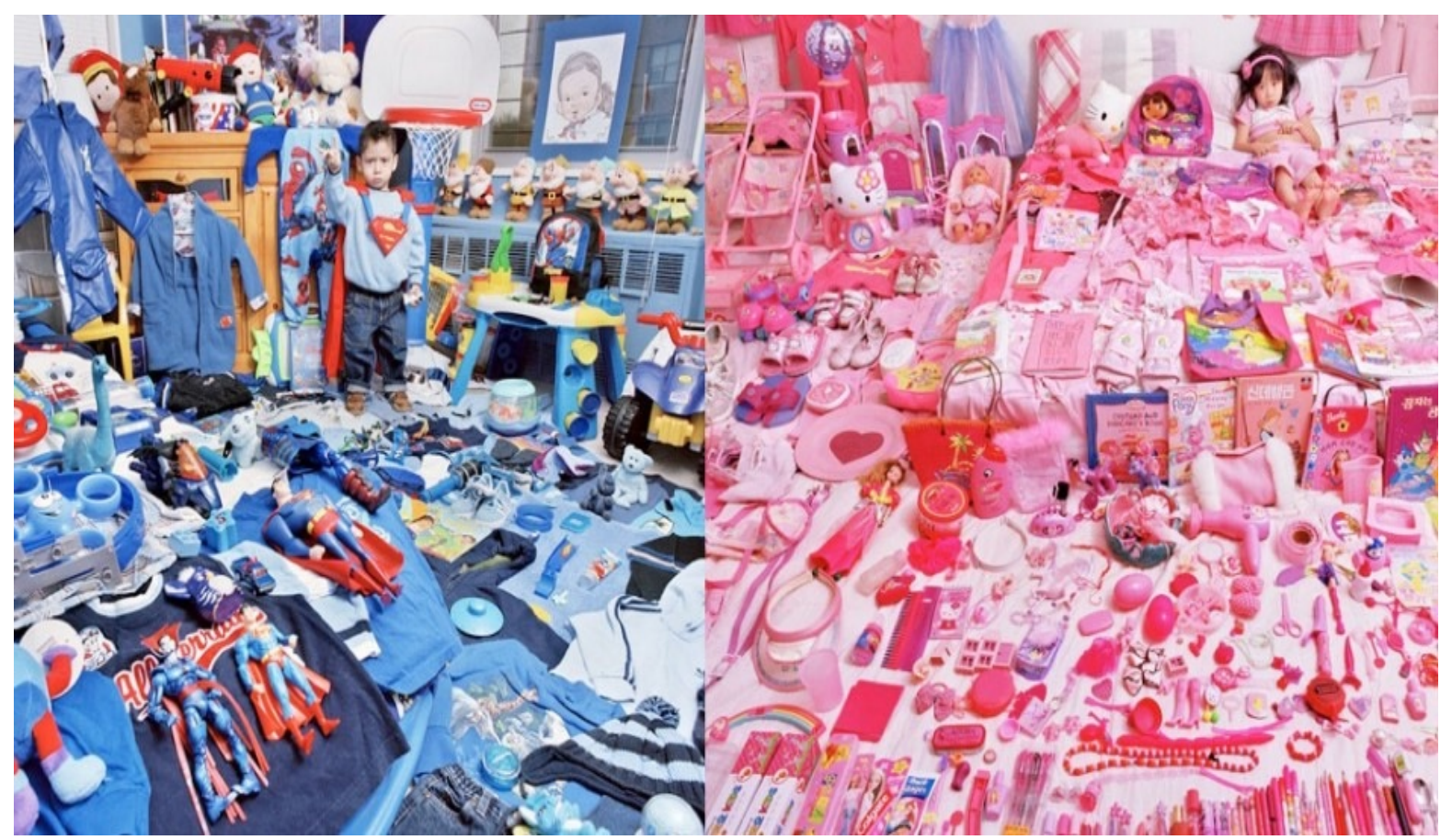

Fig. 2. Distribution of goods for children based on established male/female patterns

This simple example shows the enormous gap between societies between boys and girls, stimulating some into active action and implementation, and others doomed to the eternal search for lipsticks and nail polish. It is clear that under such an approach, we will not soon see the large number of girls who want to be, for example, physicists, mathematicians, travelers, etc. As it is very difficult to counteract gender stereotypes.

It should be noted that the four main (system-forming) groups of gender stereotypes are conditionally distinguished:

1) masculinity-femininity as characteristics of male and female personality traits;

2) division of spheres of activity, labor activity and areas of socialization of articles; 
3) social roles in the private-family sphere;

4) social roles of articles in the public sphere ${ }^{2}$.

That is why there should be various measures that would help to distinguish between young people "this is necessary, because so do all ... (girls / boys)" and that "I can".

Consequently, we see the presence of gender stereotypes that hinder the development of gender equality ${ }^{3}$.

Consequently, the gender approach is a way that allows humanity to reach a new level of development and will enable a person of the XXI century to become a person capable of demonstrating other ways of interaction with the world and opening new horizons.

\section{The value of a gender approach to the development of gender competence of student youth}

The gender approach is intended to counteract the manifestations of gender discrimination. It is emphasized that UNESCO allocates two levels of gender discrimination in the didactic programs: hidden and open.

Open discrimination is the availability of various educational programs for girls and boys. So, for boys, this will be "productive work", while for girls it will be "maintenance".

Concealed discrimination is the presence of gender stereotypes in school materials, which offer children some identification models. It is this kind of "hidden" curricula present in the content of school education in Ukraine ${ }^{4}$.

Speaking about education and training, the following should be emphasized. In addition to the officially recognized content of the learning process, there is a so-called hidden curriculum. This term was suggested by the American teacher Philip Jackson ${ }^{5}$. He noted that such a hidden curriculum might contain elements that would impose patriarchal principles and relationships; they can be found at different levels of the educational institution:

\footnotetext{
${ }^{2}$ Як навчати школярів долати гендерні стереотипи: конспекти занять / навч.-метод. посібник для загальноосвітніх навчальних закладів. Т. Говорун, О. Кікінежді та ін., за заг.ред. професора Т. Говорун. К.: ТОВ «Дорадо-Друк», 2006. 804 с.

${ }^{3}$ Говорун Т. В., Кікінежді О. М. Стать та сексуальність: психологічний ракурс. Тернопіль: Навчальна книга - Богдан, 1999. 343 с.

${ }^{4}$ Як навчати школярів долати гендерні стереотипи: конспекти занять / навч.-метод. посібник для загальноосвітніх навчальних закладів. Т. Говорун, О. Кікінежді та ін., за заг.ред. професора Т. Говорун. К.: ТОВ «Дорадо-Друк», 2006. 804 с.

${ }^{5}$ Jackson, Philip W. Classroom society. Life in classrooms. New York: Holt, Rinehart and Winston, Inc., 1968, 177 p.
} 
- in the organization of the functioning of the institution itself (when men occupy management positions, although most of them are women; wages are lower than women; obstacles to career growth ("glass ceiling"), etc.);

- in the content of educational disciplines (for example, military training for boys, medical - for girls);

- in the teaching and assessment style of students (this may be in the promotion of guys to the exact sciences, and girls to the humanities, etc.).

The presence of these three components of the hidden curriculum enhances gender inequality. Particular attention needs to be paid to the analysis of the content of textbooks that often demonstrate sexism, since it is sexism that is the basis for promoting gender inequality ${ }^{6}$.

As stated in the book "How to teach students to overcome gender stereotypes: notes of lessons" (according to the editorial board of Professor T. Govorun), the gender expertise of texts of textbooks and manuals using the method of content analysis showed a significant number of texts emphasizing the distinction between social the roles of girls and boys ${ }^{7}$. The presence of such texts contributes to the functioning of gender myths and supports the existence of gender inequality.

It is clear that the process of studying in higher education institutions has more freedom than school education. That is, we can talk about the ability of institutions of higher education to decide on or promote gender equality, or, on the contrary, to take steps to implement a gender-based approach to gender equality. These steps include the introduction of courses on gender equality, psychological training that would raise the level of self-awareness and pushed young people to reflection and rethinking of established social patterns.

The importance of implementing a gender approach is in the interaction between young people (student youth), especially young people. Since this age is characterized by a high level of selfawareness.

Confirming the special status of adolescence, the representative of the sociogenic direction of mental development R. Heavigherst, identified the eight major tasks of development that must be addressed in adolescence:

\footnotetext{
${ }^{6}$ Куравська Н. Гендерні стереотипи як джерело гендерної дискримінації та сексизму. URL: file:///D:/ГЕНДЕР2019/3729-10766-1-SM.pdf (дата звернення: 16.06.2019).

7 Як навчати школярів долати гендерні стереотипи: конспекти занять / навч.-метод. посібник для загальноосвітніх навчальних закладів. Т. Говорун, О. Кікінежді та ін., за заг.ред. професора Т. Говорун. К.: ТОВ «Дорадо-Друк», 2006. 804 с.
} 
1) acceptance of the appearance and ability to effectively possess the body;

2) formation of new and more mature relations with peers of both sexes;

3) assimilation of their gender role;

4) achievement of emotional independence from parents and other adults;

5) preparation for professional life, which could ensure economic independence;

6) preparation for the creation of family and family life;

7) the emergence of a desire to bear social responsibility and the development of appropriate behavior;

8) building a system of values and ethical principles that can be guided in life, that is, the formation of their own ideology ${ }^{8}$.

The result of solving the problems of youth, according to the scientist, is the onset of maturity. If an individual does not manage to handle them, he begins to feel anxiety and, without receiving social approval, is not able to function as a mature person.

Youth is one of the most important and responsible stages in the development of personality. This is a period that marks the transition from adolescence to independent adult life. Youth is the time of awareness of oneself, the intense formation of the self-concept, the hierarchy of motives, the construction of the primary life perspectives.

The young age is characterized by awareness of their own individuality, uniqueness, disparity, and so on. L. Bozhovic emphasizes that in this age the main attention is focused on the development of the person's motivational sphere: the definition of his place in life, the formation of a worldview, which, in turn, affects cognitive activity, self-awareness and moral consciousness. The young man forms an internal position, through the prism of which is the perception and subsequent attitude to the environment in which he is, to himself and others $^{9}$. As we see, a special role is assigned to the problem of the attitude and individual growth of a young man.

G. Abramova emphasizes the importance of this age period through the process of processing two important new forms: the concept of life and the self-concept, where "the degree of identity I am for myself is the

\footnotetext{
${ }^{8}$ Райс Ф., Долджин К. Психология подросткового и юношеского возраста. СПб.: Питер, 2012. $816 \mathrm{c}$.

${ }_{9}^{9}$ Божович Л. И. Проблемы формирования личности: Избр. психол. тр. / Под ред. Д.И. Фельдштейна; Рос. акад. образования, Моск. психол.-соц. ин-т. - 3-е изд. М.: МПСИ. 2001. 349 с.
} 
force that will determine success in the implementation of intentions about their own lives" ${ }^{10}$.

An important heritage of youth is the desire for self-determination in both personal and social spheres. In the process of seeking for themselves, the young man forms his own views on life, on the peculiarities of past experience; there is a process of rethinking its past that gives information for reflection on its future.

Youth is a period between childhood and adult life and is essential for the formation of a person's outlook. Early adolescence is the beginning of the practical implementation of life plans, where the main issues are the following: "what to be?" (Moral and personal choices) and "who to be?" (Professional choice). These two processes are parallel and interdependent.

In the concept of age-old periodization, D. Elkonin, adolescence is characterized by the presence of a complex and deep crisis that arises as a result of the young person's transition from the motivation-need sphere to operational-technical capabilities, that is, "wants" more than "able to do". This leads to conflicts among boys ${ }^{11}$.

In a young man, compared with a teenager, I become more stable self-concept, there is a stabilization of inner life, which is manifested, in particular, in reducing the level of anxiety from adolescence to adolescence. However, changing social roles, the need to make important decisions regarding the future profession and lifestyle can lead to a role conflict and status uncertainty ${ }^{12}$.

It is in the young age is forming the ability to self-actualization - the integral, basic personality characteristic that reflects the higher level of its development, the maximum manifestation of its creative abilities and the central criterion of the fact that the person "has taken place".

The problem of choosing vital values is determined in domestic psychology as one of the basic issues that should be solved by the young man. It is at the young age that a young man deliberately finds his place among the categories of good and evil. The developed reflection helps the young man in correlation of the intimate (own thoughts, experiences, etc.) to normative (cultural and social concepts of good and evil, standards of behavior, etc.), and making decisions in favor of one of directions.

\footnotetext{
${ }^{10}$ Абрамова Г.С. Возрастная психология. Екатеринбург: Деловая книга, 1999. 621 с.

${ }^{11}$ Божович Л. И. Проблемы формирования личности: Избр. психол. тр. / Под ред. Д.И. Фельдштейна; Рос. акад. образования, Моск. психол.-соц. ин-т. - 3-е изд. М.: МПСИ. 2001. 349 с.

${ }^{12}$ Абрамова Г.С. Возрастная психология. Екатеринбург: Деловая книга, 1999. 621 с.
} 
It is precisely in adolescence that new development mechanisms for identification-isolation, which have their own specifics, are being developed: the young man is both "hotter" and "cooler" at the same time than a person in other age periods. In youth, the ability to sense the states of others becomes exacerbated, to emotional experiences and empathy for them. At this age, the young man is deepening and experiencing ambivalent feelings, where one pole takes love (identification), the other is hatred (isolation to an extreme degree) ${ }^{13}$.

Young people are characterized by aspirations to another, especially the opposite sex. Youth is a period of life when over all other feelings can dominate the feeling of passion for another: at this age-old person continues to reflect his relationship with his family, finding his place among the loved ones. The young man/woman goes through fencing and even alienation from all those who loved him/her, who was responsible for him/her in his childhood and adolescence. However, this is not teenage negativism, but often loyal, but firmly removed from their relatives, in order to build relationships of different quality: not at the level of "adultchild", but at the level of "adult-adult". This is the age of strength of strength I, his/her ability to manifest and defend his personality ${ }^{14}$.

The juvenile age is characterized by sex-role identification, the successful passing of which helps the young man in his later life ${ }^{15}$.

For this age-old stage is characterized by the first strong sense of love, the search for a close "spirit" of man; Such an aspiration can contribute to the rapid marriage of a young man. However, teenage marriages, as a rule, are not strong enough. According to G. Abramova, the possible explanation for this is that the marriage contracting by boys/girls is due to the feeling of solitude, and not because of the sense of completeness of life ${ }^{16}$.

As you can see, the youth age has a great "load" on gender identification and follow-up, or a rethinking of established gender stereotypes. It can be said that in the juvenile age there is an active phase of "implementation" of the gender issue. After all, the building of intimate relationships with the opposite sex requires the young man to build interaction with his/her partner in a certain way. And what kind

\footnotetext{
${ }^{13}$ Райс Ф., Долджин К. Психология подросткового и юношеского возраста. СПб.: Питер, 2012. 816 c.

${ }^{14}$ Абрамова Г.С. Возрастная психология. Екатеринбург: Деловая книга, 1999. 621 с.

${ }^{15}$ Говорун Т. В., Кікінежді О. М. Стать та сексуальність: психологічний ракурс. Тернопіль: Навчальна книга - Богдан, 1999. 343 с.

${ }^{16}$ Абрамова Г.С. Возрастная психология. Екатеринбург: Деловая книга, 1999. 621 с.
} 
of interaction this interaction will have will depend on how a young person will be able to interact with established gender stereotypes and whether he/she will be able to see a personality in his partner. Will young people "meet" at the level of proximity, beyond the limits of social expectations. This will mean the level of autonomy, if we speak the language of transactional analysis, and this will mean going beyond the life script, which is the way to go beyond the gender scripts ${ }^{17,18}$.

Youth is an extremely important stage in the formation of an individual. Entering this period as a teenager, the young man/woman ends up with his/her adult, when the person himself/herself determines for himself/ herself a destiny: the way of his/her spiritual development and earthly existence. It is during this age that the young man/woman overcomes the dependence on adults and is confirmed as an independent person $^{19}$. The young person anticipates, plans, what place he/she will occupy among people, what kind of activity he/ she will be engaged in, what style of his/her life will be. He/she himself/ herself decides who to be and who he/she is, he/she is responsible for the direction of deployment of the life path that he/she chose. Whether the way to promote equality, including gender, will be chosen, on the contrary, will contribute to the existence of gender inequality.

Human personality is different from all living opportunity to selfexamination and self-understanding. The process of awareness of the person himself/herself is important for the realization of the life path of the individual, the realization of his/her own life plan beyond the limits of established social stereotypes.

Self-understanding is a necessary condition for the adequate functioning of the individual in the process of interaction with the environment, other people, with oneself. A deep knowledge of the characteristics of one's own soul, makes it possible to build a harmonious life.

The process of self-consciousness determines the whole deployment of the human person and does not deviate from any sphere of human life. Reflection and gender stereotypes can not be ignored, which to a large extent determine the behavioral manifestations of man/woman in relation to himself/herself and others.

\footnotetext{
${ }^{17}$ Берн Э. Игры, в которые играют люди. Психология человеческих взаимоотношений; Люди, которые играют в игры. Психология человеческой судьбы / пер. с англ. Екатеринбург: Литур, 2001. $576 \mathrm{c}$.

${ }^{18}$ Steiner C. Scripts People Live: Transactional Analysis of Life Scripts. Grow Press: New York, 1990. 332 p.

${ }^{19}$ Малкина-Пых И.Г. Справочник практического психолога. М.: Изд-во Эксмо, 2007. 784 с.
} 
That is why, for the person to go beyond the limits of his/her own limiting "framework" (which we also refer to as the "framework" of gender ${ }^{20,21}$ ) there should be immersion in his/her experience and the isolation of introverts that were formed during the formation of man/woman ${ }^{22}$. Awareness of such introverts will allow a person to build relationships with others outside the gender stereotypes.

Changing the course of life and deploying it outside of established social expectations should be based on the search for the reasons that led to the creation of an existing life situation. However, such a search would be impossible without understanding the personality of himself/herself, his/her inner world. Such a search is based on reflection: self-reflection and reflection of life events. Since the experience gained by a person during his/her formation has a strong emotional background and makes the analysis of gender discriminatory manifestations more meaningful (emotional and motivational). Awareness of oneself, motives of their actions, understanding of hidden determinants (in particular, stereotypes) gives an individual the ability to self-actualize their potential. Promotes awareness raising in issues related to gender-based stereotypes and allows people to rethink "labels" that were introspectively developed by a person during its development.

Deployment of the human way of life is due to the multitude of events that have taken place in life. To construct a harmonious life, an understanding of the causes of those or other phenomena in the life of the individual (cognitive sphere) needs to be understood. In addition, the analysis and understanding of past events provides an opportunity for constructing a meaningful future, which should take place outside of established stereotypical expectations.

An important component of the research of gender stereotypes is to determine the emotional and motivational component. A significant effect in the research of gender stereotypes is the reflexive training ${ }^{23}$, as a result of which exercises, the person "opens" two motivating forces: external and internal: external, in most cases, connected with the fulfillment of what is necessary (the principle "is necessary"). What imposes a society, saying

\footnotetext{
${ }^{20}$ Бем С. Линзы гендера: Трансформация взглядов на проблему неравенства полов / [пер. с англ.]. М.: «Российская политическая энциклопедия» (РОССПЭН), 2004. 336 с.

${ }^{21}$ Money J. Gendermaps: Social Constructionism, Feminism, and Sexosophical History. New York: 1995. $274 \mathrm{p}$. 2005. $480 \mathrm{c}$.

${ }^{22}$ Перлз Ф. Практика гештальттерапии. М.: Институт Общегуманитарных Исследований,

${ }^{23}$ Ялом И. Групповая психотерапия. Теория и практика. М.: Апрель Пресс, Изд-во ЭКСМО-Пресс, 2001. 576 с.
} 
that "so right". By thus limiting a person to create his/her own livelihoods in such matters as: who to be, with whom to be, what to be.

The internal motivating forces relate to what the person would like to do (the principle of "want"). The analysis of the motivating forces, their influence on the person, the process of incarnation (or non-implementation) into life, is very important for understanding the formation of the subject and his ability to go beyond gender stereotypes. However, only consciousness is not enough to realize the potential of the individual. There have to be actions aimed at changing the course of life. It is here that the choice of a person must take place: either by promoting my actions or actions I am contributing to inequality, or, conversely, building up gender equality. It is important to remember this, since gender equality begins with an individual. And we must talk about personal choice and the ability to implement it (volitional sphere).

Awareness of gender stereotypes is important for every individual, since it allows you to look at yourself and your life path from a different angle. Understand and feel that it is possible in a different way. What life itself has to do with its own plan, and that the 21st century offers all the opportunities to be a person who knows what he/she wants and can realize his/her potential beyond the stereotypes. What social expectations like "you are a girl", "you are a boy" should not stand on the path to selfdeployment and realization of a real personality.

Recall that the gender competence of the person contains the following components:

1) knowledge of the existing situation of gender inequality, as well as the factors and conditions that cause it;

2) the ability to observe and adequately assess the situation of gender inequality in different spheres of life;

3) the ability not to display gender discrimination in their behavior;

4) the ability to solve their gender problems and conflicts if they arise $^{24}$.

Therefore, on the basis of the above, we can distinguish the following levels regarding the development of gender competence in student youth.

1)the formation of gender competence in boys should be at a cognitive level. First of all, this should be through active educational activities both at the state level and at the level of institutions of higher education. This includes training sessions, special courses on gender

24 Шевченко 3. В. Словник гендерних термінів. Черкаси: видавець Чабаненко Ю., 2016. URL: http://a-z-gender.net/ua/\%D2\%91ender.html (дата звернення 05.06.2019). 
equality, advocacy campaigns that should bring young people the importance of understanding and countering gender stereotypes.

2)also, gender education programs should include an emotional and motivational component. This means that the content and form of interaction with the youth should be constructed in such a way that they have an "emotional response" (which means not indifference to gender issues). Because the emotional and motivational sphere is the stimulating factor that pushes the person to certain actions and actions.

3) and the third sphere, which should be covered by gender education, is the level of voluntary regulation, which should be realized through the system of active actions. In this context, these are actions aimed at overcoming gender inequality.

In the opinion of the existential psychologist R. Mey, the less developed the self-consciousness of a person, the more dependent it is from life circumstances, various displaced content communications that were formed in childhood. "Through self-consciousness, we can interrupt a series of stimuli and reactions, create a pause in it, in which we can make a conscious choice of our reaction" ${ }^{25}$. As the self-consciousness develops, the range of human choice and its existential freedom increases accordingly.

The freedom to choose an individual is related to the reflection of the contradictions that arise in the situation of choosing a solution (the choice of some alternatives). Making a choice requires a person to take responsibility for the implementation or non-implementation of his/her life plan.

Category of responsibility indicates the problem of the relationship between the ability and ability of a person to act as a subject (author) of his/her own actions. Responsibility involves building a situation for a person with a purpose - consequences for himself/herself and for others. Responsible person at any stage of the choice reflects the possible consequences of the implementation or rejection of the possible alternatives and is responsible for them.

Consequently, the emergence of gender competence should take place with the involvement of all spheres of the human psyche: cognitive, motivational and regulatory. The introduction of a gender-based approach to all areas of society's functioning is of great importance in overcoming gender inequality.

\footnotetext{
${ }^{25}$ Мэй Р. Мужество творить: очерк психологии творчества. Львов: Инициатива, 2001. 180 с.
} 
The issue of implementing the gender approach in the system of institutions of higher education is particularly acute, as they are the institutions where the personality of the professional develops.

And today for Ukraine it is of immense importance whether this professional will be gender-competent and profess the ideas of democracy and a socially responsible society.

\section{CONCLUSIONS}

As a result of the theoretical analysis, we have clarified the concept of "gender approach", "gender competence", "hidden gender discrimination". The theoretical analysis allowed to determine the peculiarities of the application of the gender approach and its role in the formation of a socially oriented society.

In the context of contemporary Ukrainian society, the study of gender discrimination requires more attention. Of particular importance is the question of finding methods that will reduce the level of manifestation of gender discrimination. One of these methods is the gender approach. It is this approach that focuses on the gender issue and requires society to always keep a gender perspective.

We have determined that the formation of a future professional in the system of institutions of higher education should be focused on the formation of gender competence. As a professional of the future is a gender-competent professional. A person capable of fulfilling his professional functions without deepening the level of gender discrimination.

It is a person who is able to go beyond the limits of established social stereotypes and contribute to democratic transformations in the state. Since adolescence is a sensational period before rethinking oneself and their values, this is where reflexive activity should take place, which should facilitate the emergence of the individual beyond gender-based stereotypes. Such rethinking should take place at the cognitive, emotional and regulatory level.

The formation of the gender competence of young people should take place in the process of studying at higher education institutions. Because these institutions are institutions that form a person in a moral and professional way.

Implementation of the gender approach will create conditions for the successful formation of a professional who has a high level of gender competence. The goal of higher education institutions is to implement a 
gender-based approach at all levels of the educational process (especially in the context of working with young people) and seek to establish a society beyond the limits of discriminatory manifestations.

\section{SUMMARY}

This article is devoted to the issue of gender approach as the main method of counteracting gender discrimination. The emphasis is placed on the fact that the implementation of this approach is of particular importance in the context of the European vector of development of the Ukrainian state.

It is determined that in Ukraine there is a legislative base that regulates the gender issue and promotes gender equality (starting with the main law - the Constitution of Ukraine). It is emphasized that there is a discrepancy between what is written and what is happening in reality.

The necessity of introducing a gender approach to the education system, including those in higher education institutions, is indicated. Taking into account the competence approach in the system of higher education, the role of institutions of higher education for the formation of a professional person is emphasized. However, professionalism must go hand in hand with moral and ideological values, which, first of all, should be aimed at the development and establishment of democracy.

That is why the paper emphasizes the necessity of introducing a gender approach into the educational process and the functioning of educational institutions. In addition, the issue of gender competence in young people is relevant to modern pedagogy and psychology.

The theoretical analysis allowed to distinguish youthful age as a sensitive period for rethinking stereotypes, including gender-specific ones. Due to the registration of the regulatory (volitional) sphere (in comparison with the previous age periods) the young man/woman has the opportunity to implement (and not only realize) in his/her life the interaction with other people outside the rigidly defined framework (including gender).

An important role in the formation of gender competence and the ability to implement it in the professional and other spheres of life of the individual belongs to higher education institutions. And the future of the younger generation, and, consequently, our country, depends on the willingness and ability of these institutions to implement a gender-based approach. 


\section{REFERENCES}

1. Абрамова Г.С. Возрастная психология. Екатеринбург: Деловая книга, 1999. $621 \mathrm{c.}$

2. Бем С. Линзы гендера: Трансформация взглядов на проблему неравенства полов / [пер. с англ.]. М.: «Российская политическая энциклопедия» (РОССПЭН), 2004. 336 с.

3. Берн Э. Игры, в которые играют люди. Психология человеческих взаимоотношений; Люди, которые играют в игры. Психология человеческой судьбы / пер. с англ. Екатеринбург: Литур, 2001. $576 \mathrm{c.}$

4. Божович Л. И. Проблемы формирования личности: Избр. психол. тр. / Под ред. Д.И. Фельдштейна; Рос. акад. образования, Моск. психол.-соц. ин-т. - 3-е изд. М.: МПСИ. 2001. 349 с.

5. Говорун Т. В., Кікінежді О. М. Стать та сексуальність: психологічний ракурс. Тернопіль: Навчальна книга - Богдан, 1999. $343 \mathrm{c}$.

6. Конституція України. URL: https://zakon.rada.gov.ua/laws/show/ 254\%D0\%BA/96-\%D0\%B2\%D1\%80 (дата звернення: 19.06.2019).

7. Куравська Н. Гендерні стереотипи як джерело гендерної дискримінації та сексизму. URL: file://D:/ГЕНДЕР2019/3729-107661-SM.pdf (дата звернення: 16.06.2019).

8. Малкина-Пых И.Г. Справочник практического психолога. М.: Изд-во Эксмо, 2007. 784 с.

9. Мэй Р. Мужество творить: очерк психологии творчества. Львов: Инициатива, 2001. 180 с.

10. Перлз Ф. Практика гештальттерапии. М.: Институт Общегуманитарных Исследований, 2005. 480 с.

11. Райс Ф., Долджин К. Психология подросткового и юношеского возраста. СПб.: Питер, 2012. 816 с.

12. Як навчати школярів долати гендерні стереотипи: конспекти занять / навч.-метод. посібник для загальноосвітніх навчальних закладів. Т. Говорун, О. Кікінежді та ін., за заг.ред. професора Т. Говорун. К.: ТОВ «Дорадо-Друк», 2006. 804 с.

13. Шевченко 3. В. Словник гендерних термінів. Черкаси: видавець Чабаненко Ю., 2016. URL: http://a-z-gender.net/ua/\%D2\% 91ender.html (дата звернення 05.06.2019).

14. Ялом И. Групповая психотерапия. Теория и практика. М.: Апрель Пресс, Изд-во ЭКСМО-Пресс, 2001. 576 с. 
15. Goulding R., Goulding M. Injunctions, decisions, and redecision // Transactional Analysis Journal. - 1976, Vol. 6, № 1. - P. 41-48.

16. Jackson, Philip W. Classroom society. Life in classrooms. New York: Holt, Rinehart and Winston, Inc., 1968, 177 p.

17. Money J. Gendermaps: Social Constructionism, Feminism, and Sexosophical History. New York: 1995. 274 p.

18. Steiner C. Scripts People Live: Transactional Analysis of Life Scripts. Grow Press: New York, 1990. 332 p.

\section{Information about the author:}

Kostina T. O.

Candidate of Psychological Sciences, Associate Professor at the Department of Psychology and Pedagogy of the V. I. Vernadsky Taurida National University 33, John McCain str., Kyiv, 01042, Ukraine 


\section{PSYCHOLOGICAL AND PEDAGOGICAL BASES FORMING OF PROFESSIONAL COMPETENCE OF THE FUTURE EXPERT}

\section{Kostyuchenko O. V.}

\section{INTRODUCTION}

Increasing requests of the transformational socio-cultural environment to the professionalism of experts in all areas requires original methods and means of formation and development, production of original ideas, the flexibility of thinking and behavior, mobility, autonomy, opening to new forms of professional self-realization. A famous contemporary American philosopher Alvin Toffler determined that “... the world emerging quickly from the collision of new values and technologies, geopolitical relations, lifestyles, and means of communication requires completely new ideas and analogies, classifications, and concepts" ${ }^{\text {" }}$ based on the analysis of the phenomenon of the transformation of modern societies. This concept is based on the modern social paradigm - from technocratic to industrial, from industrial to informational due to the educational formation of developed countries. Undoubtedly, social integration processes and such areas of the social development as globalization, democratization, dissolution of the NATO Member Countries, the creation of a single information space, determine the requirement of the constant reformation and updating of the education system at all levels.

The implementation of high-quality and effective training at the present stage of development of higher education intends to create the conditions, innovative technologies, and techniques, the search for variative systems, and models for the formation, development, and selfrealization of a competent specialist. In our opinion, increasing attention to forming, the development, and self-fulfillment of the professional competence of the future specialist is associated with the following indicative properties: readiness to professional self-realization, further personal and creative development, active participate in society; the ability to operate with such technologies, knowledge, and information that meets the needs of the information society, preparation for new roles in this society; readiness to change and adapt to the new needs of the labor

\footnotetext{
${ }^{1}$ Тоффлер Е. Третя хвиля. Київ: Вид. дім «Всесвіт», 2000. С. 14.
} 
market, to actively act and interact with the technological community, to make quick decisions, to study throughout life, etc.

According to the analysis of the experience of educational systems of many progressive countries, one of the ways to update the content of education and teaching technologies, aligning them with modern needs, integration into the educational global space is the orientation of educational programs to a competent approach and the creation of effective mechanisms for its introduction.

The problem solution of the formation and enhancement of the professional competence of specialists is represented in the works which are devoted to the professional training of specialists (V. Andrushchenko, M. Yevtukh, I. Zyazyun, V. Kremen); the concepts of the characteristics of professional activity (B. Ananiev, L. Vygotsky, S. Kalmykova, N. Menchinskaya, S. Rubinstein, etc.); the psychological and pedagogical theory and practice of European teachers (V. Doll, J. Deller, J. Callahan, J. Perret, G. Halas, etc.) and psychologists (L. Karpov, T. Kovaleva, N. Lobanova, L. Mitina, A. Makarova, E. Ogarev, O. Polunina, V. Slastonin, M. Choshanov, etc.).

Therefore, it is appropriate to state that the theoretical and practical process of forming professional competence of future specialists and its components in the process of study is insufficiently studied. There is a set of unstudied aspects of the mentioned problem especially the psychological aspects of professional competence development by means of project activity, creative and adaptive potential of teaching as a process of mastering various social experience and development of new models of behavior, and changes in value orientations, emergence of new cultural needs, and interests are not sufficiently specified.

The purpose of this publication is to do a comprehensive and integrated analysis of the psychological components of the formation of the professional competence of future specialists especially the realization of the creative and adaptive potential of learning by means of project activity, based on local and foreign experience which will further increase the level and quality of training and readiness for future professional activities.

\section{The competency approach to the formation of professionalism of a future specialist}

In the scope of this article, considerable interest is formed by scientific papers in which psychological approaches to the formation of professional competences of a future specialist are represented at the 
present stage of research. Among the many definitions of the DeSeCo project (Definition and Selection of Competencies, 1997), the definition of competence is fully represented. This is the ability to successfully meet individual and social needs, act and perform tasks. Each competency is built in the combination of mutual relevant cognitive attitudes and practical skills, values, emotions, behavioral components, knowledge, and skills, all that can be mobilized for active action ${ }^{2}$.

The substantive characteristics of the category "professional competence" as indicators of the level of professional training of a future specialist are showed in detail in the following researches: the concepts of "competence" and "capacity" in foreign and national scientific papers (K. Osadcha) ${ }^{3}$; the interpretation of competence as an approach to knowledge - a method for solving life problems, making decision in various spheres of human life, general ability based on knowledge, experience, values acquired through education, upbringing, integration into the space of social and cultural relations, interpersonal integration, and communication (I. Yermakova, G. Nesen, L. Sokhan) ${ }^{4}$; the formation method of the communicative competence of the future leader and manager (V. Bondarenko, L. Gren, Y. Panfilov) ${ }^{5}$; the definition of the competence components as properties (V. Kovalchuk, N. Kuzmin) ${ }^{6}$, productive-activity characteristics of education (O. Pometun) ${ }^{7}$, characteristics and abilities of people allowing them to achieve personally meaningful goals regardless of their nature and the social structure in which they live and work (D. Raven) ${ }^{8}$, the maturity of a person is based on professional activity (A. Markova) ${ }^{9}$; searching of ways formation and use of professional competence of future specialists; the development of methods of "general program competences" and knowledge based on "graduation" requirements

\footnotetext{
${ }^{2}$ Definition and Selection of Competencies. Theoretical and Conceptual Foundations (DESECO). Strategy Paper on Key Competencies. An Overarching Frame of Reference for an Assessment and Research Program - OECD (Draft).

${ }^{3}$ Осадча К. П. Аналіз понять «компетенція» та «компетентність» у зарубіжній та вітчизняній науковій літературі [Електронний ресурс]. Педагогічний дискурс. 2011. Режим доступу до ресурсу : file://C:/Users/Валерa/Desktop/peddysk_2011_9_61\%20(2).pdf.

${ }^{4}$ Життєва компетентність особистості / За ред. Л. Сохань, І. Єрмакова, Г. Несен. Київ, 2003. 250 с.

${ }^{5}$ Панфілов Ю. І., Бондаренко В. В., Грень Л. М. Методика формування комунікативної компетентності майбутнього лідера-менеджера. Теоретичні та прикладні аспекти дослідження феноменів лідерства, управління та розвитку соціального об 'єкта. 2016. №2. С. 10-19.

${ }^{6}$ Ковальчук В. В. Сутнісно-змістовна характеристика категорії «професійна компетентність» як показника рівня фахової підготовки студентів. Проблеми інженерно-педагогічної освіти. 2007. № 18-19. C. 84-88.

${ }^{7}$ Компетентнісний підхід у сучасній освіті: світовий досвід та українські перспективи: Бібліотека 3 освітньої політики / Під заг. ред. О. В. Овчарук. Київ : «К.І.С.», 2004. 112 с.

${ }^{8}$ Равен Дж. Компетентность в современном обществе. Москва: Когито-Центр, 2002. 395 с.

${ }^{9}$ Маркова А. К. Психология профессионализма. Москва: Знание, 1996. 308 с.
} 
of students; realization of education competencies in K-12 system (C. Sturgis) ${ }^{10}$; the professional competence as a way of being; an existential ontological perspective (J.Sandberg) ${ }^{11}$; educational competencies or education for professional competence (M. Hoverts) ${ }^{12}$; the expert assessment of professional competence (E. Dannefer) ${ }^{13}$; definition and evaluation of professional competence (R. Epstein) ${ }^{14}$; assessment of competence in the field of professional technical characteristics of various disciplines and professions (P. Wimmers) ${ }^{15}$.

There are still discussions on defining the content of the concepts "competence”, "capacity", their correlation, and the existence of different approaches to the classification of key competencies.

The term "competence approach" means the orientation of the educational process to the formation and development of the key (standard, basic), substantive competences of the individual; the gradual reorientation of the dominant educational paradigm with the prevailing translation of knowledge, the formation of skills for creating the conditions for mastering a complex of competencies which signify potential, ability to survive, and stable livelihoods in the conditions of modern multidimensional sociopolitical, market-economic, information, and communication-intensive space (G. Selevkov). O. Novikov believes that this approach is based on the concept of competences as a basis for the formation of students' ability to solve important learning activities and upbringing of the individual as a whole ${ }^{16}$. The result of this process will be the formation of general competence as a set of key competencies and an integrated personality trait that includes its knowledge, skills, attitudes, experience, and behavioral models. The competent approach in education is related to personally oriented and active approaches to learning, since it concerns the personality of the future specialist and can be implemented

${ }^{10}$ Sturgis, C. Implementing Competency Education in K-12 Systems: Insights from Local Leaders. CompetencyWorks Issue Brie [Електронний ресурc]. International Association for K-12 Online Learning. 2015. Режим доступу: http://files.eric.ed.gov/fulltext/ED557750.pdf.

11 Sandberg, J. Professional competence as ways of being: An existential ontological perspective. Pinnington. Journal of Management Studies. 2009. T. 46. P. 138-170.

12 Govaerts, M. J. Educational competencies or education for professional competence?. Medical education. 2008. T. 42. №3. P. 234-236.

${ }^{13}$ Dannefer, E. F. Peer assessment of professional competence [Електронний pecypc] / [Е. F. Dannefer, L. C. Henson, S. B. Bierer, T. A. Grady-Weliky, S. Meldrum, A. C. Nofziger et al. ]. Medical education. 2005.

${ }^{14}$ Epstein, R. M., Hundert E. M. Defining and assessing professional competence. American Medical Association. All rights reserved. 2002. № 2. P. 226-235.

${ }^{15}$ Wimmers, P. F. Mentkowsk, M. Assessing Competence in Professional Performance across Disciplines and Professions. Los Angeles, CA, USA : Springer, 2016. 473 c.

16 Управління формуванням професійної компетентності магістрантів педагогіки вищої школи: теоретико-методичні засади : монографія. Київ : Дорадо-Друк, 2013. С. 18-16. 
and tested only by the implementation of a student a particular set of actions ${ }^{17}$.

Generally speaking, the concept of key competencies are determined as an ability of the individual to participate effectively in many social fields, contribute to improving the quality of society, and contribute to personal success that can be applied to many spheres of life. The key competencies consist of the most general concepts which should be detailed in a set of knowledge, proficiencies, skills, values, the educational fields, and life spheres of the individual. One of the most important theoretical generality of the discussion about the concept of key competencies is the definition of three categories of key competencies as a conceptual base by representatives of the Organization for Economic Cooperation and Development (OECD) - autonomous activity; interactive use of resources and ability to function in socially heterogeneous groups.

According to the integrated approach to defining three categories of key competencies "DeSeCo, 2002"18, the following criteria of abilities are distinguished:

- Autonomous action: the ability to protect and take care of the responsibility, rights, interests, and needs of others; the ability to draw up and implement plans and individual projects; the ability to act in a significant or broad context;

- Interactive use of tools: the ability to apply language interactively, symbolism, and texts; the ability to use knowledge and information literacy; the ability to apply (new) interactive technologies;

- Ability to function in socially heterogeneous groups: the ability to successfully interact with others; the ability to cooperate; the ability to solve conflicts.

According to the requirements of the preparation level of future specialists, the key competencies are integral characteristics of the quality of learning associated with their ability to purposeful meaningful application of a set of knowledge, proficiencies, skills, and attitude towards a particular interdisciplinary range of problems. They reflect the subject-activity component of general education and should provide a comprehensive achievement of its goals.

Consequently, we distinguish the following main features of the vital (key) competencies: polyfunctionality is revealed in solving various problems in different spheres of personal and social life; the state of being

17 Компетентнісний підхід у сучасній освіті: світовий досвід та українські перспективи: Бібліотека з освітньої політики / Під заг. ред. О. В. Овчарук. Київ : “К.І.С.”, 2004. С. 64.

${ }^{18}$ там само. С. 10-11. 
a super object and interdisciplinary, that is implemented in various spheres of life; multidimensionality due to the full involvement and development of all components of the personal (self-knowledge, selfdetermination, self-esteem, and self-education), effective, cognitive, and creative sphere.

The goal of the competent-oriented education is becoming highly educated, developed and creative, capable of self-education and selfdevelopment of an individual. The project activity provides the possibility to obtain the appropriate experience and ability which is an instrument that creates unique preconditions for the development of key competencies (social, multicultural, informational, and communicative, etc.) and comprehends the new things independently by the individual.

\section{The project activity is an instrument for the formation and implementation of professional and vital (key) competencies}

The project activity is the strategic instrument of development in various spheres of personal development. The integral concept is based on the interaction of economic, technological, cultural, socio-psychological, and creative aspects. In this context, it is important to study the features: the realization of the project activity (M. Gurevich, A. Kopernik, I. Lerner, N. Matiash, V. Symonenko, I. Sasova, M. Romanovska, etc.), the use of the method of projects in management (O. Marmazi, I. Lyakhov, V. Glazycheva, I. Yermakova, V. Sidorenko, I. Shendrik, etc.), the project education as a means of forming the project method of engagement with the world (Z. Rubtsev, V. Zimova, H. Nechaev, $\mathrm{V}$. Sidorenko, etc.). One of the urgent tasks of the modern stage of development of the educational system which is showed in numerous attempts to improve it is the formation of a specialty of future specialists especially in the psychological and pedagogical sphere, of the project activity, and elements of the project culture.

The formation of the professional self-development of the project activity specialists allows focusing on personal development, ability to possess cognitive knowledge of a higher level, social significance of activity, ability to self-improvement, formation of professional competencies, professional and social orientation, effective analysis of professional activity, and independence of professional qualification improvement future specialists.

Before analyzing the peculiarities of the project activity as professional competence, one should give examples from the psychological 
literature of the definitions of "professional competence" which explain its essential characteristics, principles, and concepts which it is based on ${ }^{19}$. Thus, professional competence is considered as an individual characteristic of the degree of compliance with the requirements of the profession which is defined as a combination of mental qualities; a mental state that allows someone to act independently and responsibly (effective competence); the possession skills and ability to perform certain labor functions; personally professional, socially significant qualitative characteristic of a specialist who can use knowledge, skills, abilities not only for professional activity but also for understanding social significance and moral consciousness of activity; professional-status opportunities concerning state, social, and personal powers in professional activities; possession of the relevant competence including the personal attitude to him/her and a subject.

At the same time, the ability to project activities as competence includes a set of interrelated personality traits (knowledge, skills, abilities, work method), that are regarded with a certain range of objects, processes, and effective actions. It includes a concept that of three aspects: a problem-practical aspect which is an adequate understanding of the situation, the effective implementation of goals, objectives, and norms; a semantic aspect which is an adequate understanding of the production situation in a more general socio-cultural context; a value aspect which is the ability to the correct assess of a situation, its point, goals, tasks, and norms from the perspective of general and its significant values, etc.

Summing up the different views on the problem of the formation of vital ${ }^{20}$ and professional competencies, the necessary qualities and skills should be identified which the criterion of formation is considered the ability to project activities: flexibility, mobility, competitiveness, ability to engage into dynamic society, represent himself at a labor market; the ability to use knowledge for solving life problems; generation of new ideas, making non-standard decisions, and responsibility for consequences; ability to communicate, ability to work in a team, prevention and resolution of conflict situations; the ability to obtain, analyze, interpret, transmit information obtained from various sources, apply it for the individual development and self-improvement; careful attitude

${ }^{19}$ Барченков Д. А. Психологическое содержание профессиональной компетентности менеджера полифункционального холдинга. Вестник Тамбовского университета. Серия Гуманитарные науки. 2007. № 4. С. 199-206.

${ }^{20}$ Срмаков I. Г. Феномен компетентнісно спрямованої освіти. Крок за кроком до життєвої компетентності та успіху. Київ: Лат і К, 2003. С. 6-8. 
towards his/her health and health of others as the highest value; the ability to choose among the many alternatives to the optimal solution.

The idea of incorporating project activities into the educational process was proposed by an American educator and philosopher John Dewey. It is arguable that the project method is a modern technology nowadays that promotes the effective formation of such key competencies as the future specialists: vocational and pedagogical, social-psychological, communicative, informational and communicative, general cultural, health-saving, civic, etc. It provides opportunities for engagement in research and searching, reinforcement of additional motivation and interest in educational-cognitive activities.

Based on the research of J. Raven proved that the key components of the development of psychological competence are the development environment where conditions for the identification and development of abilities are created, the ability of a future specialist to study deeply the peculiarities of the structure of the organization and institution, firms or companies where s/he works and the specifics psychological thinking of their employees; self-analysis of its activities in order to determine the effectiveness ${ }^{21}$.

It should be noted that the project activity in educational and professional activities is the environment conducive to the implementation and the development of the creative and leadership potential of the personality, forms social skills, abilities, and communicative culture. In addition, the project activity has the following universally recognized psychological features as the intellectual-capacity nature of the subject area of the projects; stipulation of the success of the project with properties of a customer; a high degree of individualization for the customer which requires a full cooperation with him/her; a rapid loss of relevance of the results; high probability of inclusion in new, previously unavailable works that need adaptation or creation of a methodology, technology, and management system; demanding qualification of specialists as managers and executors; a high level of communicative and corporate culture, etc. ${ }^{22}$.

The concept of a projection is defined as a process that gives rise to changes in the artificial environment (J. Johnson) ${ }^{23}$, which develops the design skills of its participants, the ability to navigate the information

\footnotetext{
${ }^{21}$ Равен Дж. Компетентность в современном обществе. Москва: Когито-Центр, 2002. 395 с.

${ }^{22}$ Костюченко О. В., Л. П. Дихнич. Психологія ефективності фахівця індустрії моди. Київ: Ліра, 2016. 464 c.

${ }^{23}$ Джонс Дж. Методы прогнозирования. М.: Мир, 1986. 524 с.
} 
space, to practice knowledge, forms the ability to independently construct his/her activities (L. Vasilevskaya) ${ }^{24}$; a special type of intellectual activity, the distinctive feature of which is the perspective orientation towards a practically directed research (I. Isaev) ${ }^{25}$; a complex activity that features signs of auto-didactics (automatic assimilation by designers without a specially defined didactic task by organizers of new concepts, new ideas about different spheres of life production, personal, socio-political relations, a new understanding of the content of life changes); awareness of the role of "Adult” and responsibility for their own lives (Y. Khrikov) ${ }^{26}$; an independent activity that involves the presence of such a stage as forecasting (a specially organized study aimed at obtaining information on the development of an object) (A. Tsymbalaru) ${ }^{27}$; type of activity that synthesizes elements of the game, cognitive, value-orientational, transformative, professional-labor, communicative, educational, theoretical practical activity (O. Kobernik) ${ }^{28}$; creative, innovative activity since it is always aimed at creating an objective and subjectively new product (A. Leontiev) ${ }^{29}$.

We defined the project in educational activity as a complex of interrelated, focused, consistently oriented, psychological and pedagogical measures in creation of a different kind of items on the basis of traditional and contemporary trends in psychology and pedagogy in limited resources (financial, labor, and material) and specify the terms of beginning and ending. The project is unique as a learning method ${ }^{30}$, which is revealed in targeting the achievement of the goals of future professionals. It is effective in the formation and implementation of a significant number of educational and life competencies which are irreplaceable in the formation of experience.

The project activities include the following key skills as problemsolving, job scheduling, search, compilation, information processing, and presentation of work results. The project activity serves as a way

\footnotetext{
${ }^{24}$ Василевська Л. С. Проектна діяльність методиста як засіб удосконалення професійної майстерності педагогів [Електронний ресурс]. Наукові записки [Ніжинського державного університету ім. Миколи Гоголя]. Сер.: Психолого-педагогічні науки. 2012. № 6.

${ }^{25}$ Исаев И. Ф. Развитие профессионально-педагогической культуры преподавателя в условиях модернизации педагогического образования. Педагогіка та психологія. Харків, 2006. Вип. 29. С. 63-72.

${ }^{26}$ Хриков С. М. Педагогічні умови як складова наукових знань. Шлях освіти. 2011. № 2. С. 11-15.

${ }^{27}$ Цимбалару А. Д. Семантика понятійного апарату проблеми педагогічного проектування. Нова педагогічна думка. 2009. № 3. С. 30-35.

${ }^{28}$ Коберник О. М. Проективна педагогіка і національна школа. Шлях освіти. 2000. № 1. С. 7-9.

29 Леонтьев А. Н. Деятельность. Сознание. Личность. Москва : Политиздат, 1977. 304 с.

30 Власюк О. Проектна діяльність - перспектива розвитку особистості. Проектна діяльність у ліцеї: компетентнісний потенціал, теорія і практика / за ред. С. М. Шевцової, І. Г. Єрмакова, О. В. Батечко, В. О. Жадька. К. : Департамент, 2008. 520 с.
} 
of developing creativity, independence, the desire for an ideally-perspective transformation of the world through creative actions and operations in the process of creating a specific thing which is a project of the ideal and the real ${ }^{31}$. It should be noted that project training contributes to solving such psychological and pedagogical goals as creating positive motivation during training; the formation of mental skills, the development of operation logical thinking; the formation of methods of group work in a team, etc. In addition, the implementation of each kind of projects ${ }^{32}$ requires the activation of various components of the psyche, especially Exploring components (biological, physiological, technical, solution of historical or literary problems) need a well-thought structure, completely subordinated to the logic of research and have the structure of definition of the research methodology, i.e. the subject of the research, argumentation of its relevance, subject and object, tasks and methods of the research, the formulation of hypotheses, ways of problem solving; Creative components (productive and creative) are related to work activity (design, creation of a model, care of plants, and animals) do not have a detailed structure of the joint activity of participants. It develops subordinate to the final result and the form of its presentation (an activities list, a video, a holiday, etc.); Information components aimed at collecting information about an object, phenomenon, for acquaintance the project participants with this information, its analysis, and generalization of the facts; Practical (consumer) components (preparation of excursions, service provision, and organization of leisure) are solving practical tasks of a "customer" of a project and as a result, the development of a visual guide, a layout, an instrument, an equipment, and recommendations for their usage; Gaming (role-playing) components are a graphic representation of real processes and phenomena in stage forms, game situations, as a result, simulation of a real object.

The object-subjective relationship plays a decisive role in the psychological and pedagogical design. Their purpose is to achieve a positive psychological and progressive cultural effect from the project's implementation as a product, item, and action, as well as a means and an instrument of mass communication. Ten urgent in 5 years skills were identified at the Annual World Economic Forum in Davos (Switzerland, 2016) which gathered more than 2,500 top-level leaders including more

\footnotetext{
${ }^{31}$ Хоружа Л. Проектна культура вчителя: етичний компонент. Шлях освіти. 2006. № 4. С. 11-15.

32 Власюк О. Проектна діяльність - перспектива розвитку особистості. Проектна діяльність у ліцеї: компетентнісний потенціал, теорія і практика / за ред. С.М. Шевцової, І.Г. Єрмакова, О.В. Батечко, В.О. Жадька. К. : Департамент, 2008. 520 с.
} 
than 50 leaders of state and government and about a thousand heads of multinational companies. We define an integrated multilevel problem solving, critical thinking, cognitive flexibility, creativity, human ability to manage, interaction, emotional intelligence, the thought formation and making a decision, customer-focused, negotiating skills as a strategic instrument for the project activity.

It should be pointed out that the successful accomplishment of the project-based learning activities (project activities) depends on the efficiency of the interaction between the subjects engaged in psychological and pedagogical practices. Such practices relate to the designing process, producing and distributing the objects of activities: the tendency, the standards and the product (manuals, scientific and popular magazines, newspapers, educational and scientific-methodical materials, presentations, training, workshops, different types of course formats: lectures, seminars, practical, etc.). The profitable application of the project activities also depends on "producers" and "users" of the project products, which multiply the subjects mentioned above; and "distributors" - mass media and PR-aspects (magazines, TV and show programs, presentations, advertising, TV, authoritative personalities, etc.). The following conditions are required for the successful fulfillment of the educational project such as the meaningful research issue; skillful formulation of the key and thematic questions; practical significance of the expected results (publication, poster, anthology, presentation, etc.); independent work; structuring the substance of the project (stages, tasks, distribution of roles, etc.); the usage of research methods; application of computer technologies (for information search, communication with the other project participants, generation of the project's final product).

Now we select the key-points of the follow-up mechanism of the project's technology that are conditions for self-realization of the specialist's personality, and the development of his/her potential capabilities. These conditions can be listed as follows: (1) the organization of stimulating energy flow and information space (content, socio-cultural, educational) for potential development; (2) the organization of various types of activities that are conditions for self-realization of the future specialist. They consist of social communication, socially profitable actions, game, physical and recreational, educational and cognitive, research, artistic and aesthetic, tourist-local lore, scientific and technical, decorative and applied, ecological and naturalistic activities, etc.; (3) the organization of effective communication that creates situation for 
social development of a specialist and shaping a positive "I-concept" plus a culture of dialogue based on interactive forms of practice; (4) systematic psychological support for solving personal problems of the specialists, promoting their self-identification, self-determination and self-actualization; (5) increasing the level of professional skills, projective culture within the circle of the psychological and pedagogical personnel; (6) awareness of his/her personal social responsibility, and constant personal and professional growth.

Thus, a projection is rather fundamentally different subjective than an objective form of participation in social activities and as such, it is a specific individual creative process, which requires from every person original new solutions and at the same time that is a process of collective creativity. The most important achievements obtained during the project activities are shaping the ability to research, the development of public speaking skills, capacity to present the result of his/her work (project product) and affirmation of personal competence, the ability to communicate briefly and convincingly about himself/herself and his/her work. The projection can become a means of social and intellectual creative self-development of all subjects of education (students, teachers, and administrators of educational institutions), and in the narrower sense that is a means for the development of projective abilities.

\section{The creative and adaptive potential of the projective education system}

We assign to the structure of creative and adaptive potential of projective training the following components: motivational-orientation that determines the direction toward the goal and its achievement; cognitive that includes individual-perceptual, mnemonic, thinking strategies and tactics of solving actual tasks; emotional-volitional that describes emotional-imaginative experience and volitional regulation of creative quest plus perception of himself/herself as "the center of activity" in solving creative tasks; communicative that identifies the specificity of interpersonal communication, and ability to interact productively with a group while solving together creative tasks; reflexive that is a personal assessment of his/her capabilities, plus a process and results auditing. It is important to understand that the result of the future specialist's adaptation (i.e., a process of branching out into a new area of responsibility and social environment) is his/her social and cultural development as the most important mechanism of individual socialization 
(D. Andreev, S. Bezklubenko, L. Bueva, Y. Kulyutkina, A. Rean). It presupposes a personal active attitude and leads to personal changes (I. Miloslavova). The specific pedagogical studies attempt to determine "the adaptive skills" definition but in most of them, the authors only briefly address this problem (G. Ball, O. Gura, I. Zimnya, N. Kuzmina, etc.). Most authors (F. Berezin, M. Dmitrieva, L. Mitina, etc.) examine the professional adaptation in the context of the person's effective functioning. The adaptation is simultaneously a process of mastering a variety of social experiences and development of the new models of behavior, changing value orientations, the emergence of the new cultural needs, and interests.

Among the many educational functions, we focus on those that release his/her creative and adaptive potential. Thus, for keeping knowledge and information, and distribution (i.e., extension or transfer of information, or interconnection of knowledge) the following methods are effective: method of cases (active learning method based on the consideration of specific business situations, exceptional occurrences and cases, and aimed at the formation of the needed professional and personal qualities, skills, and capacities) ${ }^{33}$, case method, the method of specific situations, the method of situational analysis (a teaching technique that uses a description of real economic, social and business situations), in which the student has to be active, to achieve something or to discover, to create, to repeat, to shape skills. Also other functions are important such as control of understanding and students' actions as regards their accomplishment (made/did not made, procrastination, etc.); assessing the student's understanding and outcomes in order to identify the mistakes and problems (how well the student understands, how he/she succeeds); answers to the questions, explanations, interaction with a student or a group; assessment of the student's psychological state, his/her ability to overcome obstacles, detecting frustrations and problems; influence on the student's motivation to climb the steep hill; constant self-education, self-development, reflection and awareness of his/her problems.

There are plenty of methods that are based on the integration of creative-cognitive activities, which are divided into instrumental and personality methods. Instrumental methods provide a group problem solving and assist in searching a certain way in shaping his/her mental activities for solving a specific task; determine the algorithm of actions or

\footnotetext{
${ }^{33}$ Федорчук Е. І. Сучасні педагогічні технології. Кам’янець-Подільський : Абетка, 2006. С. 57.
} 
a set of general rules (heuristics) the usage of which helps get solution with sufficient probability. The instrumental methods include Brainstorming (A. Osborne), Synectics (W. Gordon), worksheets, "Morphological analysis" (F. Zwicky), the algorithm for solving inventive tasks, "Maieutics" (Socrates dialogues), CARUS (Combining Analogy Reconstructing Universal Strategy) a creative search method (V. Moliako), etc. The personality methods impact on personal behavior, build-up self-confidence, and stir feelings of his/her power raise awareness of the infinite opportunities of self-improvement in any sphere of life. These methods are designed for personal development training and aimed at strengthening the individual's ability to think autonomously and independently, developing special skills, and creativity. These techniques include: group dynamics (B. Holleran), transcendental meditation (F. Travis), method of developing personal integrity (R. Pivi), bodyoriented, cognitive, rational-emotive (A. Beck and A. Ellis), assertive technique, gestalt-technique, an awareness of the needs, etc. ${ }^{34}$.

In professional activities, communication plays a fundamental role and its effectiveness is interdependent with adaptive and creative processes. That fact presupposes the use of such an educational system that is aimed at building the socio-psychological competence. This competence implies the knowledge of group communication factors, understanding strategy and tactics of communication partners, mastering dialogue skills, and also the ability to use them in a specific communicative situation. Currently, the different methods of active social psychological learning (discussion, training, games, etc.) are freely distributed in the system of specialists training in those areas of professional activity, where the process of communication plays a leading role (Y. Yemelianov, V. Morgun, T. Yatsenko, etc.). In the broader sense of the word, the sociopsychological workshop is understood as the practice of psychological influence, which is based on active methods of group work. Such methods use original approaches for acquiring techniques in the sphere of communication, work, personal development, and correction, namely, mastering a certain socio-psychological knowledge related to the optimization of interpersonal communication, the development of communicative, reflexive and analytical abilities and skills, and increasing socio-psychological competence. In professional activities, communication plays a fundamental role and its effectiveness is interdependent with

${ }^{34}$ Костюченко О. В., Л. П. Дихнич. Психологія ефективності фахівця індустрії моди. Київ: Ліра, 2016. $464 \mathrm{c}$. 
adaptive and creative processes. That fact presupposes the use of such an educational system that is aimed at building the socio-psychological competence.

This competence implies the knowledge of group communication factors, understanding strategy and tactics of communication partners, mastering dialogue skills, and also the ability to use them in a specific communicative situation. Currently, the different methods of active social psychological learning (discussion, training, games, etc.) are freely distributed in the system of specialists training in those areas of professional activity, where the process of communication plays a leading role (Y. Yemelianov, V. Morgun, T. Yatsenko, etc.). In the broader sense of the word, the socio-psychological workshop is understood as the practice of psychological influence, which is based on active methods of group work. Such methods use original approaches for acquiring techniques in the sphere of communication, work, personal development, and correction, namely, mastering a certain sociopsychological knowledge related to the optimization of interpersonal communication, the development of communicative, reflexive and analytical abilities and skills, and increasing socio-psychological competence.

The creative and adaptive potential of training is released in the usage of such means and techniques which promote the acquisition of professional behavior skills particularly various types of reflections that form the basis for the development of self-regulation and selfimprovement abilities of the future manager. Among the reflexive environment organizational means, the game is the most commonly used method (that includes organizational-active, imitative, group dynamic, intellectual, and creative games) which promotes creative thinking and self-expression, self-analysis, and awareness of himself/herself as a person and individual and a specialist. Playing diverse and meaningful for learning situations and their analysis allow students to taste for themselves the whole psychological and pedagogical efficient and inefficient outcome of their actions.

The group debate and discussion are the leading teaching methods that allow participants to receive feedback from others, to determine a personal orientation and their self-evaluations, and a level of achievements, etc. The advantage of keeping a self-observation diary is evident in stimulating creative processes, reducing internal stress, training research skills and self-regulation. The results of the educational process are 
evaluated by reliable criteria of effectiveness: self-reports of the group participants (in response to the questionnaire); changing the perception of oneself and others.

The special classes are original and focus on gaining the personal experience of the diverse influences of various means, methods, and techniques. Among many techniques a significant emphasis has been placed on painting, modeling with color, form, perfumes, tastes, sounds, and images. The creativity is stirred up by a whole system of motives, and the central stimuli are following: an attempt to perceive and express his/her emotions and an experience in a visible form; the need to communicate with others using his/her products; he endeavors to study the surrounding world through the symbolization of it in a special form and to design the image of the world and the personal professional brand in the form of drawings, compositions of sounds, fragrances, shapes, colors, and holistic images.

We select the following essential factors of the efficient education, for instance: the level of object-subject relations in educational activities, when the subject is the one who teaches, seeks changes (Teacher, Lecturer, Coach, Tutor, Instructor, etc.), but the object of teaching is one who is taught, whom a teacher tries to transform (Pupil, Protégé, Follower, Superseder, Heir, Adherent, Admirer, Disciple, etc.); the level of individualization when one takes into consideration the peculiarities of perception, processing, interpretation and reproduction of information, fundamental properties of the brain, namely, neuroplasticity (the ability of remodeling under the influence of experience and as a response to external impacts $)^{35}$, which requires a certain number of repetitions for the development of sustainable skills; the level of integration of full-fledged perception of various modalities, logical and figurative, creative thinking, memory, emotions and states, and conscious bodily reaction; learning "in the context" and "by reality" a new information and opportunity to evaluate the action practice immediately after finishing it and to receive feedback; stimulating positive emotions, creating an atmosphere of approval, joy and trust; presence a teacher who provides: 1) the identification, evaluation, and analysis of the previous iteration's mistakes (an iteration means organization of data processing in which the actions are repeated again and again); 2) new data that are needed but it was not recognized before the evaluation of previous iteration's results;

35 Дойдж Н. Пластичность мозга. Потрясающие факты о том, как мысли способны менять структуру и функции нашего мозга: пер. с англ. Е. Виноградовой. Москва : Эксмо, 2012. 540 с. 
3) recommendations for correction of the efforts in accord with the purpose of the next iteration.

The normal process of learning is honest, responsible and result oriented, and unlike imaginary learning (marketing, politics, ideology, logistics), it is a project training ${ }^{3637}$. The key elements of project training are the sense (Why it is necessary? How does it change his/her life? Why it is necessary to invest my time and your time? What are the positive results? From what negative traits he/she will be get rid of?), the best motivation is understanding the sense of it; the goal (What specific result do you want to achieve within the framework of the project?) should be lucid, measurable and fixed by the date; the term of undertaking (to present the result by the specified date); tasks (What he/she has to do for achieving the goal?); resources (material, intellectual, etc.); shortage, difficulties and problems; action (What did the student accomplish? And what is the quality of his/her results?).

The project training contributes to (1) cultivating students' independence and eagerness in gaining knowledge and in learning, (2) modifying the meaning of interaction from subordination to cooperation and partnership, (3) the development of relevant professional skills and experience together with teamwork skills. The future specialist should learn to achieve a good quality result by the date fixed overcoming the shortage of resources.

Thus, in the project training such important principles of modern education are realized as the achievement of the result, growth of competitiveness and efficiency, promotion, where the focus shifts from the essential issues to personal communication. Therefore the role of the Teacher is reduced to mentoring, instructing rather than creating and communicating the content. The typical role of the Teacher expands, when besides the role of the content Creator and lecturer, the role of the Mentor is added that includes putting forth a task, examining and evaluating the results, explaining things in which the student displayed ignorance, interpreting cases, promotion, responsibility for the pace, content, and quality. Plus the mentor assumes the role of tracker that comprises responsibility for the consequences and the final productivity. As a result, the student creates or participates in the creation of an important outcome for him/her and the market/society.

\footnotetext{
${ }^{36}$ Бордовская Н. В. Гуманитарные технологии в вузовской образовательной практике: теория и методология проектирования. Санкт-Петербург : РГПУ им. А.И. Герцена, 2007. 384 с.

37 Колесникова И. А., Горчакова-Сибирская М. П. Педагогическое проектирование / Под. ред. В. А. Сластенина, И. А. Колесниковой. 3-е изд. Москва: Академия, 2008. 288 с.
} 
At the same time, the teaching of designing or project education is a means of constructing a designing method of interaction with the world as noted by well-known home scientists (V. Rubtsiv, V. Zimova, N. Nechaev, V. Sidorenko, etc.). One of the important tasks of educational system contemporary stage development is to build up students in understanding the project activity basics, and elements of the designing culture. For a future specialist the project training is the way for development of the personal creative potential and his/her self-realization; it is the developing environment that forms social abilities and skills plus facilitates the process of acquiring the life experience; it is functioning as a means for verifying the correspondence of the personal experience with the needs of a person to play an active role in society; it is acting as a creative report on the level of leadership competence.

Thus, it is possible to underline the following properties of the modern (relevant - important, essential, timely, appropriate) learning: accessibility, continuity, flexibility, productivity, competitiveness, focus on the development of pro-activity, initiative, and enterprise in a broader sense, and not just on mastering profession; it becomes: the most important valuable orientation; a way of achieving creative selfrealization and a high level of social hierarchy; leading daily and lifelong activity; traditional lecture format gives way to the project and problemoriented learning; changing models of education scaling (individual learning based on an individual plan and the availability of mentors for everyone will gradually replace the mass education); innovation of educational technologies (e.g., online education and the virtual environment, personification; modeling and prediction of a career based on the use of artificial intelligence, and Big Data approaches; a complete model of virtual reality, the maturity of a person and improvement of his/her cognitive abilities and possible cyborgization).

These properties will require the development and implementation of technologies: scalable, accessible, remote, full mentoring for everyone; likewise modeling and forecasting of an individual learning trajectory, which becomes synonymous with a career, in fact, it is modeling of destiny; further training protocols based on neuroplasticity are able to change the topology of the neuron network of the brain, and thus dramatically increase the speed and depth of training. 


\section{CONCLUSIONS}

In general, the analysis of scientific literature on the studies of this issue demonstrates that such specific direction of study and research as to the components of professional competence of the future specialists, namely, the ability to designing is insufficiently highlighted by both home and foreign authors and scholars.

Thus, we identified the main essential characteristics of the project activity such as (1) constructiveness and productivity, which contribute to the solution of vital problems and the achievement of the final result in the process of goal-setting, planning and implementation of the project; (2) a unique way of practice related to the prediction of the future, and creation of its ideal image including plan completion and evaluation of the consequences of accomplishing the plans; (3) the factor in the formation and development of specific design skills, namely, problematization (finding and formulating problems and tasks); (4) goal-setting and planning activities; (5) self-analysis and reflection (self-examination of the success and efficiency of project completion); (6) the presentation of the product activities; (7) selection and use of optimal technology for producing the designed product; (8) conducting the research (analysis, synthesis, putting forth a hypothesis, specification of details and generalization); (9) a tool for creating unique prerequisites for personal and professional selfdevelopment, the acquisition by the future specialists such skills as orienting in the educational sphere, generalizing theoretical knowledge and integrating it into professional skills, independent constructing and integrating his/her activities for achieving progressive innovations in the chosen professional environment; (10) one of the most promising components of the professional achievements as the specialists, when conditions for his/her creative self-development and releasing creative potential are constructed, professional competences are shaped, i.e., multicultural, linguistic, informational, political, socio-psychological, etc.

It is determined that the creative and adaptive potential of the project training 1 ) is released in the complex, dynamic and diverse psychological process of internal and external transformation of the motivational sphere and the usual forms and methods of activity, developing the needed complex of skills, abilities and habits for practicing new types of activities and turning them into a habit; 2) provides adaptation to the socio-cultural environment, adequacy, behavioral flexibility, accuracy of thinking, emotional balance and purposefulness. It is a prerequisite for releasing creative possibilities of the manager in a new, and unusual conditions. 
The perspective of further research. The main task of the future research is the construction of a model for the formation of professional competence of the future specialists in the conditions of higher educational institutions using psychological approaches based on the practical application of the modern model of education in foreign countries from the competent approach point of view.

\section{SUMMARY}

In the article, the essential features of the actual training of future specialists are theoretically analyzed. The factors of its efficiency, in particular, key elements, principles, functions, means, and methods of project training are examined, and especially the use of the method of projects from the competence approach point of view. It is found out that the creative and adaptive potential of the project training: 1 ) is released in a complex, dynamic and diverse psychological process of internal and external transformation of the motivational sphere and the usual forms and methods of activities; 2) provides adaptation to the socio-cultural environment, adequacy, behavioral flexibility, accuracy of thinking, emotional balance and purposefulness; 3) is a prerequisite for releasing the creative potential of a future specialist in a new and unusual conditions. The technologies of the project activity are mentioned. The main psychological and pedagogical purposes of project activity implementation are described by various types of studies on designing. The main components of the mechanism of implementation of the project technology are explained. They are conditions for self-realization of the specialist's personality, and development of his/her potential capabilities. Emphasis is placed on the fact that the implementation of the educational projects involves the integration of cognitive, research, gaming, and creative activities aimed at obtaining independent results in correspondence with psychological and pedagogical support.

\section{REFERENCES}

1.Барченков Д. А. Психологическое содержание профессиональной компетентности менеджера полифункционального холдинга. Вестник Тамбовского университета. Серия Гуманитарные науки. 2007. № 4. С. 199-206.

2. Бордовская Н. В. Гуманитарные технологии в вузовской образовательной практике: теория и методология проектирования. Санкт-Петербург : РГПУ им. А.И. Герцена, 2007. 384 с. 
3. Василевська Л. С. Проектна діяльність методиста як засіб удосконалення професійної майстерності педагогів [Електронний ресурс]. Наукові записки [Ніжинського державного університету ім. Миколи Гоголя]. Сер.: Психолого-педагогічні науки. 2012. № 6. Режим доступу: http://nbuv.gov.ua/j-pdf/ Nzspp _2012_6_32.pdf.

4. Власюк О. Проектна діяльність - перспектива розвитку особистості. Проектна діяльність у ліцеї: компетентнісний потенціал, теорія і практика / за ред. С.М. Шевцової, І.Г. Срмакова, О.В. Батечко, В.О. Жадька. К. : Департамент, 2008. 520 с.

5. Джонс Дж. Методы прогнозирования. М.: Мир, 1986. 524 с.

6. Дойдж Н. Пластичность мозга. Потрясающие факты о том, как мысли способны менять структуру и функции нашего мозга: пер. с англ. Е. Виноградовой. Москва : Эксмо, 2012. 540 с.

7. Срмаков I. Г. Феномен компетентнісно спрямованої освіти. Крок за кроком до життєвої компетентності та успіху. Київ: Лат і К, 2003. С. 6-8.

8. Життєва компетентність особистості / За ред. Л. Сохань, I. Срмакова, Г. Несен. Київ, 2003. 250 с.

9. Исаев И. Ф. Развитие профессионально-педагогической культуры преподавателя в условиях модернизации педагогического образования. Педагогіка та психологія. Харків, 2006. Вип. 29. С. 63-72.

10. Коберник О. М. Проективна педагогіка і національна школа. Шлях освіти. 2000. № 1. С. 7-9.

11. Ковальчук В. В. Сутнісно-змістовна характеристика категорії «професійна компетентність» як показника рівня фахової підготовки студентів. Проблеми інженерно-педагогічної освіти. 2007. № 18-19. С. 84-88.

12. Колесникова И. А., Горчакова-Сибирская М. П. Педагогическое проектирование / Под. ред. В. А. Сластенина, И. А. Колесниковой. 3-е изд. Москва: Академия, 2008. 288 с.

13. Компетентнісний підхід у сучасній освіті: світовий досвід та українські перспективи: Бібліотека з освітньої політики / Під заг. ред. О. В. Овчарук. Київ : «К.І.С.», 2004. 112 с.

14. Костюченко О. В., Л. П. Дихнич. Психологія ефективності фахівця індустрії моди. Київ: Ліра, 2016. 464 с.

15. Леонтьев А. Н. Деятельность. Сознание. Личность. Москва : Политиздат, 1977. 304 с.

16. Маркова А. К. Психология профессионализма. Москва: Знание, 1996. $308 \mathrm{c.}$ 
17. Осадча К. П. Аналіз понять «компетенція» та «компетентність» у зарубіжній та вітчизняній науковій літературі [Електронний ресурс]. Педагогічний дискурс. 2011. Режим доступу до ресурсу : file://C:/Users/Валера/Desktop/peddysk_2011_ 9_61\%20(2).pdf.

18. Панфілов Ю. І., Бондаренко В. В., Грень Л. М. Методика формування комунікативної компетентності майбутнього лідераменеджера. Теоретичні та прикладні аспекти дослідження феноменів лідерства, управління та розвитку сочіального об'єкта. 2016. № 2. C. 10-19.

19. Равен Дж. Компетентность в современном обществе. Москва: Когито-Центр, 2002. 395 с.

20. Тоффлер Е. Третя хвиля. Київ: Вид. дім «Всесвіт», 2000. C. 14.

21. Управління формуванням професійної компетентності магістрантів педагогіки вищої школи: теоретико-методичні засади : монографія. Київ : Дорадо-Друк, 2013. 456 с.

22. Федорчук Е. І. Сучасні педагогічні технології. Кам'янецьПодільський : Абетка, 2006. С. 57.

23. Хоружа Л. Проектна культура вчителя: етичний компонент. Шлях освіти. 2006. № 4. С. 11-15.

24. Хриков С.М. Педагогічні умови як складова наукових знань. Шлях освіти. 2011. № 2. С. 11-15.

25. Цимбалару А. Д. Семантика понятійного апарату проблеми педагогічного проектування. Нова педагогічна думка. 2009. № 3. C. 30-35.

26. Шарко В.Д. Моніторинг як одна 3 умов реалізації акмеологічного принципу в педагогічній освіті. Вісник Херсонського державного технічного університету. 2001. № 2.

27. Ягоднікова В. В. Кейс-метод (Case study) як форма інтерактивного навчання майбутніх фахівців. Секиія «Педагогічні науки», підсекція № 5. [Електроний ресурс]. Режим доступу : http://www.rusnauka.com/1_NIO_2008/Pedagogica/25496.doc.htm.

28. Dannefer, E. F. Peer assessment of professional competence [Електронний ресурс] / [E. F. Dannefer, L. C. Henson, S. B. Bierer, T. A. Grady-Weliky, S. Meldrum, A. C. Nofziger et al.]. Medical education. 2005. Режим доступу: https://www.researchgate.net/profile/ Ronald_Epstein/publication/7782103_Peer_assessment_of_professional_ competence/links/0deec51586e8070ae0000000.pdf. 
29. Definition and Selection of Competencies. Theoretical and Conceptual Foundations (DESECO). Strategy Paper on Key Competencies. An Overarching Frame of Reference for an Assessment and Research Program - OECD (Draft).

30. Epstein, R. M., Hundert E. M. Defining and assessing professional competence. American Medical Association. All rights reserved. 2002. № 2. P. 226-235.

31. Govaerts, M. J. Educational competencies or education for professional competence? Medical education. 2008. T. 42. № 3. P. 234-236.

32. Sturgis, C. Implementing Competency Education in K-12 Systems: Insights from Local Leaders. CompetencyWorks Issue Brie [Електронний ресурс] / C. Sturgis. International Association for K-12 Online Learning. 2015. Режим доступу: http://files.eric.ed.gov/fulltext/ ED557750.pdf.

33. Sandberg, J. Pinnington, A. H. Professional competence as ways of being: An existential ontological perspective. Journal of Management Studies. 2009. T. 46. P. 138-170.

34. Wimmers, P. F., Mentkowsk, M.. Assessing Competence in Professional Performance across Disciplines and Professions. Los Angeles, CA, USA: Springer, 2016. 473 p.

\section{Information about the author: Kostyuchenko O. V.} Doctor of Psychological Sciences, Associate Professor, Assistant Professor at the Department of Psychology of the Kyiv National University of Culture and Arts 
DOI https://doi.org/10.36059/978-966-397-112-4/101-119

\section{IRRATIONAL CONCEPT OF MANAGEMENT EDUCATION}

\section{Kovalenko Ye. Ya.}

\section{INTRODUCTION}

Having entered the 21st century, we began to live in a different world that we do not quite understand. If you accept this, then the following questions arise: How to understand the modern world, the world of business, politics, and culture? What are the criteria and mechanisms for the correct behavior of people and organizations in different situations? What are the tasks of leadership, building relationships, existence and management in the material and virtual spaces of this world, and many other things?

The answers to these questions are far from obvious. This is due to the fact that modern changes have acquired a new quality in society. They are characterized by extreme complexity, high speed, uncertainty and new opportunities and threats. However, the very person and his nature are poorly influenced and not always able to make such changes. In other words, all of these changes are difficult to manage, the risks of errors and wrong actions are multiplied.

If to decipher this statement, in the current reality management has faced serious problems. These problems are the gap between the essence of change and their perception, understanding, and, accordingly, the reaction to them. And as a consequence there are failures, crashes, bankruptcies, etc.

Why is this happening? In a book by well-known American researcher Jim Collins, "From Good to Great", the results of a fundamental study aimed at figuring out what factors provide companies with great results are presented. Conclusions are impressive. It turned out that the companies' success was not influenced by most of the management's components, which are traditionally considered as crucial ${ }^{1}$.

According to Professor of the Harvard Business School Clayton Christensen, literate management was the most important reason why leading companies were unable to stay on top of their industries; just

\footnotetext{
${ }^{1}$ Коллинз Д. От хорошего к великому. Пер. с англ. Санкт-Петербург : Стокгольмская школа экономики в Санкт-Петербурге, 2014. С. 18-34.
} 
because the managers did everything right they were defeated ${ }^{2}$. At the same time, many of those who did wrong and even absurd in the framework of the dominant management theory, and often without even having management education, they sought amazing success in their business development.

Therefore, it is necessary to agree that management in its classical sense, as science with its abstract-logical method, does not answer the questions posed by life, especially at present, in conditions of turbulence ${ }^{3}$. Such management became incapacitated, helpless, because it teaches to manage the organization by abstract rules. Now unconventional approach is needed. And first of all, one must rely on emotional intelligence, a professional sense and intuition. And this is a creativity and art.

The task of business management today is as something like "go there and I do not know where, and bring those I do not know what", but it is absolutely necessary for success. There is little logic here. This requires a completely different vision, talent. That's what a true management is. And if all is going according to old rules, different kinds of schemes, templates with a simplified vision of the object of management and it is no longer management. And so that future managers do not become hostages of illusory non-viable abstract management, the other should become management education. "We must," - observes Henry Mintzberg, "to prepare real managers, and not pretend that they can be made in the classroom" .

Modern pedagogy has accumulated considerable experience in training specialists in the management field. Important issues of the national model formation and the content of management education are disclosed in scientific works by N. Dalyuk, O. Elbrekht, M. Yevtukha, E. Kuznetsova, I. Shavkun, S. Shevchuk, L. Yankovskaya and others. Most of these works present the principles of construction and methodology of management education in Ukraine. And since the managers training involves taking into account fundamental knowledge from other fields, the subject of research by many scholars was the integration of knowledge from various disciplines.

However, the issues of modernization and adaptation of the national system of managers' educational training to the realities of modern

\footnotetext{
${ }^{2}$ Christnsen C. Innovator’s Dilemma. New York : Harper Business, 2013. P. 205.

${ }^{3}$ Мартинишин Я. М., Коваленко Є. Я. Формування сучасної системи управління життєдіяльністю суспільства. Вісник Київського національного університету культури і мистецтв. Серія: Менеджмент соціокультурної діяльності. 2018. Вип. 1. С. 7-24.

${ }^{4}$ Минцберг Г. Стратегический процесс. Пер. с англ. Санкт-Петербург : Питер, 2011. С. 184.
} 
society development remain insufficiently studied. This situation is unacceptable, as it leads to an increase in the number of inefficient people who are not in line with the challenges of the present, cannot identify problems and deal with them effectively, they are confused in different ways, why, what and how they should do; the number of inefficient organizations that cannot provide self-development in a changing environment is increasing; students wish to receive such education are decreasing in higher education institutions

In view of this, the purpose of our study is to justify the need to change the existing methodology of training managers and develop a new concept of management education, aimed at ensuring a high level of competitiveness of future managers in conditions of increasing uncertainty and turbulence. The methodological principles of the study were the dialectic principle of cognition, systemic, historical, cultural and synergetic approaches to the study of management and educational phenomena and processes, as well as the fundamental provisions of the management theory and management education development. To solve the tasks, general scientific, special and interdisciplinary research method were used: analysis, synthesis, induction, deduction, modeling, sociocultural, etc.

\section{The meaning of management education}

Having started to study this important problem, first of all, it is necessary to clarify the meaning of management education. In our opinion, it can be defined as the implementation of educational activities in order to increase the learner's competitiveness. We can argue that any educational process is more or less aimed at it. In fact, it is far from any. In most cases, even when there is a task of increasing the competitiveness of a future specialist, it is far from the primary. If it is about training managers, then competitiveness is the basis of the basics that determines the degree of their adaptability to the complex competitive conditions of the turbulent environment, and hence the ability to "survive".

Manager constantly faces competition in the external environment, and from how he manages to cope with it, depends on his success or, conversely, the failure. The manager has also always faced with internal competition in the organization, because he, on the essence of his activities, is on the career ladder, the promotion of which requires him not only a top-notch specialist, and an employee who can be the best in a competitive collision. 
In the case of a manager to be competitive means to act in such way that the competitive situations in which he is constantly developing in his favor or in the direction desired for him ${ }^{5}$. From this understanding, it follows that the manager's competitiveness is determined by two components: the situation and the action. It follows from this very important conclusion that without a deep understanding of the situation and the actions that are adequate to it, there can be no manager's competitiveness.

Consequently, management education should help the future manager to develop the capabilities that allow: 1) to understand the situations in which he finds himself; 2) to identify and carry out actions that make it possible to take winning positions in a competitive environment (fig. 1).

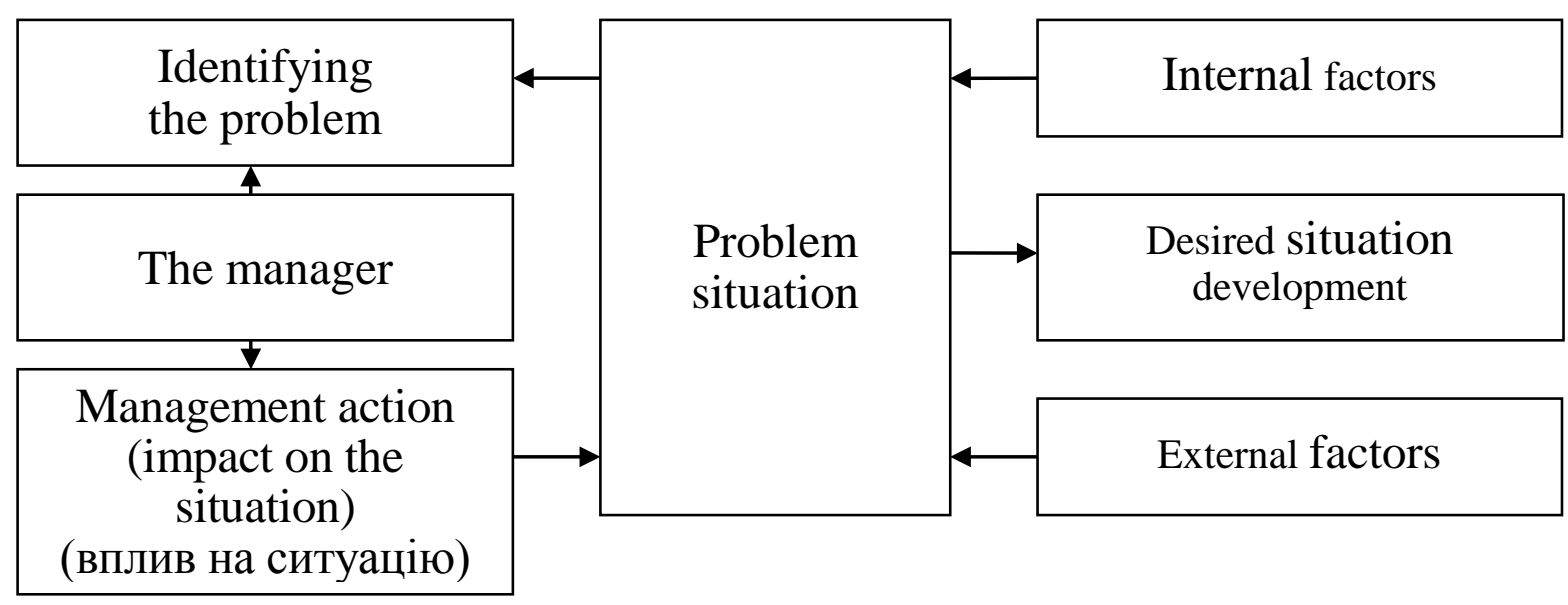

\section{Fig. 1. The mechanism of identifying} the manager's competitiveness

It is necessary to take into account that the management of a business organization has to deal not with the logic, but with people's interests. This is an extremely important position that you need to always be guided to be competitive in the business and career manager.

Traditionally, our education focuses on the specialists formation that is to prepare them for certain actions, in a well-known sphere of activity. More precisely it is about to train specialists for specific work within a particular profession and specialty. For this, person, who studies he or she must be given an idea (abstract and concrete, with a set of formal definitions and identifiable elements) about the subject of further activity

\footnotetext{
5 Мартинишин Я. М., Коваленко Є. Я. Смисли в культурі управління. Вісник Національної академї керівних кадрів культури і мистеитв. 2017. № 4. С. 26-31.
} 
and teach the adequate tools used in this subject area ${ }^{6}$. In other words, to provide him or her with complete information about the subject (traditionally called knowledge) and to help acquire the relevant skills and abilities that are, conventionally speaking, specialty attributes.

Formation of a specialist in one or another qualification in this case is the main task of the educational process. Incidentally, this very approach to the education understanding is currently dominant in our education system. Although it should be noted that recently due to the transformation in the education system there was a transition to the socalled competent approach. This clearly indicates that the reforms are aimed at modernizing the education system, bringing it closer to a state that meets the requirements of a post-industrial society.

However, it should be emphasized that neither competency nor qualification approaches fully correspond to the essence of management education.

Management is by no means a specialty and even a profession in the classical sense of these terms. This is a specific area of activity that is predominantly situational in nature. In order to succeed in this field, the actions of the individual should be, rather, art, distinguished originality and even uniqueness, namely, it is often carried out in a different way. Since the subject of activity is characterized by enormous diversity, it is impossible to describe it not only thoroughly, but at least approximately. It is more or less clear which minimum set of knowledge should be learned and what skills should be acquired. But all this is just some qualifying minimum, which does not give grounds for achieving the desired results of real activity in the manager's status.

The ability to understand the situation, to see the hidden driving forces, to understand people and to identify the springs, which set the power and direction of the situation, require from the individual much more than the presence of his qualifications of a specialist or certain competences. He should have a set of some individual personal qualities, abilities; helps to reveal and strengthen what can, and consequently, should be management education.

It is appropriate to note here that in the light of the said by managers there are not all those who are engaged in management activities or they are business owners. The majority of managers are managers and most business owners and just owners, investors and even not entrepreneurs.

\footnotetext{
${ }^{6}$ Мартинишин Я. М., Коваленко С. Я. Мистецтво управління й освітні технології підготовки менеджерів соціокультурної діяльності. Біла Церква : Вид. Пшонківський О. В., 2018. С. 78-79.
} 


\section{The most important skills of a successful manager}

The great thinker and artist, one of the few prominent geniuses of humanity, Leonardo da Vinci, distinguished seven qualities that are needed for self-expression and self-development: curiosity; test yourself a real experience; sensitivity; acceptance of uncertainty; thinking harmony; feeling of your body; perception of reality ${ }^{7}$. As we see, here it is not about any qualifications or competencies, but about such qualities as the ability to penetrate the essence of phenomena, processes, and people, to seek harmony within them and with the outside world, to be creative and original. It is quite obvious that our education does not develop these abilities, and may even drown oneself from those who have more or less them, but do not find them in the learning process.

From the position of training managers, these qualities are basic, namely, it is necessary for a very competitive manager. They are usually of a universal nature and do not relate to any particular type of activity. Perhaps in other spheres of activity their role may not be as significant, but it can hardly be overestimated in its management.

Great Leonardo da Vinci created 500 years ago. Of course, the creative fruits of his genius are not subject to time. But it's important to keep in mind that the world is constantly changing. In a couple of centuries after the da Vinci era, Europe entered the industrial era. The masters' time has gone. Instead, a specialized qualified worker has come in. Differently began to look at what is necessary for professional success. This led to significant transformations in education, the masters changed specialists and, it seemed, the ideas of Leonardo da Vinci remained in the past. However, the world continued to change, relations between people began to be filled with new content, business and other spheres of human activity in their tasks became increasingly sophisticated and refined in terms of methods of their vision, as well as the tasks solved by it. At the turn of the XXI century with great speed for decades (and not hundreds and more than thousands of years, as before) not just significant changes began to occur, but there were global transformations. Naturally, there was an adjustment and a set of key qualities that form the potential of the individual, on the basis of which he can achieve the desired result.

Daniel Pink, author of the bestseller series on business world issues, has formulated six abilities for success in the 21st century. The most important among them are: the ability to see meaning, to realize what is

\footnotetext{
${ }^{7}$ Gelb M. How to think like Leonardo da Vinchi: seven steps to genius every day. New York : Dell Publishing, 2011. P. 41-43.
} 
being done, to understand the purpose as development; ability to design on the basis of feelings; ability to go beyond logic, use emotions and intuition; the ability to capture and persuade by a story; the ability to manifest humor, to bring gaming moments into business; the ability to think broadly and creatively, do not hang on the details ${ }^{8}$.

Obviously, in the XXI century these six abilities are quite clearly correlated with those that distinguished Leonardo da Vinci. Now we see that the industrial era goes back into the past and returns the masters' era with a strong emphasis on the individualization of creativity and the backbone of hidden in man's abilities and the soul's quality. Speaking of Pink's ability, it should be noted that there is a noticeable emphasis on quality, characterizing the emotional, artistic side of the individual's behavior. The rational basis of behavior undoubtedly goes to the background; the basis of success is the emotional intelligence. It follows the obvious conclusion: the current conditions management education largely is focused on assisting the manager in the future emotional intelligence development in order to better engagement in practice.

In the last decade, one of the most popular concepts for the development of managers' key qualities is the concept WIST, nominated by John van Maurik (WIST name is related to the fact that English words that denote these qualities begin with these letters). According to this concept, a successful manager has such qualities: wisdom; integrity; sensitivity; tenacity ${ }^{9}$.

This concept, as we see, does not affect either the knowledge of the manager or the field of his professional qualifications. The manager's success is based on individual qualities that characterize his ability to build a relationship on a positive basis with people, relying mainly on emotional-sensory aspects of his behavior. The presented concept has had a strong influence on the management education development, pushing it towards the strengthening of the focus on the interpersonal intelligence development and ethical behavior.

Summarizing best practices in leadership positions it has enabled us to formulate our own concept of key abilities that allow individuals to be successful in the role of manager (tab. 1).

\footnotetext{
${ }^{8}$ Pink D. A whole new mind why right brainers will rule the future. New York : Riverhead Books, 2015. P. 109-110.

9 Maurik J. The effective strategist: key skills for all managers. Albershot : Gower Publishing, 2009. P. 67.
} 
Key abilities of a successful manager

\begin{tabular}{|c|c|}
\hline Types of abilities & Characteristic \\
\hline $\begin{array}{l}\text { Alternative } \\
\text { vision }\end{array}$ & $\begin{array}{l}\text { The ability to deeply penetrate the very essence } \\
\text { of various situations, processes, phenomena, be } \\
\text { able to notice and understand the invisible ones } \\
\text { (new possibilities, threats, tendencies) and } \\
\text { intuitively predict their development }\end{array}$ \\
\hline $\begin{array}{l}\text { Non-standard } \\
\text { thinking }\end{array}$ & $\begin{array}{l}\text { Ability to deviate from traditional thinking } \\
\text { patterns, go beyond the limits of logic, beyond } \\
\text { the limits of the visible and be able to think } \\
\text { divergently, irrationally, a logically, } \\
\text { nonlinearly, critically, emotionally, intuitively }\end{array}$ \\
\hline Creativity & $\begin{array}{l}\text { The ability to continually change, differentiate } \\
\text { and produce fundamentally new, unusual ideas } \\
\text { and bring them to a concrete practical result in } \\
\text { the form of a variety of attractive things. }\end{array}$ \\
\hline Communicativeness & $\begin{array}{l}\text { Artistry, emotionality, sensitivity, ability to } \\
\text { build and develop relationships, persuade, } \\
\text { induce empathy, influence freedom, } \\
\text { consciousness and feelings }\end{array}$ \\
\hline $\begin{array}{l}\text { Orientation } \\
\text { in chaos }\end{array}$ & $\begin{array}{l}\text { Ability to navigate and quickly solve complex } \\
\text { problem situations in conditions of chaos } \\
\text { (unsystematic, disorderly, disorganized, insta- } \\
\text { bility, variability, uncertainty, turbulence, etc.) }\end{array}$ \\
\hline Obsession & $\begin{array}{l}\text { Emotional-volitional state, which manifests } \\
\text { itself in the complete self-forgetfulness of } \\
\text { devotion to the cause and persevering in self- } \\
\text { sacrifice, intent on reaching the goal, over- } \\
\text { coming any obstacles and difficulties }\end{array}$ \\
\hline Confidence & $\begin{array}{l}\text { The property, the core of which is the positive } \\
\text { assessment of their own abilities, skills and } \\
\text { abilities, as sufficient to achieve significant } \\
\text { ("impossible") goals and success }\end{array}$ \\
\hline
\end{tabular}


The most important of these is an alternative vision. And if the manager has such ability, then he should be called not just a manager, but a "visionary".

Therefore, analyzing the issue of failures and crashes of successful companies, not to mention mediocre, it should be noted that the reason for their failure was not bad strategies or inadequate updating, etc. The companies' failure was the result of the leaders' actions, largely due to their vision. And if to speak more precisely it is the absence of such.

The German irrational philosopher, Arthur Schopenhauer, has a pretty figurative statement: "Talent hits a target that nobody can touch; a genius hits a target that nobody sees”10 (Tab. 1).

Management of a business organization is an extremely complex process, especially in modern conditions and it is constantly getting more and more complex, more and more sophisticated. Therefore, an alternative vision as the ability to look into the very essence of the relationship, as the ability to look at tomorrow from day after tomorrow, to see and understand the invisible and it is a key ability on the basis of which managers can achieve positive results in various spheres of society's life.

An alternative vision is a very delicate matter, which has no explicit and unambiguous attributes. It is impossible to give universal measurements, by means of which one can uniquely identify such a vision, the extent of its manifestation. However, the presence of a vision can be said when someone is able to achieve results that it is considered impossible to achieve. At the same time, it is difficult to explain to a stranger how he succeeds.

You can point out what is typical for managers who have an alternative vision. First, they pursue "impossible" goals. Secondly, they are obsessed with devotion. This is a deep devotion to the people, the company chosen by the case. Thirdly, they are obsessed with. Under critical conditions, they become even more obsessed with, more mobilized for solving problems. Fourth, they are characterized by deep insight in people's perception and evaluation. Management is people, people and only people. People have opportunities, people are at risk and people are the source of strength and people are a source of weakness. Therefore, a deep understanding of people, the ability to feel the person is the most important visionary's quality. Fifthly, an alternative vision is not without the ability to deviate from traditional thinking patterns, go beyond the limits of logic, beyond the visible and the ability to think divergently,

\footnotetext{
${ }^{10}$ Шопенгауэр А. Афоризмы житейской мудрости. Пер. с нем. Москва : ЭКСМО, 2016. С. 216.
} 
irrationally, a logically, non-linearly, critically, emotionally, intuitively, since all these are the main tools of vision. Therefore, non-standard thinking is a hallmark of managers who have vision.

Of course, the vision itself does not produce a result. Real actions are needed. But it is precisely through vision that the manager can build his actions in such a way that they will lead to the desired result. And here the very important quality of a manager is his ability to navigate and quickly solve difficult problem situations in conditions of chaos: unsystematic, disorderly, disorganized, uncertain, etc. The manager should consider such situations not only as a mess in which it is impossible to carry out activities, but on the contrary it is as a more complex and less accessible understanding order, and being confident and able not to get lost in such situations, be able to see them new opportunities and to promptly apply adequate actions to realize the opportunities identified in favor of their cause.

Manager's creativity and communicative skills of the are also very important features: his ability to constantly produce new ideas and the ability to build and develop relationships, which in harmony with the previous qualities allow you to achieve great results in the career of the head of the organization.

In our understanding of management education should not only promote the expansion of all these skills, but above all be aimed at their development. It is important that today the world education system has some necessary set of methodical techniques and pedagogical tools that allow students to provide effective assistance in developing these qualities. Most of these approaches and techniques of learning are unique. They are not only very different from traditional education methods, but often they are diametrically opposed.

However, it is often heard from many business executives that the main disadvantage of graduates who have received management education it is their complete lack of ability to disclose and identify problems. And this is the most important task of the manager, because in fact the problems hide different opportunities for business. According to company executives, even if higher education institutions train welleducated young people who know and know a lot, they do not give them the most important thing: an understanding of the processes taking place in business, especially the ability to see problems, to dig into their true causes, and already then to offer possible solutions. 
Instead graduates (unfortunately this applies especially those welllearned) come with ready-made answers. They were taught the correct answers at universities and for which they received positive marks for learning.

Businessmen are well aware that catastrophic mistakes are assumed when there is a ready response and thus a deeply unprocessed problem.

The question arises: why universities do not develop students' ability to disclose and identify problems? The answer lies on the surface. In most academic disciplines, problems and tasks have been defined, formulated and described. Therefore, the student's main focus is on studying the methods of solving already formulated tasks. At the same time, very little attention is paid to the issue of limiting the use of the proposed methods outside the audience.

As a result of this training, students firmly believe in the universality of the methods they have studied and believe that they have acquired the ability to solve if not all, then most of the real problems. This is just one of the most significant shortcomings of the existing management education in Ukraine.

\section{The contours of the modern concept of management education}

The essential feature of the academic areas of society is its ambivalence. On the one hand, it is the most important source of change, renewal, development and mankind progress. On the other hand, this area is very conservative, hardly prone to change. Therefore, there is a paradox: education and science as social institutions push society forward, but they themselves barely make fun of those changes in social life that arise at an accelerated pace.

Business is one of the most rapidly evolving sectors of society. It is in the business of breakthroughs that rely exclusively on the achievement of scientific thought. Business transposes the society, converting it from one stage to another. Therefore, in the field of management education there is the greatest need for updating, in bringing its methodology and technology to the needs of a business that is constantly changing. And this suggests that management education is largely a source of development in the field of education in general.

A change in the concept of learning should take place now. The educational process of an industrial society focuses on the question: "what?" and "how?". Therefore, the task of the education system, 
adequate to the needs of this type of society, is the training of employees of a specific specialty and qualifications (tab. 2).

The educational concept of a post-industrial society should focus on the learning process on the question: “why?" and "for what?". And this puts forward the main tasks of the educational process and it is raising the overall level of the future manager's development and a certain type of behavior formation in him.

The first concept is focused on the transfer of subject knowledge (in fact, it is the transfer of systematic information over individual academic disciplines) and the development of certain skills and abilities that correspond to a given model of qualification, that is, one who learns must know and be able (often complemented by the formula "able to apply in practice”) (Tab. 2).

Table 2

Priorities concepts of management education

\begin{tabular}{|c|c|c|}
\hline $\begin{array}{c}\text { No. } \\
\text { of p }\end{array}$ & Existing concept & New concept \\
\hline 1 & Management is a science & Management is an art \\
\hline 2 & $\begin{array}{c}\text { Development of abstract-logical } \\
\text { Individual Intelligence (IQ) }\end{array}$ & $\begin{array}{c}\text { Emotional development } \\
\text { Individual Intelligence (EI) }\end{array}$ \\
\hline 3 & $\begin{array}{c}\text { The main task of the educational } \\
\text { process: the transfer of subject } \\
\text { knowledge and the of skills and } \\
\text { competence development that } \\
\text { correspond to a given model of } \\
\text { manager qualification }\end{array}$ & $\begin{array}{c}\text { The main task of the } \\
\text { educational process: a certain } \\
\text { model formation of behavior } \\
\text { and the alternative abilities } \\
\text { development that provide } \\
\text { success in the role of manager }\end{array}$ \\
\hline 4 & $\begin{array}{c}\text { The learning process is deployed } \\
\text { in the past (outdated theories, } \\
\text { secrets, experience) with an effort } \\
\text { to design } \\
\text { this is the future }\end{array}$ & $\begin{array}{c}\text { The learning process is } \\
\text { deployed in the future with an } \\
\text { effort to design "tomorrow" } \\
\text { from "the day after tomorrow" }\end{array}$ \\
\hline 5 & $\begin{array}{c}\text { The main forms and sequence of } \\
\text { learning: first, a lecture (the } \\
\text { theory of a particular subject } \\
\text { field), and only then - a practical } \\
\text { lesson }\end{array}$ & $\begin{array}{c}\text { Basic forms and sequence of } \\
\text { learning process: first practical } \\
\text { lesson and only after that - the } \\
\text { theoretical substantiation of its } \\
\text { implementation (lecture) }\end{array}$ \\
\hline
\end{tabular}


Table 1 (continuance)

\begin{tabular}{|c|c|c|}
\hline 6 & $\begin{array}{c}\text { The technology of training is } \\
\text { formal, } \\
\text { with a focus on memorizing the } \\
\text { material without understanding } \\
\text { the action, its scheme and } \\
\text { structure; learning is through } \\
\text { repetition of the correct answers } \\
\text { to the question "how?", "what?", } \\
\text { and to a lesser extent - "why?" }\end{array}$ & $\begin{array}{c}\text { Teaching technology is } \\
\text { informal - learning by action, } \\
\text { with a detailed explanation of } \\
\text { its scheme and structure; } \\
\text { learning occurs mainly } \\
\text { through the formulation of the } \\
\text { correct questions "why?", } \\
\text { "what for?", and only then - } \\
\text { the search for the answer } \\
\text { "how?" }\end{array}$ \\
\hline 7 & $\begin{array}{c}\text { The training microclimate is } \\
\text { mostly passive }\end{array}$ & $\begin{array}{c}\text { The learning microclimate: } \\
\text { creative activity, interest }\end{array}$ \\
\hline 8 & $\begin{array}{c}\text { Learning results are obtaining } \\
\text { unfamiliar book knowledge } \\
\text { information) that predominates } \\
\text { with practice; disappointment }\end{array}$ & $\begin{array}{c}\text { Learning results are the } \\
\text { formation of their own } \\
\text { knowledge and personal } \\
\text { experience, which coincide } \\
\text { with the practice and even } \\
\text { ahead of it; pleasure }\end{array}$ \\
\hline
\end{tabular}

The second concept of education is aimed, conditionally, on the upbringing of the future manager, the certain model formation of behavior in it. The student's development of specific abilities is characterized for this type of educational concept, instilling him adequate values, proper standards of behavior, the needs of creative activity, a firm understanding that the basis of all is precisely the activity.

And this cannot be achieved by simply transmitting systematized information and acquiring some set of skills (through traditional lectures and seminars). There is a need in group work on projects, immersion in real practical activities, visiting workshops of authoritative people, that is, filling the learning process with the creative and emotional context. This is what distinguishes between management educations, at least its component, which is the methodology of learning.

Does this mean that individuals self-development in the educational process of managers does not involve the assimilation of certain systematic information, commonly referred to as knowledge, or the development of professional skills and abilities? The answer is obvious of course, no. 
Education cannot go without expanding student awareness without receipt of representations, definitions, concepts etc. Also, it will be incomplete without the mastering of a number of operations and a certain set of actions. Undoubtedly, all this is needed, but not the main thing.

In the modern world, the necessary information can always be obtained through the means of accessing data arrays. Moreover, information in terms of its relativity and utility is constantly obsolete. And technologies used in the management sector are also developing at a very high pace. Therefore, now all this is no longer the main component of managerial education. At the initial stage of its formation, knowledge and skills were at the center of the educational process. Now they must be replaced by personal characteristics, emotional intelligence, real activity and, above all, its moral and ethical side.

The world-famous scientist-psychologist Howard Gardner, author of the monograph "The Framework of the Mind: Theory of Multiple Intelligence" (1983), which has made a truly revolutionary breakthrough in the understanding of intelligence, and as a result, in the realization of the essence of education, came to the conclusion that in the modern world higher intelligence is interpersonal intelligence.

Daniel Goleman in super bestseller "Emotional Intelligence: Why it can mean more than IQ" Gardner cites the following statement: "A lot of people with a mental development rate of 160 work on those who do not have this coefficient to exceed 100 if the first low interpersonal intelligence and the others are high. In everyday life there is no higher intelligence than interpersonal. Namely, we just need to teach children at school to use their mental abilities ${ }^{11}$.

In modern life, especially in management, the ability to use their emotional intelligence, as well as the ability to understand, feel and use the emotions of others, there are powerful sources of competitiveness, and, therefore, the key factors of success in life. Emotional intelligence underlies the creation, development, destruction of relationships and interactions between people. And, then, its development and use should be at the center of managers' education. However, the real educational process is aimed primarily at the development of rational mental abilities (it refers to the logic, logic of thinking and behavior), the improvement of emotional abilities is practically excluded from the tasks of learning.

\footnotetext{
${ }^{11}$ Гоулман Д. Эмоциональный интеллект: почему он может значить больше, чем IQ. Пер. с англ. Москва : Манн, Иванов и Фербер, 2015. С. 74.
} 
In the case of management education, such state of affairs is unacceptable in principle, because management is based not on logic, but on the people's interests. On the whole, real life does not fit into the logic. There is Johann Goethe's figurative expression: "the being is not divisible by the mind without the leftover"12.

Professor Duke University Dan Ariel, who received widespread worldwide appreciation after the publication of the bestseller "Predictably irrational"13, in his well-known monograph "The Positive Side of Irrationality" writes: "Of course, it would be great if we were more rational and clearly imitated what should be done. Unfortunately, this is not the case. How else can it be explained the fact that millions of membership cards for sports clubs have been purchased for health purposes and they have not been used. Or the risk to which many impose themselves and the environment by sending text messages while driving a car. It can be endless. It follows that it is incorrect to assume that people are absolutely intelligent computer. On the contrary, we observe how people behave, and our observations often lead us to conclusion that people are irrational”14.

At the end of the monograph, he has reached such conclusion as to the many manifestations of our irrational behavior: "We have a lot of persistent irrational manifestations; we often do not know how these inefficiencies affect us and therefore do not realize the full extent that determines our behavior" 15 .

The above means that it is necessary to learn (it is especially important for managers) to succeed in conditions of irrationality, that is, to develop in yourself those qualities that rely on emotional intelligence. But traditional education, which is deployed in the past, manipulates abstract symbols, proceeds from the primacy of absolute impartiality, it is aimed at neutrality in communications, often written, and it does not contribute to this intelligence development.

In the transition to a new concept of managerial education the most important element of learning should be the development of the ability to solve the problem and formulate the problem, the solution of which should lead to the elimination of the problem. Communication is through the formulation of "right" questions, not by repeating "correct" answers. Training is based on the experiment mainly in the form of group work on projects.

\footnotetext{
${ }^{12}$ Гете И. В. Избранные сочинения по естествознанию. Пер. с нем. Молсква : Наука, 1975. С. 43.

${ }^{13}$ Arieli D. Predictably irrational. New York : Harper Collins, 2012. 354 p.

${ }^{14}$ Arieli D. The upside of irrationality. New York : Harper Collins, 2014. P. 6.

${ }^{15}$ Ibid. P. 288.
} 
Of course, it is impossible to exclude traditional teaching methods such as group discussion, analysis of specific situations, doing tests and homework assignments in writing essays. But all this, together with the creative experimental activity, it must necessarily finish with reflection, the student's answer to the question: "what has changed in me?", "what did I begin to see differently?”, “what have I not yet achieved?”. That reflection is an indicator of whether there was training.

It is important to understand that the training of managers through the acquisition of knowledge in the form of systematic information and, moreover, in the form of fragmentary information is very often not only useless, but dangerous as it creates an illusion of development. Of course, in this case it is not about useless, harmful or false information. It is about correct and, as many people think, the information needed for education. After all, knowledge, in its essence, has a double character. It is possible to understand life, mostly looking back. But life moves only forward. Itfollows that knowledge simultaneously helps and hinders adequate inclusion in the life process. There is a metaphor based on knowledge, we seem to be moving forward in the car, looking at the rear view mirror. If the road is relatively flat, then it is possible. But on a winding road, which is a modern life, it will always lead to failures, and even to disasters. You can avoid failures by lowering the speed of movement, but such a decision is in itself a source of disaster.

One more point is connected with the fact that management is creativity, art. And, as it is known, true creativity goes beyond the plane of "right-wrong". And finally, it's important to understand that the more we know, the greater the space of our ignorance. So, we need to move in the space of wisdom, but knowledge does not provide such an opportunity.

\section{CONCLUSIONS}

The results of the study suggest the following conclusions:

Under current conditions of profound fundamental changes, uncertainty and turbulence, management faced a serious problem, which is to break the essence of these changes, their perceptions, understanding and reaction to them. This problem cannot be solved until the managers' actions are based only on rational perception of the management object, abstractions and logic, outdated theories and past experience. To solve it, managers must first of all be art, differ in originality and be carried out often in a different way. 
There is an existing management education in Ukraine, although it prepares competent young people, and it does not give them the most important: an understanding of the processes taking place in society, especially the ability to see problems, to dig into their true causes and to propose possible solutions. The educational process is oriented on the abstract logic intelligence development and the memory of the material without understanding the action. Learning occurs through repetition of right answers. Learning is through the repetition of the correct answers. And as a result to get book knowledge, which mostly runs out of practice.

The meaning of management education is to conduct educational activities to increase the competitiveness of the student. It is a measure of manager adaptability to difficult competitive environment and ability to survive. To be competitive means to be able to grasp the situation, to see the hidden driving forces, to understand people and to find springs that set the power and direction of the situation, and act in such a way those competitive situations develop in the desired direction. Without a deep understanding of the situation and adequate actions, there can be no manager's competitiveness.

Global transformations and the gradual departure in the past of the industrial era lead to a return to the era of masters with a strong emphasis on the individualization of creativity and the reliance on the hidden and human capabilities and qualities of the soul. The rational basis for the manager's behavior and the usual knowledge (competencies) goes into the background. The basis of success is not the abstract-logical, but the emotional artistic abilities that allow deep irrationality to penetrate into the essence of processes, deviate from traditional patterns of thinking, see, feel and understand the invisible ones and act adequately.

New management education should not only promote the development of these skills, and above all be aimed at their development. In this regard, the learning process should be oriented towards the development of non-abstract-logical intelligence and the memory of the material without understanding the action, and emotional intelligence and learning action. It must be deployed in the future, not the past, and with the effort to design "tomorrow" from "the day after tomorrow". The training should take place through the right questions formulation, rather than through the repetition of the correct answers. And as results to acquire own knowledge and personal experience that will coincide with the practice and even surpass it. 


\section{SUMMARY}

The necessity of developing the new concept of management education due to global transformations of organizational reality and new requirements for the work of managers is considered. The meaning of management education has been revealed. The most important capabilities of the individual have been determined, guaranteeing him success in the role of manager. The main contours of the newest concept of managerial education are considered, taking into account the irrationality of the modern world. It is indicated that the educational process should be oriented towards the development of emotional intelligence and learning by action. It must be deployed in the future. Training should take place through the formulation of the right questions. As a result, the future manager will have his own knowledge and personal experience that will coincide with the practice and even surpass it.

\section{REFERENCES}

1. Коллинз Д. От хорошего к великому. Пер. с англ. СанктПетербург : Стокгольмская школа экономики в Санкт-Петербурге, 2014. 295 c.

2. Christnsen C. Innovator's Dilemma. New York : Harper Business, 2013. 318 p.

3. Мартинишин Я. М., Коваленко Є. Я. Формування сучасної системи управління життєдіяльністю суспільства. Вісник Київського національного університету культури $i$ мистецтв. Серія: Менеджмент соиіокультурної діяльності. 2018. Вип. 1. С. 7-24.

4. Минцберг Г. Стратегический процесс. Пер. с англ. СанктПетербург : Питер, 2011. 353 с.

5. Мартинишин Я. М., Коваленко С. Я. Смисли в культурі управління. Вісник Національної академї керівних кадрів культури $i$ мистеитв. 2017. № 4. С. 26-31.

6. Мартинишин Я. М., Коваленко Є. Я. Мистецтво управління й освітні технології підготовки менеджерів соціокультурної діяльності. Біла Церква : Вид. Пшонківський О. В., 2018. 374 с.

7. Gelb M. How to think like Leonardo da Vinchi: seven steps to genius every day. New York : Dell Publishing, 2011. 186 p.

8. Pink D. A whole new mind why right brainers will rule the future. New York : Riverhead Books, 2015. 329 p.

9. Maurik J. The effective strategist: key skills for all managers. Albershot : Gower Publishing, 2009. 267 p. 
10. Шопенгауэр А. Афоризмы житейской мудрости. Пер. с нем. Москва : ЭКСМО, 2016. $640 \mathrm{c.}$

11. Гоулман Д. Эмоциональный интеллект: почему он может значить больше, чем IQ. Пер. с англ. Москва : Манн, Иванов и Фербер, 2015. 560 c.

12. Гете И. В. Избранные сочинения по естествознанию. Пер. с нем. Москва : Наука, 1975. 412 с.

13. Arieli D. Predictably irrational. New York : Harper Collins, 2012. 354 p.

14. Arieli D. The upside of irrationality. New York : Harper Collins, 2014. $302 \mathrm{p}$.

\section{Information about the author:} Kovalenko Ye. Ya.

$\mathrm{PhD}$ in Economics, Associate Professor, Associate Professor at the Department of Art Management and Event Technologies of the National Academy of Supervisory Frame of Culture and Arts 9, Lavrs'ka str., Kyiv, 01015, Ukraine 


\section{CONDITION OF DEVELOPMENT AND PROBLEMS OF MODERN EDUCATION FOR ADULTS}

\section{Maslianikova I. V.}

\section{INTRODUCTION}

Population aging is a world process. The proportion of older persons in the population is growing rapidly in developed countries and many developing countries. Ukraine is and will remain for the next few years one of the "oldest" countries in the world. It is projected that in 2051 the share of persons older than 60 years will be about 33\%. Naturally, this situation predetermines the need to allocate resources to support the older generation.

Adult education is a phenomenon characteristic of highly developed countries. Its feasibility is a generally accepted fact. The progressive ideas of this world sociocultural phenomenon are reflected in the documents of international organizations. Thus, the Hamburg Declaration of the UNESCO world conference (1997) States that "adult education is the key to the twenty-first century". The problem of adult development is defined as a priority problem in the international educational environment. Its special value was noted during the meetings of the "Big eight" (the Charter of Cologne, Cologne, 1999; "Education in a changing world" (Final document of the meeting of education Ministers of the "Big eight", Tokyo, 2000). Masatsuka of the agreement made at the meeting of the Global compliance program "Education for all" (2014) significantly influenced the justification of the goals in education proposed by the Working group of the open-ended goals of sustainable development ${ }^{1}$.

The main consumer in the field of adult education becomes an individual with its specific educational needs, then social groups, social institutions, including the state, and society as a whole. This determines the requirement of breadth and flexibility of the system, its adaptation in all respects (place, time and terms of training, variety of programs, certification levels), as well as the use of special technologies of adult education as consumers of educational services.

Often adult education is seen as narrowed as education to ensure pure economic growth and increase the population's chance of employment. However, the mission of education in general, adult education in particular,

\footnotetext{
1 Лук'янова Л. Законодавче забезпечення освіти дорослих: зарубіжний досвід. - Вид-во: ТОВ «ДКС-Центр»- К., 2007. - С. 5.
} 
is much broader and is to attract citizens to a full-fledged multi-faceted social life and not only in the labor market. After all, the need to learn throughout life reflects much more than just an economic need, because education is increasingly playing a key role in restoring stability, dynamic development of society, and its civil, professional, domestic spheres. Adult education in all its dimensions - formal, informal, informal - is aimed at self-development of the individual and, accordingly, should be supported at the state level. This approach, together with the guarantee of the individual's right to education at any age, is the basic norm of legislation in progressive European States. We hope that in a rapidly developing Ukrainian society, the European principles and values regarding the adult education system will become a Ukrainian reality.

Thus, the Concept of development of adult education in Ukraine (2011) emphasizes the need to recognize adult education at the state level as an integral part of the national education system and the development of new approaches to its legal regulation, especially the need to prepare a draft Law "On adult education» ${ }^{2}$.

\section{The historical aspect of the development of adult education}

Historical intelligence suggests that the first officially recorded documents that normalize adult access to education are:

- creation of the first adult school (Nottingham, UK, 1798);

- budget of a special article on subsidies "people's peasant schools", which were the prototype of the people's high schools in Denmark (Denmark, 1852);

- adoption of the law on public education, aimed at supporting the creation of evening and Sunday classes for adults who have not received education or seek to improve their knowledge (Spain, 1857);

- recognition of adult education and the responsibilities of the state to support it (Constitution of the Weimar Republic, 1919).

It is worth mentioning that one of the first books on adult education "The History and development of adult schools" was published in 1816, the author of which was Dr. T. Pole ${ }^{3}$.

Theoretical analysis of literary sources proves that in the west, adult education in the early twenty-first century exists in two major forms: European and American. The history of adult education in the United

2 Лук'янова Л.Б. Концепція розвитку освіти дорослих в Україні. - Ніжин: ПП Лисенко М.М., 2011. $-24 \mathrm{c}$.

3 Лук'янова Л. Законодавче забезпечення освіти дорослих: зарубіжний досвід. - Вид-во: ТОВ «ДКС-Центр» - К., 2007. - С. 6. 
States has its own traditions. So, in 1964 in the USA there were only 16 educational programs for adults. Although the first Department of adult education was established in 1920 in the UK, but only in the 60s of the last century in the Anglo-Saxon civilization there was a sharp increase in the importance of adult education as a special field of academic research.

In 1986, the first international conference on the history of adult education was held at Oxford University, where scientists from great Britain, other countries of Europe, North America and the East and Japan worked. In 1989, at the University of Syracuse (USA), canadian and American scientists implemented a project aimed at analyzing the relationship between vocational education and adult education.

Historical analysis shows that in 1919 the World Association for adult education in London was founded, which functioned before the Second world war. Since 1949, UNESCO has been constantly updating the problems of development of the international movement in the field of adult education. International symposia on adult education were held in Elsinore (Denmark,1949), Montreal (Canada, 1960), Tokyo (Japan, 1972), Paris (France, 1985) and Hamburg (Germany, 1997).

Among the leading humanistic trends in the development of adult education we define the development of national adult education systems in leading European countries, its reform and modernization in the second half of the twentieth century, the development of methodological foundations of continuing education in the EU at the present stage and in the process of their historical formation. However,according to scientists, different interpretations of the methodology of comparative research in the field of adult education, in particular - categories, laws, functions, philosophy, interdisciplinary approach, methodology of andragogics, scientific knowledge, scientific research, development of adult thinking, need to be coordinated.

\section{General provisions of adult education}

Adult education is a social institution historically formed. It is a complex multifunctional socio-psychological-pedagogical and sociocultural system aimed at meeting the professional,educational and personal needs of a person.

Adult education is based on the theory of adult education-andragogy, scientific and methodological basis of which is the technology of adult education. It is also based on the concept of free, "open-education", the 
psychology of adult education, developed in the context of continuous human education throughout life.

In the scientific turnover generally used theoretical and methodological foundations of adult education are the following positions.

An adult student is a person of capable age, socially mature, in general, a personality is formed, which in different ways combines educational activities with employment in the field of paid work. For her, training is not the main activity, because it occurs simultaneously, in parallel with another activity (professional, etc.), family life ${ }^{4}$.

Adult education is a purposeful process of development and education of the individual through the implementation of educational programs and services, the implementation of educational and information activities within and outside the general secondary, vocational, higher and postgraduate education ${ }^{5}$.

The content of adult education due to the goals and needs of society requirements for the system of knowledge, skills, worldview and social and professional qualities of a specialist, formed in the process of andragogically oriented training with the prospects of development of science, technology, technology and culture. The purpose of the adult education system is the realization of the human right to education during life ${ }^{6}$.

The main objectives of the adult education system are:

- to meet the needs of the individual in intellectual, cultural and spiritual development through continuous education;

- formation of students' citizenship, ability to work and live in the conditions of modern civilization, its democratic development;

- preservation and enhancement of moral, cultural and scientific values of the society; dissemination of knowledge among the population;

- raising its cultural and educational level ${ }^{7}$.

Functions of the adult education system:

- adaptive-adaptation to the new requirements of life in a society that is dynamically changing;

\footnotetext{
${ }^{4}$ Анциферова Л. И. Психологические закономерности развития личности взрослого человека и проблема непрерывного образования [Текст]. Психологический журнал. 1980. Т. 1. № 2. - С. 52-60.

${ }^{5}$ Там само.

${ }^{6}$ Бабич М.С. Безперервна освіта (освіта впродовж життя) - умова підвищення національної конкурентоспроможності. / Вісник Хмельницького національного університету 2015, № 5, Т. 1.: [Електронний ресурс]. - Режим доступу: http://yandex.ua/clck/jsredir.

Лук'янова Л. Концептуальні положення освіти дорослих: [Електронний ресурс]. - Режим доступу: http://yandex.ua/clck.
} 
- compensating-reproduction of educational opportunities that were previously absent or lost;

- developing-enrichment of activity opportunities of the person and his spiritual world;

- analytical-research and analysis of factors affecting the need of citizens for continuing education,

- transformative-changes in the educational and qualification level of a person throughout life, as well as the intellectual and cultural level of society;

- prognostic-scientific prediction of the development of personality and society;

- communicative-transfer of social experience from generation to generation;

incentive-stimulation of educational needs of the person ${ }^{8}$.

Principles on which adult education is based:

- recognition of the right to education at any age as one of the leading fundamental human rights;

- orientation of adult education on universal values and ideals of humanism;

- systematic development;

- the continuity;

- accessibility of education;

- interaction and partnership of state bodies, non-governmental and public organizations;

- taking into account the specific educational needs of different categories of adults;

- state support for adult education ${ }^{9}$.

Adult education is characterized by:

- public nature of management;

- variability of programs and terms of training;

- combination of forms of scientific and applied knowledge;

- the voluntary nature of the training;

- systematization of training;

- purposeful activity of those who study;

- focus on meeting the educational needs of individual social and professional groups;

8 Громкова М. Т. Андрагогика: теория и практика образования взрослых: учеб. пособ.: [Електронний ресурс]. - Режим доступу: http://yandex.ua/clck/jsredir. - Загол. з екрану. - Мова укр.

9 Лук'янова Л. Концептуальні положення освіти дорослих: [Електронний ресурс]. - Режим доступу: http://yandex.ua/clck. 
- creating a comfortable educational environment for adult communication; changes ${ }^{10}$.

- possibility of psychological protection in the conditions of social

Main types of adult education:

- formal education, which ends with the issuance of a recognized diploma or certificate;

- non-formal education is carried out in educational institutions or public organizations (clubs), as well as during individual lessons with a tutor, coach and is usually not accompanied by a document;

- informal education is an individual cognitive activity (life experience) that accompanies everyday life and is not necessarily purposeful $^{11}$.

Forms of adult education:

- full-time (fixed - with a margin of production for a certain period of training in educational or educational-professional program;

- evening (shift) - on-the-job training for the period of education or educational and professional program with attendance during the study in his spare time;

- part-time-without interrupting production for a period of training in educational or educational-professional program attend classes during training, during installation and examination sessions;

- external - a special form of on-the-job training, which provides for the independent study of academic disciplines of educational or vocational education programs, the preparation of the final control tests in an educational institution;

- distance learning - is a special form of on-the-job training that provides for the study of educational disciplines of an educational or vocational education program using computer and telecommunication technologies, the preparation of the final control tests in an educational institution;

- under pedagogical patronage - a form of education of persons with special social needs;

- through self-education - a form of non-formal education through the assimilation of educational programs with minimal organization of the educational process or without the guidance of this process on the part of teachers;

\footnotetext{
10 Психологические проблемы образования взрослых [Електронний ресурс]. - Режим доступу: http://www.voppsy. ru/issues/1989/892/ 892005.htm.

${ }^{11}$ там само.
} 
- combined-form - that integrates all the various forms and their elements ${ }^{12}$.

\section{State of development of the problem of adult education in Ukraine}

According to the statistics of adults enrolled in formal and non-formal education, in the early XXI century in the countries of the European Union exceeded 37\%. For example, in Sweden $73 \%$ of the population are involved in adult education, in Norway and Finland -55\%. Ukraine in terms of the level of participation of the adult population in various educational programs belongs to the fourth, the last group of countries in which the number of adult citizens who study is less than $15 \%$.

Adult education in Ukraine is carried out within the legislative framework defined by the Basic law, the framework Law "On education" and other laws, which to a certain extent relate to education ("On General secondary education", "On out-of-school education", "On vocational education", "On higher education", "On scientific and technical activities"), and normative legal acts regulating the education of the ablebodied (employed and unemployed) population. In these and other legislative acts adopted over the past two decades, the ideas of creating conditions for the development and self-realization of the individual during life are declared and normalized.

Currently, the basis of adult education is post-graduate education, financed from the state budget in the amount of $1.0-1.3 \%$ of the total budget for education. These funds are used to improve the skills and retraining of graduates. At the same time, they are not enough to ensure a minimum, at least once every five years, systematic training of workers in all economic activities. The analysis of the situation showed that there are no systematic proposals for the provision of educational programs for adults, taking into account their personal needs, capacity, age. Grant support from the state and local budgets of those organizations and institutions that provide adult education has not been developed, and the activities of international donors are too complicated. In general, there is a lack of financial support and promotion of adult education in the country, in particular through tax breaks, direct payments for adult education and the like. So, often-densely adult education is a personal

\footnotetext{
12 Психологические проблемы образования взрослых [Електронний ресурс]. - Режим доступу: http://www.voppsy. ru/issues/ 1989/ 892/ 892005.htm.
} 
matter and responsibility, its role is not properly understood at the level of public policy.

Among the omissions and miscalculations in the development of adult education is primarily to determine the following:

- the lack of legislative and regulatory framework that specifies the purpose, objectives, functions of adult education, regulate the activities of the subjects of the educational process, their rights and obligations, the nature of interaction with the state, coordination mechanisms between the subjects of management, as well as the principles and forms of financing, and as a consequence, the uncertainty of the status of adult education in society, which hinders the development of an integrated system of education during life;

- uncertainty of the role and tasks of Central and local Executive authorities and local self-government bodies in ensuring interaction between state institutions, non-governmental organizations and social partners in the field of adult education;

- lack of systematic recognition and certification of formal, nonformal and informal adult education, the key component of which is the system of accreditation and evaluation of previous experience, acquired personal competencies;

- the lack of structure of the Ministry of education and science, youth and sports of Ukraine of units of sufficient capacity, necessary for the development, coordination, quality control of adult education.

At the same time, an empirical study was conducted in four districts of Kyiv (Pechersk, Darnitsky, Desnyansk and Podolsk), which was attended by more than 400 people aged 18 to 70 years, showed that the need for adult education is extremely high. Research of citizens was conducted during 2019 in the pension funds of these areas, social services and on the streets of the city. The survey was conducted with the help of the actually developed questionnaire, which consisted of 12 questions aimed at determining the demand for adult education, its content, orientation, features of its implementation and popularization of information about the possibility of adult education. The results of the study showed that the attitude of citizens to adult education is positive, even interested. Respondents of different ages (from 18 to 70) gladly answered the questions and showed a caring attitude to the development and implementation of adult education in Ukraine.

The overwhelming majority of respondents are women (83\%). By age range the subjects were distributed as follows: 18-35 years (17\%), 
36-60 years (25\%), 60-60+ (58\%). The vast majority of the adult population has higher education - 67\%. Identification of the characteristics of the marital status of respondents showed that only $31 \%$ of the subjects are married, the rest: divorced (19\%), widows/widower (28\%), unmarried (22\%).

Determination of the professional orientation of the studied according to the classification of $\mathrm{O}$. Klimov showed that half of them belong to the profession "man-man" - 52\%; the rest were distributed as follows: "man-technology" - 28\%, "man-artistic image" - 8\%, "mannature" $-6 \%$, "man-sign system" - 6\%.

The data obtained showed that $56 \%$ of the respondents have already taken (or are currently taking) part in non-formal educational programs, $44 \%$ of the respondents are not involved in adult education due to lack of information or time. However, $81 \%$ of citizens expressed an urgent need for new knowledge and $75 \%$ of them have a desire to receive education free of charge.

The main purpose of training is self-improvement (61\%), orientation in the modern world (33\%) or further professional activity (6\%). In response to this question, $71 \%$ of respondents chose two of these items. Regarding the form of training, the vast majority of the study $72 \%$ preferred full-time form of education and only $28 \%$ of respondents distance (using computer and telecommunication technologies).

At the same time, $84 \%$ of respondents are focused on formal education, which provides for the certification of knowledge in the form of a certificate or diploma of the state sample. Convenient time for adults day training (64\%). The results of the study of the areas of adult education that are of interest to citizens turned out to be interesting. It turned out that the following branches of knowledge are leading: the new computer technologies (work on the Internet, including social networks) - 30\% and psychology (personal growth training) - 28\%. The rest of the proposed professional areas have up to $5 \%$ of the respondents is elections - transport industry, hotel or tourism, foreign languages, traditional medicine, law and hand-made. Thus, empirical data allow to orient in features of providing educational services to the adult population.

In a free conversation, it was found that the greatest popularity of adult education in the age group $60+$ is due to many factors, such as retirement, loss of family and friends, illness and as a result - the narrowing of the circle of communication and areas of activity. Therefore, adult education for people of advanced age in addition to the above functions can act as a compensatory mechanism in a situation of lack 
of attention and communication. Thus, adult education can resume its importance in the social environment, provide an opportunity for new useful acquaintances and find yourself in a new professional field.

The results of the research formed the basis for the development of training «Modern methods of adult education» in the framework of professional development of the adult which were held at the Taurida national University named after V.I. Vernadsky. Training and work with adults allowed to find out the psychological portrait of an adult student and psychological features of their training.

So, let's focus on the most significant:

- an adult student has a leading role in the learning process. This means that the listener independently determines the zone of the nearest development;

- an adult student has life experience (social, professional), which can be used as an important source of education;

- the education of an adult student is aimed at solving an important life problem and achieving a specific goal;

- an adult student is counting on the immediate use of the knowledge and skills acquired in training (urgency of training);

- the educational activity of an adult student is largely determined by temporal, professional, social factors that limit or contribute to the learning process;

- the learning process of an adult student should be organized in the form of joint activities of the student and the person who teaches at all stages of planning, implementation, evaluation and, to some extent, correction into account the individual approach;

- training of an adult student is characterized by a conscious assessment of the result as a personal neoplasm, which is achieved through its own activity;

- training of an adult student provides for the acceptance by the student of responsibility for their own actions, the result of which is not known in advance;

- an adult student strives for independence in the learning space.

The methodology of adult education must take into account the following positions:

- identify the request of students and take it into account as much as possible in the work;

- set the rules of work and be sure to follow them;

- promote group cohesion and to maintain the working momentum; 
- the material is submitted clearly and structured with the possibility of teacher's explanations and students' comments;

- use of a combined approach to the forms and methods of training (theoretical material with practical exercises, static with mobile activities, individual with group activities, etc.);

- features of communication in the adult learning space should include techniques of active and passive listening, feedback, application of discussion and willingness to hear criticism;

- features of interaction between the teacher/coach of the adult should be based on a partnership, the teacher should act as a tutor/ facilitator/consultant. Relationships should be based on trust and respect for each other.

Features of assimilation of educational material by adult students is characterized by the following:

- the quality of mastering the material depends on the psychophysiological, individual psychological, age, gender characteristics of students and their professional activities;

- awareness of the material (its understanding, the ability to verbalize and apply in practice) increases depending on the acquisition of the status of necessity, importance, novelty, creativity for a particular listener;

- the interest of students is an indicator of teaching (if necessary, it is necessary to adjust the teaching style, content, sequence of presentation, methods and form of training, etc.);

- assessment in the training of adult students becomes important through the ability to evaluate their work on certain criteria, others and certainly teaching.

Factors affecting the learning process of adult students:

- ease of teaching - the material should be accessible to the understanding of each student;

- versatility - the material should be commented on from different sides, not only by the teacher, but also by students with examples from their professional activities;

- flexibility - taking into account the logical and psychological sequence in the supply of material;

- "tasks to home" - tasks are more performed in the classroom.

The most effective were the following teaching methods:

- analysis of practical situations,

- group discussion,

- entertainment business games, 
- the solution of design problems,

- project development,

- brainstorming,

- training exercises.

Therefore, it can be argued that there is a need to address the current challenges facing adult education, but adult education is a factor that provides a direct process of development of the individual and society as a whole. At the same time, the best way to develop adult education in Ukraine should take into account both the specifics of the Ukrainian mentality and the trends of modern world experience.

\section{Priorities for the development of adult education in Ukraine}

In order to develop and implement the state policy in the field of adult education, it is necessary to legislate the requirements for coordination and interaction of various subjects of activity from the systematic and consistent implementation of this education, the recognition of the human right to lifelong education, access to educational and information resources of all kinds.

First of all, at the state level, it is necessary to recognize the public usefulness of adult education and to consolidate guarantees of its development through the allocation of special budget items, the development of methods of financial support for the most "remote" from the education system of social groups; ensuring the availability of educational services for all adults, regardless of age, level of previous education, place of residence, social status. Special attention should be paid to adult education by the state administration, local self-government bodies and public organizations, in particular in the field of non-formal and supplementary adult education.

In order to increase the interest of organizations in the allocation of funds for training, retraining and advanced training of personnel and counteract the trend of savings on training of employees, it is advisable to develop a legal mechanism to stimulate both employees and employers regarding continuous professional and personal improvement. Systemic cooperation between the Executive authorities, the state employment service, line ministries and agencies and employers should play an important role in the implementation of such a mechanism.

The legal framework should reflect the requirements for teaching staff and educational and material resources of organizations, planning and accounting of educational work, qualification growth and career 
advancement of personnel, as well as financing the cost of professional training of workers in both production and non-production areas. Regulation of the financing of staff development costs should include, inter alia, the procedure for determining the current educational and administrative costs of educational institutions.

The issue of reliable state statistics on adult education at the local, regional and national levels is important.

In our opinion, it is necessary to develop adult education as an integral system that reproduces the guarantees and rights of every citizen of the country for lifelong learning; to orient it to universal values, the ideals of humanism; to harmonize the interests of the individual and society, as well as to make the mentioned education accessible to all segments of the population, to create objective conditions for the maximum development of the individual, the realization of all personal potential opportunities, which will contribute to both successful adaptation to changing socioeconomic conditions and social protection of an adult.

In order to implement the state policy in the field of adult education, it is advisable to ${ }^{13}$ :

1. Adopt the Law of Ukraine "On adult education" and relevant bylaws.

2. To secure guarantees for the development of adult education through the allocation of special budget items, the development of a mechanism of financial support for the most "remote" from the education system of social groups, ensuring the availability of educational services for all adults, regardless of the level and direction of previously acquired education, income and place of residence, age and health status.

3. Consider the possibility of a significant expansion of the postgraduate education sector of the Ministry of education and science, youth and sports of Ukraine, including its powers and functions on the coordination and management of the adult education system.

4. To include in the national classifier of Ukraine: Classifier of professions the profession of an andragogist and implemented in higher educational establishments to train personnel for the needs of the labour market and adult education.

5. To introduce a system of real economic incentives for employers to develop and implement professional training of personnel of enterprises, organizations and institutions.

13 Лук'янова Л.Б. Концепція розвитку освіти дорослих в Україні. - Ніжин: ПП Лисенко М.М., 2011. $-24 \mathrm{c}$. 
6. To implement measures to regulate the education and employment of persons with disabilities, to justify the list of integrated professions for the training of persons with disabilities in a modular system of vocational training institutions for professions that are in demand in the labor market.

7. Develop non-formal education for older persons. To this end, to provide comprehensive support from public administration and local selfgovernment bodies for the establishment and operation of associations and interest groups; to stimulate the activities of non-governmental public, sponsor organizations that have joined or are willing to join the implementation of the project "Universities of the third age".

Thus, taking into account the above, it should be emphasized that only a systematic attention to the problems of adult education, a clear national strategy in this area will be able to turn Ukraine into a modern civilized democratic state, where the interests and needs of each person are the concern of the state and society.

\section{CONCLUSIONS}

In the context of the structural restructuring of the economy and the active transition of the our country to market conditions, taking into account the positive foreign experience, the ability and willingness of the population of our country to adapt to new and unexpected situations is becoming increasingly important, which determines the feasibility of the concept of adult education.

Adult education is the process of personal, social and professional development of a person throughout his life, which is implemented in order to improve the quality of life of both the individual and society as a whole. This comprehensive and unifying idea covers formal, non-formal and informal learning; it is embodied in order to achieve the development of all spheres of human life at different levels.

Adult education should be based on the principles of openness, selfdevelopment on the basis of new principles focused on socio-economic changes in society, the existence of differences between educational and professional activities of adults. Flexible learning paths, recognition, certification and accreditation are important in adult education.

Prospects for the development of adult education in Ukraine:

- adoption of the new law "On education" (definition of adult education as an integral part of the lifelong education system); 
- definition with approaches to management (and financing) of formal and non-formal adult education at the state, regional, city/ district levels;

- development and adoption of the bill "On adult education";

- inclusion of adult education in regional and local development plans;

- formation of public opinion on adult education and education.

\section{SUMMARY}

The article presents modern views on adult education in Ukraine and abroad. The article outlines the actual problems of the adult educational space, the historical aspect of the problem, the essence of adult education, its purpose, objectives, principles, functions, forms and types of adult education. The article presents an empirical study devoted to the study of the demand for adult education in Kiev, its content, features of the implementation and promotion of information about the possibility of adult education. The materials also contain the results of practical experience in the training program "Modern methods of adult education" on the basis of Taurida national University named after V.I. Vernadsky, which are identified during the psychological characteristics of adult education. The article also outlines the shortcomings and prospects of development of adult education in Ukraine. The article may be of interest primarily to scientific and pedagogical workers of higher educational institutions, as well as representatives of the general public who seek to improve the quality of adult education in Ukraine.

\section{REFERENCES}

1. Анцыферова Л.И. Психологические закономерности развития личности взрослого человека и проблема непррывного образования [Текст]. Психологический журнал. 1980. Т. 1. № 2. - С. 52-60.

2. Бабич М.С. Безперервна освіта (освіта впродовж життя) умова підвищення національної конкурентоспроможності. / Вісник Хмельницького національного університету 2015, № 5, Т. 1.: [Електронний ресурс]. - Режим доступу: http://yandex.ua/clck/jsredir.

3. Громкова М. Т. Андрагогика: теория и практика образования взрослых: учеб. пособ. [Текст]. М.: Юнити-Дана, 2005. - 495 с.

4. Давидова В.Д. Методичні рекомендації щодо використання шведського досвіду неформальної освіти дорослих у вітчизняній педагогічній практиці. - Б: ББТ НАУ, 2007. - 43 с. 
5. Державний комітет статистики України. Офіційний сайт державної служби статистики [Електронний ресурс]. - Електронні текстові дані. Режим доступу: http://www.ukrstat.gov.ua.

6. Закон о внесении изменений в Закон об обучении взрослых. [Электронный pecypc]. - Режим доступа: http://estonia.news-city.info/ docs/sistemse/dok_iegzez.htm

7.Закон об обучении взрослых. [Электронный ресурс] (РТ И, 1998, 71, 1200). - [Электронный ресурс]. - Режим доступа: http://rup.ee/rus/pdf/zakoninarusskom/30.pdf.

8. Закон України «Про освіту». [KElektronnij resurs]. - Rezhim dostupu: http://zakon2.rada.gov.ua/laws/show/1060-12.

9. Каган М. С. Системное управление образованием взрослых в условиях модернизации: монография в 3-х т. / Каган М.С., Е.Н. Князева, С.П. Курдюмов; науч. ред. А.И. Жилина. - СПб.: ГНУ ИОВ РАО, 2007. - Т. 2. - 188 c.

10. Колесникова И.А. Основы андрагогики: учеб. пособ. [Текст] / И. А. Колесникова, А. Е. Марон, Е. П. Токоногая. - М.: академия, - 2003. - 240 с.

11. Конституція України. - [Електронний ресурс]. - Режим доступу: http://zakon2.rada.gov.ua/laws/show.

12. Концепція освіти дорослих в Україні / Укл.: Лукянова Л.Б. Ніжин: ПП Лисенко М.М., 2011 - 24 с.

13. Кулюткин Ю.Н. Психология обучения взрослых [Текст]/ Ю. Н. Кулюткин. - М., - 1985. - 128 с.

14. Лук'янова Л. Законодавче забезпечення освіти дорослих: зарубіжний досвід. - Вид-во: ТОВ «ДКС-Центр»- К., 2007. - С. 4.

15. Лук'янова Л. Концептуальні положення освіти дорослих: [Електронний ресурс]. - Режим доступу: http://yandex.ua/clck.

16. Модельная программа подготовки андрагогов: учеб.-метод. пособие / Н.Н. Кошель [и др.]; под. ред. Н.Н. Кошель. - Минск: АПО, 2011. - $314 \mathrm{c}$.

17. Мониторинг непрерывного образования: инструмент управления и социологические аспекты. Сер. «Мониторинг. Образование. Кадры» / Науч. рук. А.Е. Карпухина. М.: МАКС Пресс, 2006. - $340 \mathrm{c}$.

18. Муниципальное образование для взрослых. - [Электронный pecypc]. - Rezhim dostupu: http://www.government.se/sb/d/6997/a/ 67936.

19. Образование взрослых - ключ к XXI веку. - Екатеринбург: УГПУ, 2001. - $173 \mathrm{c.}$ 
20. Образование взрослых на рубеже веков: вопросы методологии, теории и практики: в 4 т. - Спб.: ИОВ РАО. - Том 1: Социально-экономические и правовые предпосылки развития образования взрослых. Книга 2: Политика в области образования взрослых / Под ред. В.И. Подобедова, Н.П. Литвиновой. - 324 с.

21. Образование: Сокрытое сокровище: Доклад Международной комиссии по образованию для XXI века, представленный ЮНЕСКО. - Издательство ЮНЕСКО. - 1996 - [Электронный pecypc]. - Режим доступа: http://www.ifap.ru/library/book201.pdf.

22. Образование взрослых как социальный институт / под ред. Е.П. Тонконогой, В.И. Подобеда. - СПб. : ИОВ РАО, 1999. - 216 с.

23. Обучение взрослых: учиться никогда не поздно // Коммюнике Комиссии Европейских Обществ, Брюссель, 23 октября 2006 года. КОМ (2006) 614 окончательный [Электронный ресурс]. Режим доступа: http://www.google.com.ua/url?sa=t\&source=web\& $\mathrm{cd}=1 \&$ ved $=0$ CB.

24. Освіта дорослих в Україні через призму європейського досвіду: збірка матеріалів. - DVV international. - Київ, 2011. - 117 с.

25. Психологические проблемы образования взрослых [Электронный peсурс]. - Режим доступа: <http://www.voppsy.ru/ issues/ 1989/ 892/ 892005.htm.

26. Развитие психологических функций взрослых людей [Текст] / под ред. Б. Г. Ананьева, Е. И. Степановой. - М., - 1977. - 200 с.

27. Сікорський П.І. Теорія і методика диференційованого навчання: монографія [Текси]. - Л.: Сполом, - 2000. - 421 с.

28. Система неперервної освіти: здобутки, пошуки, проблеми. Чернівці, 1996. - 234 с.

29. Гадзирадієва С.К. Навчання дорослих як наукова проблема [Електронний ресурс]. - Режим доступу: 23.02.2008: http://www.lips.zp. ua/index.php?option=com_content\&view=article\&id=264:120032\& c atid $=47$ :states \&Itemid $=79$

\section{Information about the author: Maslianikova I. V.}

Candidate of Psychological Sciences, Associate Professor, Associate Professor at the Department of Psychology and Pedagogy of the Educational and Scientific Institute of Humanities of the V. I. Vernadsky Taurida National University 


\section{THEORETICAL AND METHODOLOGICAL APPROACHES TO DEFINING THE SUBJECT OF THE METHODS OF TEACHING HUMANITARIAN DISCIPLINES AT HIGHER SCHOOL (AS EXAMPLIFIED BY THE MULTICULTURAL EDUCATIONAL MODEL)}

\section{Nediukha M. P.}

\section{INTRODUCTION}

The search by modern university science for ways of establishing the multicultural educational model is associated, as it is known, with established paradigms of scientific knowledge - classical, non-classical and post-non-classical ones, a new worldview in the unity of its natural, social and cosmic bases. It is evident that there is a need for synthesis of theoretical and methodological research attitudes that would overcome the cognitive, heuristic limitations of traditional, established approaches through the latest, non-traditional ones, which allows, in particular, to substantiate the subject of the methods of teaching humanities in higher education in accordance with the requirements of the multicultural educational model as the process of teaching and learning that is based on democratic values, contributes to the development of cultural pluralism in the multicultural, interdependent world ${ }^{1}$, promotes the movement toward goals and ideals, which are not achievable in full ${ }^{2}$. We are talking about the possibilities of combining in the educational process two crucial educational and cultural traditions - the natural sciences one and the humanities one with the prospect of a possible synthesis of the fundamental laws of nature and space, society and man in the globalized socio-cultural space.

1. The curr ent state of scientific development of the problems of studying the methods of teaching humanitarian disciplines and its subject

The issues of the content of the educational process, its construction, the structure of the course of academic disciplines are actively discussed in scientific and methodical literature; they find both theoretical

\footnotetext{
${ }^{1}$ Bennett C. I. Comprehensive multicultural education: Theory and practice / C.I. Bennett. Boston: Allyn \& Bacon, 1999. - 345 p.

${ }^{2}$ Banks J. A. Multicultural Education: Characteristics and Goals / J.A. Banks // Multicultural Education: Issues and Perspectives. Wileys \& Sons, 2003. - P. 3-31.
} 
development and implementation in the practice of the educational process of higher education. The specified area of scientific research is necessarily promoted by the clearness of the scientific community about understanding the object of studying the methods of teaching as a learning process ${ }^{3}$ or a pedagogical process ${ }^{4}$. Dialogue between representatives of different intellectual and cultural traditions ${ }^{5}$, creative discussions ${ }^{6}$, critical thinking ${ }^{7}$, being components of the multicultural educational model, contribute to reducing the gap between science and education, deepen understanding the content of academic disciplines ${ }^{8}$, organizational forms and methods of learning ${ }^{9}$, new information and communication technologies in the system of higher education ${ }^{10}$, the place, role and purpose of electronic textbooks and teaching aids in the educational process $^{11}$, draw attention to research that embodies modern trends of educational change ${ }^{12}$, the dynamics of modernization of the educational process ${ }^{13}$, ways of approaching the European educational

3 Нелеп А. Т. Теоретические проблемы методики преподавания философии. Киев: «Вища школа», 1973. - С. 19.

4 Мойсеюк Н. С. Педагогіка : навчальний посібник. Вид. п’яте, доп. і перероб. Київ: ВАТ «Білоцерківська книжкова фабрика», 2007. С. 256.

5 Андрущенко Т.В. Ціннісний дискурс цивілізацій: монографія. Київ: Університет «Україна», 2011. $-440 \mathrm{c}$.

6 Дмитренко М. А. Наука і освіта як невід'ємна складова механізму реалізації стратегій інноваційного розвитку суспільства // Науковий часопис НПУ імені М. П. Драгоманова. Серія 22. Політичні науки та методика викладання соціально-політичних дисциплін. 2009. Випуск 2. - С. $24-33$.

7 Недюха М. П. Критика як теоретико-пізнавальний та діалогово-полемічний конструкт конституційно-правового мислення // II Всеукраїнські правові наукові читання пам'яті доктора юридичних наук, професора, заслуженого юриста України, член-кореспондента Національної академії правових наук України Ніни Романівни Нижник: збірник матеріалів / за заг. ред. А. Є. Шевченка. Вінниця: ТОВ «ТВОРИ», 2018. 180 с. - С. 94-98.

${ }^{8}$ Бех В. П., Бех Ю. В. У пошуках нової парадигми освіти // Нова парадигма. Філософія. Політологія. Соціологія / Нац. пед. ун-т імені М. П. Драгоманова. Київ: Вид-во НПУ імені М. П. Драгоманова, 2014. Вип. 123. - С. 19-32.

9 Мельниченко О. П. Основні методи та форми навчання в сучасній вищій школі // Науковий часопис Національного педагогічного університету імені М. П. Драгоманова. Серія 5. Педагогічні науки: реалії та перспективи. Випуск 27. 2011. - С. 176-180.

10 Кліпа Ю. В. Сучасні основи навчання студентів засобами on-line в вищій школі // Нові концепції викладання у світлі інноваційних досягнень європейської дидактики вищої школи : матеріали міжн. наук.-метод. конф., 30-31 жовтня 2017 р. / Укл. С. М. Іваненко та ін. Київ: Вид-во НПУ імені М. П. Драгоманова, 2017. - С. 260-262.

${ }_{11}$ Булда А. А. Електронний підручник в системі сучасних засобів навчання // Науковий часопис Національного педагогічного університету імені М. П. Драгоманова. Серія 22. Політичні науки та методика викладання соціально-політичних дисциплін : зб. наук. праць. Київ: Вид-во НПУ імені М. П. Драгоманова, 2009. Випуск 1. - С. 18-21.

12 Горбунова Людмила, Зглінська Наталія, Пролеєв Сергій та ін. Трансгуманітарність як чинник розвитку сучасної науки і освіти // Філософія освіти: наук. часопис. 2011. № 1-2. / Ін-т вищої освіти АПН України, Нац. пед. ун-т імені М. П. Драгоманова, Укр. академія політичних наук. Київ: Вид-во НПУ імені М.П. Драгоманова, 2011. - С. 97-141.

13 Червона Л. М. Принцип модернізації вітчизняної вищої освіти: академізм vs прагматизм // URL: journals.uran.ua/index.php/2312-1947/article/.../25971. 
standards ${ }^{14}$. Problems of the formation of the student's personality ${ }^{15}$, its value $^{16}$ and ideological ${ }^{17}$ preferences are actively discussed. Instead, questions of the methods of teaching humanities are covered mainly from the perspective of: a) the theoretical and methodological potential of different paradigms of scientific knowledge - of the actionalist intellectual tradition $^{18}$, polyparadigmal principles ${ }^{19}$, synergetics ${ }^{20}$; b) trends ${ }^{21}$ and strategies $^{22}$ for the transformation of Ukrainian education; c) organic combination of traditional and advanced learning technologies ${ }^{23}$; d) step by step nature of the formation of knowledge, skills and abilities ${ }^{24}$; e) intercurricular and interpersonal relations ${ }^{25}$; e) the quality of the educational process ${ }^{26}$, etc. The importance of taking into account by

14 Тараненко Г. Г. Євроінтеграційні перспективи України на сучасному етапі // Науковий часопис Національного педагогічного університету імені М. П. Драгоманова. Серія 22. Політичні науки та методика викладання соціально-політичних дисциплін: зб. наук. праць. Випуск 21. Київ: Вид-во НПУ імені М. П. Драгоманова, 2017. - С. 95-100.

${ }^{15}$ Скотна Надія. Філософська проблема особистості в цивілізаційному вимірі // Молодь і ринок. Дрогобич : 2015. № 3 (122). - С. 6-14.

16 Морозов В. В. Фундаментальні цінності як засада організації освіти в європейському просторі // Науковий часопис Національного педагогічного університету імені М. П. Драгоманова. Серія 7: Релігієзнавство. Культурологія. Філософія / ред. рада: В. П. Андрущенко (голова). Вип. 29 (41). Київ: Вид-во НПУ імені М. П. Драгоманова, 2013. - С. 263-272.

17 Литвиненко Т. С. Філософія виховання у трансформаційному освітньому просторі // Науковий часопис Національного педагогічного університету імені М. П. Драгоманова. Серія 7: Релігієзнавство. Культурологія. Філософія / ред. рада: В. П. Андрущенко (голова). Вип. 37 (50). Київ: Вид-во НПУ імені М. П. Драгоманова, 2017. - С. $76-84$.

${ }^{18}$ Гавриленко І. М., Мельник П. В., Недюха М. П. Соціальний розвиток : навчальний посібник. Київ: Академія ДПС України, 2001. С 128-169, 424-468.

19 Терепищий С. О. Філософська парадигма сучасних освітніх ландшафтів : автореферат дис. ... докт. філос. наук : 09.00.10 / М-во освіти і науки України, Нац. пед. ун-т ім. М. П. Драгоманова. Київ, 2016. 34 с.

${ }^{20}$ Синергетика в образовании : возможности методологии (круглый стол в редакции журнала “Філософія освіти” / Філософія освіти. Philosophy of Education: науковий журнал. 2006. № 3(5) // Ін-т вищої освіти НАПН України, Нац. пед. ун-т імені М. П. Драгоманова, 2006. - С. 54-91.

${ }^{21}$ Регейло I. Ю. Тенденції підготовки наукових і науково-педагогічних кадрів вищої кваліфікації в Україні у XX - на початку XXI століття : автореферат дис. ... докт. пед. наук : 13.00 .04 / М-во освіти і науки України, Нац. пед. ун-т імені М. П. Драгоманова. Київ: 2015. 39 с.

22 Чижова О. М. Стратегія трансформації української освіти в контексті розуміння прагматизму // Науковий часопис Національного педагогічного університету імені М. П. Драгоманова. Серія 22: Політичні науки та методика викладання соціально-політичних дисциплін : зб. наук. праць. Випуск 15. Київ: Вид-во НПУ імені М. П. Драгоманова, 2014. - С. 190 -195.

23 Без'язичний Б. І., Журід С. М., Худякова В. Б., Шаленко В. В. Технологічний підхід до освітнього процесу у ВНЗ // Науковий часопис Національного педагогічного університету імені М. П. Драгоманова. Серія 15. Випуск 5 (87). Київ: Вид-во НПУ імені М.П. Драгоманова, 2017. С. 9-12.

${ }^{24}$ Концептуальні засади розвитку педагогічної освіти в Україні та її інтеграції в європейський освітній простір // URL: www.mon.gov.ua/images/ education.

${ }^{25}$ Клепко С. Ф. Автономія університету і міждисциплінарна інтеграція // Магістратура: історія становлення, перспективи розвитку: матеріали регіональної наук.- практ. конф., 21 квітня 2004 р. / Полтавський державний педагогічний університет імені В. Г. Короленка, Полтавський обласний інститут післядипломної педагогічної освіти імені М. В. Остроградського. Полтава: АСMI, 2004. C. 40-44.

${ }^{26}$ Кремень В. Г. Проблеми якості української освіти в контексті сучасних цивілізаційних змін // Європейські педагогічні студії / Асоціація ректорів педагогічних університетів Європи; ред. кол. В. П. Андрущенко (голова) [та ін.]. Вип. 5-6. Київ: Вид-во НПУ імені М. П. Драгоманова, 2015. C. $12-21$. 
the methods of teaching humanitarian disciplines the possibilities of institutional counteraction to corruption in Ukraine ${ }^{27}$, Ukrainian-Russian relations in the context of the war of identities ${ }^{28}$, the challenges and threats of globalization ${ }^{29}$, its impact on the national cultural identity ${ }^{30}$ and the system of education in general ${ }^{31}$ is also emphasized. Participants of the educational process expressed appreciation to workshops in various areas of legal knowledge, in particular international law with regard to the study of the European experience in harmonizing interstate relations, strengthening the status of supranational institutions, securing the rule of law, and creating a new world order ${ }^{32}$. Numerous works of Ukrainian and foreign scholars cover foreign educational experience ${ }^{33}$, the theory and practice of organizing and securing the college educational process ${ }^{34}$ including criteria, standards and methods for assessing teachers' teaching competence $^{35}$, provision of educational services ${ }^{36}$, etc.

However, despite the obvious progress in many areas of the implementation of the educational process in higher education, the scientific and methodological substantiation of the structure of courses in humanities, in particular sociology, political science, and legal science,

${ }^{27}$ Подоляка С. А. Теоретико-практичні основи адміністративно-правового забезпечення протидії корупції в органах прокуратури України : монографія. Київ: «Людмила», 2018. 440 с.

28 Перепелиця Г. М. Україна - Росія: війна в умовах співіснування. Київ: Видавничий дім «Стилос», 2015. 880 с.

29 Горбунова Людмила. Транскультурна освітня стратегія в контексті викликів глобалізації // Філософія освіти. Philosophy of Education : науковий журнал. 2014. № 1 (14) / Ін-т вищої освіти НАПН України, Нац. пед. ун-т імені М. П. Драгоманова, 2014. С. 158-198.

30 Шевель Н. О. Формування української національної ідентичності в умовах глобалізації освіти // Науковий часопис НПУ імені М. П. Драгоманова. Серія 22. Політичні науки та методика викладання соціально-політичних дисциплін : [збірник наукових праць]. Київ: Видавництво НПУ імені М. П. Драгоманова, 2014. Спецвипуск : Політика і духовність в умовах глобальних викликів : матеріали Міжнар. наук.-практ. конференції, 2-3 квітня 2014 р. - С. 338-342.

${ }^{31}$ Горбунова Людмила. Транскультурна компетентність: освітній шлях до глобальної культури миру // Філософія освіти. Philosophy of Education : науковий журнал. 2014. № 2 (15) / Ін-т вищої освіти НАПН України, Нац. пед. ун-т імені М.П. Драгоманова, 2014. - С. 141-167.

32 Тимченко Л. А., Тимченко Л. Д. Международное право : практикум. Ирпень: Академия ГНС Украины, 2002. 290 с.

33 Штобрин Славомір. Становище філософії освіти в Польщі в кінці XX - на початку XXI століття // Філософія освіти. Philosophy of Education : науковий журнал. 2015. № 1 (16) / Ін-т вищої освіти НАПН України, Нац. пед. ун-т імені М.П. Драгоманова, 2015. - С. 140 -156.

${ }^{34}$ Banks J. A. Cultural Diversity and Education: Foundations, Curriculum and Teaching . - 2014. (6th ed.). Boston: Allyn \& Bacon. 384 pp.

${ }^{35}$ Кляп М. І. Підвищення педагогічної майстерності викладача ВНЗ у контексті інтернаціоналізації вищої школи України // Науковий часопис Національного педагогічного університету імені М. П. Драгоманова. Серія 16 : збірник наукових праць. Вип. 25 (35). Київ: Вид-во НПУ імені М. П. Драгоманова, 2015. - С. 47-52.

${ }^{36}$ Біляєва I. I. Медіа-освіта як ціннісно-культурний компонент трансформації сучасного суспільства // Науковий часопис НПУ імені М. П. Драгоманова. Серія 22. Політичні науки та методика викладання соціально-політичних дисциплін : [збірник наукових праць]. Київ: Видавництво НПУ імені М. П. Драгоманова, 2014. Спецвипуск : Політика і духовність в умовах глобальних викликів : матеріали Міжнар. наук.-практ. конференції, 2-3 квітня 2014 р. - С. 280-288. 
has not yet been proposed. Although as early as at the end of the last century, the importance of solving educational and methodological problems associated with the threats of the fragmentation of scientific knowledge and lack of unity of its elements was rightly emphasized; this fragmentation is evidenced, in particular, by curricula and manuals, where a presentation of special sociological theories (branch sociologies), but not the general theory is often given ${ }^{37}$.

In scientific and methodical literature, the main focus is usually on the development of specific recommendations, tools, techniques, forms of education and training, generalization of teaching experience based on the need to reform the content of education, and there is lack of coverage of problems of the relationship of methodology and methods, of the determining role of the former in relation to the latter, of the problem of "what to teach?" students at lectures and practical classes, during their independent work, etc. Undoubtedly, the development of private methodological issues (the methods for lecturing, conducting seminars, tests, examinations, the technologization and computerization of teaching, the introduction of continuous, distance, on-line education, etc.) is an important and necessary thing. However, the development of problems of subject comprehension of the content of a discipline requires, at least, the conduct of general theoretical, interdisciplinary research with regard to, in particular, the content filling of the educational process in higher education, the definition of its theoretical and methodological foundations, the general "strategy" of training and its components.

\section{The methods of teaching humanities as a didactically redesigned system of scientific knowledge}

It is well-known that the subject of a science is the laws of the development of a particular sphere, an aspect of social life, the level of their comprehension and turning into corresponding theories, doctrines, etc. For example, sociology, as claimed by Pitirim Sorokin, is "a science that studies the lives and activities of people living in a society of ones of their kind and the results of such joint activities" ${ }^{38}$.

An academic discipline reflects the same subject as the science, but indirectly: through the content and level of development of the actual science. The higher a science is developed, the more comprehensively

\footnotetext{
37 Якуба О. О. Соціологія. Харків: «Фоліо», 1996. - С. 9.

${ }^{38}$ Сорокин П. А. Общедоступный учебник социологии. Статьи разных лет / Ин-т социологии. Москва: Наука, 1994. С. 8.
} 
and thoroughly it reflects the subject of its research and, accordingly, the more fully and deeply its essence can be clarified, laid out in curricula, textbooks and manuals, brought to the consciousness of students through the methods of its teaching. Of course, with certain reservations, because a subject matter cannot comprehend all the wealth of the content of the science; it involves only the most significant, generally accepted, established propositions. At the same time, in its problems, it is broader than the science and includes in its structure a number of topics, sections that are not directly related to its subject, its logic, but the study of which is necessary from the training and educational point of view. Into such topics, let us say, in the course of sociology, we can put proto-sociology, the history of sociological thought as well as the definition of the place of the subject matter in the system of professional training of students, ensuring phased nature, interdisciplinary and intercourse ties, etc. Apart from content and structural differences, science and academic discipline also differ in the form of their existence: training courses as a system of knowledge are created through the scientific and methodological processing of the content of a science so that students can comprehend it. One cannot ignore the influence of the laws of pedagogy, the principles of didactics, etc, either. One can consider attributive a certain lag of an academic discipline behind the science in terms of content comprehension of the problems of its subject. Obviously, this requires time, intellectual, personnel and organizational resources, training buildings and the corresponding infrastructure as well as teaching and methodological support (preparation of textbooks, manuals, course programs, etc).

A science and an educational discipline also differ in "departmental" belonging, which determines their different structure, component composition. Whereas the structure of a course belongs to the subject matter, is directly related to the process of learning, the development and education of students, the structure of the science reflects the process of differentiation of knowledge within this particular science, within which there are relatively independent branches of knowledge. In addition, a subject matter should reflect the interdisciplinary connections; take into account the sequence, the place of one or another discipline in the system of training a future specialist, the specifics of the institution of higher education, the department, the specialty in their subordination to the current state of science and the planetary tendencies of its development. Accordingly, it can be argued that an academic discipline in its essence and purpose is a didactically sound system of knowledge in accordance 
with the content of the multicultural model of education ${ }^{39}$, its principles ${ }^{40}$, tasks $^{41}$, goals and objectives ${ }^{42}$.

In addition to optimizing the educational process on the basis of the achievements of modern science, the above-mentioned educational paradigm ${ }^{43}$ involves a person-centered approach, critical thinking, acquiring the appropriate competence, etc., that is, it should be oriented toward the capabilities and needs of future professionals in accordance with the multinational and multicultural environment of their professional activities. And this means that the modern educational paradigm must be open, non-linear, capable of self-organization and self-movement, involve the responsibility of the choice of a teacher in at least two of its main meanings: a) the use of the possibilities of science in its classical, nonclassical and post-non-classical dimensions as a means, resource and potential of socio-cultural changes; b) the construction of an educational subject as an invariant of science, the definition of its structure, the sequence of laying out the content of training in accordance with the specifics of the institution of education, the level of preparation of the students. This is on the one hand. On the other hand, a subject matter should serve as the main means of forming the tolerant principles of their worldview and world comprehension, of forming their professional qualities and personal virtues. From this, it is obvious that the student cannot stand aside from the scenarios of the formation of his own professional and social environment of being and, accordingly, he should be regarded as the object and subject of the educational process at the same time.

\section{Definition of the subject of the methods of teaching humanitarian disciplines as a search research attitude}

In the scientific literature, various search models of the process of substantiation, definition of the subject of the methods of teaching humanitarian disciplines in higher education are offered. Thus, dominant are ideas according to which: 1) the clarification of the essence of the

\footnotetext{
39 Banks J. A. Multicultural Education: Characteristics and Goals / J.A. Banks // Multicultural Education: Issues and Perspectives. Wileys \& Sons, 2003. - P. 3-31.

40 Каньковський Ігор. Принципи професійного навчання фахівців у сучасній вищій школі // Молодь і ринок. Дрогобич : 2015. № 12 (131). С. 15-22.

${ }^{41}$ Jefferson N. Migrant Report Office - Multicultural Education, US Dpt of Education, April, 2002. P. 16-24.

${ }^{42}$ Горак Оксана. Філософія гуманізму. Становлення та розвиток гуманістичної парадигми освіти // Молодь і ринок. Дрогобич, 2015. № 11 (130). С. 147-150.

43 Banks J. A. Multicultural Education: Characteristics and Goals / J.A. Banks // Multicultural Education: Issues and Perspectives. Wileys \& Sons, 2003. - P. 3-31.
} 
subject of the methods of teaching should be carried out through disclosure of the particularities of teaching, which should be determined by the specifics of the subject of a science, its theoretical and methodological potential ${ }^{44}$; 2) the subject of the methods of teaching should be conditioned not by the content of the relevant science, but by the requirements of didactics ${ }^{45}$; 3 ) the methods of teaching humanities represent the science of managing the learning process, which allows its subject to be regarded as a branch of the philosophy of education, in particular, in the cases of information and technological forecasting and management of the development of education in general, the definition of areas for its reforming, the development of state standards of education, the understanding of the ideal of education, the ideal of a harmoniously developed personality ${ }^{46}$; 4 ) the methods of teaching should be considered as a form of comprehension of the content of the science being studied, in accordance with the conditions of life in multicultural society, the prospects for its modernization ${ }^{47}$; 5 ) the subject of the methods of teaching humanities should be determined on the basis of a number of conditions: a) the cognition and use of the laws of pedagogy and didactics; b) the development and application of methods, organizational forms, means, techniques, technologies, etc, which ensure teaching humanities as the basis of world outlook and methodology of knowledge, the formation of a multicultural person; c) the need for humanization of education, which is associated with both objective and subjective reasons, the main among which being the transition of the world community to a new social dimension, which is based on a professionally trained personality in the unity of his national and universal values, humanistic orientations, who, while preserving his own dignity, cultural identity has to adapt to living conditions in the multicultural space ${ }^{48}$.

44 Бех В. П. Философская рефлексия предмета политологии // Вопросы политологии. 2016. № 2 (22). С. 7-16.

45 Лакомчак Зоряна. Дидактичний потенціал сучасної інтернет-дидактики // Молодь і ринок. Дрогобич : 2015. № 8 (127). С. 121-124.

${ }^{46}$ Васиньова Н.С. Розвиток теорії управління вищими навчальними закладами в Україні (остання чверть XX - початок XXI століття). Дисертація на здобуття наук. ступ. канд. пед. наук за спеціальністю 13.00.06 / М-во освіти і науки України, Луганський національний університет імені Тараса Шевченка. Старобільськ : 2019. - 294 с.

${ }^{47}$ Bakhov I. S. Historical dimension to the formation of multicultural education of Canada. Pedagogika. 2015. Vol. 117, Issue 1. P. 7-15.

${ }^{48}$ Недюха М. П. Критика як поняття класичної науки та соціальний феномен громадянського суспільства: потенціал конституційного та міжнародного права // Критичне мислення у вільному суспільстві: теоретико-методологічний, конституційно- та міжнародно-правовий потенціал: Матеріали міжнародної науково-практичної конференції, м. Київ, 17 квітня 2019 р. Київ: Таврійський національний університет імені В. І. Вернадського, 2019. 156 с. 
The last point of view (from the aforementioned ones) deserves, in our opinion, special attention, since the proposed approach to the definition of the subject of the methods of teaching humanitarian disciplines gives the opportunity to rely on all the wealth of the content of the discipline being studied, to build the educational process in accordance with the general civilizational tendencies of socio-cultural changes, the ideals of democracy. The $21^{\text {st }}$ century should be the era of sovereign states with their multicultural and ecological and natural environment, with their spiritual identities, national interests and aspirations. Thus, the humanization of education works for the future and man in it as the creator of the conditions of his everyday life, forms, according to the well-known expression of Polish sociologist Piotr Sztompka, "civilization competence" as the ability to find satisfactory answers to the challenges of the globalized world, to form an atmosphere of tolerance and trust in society, the basis of which is represented by human dignity.

The advantages of the above approach also include the emphasized expediency with regard to the definition of the subject of the methods of teaching humanitarian disciplines, the use of the laws of pedagogy and didactics, effective forms, means, methods and technologies of learning, which are conditioned by the established paradigms of scientific knowledge, by worldview and value vision of the world based on understanding the limitations of purely rational forms of cognition, on the priority of personality oriented education and on the formation of a holistic person as a natural, social and cosmic creature.

The urgent tasks facing the methods of teaching humanities in higher education in accordance with the main propositions of the multicultural model of education are associated with the need for students to master the methodology and specific methods of dialogue, scientific polemics, ability to critically analyze social reality, to find satisfactory answers to the challenges of the present, in particular, the threat of a break-up of the established world order, international terrorism, hybrid wars, etc. Formation of professional competence, professional formation of student youth is inseparable from the creative development of the potential of scientific criticism as a theoreticalcognitive and dialogue-polemical construct of scientific thinking, and hence an integral part of the content of education, methodological and innovativetechnological potential of higher education ${ }^{49}$.

\footnotetext{
49 Недюха М. П. Критика як поняття класичної науки та соціальний феномен громадянського суспільства: потенціал конституційного та міжнародного права // Критичне мислення у вільному суспільстві: теоретико-методологічний, конституційно- та міжнародно-правовий потенціал: Матеріали міжнародної науково-практичної конференції, м. Київ, 17 квітня 2019 р. Київ: Таврійський національний університет імені В. І. Вернадського, 2019. С. 14-20.
} 
It is obvious that the aforementioned activity of subject definition of the essence of the methods of teaching humanities should be based on the paradigmatic conditionality of scientific knowledge in its classical, nonclassical and post-non-classical dimensions, the awareness of the direct connection of knowledge with the relations that form between people in the process of their daily life and the nature, method and features of their legal and regulatory and ethical and moral regulation. It is clear that the specified content and functional orientation of the content of education, the dynamics of the process of training and education should be deployed and subordinated to the main goal - the formation of a civilization (European) identity as a unity of the universal, continental, national and regional. Individualization as, according to Sygmunt Bauman, "the establishment of the autonomy of an individual de jure" ${ }^{50}$, can be considered another embodiment of civilization identity. Scientific, educational and methodological and pedagogical and didactic combination of these requirements in the course of teaching humanitarian disciplines allows to carry out, in accordance with the basic foundations of multicultural education, the didactically correct transformation of a science into the corresponding educational discipline, to ensure the proper sequence, stepping, systemacity and effectiveness of the preparation of the future specialist, obtaining him qualification competence for life in a multicultural environment.

For example, teaching legal disciplines in accordance with the requirements of the principle of unity of the universal, continental, national and regional contributes, as shown by the experience of Vernadsky Taurida National University, to the humanization of understanding, interpretation of national legislation with several meanings: a) the humanization of legislation as the correspondence of its norms, legal and regulatory acts to universal values and moral and ethical principles; b) the humanization of legislation as its harmonization - the process of approximation and adaptation to the legal norms of the member states of the European Union $^{51}$; c) humanization of the legislation as the implementation of the norms of international law in the domestic legislative field; d) humanization of legislation as the interdependent process of interaction between different legal systems with regard to,

\footnotetext{
${ }^{50}$ Бауман Зигмунт. Индивидуализированное общество / Пер. с англ. под ред. В. Л. Иноземцева. Москва: Логос, 2002. С. 81.

51 Шемшученко Ю. С. Теоретические проблемы гармонизации законодательства Украины с европейским правом / Проблемы гармонизации законодательства Украины и стран Европы / Под общ. ред. Е. Б. Кубко, В. В. Цветкова. Киев: Юринком Интер, 2003. С. 35-40.
} 
primarily, the technical and legal improvement of the activities of legislative institutes ${ }^{52}$; e) humanization of legislation as the decriminalization of economic crimes, which stipulates the need to clarify the organizational and legal preconditions for the introduction of probation as a means of humanization of criminal justice, the formation, in particular, of the probation service - a system of supervision, social, educational and preventive measures of the approximation to the norms of European justice by replacing criminal liability with administrative one for certain types of crimes in economic and business activities. At least, in European countries, the probation service, as is known, significantly facilitates the work of law enforcement agencies, the judicial system, ensures the coordination of the interaction of state institutions, local governments, non-governmental organizations, individual citizens (volunteers) in the process of enforcing sentences alternative to deprivation of liberty ${ }^{53}$.

Interesting and largely ignored methods of teaching humanities at higher school are represented by the European experience with regard to ensuring the internal security of the state through means of probation.

At the same time, in the process of teaching legal disciplines, it should be emphasized that, the first of the aforementioned meanings of the term corresponds to the content of the term "humanization of legislation" best of all, while other definitions reflect, rather, the content of the legal categories "approximation" and "harmonization", although with varying degrees of completeness . It is advisable, of course, to rely on the norms of international law as a generally accepted standard of regulation of interstate relations. At the same time, it is hardly possible to agree with the assertions that the integration processes in the field of law are deployed as: a) the technical and legal harmonization of legislation (through methods of creating specific legal mechanisms of the interaction of legal systems); and b) direct approximation of Ukraine to European principles, ideals of democracy, the protection of human and civil rights ${ }^{54}$.

Philosophy-centrism with its human and nature correspondence, techno-informational and technological and innovation support as a sign of the unity of science and education, the continuity of mastering and

\footnotetext{
52 Кубко Е. Б. Совершенствование законодательства Украины и проблемы его гармонизации с законодательством зарубежных стран / Проблемы гармонизации законодательства Украины и стран Европы / Под общ. ред. Е. Б. Кубко, В. В. Цветкова. Киев: Юринком Интер, 2003. С. 61-78.

53 Кулик О. Г. Пробація // Юридична енциклопедія: В 6 т. / Редкол.: Ю. С. Шемшученко (голова редкол.) та ін. Т. 5. Київ: «Укр. енцикл.», 2003. С. 146-147.

${ }^{54}$ Политико-правовые и конституционно-правовые аспекты гармонизации законодательства Украины и стран Европы / Проблемы гармонизации законодательства Украины и стран Европы / Под общ. ред. Е. Б. Кубко, В. В. Цветкова. Киев: Юринком Интер, 2003. С. 97.
} 
reproduction of knowledge, its enrichment and development, harmony of education of a person and his humanistic self-realization is the theoretical and methodological basis of the methods of teaching humanities, a peculiar worldview core of didactic transformation of the content of science.

So what kind of value system can claim to be the universal, all-planet educational ideology or, say, the European one as its subsystem? First of all, it may obviously be represented by philosophical-ideological principles aimed at forming the essence of man as a representative of earthly civilization, its culture, the achievements of the humanity, etc, which (the principles) are in harmony with a separate personality, society, nature and space. And this means that the ideological foundations of the contemporary worldview of multicultural education should be complemented by anthropocosmic principles of conformity to nature, coherence of social development with evolutionary, elemental in nature, processes occurring in nature and space. That is, using the terminology of V. I. Vernadsky, our contemporary needs a noosphere type of worldview $^{55}$, which is based on the understanding of man as a natural, social and cosmic being, the rights and freedoms of man and citizen as natural and inalienable. Modern world humanistics proceeds from the fact that just a person, his rights and duties, demands and needs should be at the center of the attention of the state and society, and all social space is humanized, full of humanistic meaning, according to which a person, his life is the highest value, which, accordingly, involves the need to create appropriate conditions as the basic and determinant at the same time for full life, for self-realization of an individual. It seems that the aforementioned, in Ukrainian realities, involves, first of all, the possibilities of self-organization and self-governance, of decentralization of power in accordance with the constitutional requirements of the rule of law, of the establishment of united territorial communities as subjects of sovereignty of the people. The implementation of these requirements by means of the educational process is, at the same time, the answer to the question under what conditions welfare and abundance start belonging to the people, form its creative, intellectual potential, the ability to conduct social changes and implement promising scenarios of civilization development ${ }^{56}$. In this context, the humanization of education must give the student knowledge about society and the person in it, nature and

${ }^{55}$ Вернадский В. И. Начало и вечность жизни / Сост., вступ. ст., коммент. М. С. Бастраковой, И. И. Мочалова, В. С. Неаполитанской. Москва: Сов. Россия, 1989. 704 с.

${ }^{56}$ Гавриленко І. М., Мельник П. В., Недюха М. П. Соціальний розвиток : навчальний посібник. Київ: Академія ДПС України, 2001. С. 424-484. 
space, the place and purpose of the individual, allows to instill in young people high humanistic qualities - humanity, dignity, critical thinking, culture of communication, to establish civilized cohabitation as normalcy. The humanization of education "works" for the future and a person in it as the creator of the conditions of his life, his eternity and uniqueness in nature, society and space. Accordingly, in its essence, the humanization of education is directed at the transformation of educational activity - in terms of content, forms and technologies of learning - in the continuous process of ensuring the integrity of the formation of the personality of a future specialist in the unity of the natural, social and cosmic components, the affirmation of the subjectivity of human existence.

The aforementioned orientation of the methods of teaching humanitarian disciplines in higher education envisages, in particular: a) the realization of human and civil rights and freedoms for qualitative educational services; b) ensuring the unity of science and education in the educational process; c) subordinating the educational process to the needs of providing dynamic social changes, of innovation and technological development by forming a unified knowledge production environment and implementing its results; d) participation in international co-operation in the field of education and science, including with regard to the legal and regulatory substantiation of the process of entering the world and European educational and scientific space.

The purpose of education with regard to finding answers to the challenges of sovereign development lies in its focus on the formation of an innovation and investment environment for social changes, the production of scientific and technological developments and inventions and their introduction through the unity of education, science and production. In this triune interaction, the decisive role belongs, of course, to science as "a planetary phenomenon" ${ }^{57}$, to the sphere of professional activity, to social institute and, on many grounds, to "geological force" ${ }^{58}$. It is no accident that V. I. Vernadsky, considering the humanistic nature of science, its decisive role in solving the problems of human life, considered science as a geological and historical power at the same time, able to change the life of both the biosphere and humanity ${ }^{59}$. Accordingly, science should be seen as a means, resource and potential of development, the basis of which is represented, of course, by the abilities of the human

${ }^{57}$ Вернадский В. И. Начало и вечность жизни / Сост., вступ. ст., коммент. М. С. Бастраковой, И. И. Мочалова, В. С. Неаполитанской. Москва: Сов. Россия, 1989. С. 131-155.

${ }^{58}$ Там же. С. $133,135$.

${ }^{59}$ Там же. С. 131. 
mind. The power of man, as well as his weakness, his self-sufficiency and limitation, self-organization and chaotic social conditions cannot be considered beyond his mind, which subordinates human actions to the goals defined by classical science (description, awareness, solution and prediction), non-classical one (the positioning of subject of social action) and post-non-classical one (the construction of social space).

The task of the higher school, its social purpose is seen in the theoretical and methodological and methodological and technological revision, adaptation of scientific knowledge in accordance with the goals of the educational process, in building the latter in accordance with the requirements of the defining principles of didactics - the availability of knowledge, its continuity, consistency and ensuring the system integrity of the process of the assimilation of scientific knowledge, etc. The problem is that this link between science and education is not unambiguous, linear, given the ambivalence of science, which implies the need for humanization of scientific knowledge by, in particular, mitigating the effect of threatening tendencies, one of which is, as is known, the pragmatization of science, the consequence of which is not only obtaining benefits, but also suffering significant losses, in particular, environmental ones. The safe environment of human existence also involves taking into account possible negative social consequences of the application of the results of certain scientific and technological achievements in practice; the notorious technogenic accident at the Chernobyl Nuclear Power Plant can serve as an example.

\section{CONCLUSIONS}

Education should provide satisfactory answers to the challenges of sovereign development, of the globalization era by means of didacticmethodological transformation of achievements of world and national science, its humanization: the conceptual foundations of state educational policy should ensure the unity of science and education by adapting the achievements of the former to the tasks and objectives of the educational process, ensuring it efficiency, availability, continuity, consistency, and systemacity. Accordingly, the methods of teaching should contribute to the disclosure of the content of the discipline as a system of scientific knowledge in its subordination to the process of finding the truth, positioning and constructing the social space in accordance with the priorities of the process of social change, the cosmization of science, the understanding of the modern historical age as contradictory and 
critical at the same time with regard to the formation of the noosphere type of thinking and social action. The above, in particular, implies: a) understanding the essence of man as a bio-socio-cosmic being; b) the formation of the noosphere type of thinking and of the corresponding identity of the student - civil, national, political one, etc; c) professional training a future specialist, obtaining by him the necessary qualification competence, his readiness for life in a globalized multicultural environment.

Given the close relationship between methods and methodology, the didactical revision of the content of science, the purpose and task of the study, it can be argued that the methods of teaching humanitarian disciplines in higher education should study the laws of self-movement of the content of the discipline, the forms of organization and of the innovation and technological provision of the educational process in accordance with the requirements of pedagogy and didactics, the content and functional characteristics of the paradigms of scientific knowledge, the priority of human and civil rights and freedoms, the challenges and threats of the globalization era in their subordination to the formation of a noosphere type of thinking.

The above definition of the subject of the methods of teaching humanities, although it reflects the main, essential aspect of the process of training and education, namely its content orientation, consistency and purposefulness, cannot be considered complete, exhaustive, let alone definitive. As it is known, teaching any humanitarian discipline at a higher school is a creative matter, to a certain extent an art that requires not only the consideration of the movement of the content of learning, of organizational forms and technologies for its ensuring, but also the clarification of their relationship with each other with regard to, in particular, the most effective way of communicating the contents of learning to the consciousness of students, the acquisition of knowledge, critical attitude toward it, etc. The above envisages taking into account the specifics of the institution of higher education, the department, the audience, the knowledge already received by the students previously, ascertaining which sections of the course or its individual propositions to lay out in lectures or to make the subject of discussion at seminars, to give to the students for independent study, etc. Therefore, it is quite right to note that the methods of teaching humanities should study the correlation between the laws of motion (self-organization) of the content of the discipline being studied, organizational forms and modern technologies 
of ensuring the educational process, which (correlation) manifests itself in the most effective means of communicating the content of training to the students' consciousness, the formation of a noosphere type of thinking and action. In this case, the methods of teaching humanitarian disciplines in accordance with its above-mentioned subject facilitates the transformation of the educational process into a partner dialogue between the teacher and the student, of course, with the preservation of the status and role functions of each of them.

\section{SUMMARY}

The analysis of the correlation of a science and the academic discipline, of the functional unity of the content, forms and technologies of learning in the conditions of the use in the educational process of the classical, non-classical and post-non-classical paradigms of scientific knowledge allows to substantiate the subject of the methods of teaching humanities in higher education in accordance with the multicultural model of the educational process and the tasks of the formation of a noosphere type of thinking and action. Defining the content of the subject of the methods of teaching humanities at the higher school of Ukraine should facilitate the gradual transition of the educational process from the predominantly multi-ethnic coverage of the content of education to understanding it as a multicultural, intercultural and intergroup environment of interaction between the teacher and the students, forming a culture of tolerance, critical thinking, avoiding manifestations of discrimination, ethnocentrism and assimilation, etc. Professional competence as a decisive feature of the quality of the educational process should involve the unity of the content, goals and methodological and technological support of the educational process. The said implies the expediency of developing the problems of content filling of humanitarian disciplines, defining their place, structure, interdisciplinary connections, and also the normative and legal provision of teaching humanities in accordance with the basic propositions of the multicultural model of education, the formation of a noosphere type of thinking of a future specialist. Accordingly, the subject of the methods of teaching humanities at a higher school, due to the current state of development of science, requires didactic and pedagogical revision of its content by clarifying the effect of the latest trends of exponential growth of scientific knowledge and its use in the educational process, its results and social consequences, in particular: a) understanding the essence of man as a bio-socio-cosmic 
being; b) the content and nature of the cosmization of scientific knowledge, the transformation of science into a phenomenon of a planetary scale that acquires features of a geological force; c) the possibilities of a new synthesis of the natural and human sciences, laws of nature and space, society and man in a globalized multicultural space. It seems that the above will contribute to the crystallization of the subject of the methods of teaching humanitarian disciplines in higher education in its dependence on open potential and meaning benchmarks for the formation of a noosphere type of thinking within the framework of the multicultural model of education.

\section{REFERENCES}

1. Bennett C. I. Comprehensive multicultural education: Theory and practice / C.I. Bennett. Boston: Allyn \& Bacon, 1999. - 345 p.

2. Banks J. A. Multicultural Education: Characteristics and Goals / J. A. Banks // Multicultural Education: Issues and Perspectives. Wileys \& Sons, 2003. - P. 3-31.

3. Hелеп A. T. Теоретические проблемы методики преподавания философии. Киев: «Вища школа», 1973. - 291 с.

4. Мойсеюк Н. Є. Педагогіка : навчальний посібник. Вид. п’яте, доп. і перероб. Київ: ВАТ «Білоцерківська книжкова фабрика», 2007. $656 \mathrm{c}$.

5. Андрущенко Т.В. Ціннісний дискурс цивілізацій: монографія. Київ: Університет «Україна», 2011. - 440 с.

6. Дмитренко М. А. Наука і освіта як невід'ємна складова механізму реалізації стратегій інноваційного розвитку суспільства // Науковий часопис НПУ імені М. П. Драгоманова. Серія 22. Політичні науки та методика викладання соціально-політичних дисциплін. 2009. Випуск 2. - С. 24-33

7. Недюха М. П. Критика як теоретико-пізнавальний та діалоговополемічний конструкт конституційно-правового мислення // II Bceукраїнські правові наукові читання пам'яті доктора юридичних наук, професора, заслуженого юриста України, член-кореспондента Національної академії правових наук України Ніни Романівни Нижник: збірник матеріалів / за заг. ред. А. С. Шевченка. Вінниця: ТОВ «ТВОРИ», 2018. 180 с. - С. 94-98.

8. Бех В. П., Бех Ю. В. У пошуках нової парадигми освіти // Нова парадигма. Філософія. Політологія. Соціологія / Нац. пед. ун-т імені М. П. Драгоманова. Київ: Вид-во НПУ імені М. П. Драгоманова, 2014. Вип. 123. - С. 19-32. 
9. Мельниченко О. П. Основні методи та форми навчання в сучасній вищій школі // Науковий часопис Національного педагоггічного університету імені М. П. Драгоманова. Серія 5. Педагогічні науки: реалії та перспективи. Випуск 27. 2011. - С. 176-180.

10. Кліпа Ю. В. Сучасні основи навчання студентів засобами оnline в вищій школі // Нові концепції викладання у світлі інноваційних досягнень європейської дидактики вищої школи : матеріали міжн. наук.-метод. конф., 30-31 жовтня 2017 р. / Укл. С. М. Іваненко та ін. Київ: Вид-во НПУ імені М.П. Драгоманова, 2017. - С. 260-262.

11. Булда А. А. Електронний підручник в системі сучасних засобів навчання // Науковий часопис Національного педагогічного університету імені М. П. Драгоманова. Серія 22. Політичні науки та методика викладання соціально-політичних дисциплін : зб. наук. праць. Київ: Вид-во НПУ імені М. П. Драгоманова, 2009. Випуск 1. C. $18-21$.

12. Горбунова Людмила, Зглінська Наталія, Пролеєв Сергій та ін. Трансгуманітарність як чинник розвитку сучасної науки і освіти // Філософія освіти: наук. часопис. 2011. № 1-2. / Ін-т вищої освіти АПН України, Нац. пед. ун-т імені М. П. Драгоманова, Укр. академія політичних наук. Київ: Вид-во НПУ імені М.П. Драгоманова, 2011. C. $97-141$.

13. Червона Л. М. Принцип модернізації вітчизняної вищої освіти: академізм vs прагматизм // URL: journals.uran.ua/index.php/ 2312-1947/article/.../25971.

14. Тараненко Г. Г. Свроінтеграційні перспективи України на сучасному етапі // Науковий часопис Національного педагогічного університету імені М. П. Драгоманова. Серія 22. Політичні науки та методика викладання соціально-політичних дисциплін: зб. наук. праць. Випуск 21. Київ: Вид-во НПУ імені М. П. Драгоманова, 2017. C. $95-100$.

15. Скотна Надія. Філософська проблема особистості в цивілізаційному вимірі // Молодь і ринок. Дрогобич : 2015. № 3 (122). C. 6-14.

16. Морозов В. В. Фундаментальні цінності як засада організації освіти в європейському просторі // Науковий часопис Національного педагогічного університету імені М. П. Драгоманова. Серія 7: Релігієзнавство. Культурологія. Філософія / ред. рада: В. П. Андрущенко (голова). Вип. 29 (41). Київ: Вид-во НПУ імені М. П. Драгоманова, 2013. - С. 263-272. 
17. Литвиненко Т. С. Філософія виховання у трансформаційному освітньому просторі // Науковий часопис Національного педагогічного університету імені М. П. Драгоманова. Серія 7: Релігієзнавство. Культурологія. Філософія / ред. рада: В. П. Андрущенко (голова). Вип. 37 (50). Київ: Вид-во НПУ імені М. П. Драгоманова, 2017. - С. 76-84.

18. Гавриленко І. М., Мельник П. В., Недюха М. П. Соціальний розвиток : навчальний посібник. Київ: Академія ДПС України, $2001.484 \mathrm{c}$.

19. Терепищий С. О. Філософська парадигма сучасних освітніх ландшафтів : автореферат дис. ... докт. філос. наук : 09.00.10 / Мво освіти і науки України, Нац. пед. ун-т ім. М. П. Драгоманова. Київ, 2016. 34 с.

20. Синергетика в образовании : возможности методологии (круглый стол в редакции журнала «Філософія освіти» / Філософія освіти. Philosophy of Education: науковий журнал. 2006. № 3(5) // Ін-т вищої освіти НАПН України, Нац. пед. ун-т імені М. П. Драгоманова, 2006. - С. 54-91.

21. Регейло I. Ю. Тенденції підготовки наукових i науковопедагогічних кадрів вищої кваліфікації в Україні у XX - на початку XXI століття : автореферат дис. ... докт. пед. наук : 13.00 .04 / М-во освіти і науки України, Нац. пед. ун-т імені М. П. Драгоманова. Київ: 2015. 39 с.

22. Чижова О. М. Стратегія трансформації української освіти в контексті розуміння прагматизму // Науковий часопис Національного педагогічного університету імені М. П. Драгоманова. Серія 22: Політичні науки та методика викладання соціально-політичних дисциплін : зб. наук. праць. Випуск 15. Київ: Вид-во НПУ імені М. П. Драгоманова, 2014. - С. 190-195.

23. Без’язичний Б. І., Журід С. М., Худякова В. Б., Шаленко В. В. Технологічний підхід до освітнього процесу у ВНЗ // Науковий часопис Національного педагогічного університету імені М. П. Драгоманова. Серія 15. Випуск 5 (87). Київ: Вид-во НПУ імені М. П. Драгоманова, 2017. С. 9-12.

24. Концептуальні засади розвитку педагогічної освіти в Україні та iii інтеграції в європейський освітній простір // URL: www.mon.gov.ua/ images/education.

25. Клепко С. Ф. Автономія університету і міждисциплінарна інтеграція // Магістратура: історія становлення, перспективи розвитку: 
матеріали регіональної наук. - практ. конф., 21 квітня 2004 р. / Полтавський державний педагогічний університет імені В. Г. Короленка, Полтавський обласний інститут післядипломної педагогічної освіти імені М. В. Остроградського. Полтава: АСМI, 2004. C. 40-44.

26. Кремень В.Г. Проблеми якості української освіти в контексті сучасних цивілізаційних змін // Європейські педагогічні студії / Асоціація ректорів педагогічних університетів Європи; ред. кол. В. П. Андрущенко (голова) [та ін.]. Вип. 5-6. Київ: Вид-во НПУ імені М. П. Драгоманова, 2015. - С. 12-21.

27. Подоляка С. А. Теоретико-практичні основи адміністративно-правового забезпечення протидії корупції в органах прокуратури України : монографія. Київ: «Людмила», 2018. 440 с.

28. Перепелиця Г. М. Україна - Росія: війна в умовах співіснування. Київ: Видавничий дім «Стилос», 2015. 880 с.

29. Горбунова Людмила. Транскультурна освітня стратегія в контексті викликів глобалізації // Філософія освіти. Philosophy of Education : науковий журнал. 2014. № 1 (14) / Ін-т вищої освіти НАПН України, Нац. пед. ун-т імені М. П. Драгоманова, 2014. C. $158-198$.

30. Шевель Н.О. Формування української національної ідентичності в умовах глобалізації освіти // Науковий часопис НПУ імені М. П. Драгоманова. Серія 22. Політичні науки та методика викладання соціально-політичних дисциплін : [збірник наукових праць]. Київ: Видавництво НПУ імені М.П. Драгоманова, 2014. Спецвипуск : Політика і духовність в умовах глобальних викликів : матеріали Міжнар. наук.-практ. конференції, 2-3 квітня 2014 р. C. 338-342.

31. Горбунова Людмила. Транскультурна компетентність: освітній шлях до глобальної культури миру // Філософія освіти. Philosophy of Education : науковий журнал. 2014. № 2 (15) / Ін-т вищої освіти НАПН України, Нац. пед. ун-т імені М.П. Драгоманова, 2014. - С. 141-167.

32. Тимченко Л. А., Тимченко Л. Д. Международное право : практикум. Ирпень: Академия ГНС Украины, 2002. 290 с.

33. Штобрин Славомір. Становище філософії освіти в Польщі в кінці XX - на початку XXI століття // Філософія освіти. Philosophy of Education : науковий журнал. 2015. № 1 (16) / Ін-т вищої освіти НАПН України, Нац. пед. ун-т імені М.П. Драгоманова, 2015. C. $140-156$. 
34. Banks J. A. Cultural Diversity and Education: Foundations, Curriculum and Teaching . - 2014. (6 ${ }^{\text {th }}$ ed.). Boston: Allyn \& Bacon. $384 \mathrm{pp}$.

35. Кляп М. І. Підвищення педагогічної майстерності викладача ВН3 у контексті інтернаціоналізації вищої школи України // Науковий часопис Національного педагогічного університету імені М. П. Драгоманова. Серія 16 : збірник наукових праць. Вип. 25 (35). Київ: Вид-во НПУ імені М.П. Драгоманова, 2015. - С. 47-52.

36. Біляєва I. І. Медіа-освіта як ціннісно-культурний компонент трансформації сучасного суспільства // Науковий часопис НПУ імені М. П. Драгоманова. Серія 22. Політичні науки та методика викладання соціально-політичних дисциплін : [збірник наукових праць]. Київ: Видавництво НПУ імені М.П. Драгоманова, 2014. Спецвипуск : Політика і духовність в умовах глобальних викликів : матеріали Міжнар. наук.-практ. конференції, 2-3 квітня 2014 р. C. 280-288.

37. Якуба О. О. Соціологія. Харків: «Фоліо», 1996. 337 с.

38. Сорокин П. А. Общедоступный учебник социологии. Статьи разных лет / Ин-т социологии. Москва: Наука, 1994. 560 с.

39. Каньковський Ігор. Принципи професійного навчання фахівців у сучасній вищій школі // Молодь і ринок. Дрогобич : 2015. №12 (131). C. 15-22.

40. Jefferson N. Migrant Report Office - Multicultural Education, US Dpt of Education, April, 2002. P. 16-24.

41. Горак Оксана. Філософія гуманізму. Становлення та розвиток гуманістичної парадигми освіти // Молодь і ринок. Дрогобич, 2015. № 11 (130). С. 147-150.

42. Бех В. П. Философская рефлексия предмета политологии // Вопросы политологии. 2016. № 2 (22). С. 7-16.

43. Лакомчак Зоряна. Дидактичний потенціал сучасної інтернетдидактики // Молодь і ринок. Дрогобич : 2015. № 8 (127). С. 121-124.

44. Васиньова Н.С. Розвиток теорії управління вищими навчальними закладами в Україні (остання чверть XX - початок XXI століття). Дисертація на здобуття наук. ступ. канд. пед. наук за спеціальністю 13.00.06 / М-во освіти і науки України, Луганський національний університет імені Тараса Шевченка. Старобільськ : 2019. - 294 c.

45. Bakhov I. S. Historical dimension to the formation of multicultural education of Canada. Pedagogika. 2015. Vol. 117, Issue 1. P. 7-15. 
46. Недюха М. П. Критика як поняття класичної науки та соціальний феномен громадянського суспільства: потенціал конституційного та міжнародного права // Критичне мислення у вільному суспільстві: теоретико-методологічний, конституційно- та міжнародно-правовий потенціал: Матеріали міжнародної науково-практичної конференції, м. Київ, 17 квітня 2019 р. Київ: Таврійський національний університет імені В. І. Вернадського, 2019. 156 с.

47. Бауман Зигмунт. Индивидуализированное общество / Пер. с англ. под ред. В. Л. Иноземцева. Москва: Логос, 2002. 390 с.

48. Шемшученко Ю. С. Теоретические проблемы гармонизации законодательства Украины с европейским правом / Проблемы гармонизации законодательства Украины и стран Европы / Под общ. ред. Е. Б. Кубко, В. В. Цветкова. Киев: Юринком Интер, 2003. С. 35-40.

49. Кубко Е. Б. Совершенствование законодательства Украины и проблемы его гармонизации с законодательством зарубежных стран / Проблемы гармонизации законодательства Украины и стран Европы / Под общ. ред. Е. Б. Кубко, В. В. Цветкова. Киев: Юринком Интер, 2003. С. 61-78.

50. Кулик О. Г. Пробація // Юридична енциклопедія: В 6 т. / Редкол.: Ю. С. Шемшученко (голова редкол.) та ін. Т. 5. Київ: «Укр. енцикл.», 2003. 736 с.

51. Политико-правовые и конституционно-правовые аспекты гармонизации законодательства Украины и стран Европы / Проблемы гармонизации законодательства Украины и стран Европы / Под общ. ред. Е. Б. Кубко, В. В. Цветкова. Киев: Юринком Интер, 2003. С. 97.

52. Вернадский В. И. Начало и вечность жизни / Сост., вступ. ст., коммент. М.С. Бастраковой, И. И. Мочалова, В. С. Неаполитанской. Москва: Сов. Россия, 1989. 704 с.

\section{Information about the author:}

Nediukha M. P.

Doctor of Philosophic Sciences, Doctor of Law, Professor, Professor at the Department of Constitutional and International Law of the V. I. Vernadsky Taurida National University 33, Ivan Kudria str., Kyiv, Ukraine nngi@tnu.edu.ua 


\section{PEDAGOGICAL PROJECT DESIGN IN EDUCATIONAL ACTIVITY}

\section{Radomsky I. P.}

\section{INTRODUCTION}

Project activity is a universal means of human development. Adults can use the project activity for self-improvement, improvement of environment and professional development; it can become a generator of creative expression of personality.

Considering the project activity in general, one should mentioned that in addition to a technical project design, we distinguish a social project design aimed at creating social elements of human life activity.

The urgent issue of innovation process implementation in education and adult education is, in particular, implementation of the pedagogical project design. The project design of an educational activity is a vital scientific problem providing implementation of the whole range of research tasks.

The employees of education field are actively being involved in the project activity. It helps to develop imagination, creative work, creativity, promotes a social activity, enriches emotionally through the feeling of ability to change the reality. The efficiency of a pedagogue depends more and more on his or her skills in building up own activity on the scientific basis, planning not only the educational process itself, but also its results, imagining in details future changes, evaluating their anticipated effect.

The employee in the educational field involved in the project activity has the opportunity to implement educational projects as a developer or executor in the institution where he or she works, to design own educational programs, courses or trainings, be involved in network projects.

The pedagogical project design development is connected with explorations of opportunities to increase efficiency of the educational process.

Studying the range of problems of innovation pedagogical system project design, V. Dokuchaeva ${ }^{1}$ has determined a range of contradictions which make the pedagogical project design relevant:

${ }^{1}$ Докучаєва В. В. Проектування інноваційних педагогічних систем: теоретико-методологічний аспект / В. В. Докучаєва // Андрагогічний вісник. - 2014. - № 5. - С. 37-46. 
- Between the social order of educational field for creation of innovation pedagogical systems and non-development of theoreticalmethodological substantiation of this activity;

- Between objective meaning of psychological component of the process of creation of innovation pedagogical systems and its insufficient awareness in pedagogical design practice;

- Between the demand of educational field for thorough equipment of an innovation design activity and non-development of its technological basis;

- Between modern requirements of pedagogical practice to implementation of innovation activity at the system-design level and availability of stable dominants of professional thinking by the subjects governing innovation projects implementation in educational space;

- Between the public needs for functional competence of the subject of innovation pedagogical system project design and lack of theoretically substantiated model of such competence.

In the philosophical aspect, project designing is seen as an element of culture, promoting the development of a person's creative work and imagination, and the project as a result of spiritual transformation activity. "Every action that is not instinctive, not impulsive ... but purposeful, had to be carried out on the basis of the previous project"

\section{Historical Aspects of Pedagogical Project Design in Education}

In the educational field, the project activity as a source of pedagogical activity was formed over a long period. The necessity of introducing research orientation into the pedagogical process was noted by the founder of pedagogy Ya. J. Komensky. He wrote: "People have to be taught mainly to receive knowledge not from books, but by observing the heaven and the earth, oaks, beeches, that is, that they have to study and cognize the objects themselves and not to remember only others' observations and explanation"3.

J. J. Rousseau advised to put to a child accessible to his or her understanding questions and give the child an opportunity to independently solve them. "Let the child finds out not because you have said to him or her, but because he or her understood themselves; let him or her not learn science, but make it up ${ }^{4}$.

\footnotetext{
${ }^{2}$ Каган М. С. Философия культуры. - СПб., 1996. - С. 240.

${ }^{3}$ Коменский Я.А. Великая дидактика / Пер. А. Щекинского. - М., 1893. С. 138.

${ }^{4}$ Руссо Ж.Ж. Эмиль, или О воспитании. - М., 1996. - С. 211.
} 
In the 19th century, heuristic methods aimed at the development of autonomy in cognitive activity were being developed actively in the pedagogy. A. Diesterweg noticed features of heuristic methods, namely: forcing the student to independency; research of phenomena; search for truth through personal reflection, research; aspiration of the student to receive answers to the questions that naturally arise in him or her; inductive way of developing a problem ${ }^{5}$. J. Armstrong as another supporter of the heuristic method noted that the heuristic method puts a student in the position of a researcher and allows discovering scientific facts instead of only hearing about them ${ }^{6}$.

At the beginning of the $20^{\text {th }}$ century J. Dewey, K. Popper, H. Simon, W. H. Kilpatrick, E. Collings and others made a significant contribution to the development of project activities in the educational field.

The project method as a pedagogical technology and a form of educational work spread in the first half of the $20^{\text {th }}$ century. It combined heuristic, research, experimental, and scientific components. The founder of the project method is considered to be the American philosopher and teacher J. Dewey. The scientist considered educational mission in the fact that education had to develop the student's ability to solve his or her vital needs of life "here and now" rather than merely give knowledge necessary in the future.

J. Dewey considered school as a place where a child is taught to live in the surrounding world, to work together with peers and adults, thereby acquiring the necessary knowledge. At the same time learning should be based on the students' own experience and focus on their interests and needs. The main way of learning is to study the surrounding environment in the project form. Any action performed individually, in a group, with the participation and with the support of a teacher or other people, a child must plan, execute, analyze and evaluate independently ${ }^{7}$.

Russian researcher of the history of education A. I. Piskunov describes the project method (J. Dewey, W. Kilpatrick) in the following way: "In the process of learning children plan (design) the implementation of a specific practical task, including learning there. Despite the fact that the supervision remained with a teacher, this method was based on the existing experience of the child, his or her own way of searching, overcoming difficulties. W. Kilpatrick believed that only under such system of learning education can turn into a continuous transformation of

\footnotetext{
${ }^{5}$ Дистерверг А. Руководство для немецких учителей. - Изд. Т. Тихомирова, 1913.

6 Ягодовский К.П. Исследовательский метод в школьном обучении. - М.; Л., 1929. - С. 64.

${ }^{7}$ Dewey J. Experience and Education. - N.-Y., 1938.
} 
the child's life and raise him or her to a higher level, and the school will prepare students for the conditions of a dynamically changing situation in society and to the facing with unknown problems in the future. Later on, this method as well as other ideas of John Dewey was used in many countries of the world"8.

Another researcher of the history of pedagogy O.N. Dzhurinsky considering the implementation of the project method in pedagogy of US schools in 20-30s of the 20th century by W. Kilpatrick, the follower of J. Dewey, stated the following: "The students designed themselves what they had to do. Particular attention was paid to the type of activity through which knowledge was obtained. Materials for learning were taken from everyday life. The students chose themselves what had to be the content of the educational work; the teacher only provided them with assistance in the performance of something they intended to do $^{9}$.

W. Kilpatrick defined the project activity as "a reasonable activity carried out with all one's heart, which manifests itself in certain social conditions, which is chosen for the typical feature of school life" 10 . The scientist outlined the following components of his pedagogical system: the learning material, which stems from the nature and interests of students; reasonable activity; learning as a continuous transformation of life and the transition to its higher levels. The aim of the study was to master methods of problem solving, search, research by students. In his scientific works, Kilpatrick ${ }^{11},{ }^{12}$ distinguished the following types of projects: creative; consumer (connected with entertainment); projects on solving problems or intellectual complications; projects-exercises.

Since the proclamation of the social nature of learning by J. Dewey in his scientific work "Democracy and Education" (1916), the project design has been focused on socialization of the learning content based on the search for problems and questions in the surrounding life environment.

With the availability of the translation of W. Kilpatrick's book "Project Method" in the Soviet Union (1925), educational and pedagogical project design developed as a special form of pedagogical activity, but in 1931 already the Central Committee of the CPSU (b) the project method was disapproved because it "did not allow students to acquire a system of

\footnotetext{
${ }^{8}$ История педагогики и образования. От зарождения воспитания в первобытном обществе до конца ХХ в.: Учебное пособие для педагогических учебных заведений / Под ред.. А. И. Пискунова. M., 2001.

${ }^{9}$ Джуринский А.Н. История зарубежной педагогики: Учебное пособие. - М., 1998.

${ }^{10}$ Килпатрик В.Х. Метод проектов. - Л., 1925. - С. 42.

${ }^{11}$ Килпатрик В.Х. Основы метода. М.; Л., 1928. С. 334. Килпатрик, В. Х. (1930).

12 Воспитание в условиях меняющейся цивилизации. Москва: Работник просвещения (Kilpatrik, W. H. (1930). Education for a changing civilization. Moskow: Educator).
} 
knowledge in the field of specific learning courses”, and in the next more than half a century in the USSR, the project method was not used as independent one.

Unlike the USSR, in such countries as the United States, the United Kingdom, Belgium, Finland, Germany, Italy, Brazil, Holland, and many other humanistic approaches to education and J. Dewey's project method have gained popularity.

The project design concept by A. Makarenko who was at the beginning of development of the pedagogical thinking logic was actively used. He considered pedagogical project design as a necessary starting point in the organization of educational-learning process. "As it is impossible to construct a house without a project, in the same way it is impossible to educate the right people without having an idea of what qualities they should master. Only through project design one can foresee educational goals in organization of the objective process of children's education" ${ }^{\prime 13}$.

In 70-80's of the 20th century, scholars began to actively use the engineering terminology of project design in a pedagogical activity (G. Schedrovitsky, V. Kraevsky, I. Lerner). The concept of "project” in the methodology of pedagogical activity was used by G. Schedrovitsky in 1968 in his work "Pedagogy and Logic", and N.V. Kuzmina singled out a design component in the structure of the pedagogue's activity. Soviet pedagogy begins to operate with the concepts of "pedagogical project design", "teacher's project activity”, and “pedagogical project”.

In this historical period, pedagogical project design was seen as "a peculiar form of implementation and fixation of social goal-setting, where the project design is embedded in the system of pedagogical production. Therefore, it was about a peculiar and multi-tiered area in which the products of activity, having produced at the previous level, are transmitted to the next one and become either means or regulatory guideline" ${ }^{14}$.

O. Kobernyk's scientific research has shown that in 90s of the 20th century the study of the pedagogical project design problem was associated with the application of the project method to the complex development of pedagogical projects in national education and in such fields of knowledge as psychology, philosophy, valeology, and others. The researcher notes that social project design is a specific activity

13 Козлов И. Ф. Педагогический опыт А.С. Макаренко / И. Ф. Козлов. - М.: Просвещение, 1987. - $185 \mathrm{c}$.

${ }^{14}$ Коршунова Н. Л. Проекты и прожекты в педагогике / Н. Л. Коршунова // Педагогика. - 2003. № 5. - C. 4-9. 
associated with a scientifically grounded definition of the options for the scheduled development of social processes and phenomena and goaloriented change of specific social institutions. At the same time, in social sciences, project designing, as a rule, is considered as one of the forms of a forward-looking reflection of reality, the process of creating a prototype of a predictable object, a phenomenon or a process with the help of specific methods. Project designing is a concrete form of manifestation of the management prognostic function, when a probable image of the future material or ideal reality is created. The aim of project design is to predict objects, phenomena or processes that would meet the desired properties" ${ }^{\prime 15}$.

At the end of the $20^{\text {th }}$ and at the beginning of the $21^{\text {st }}$ century the scientists began to consider a project design as a special kind of thinking activity. Thus, the project design of social system development within the framework of methodology of thinking system activity was studied by O. I. Genisaretsky, V. M. Rosin, G. P. Shchedrovytsky, the implementation of a project design as a management procedure was developed by I.V. Bezstuzhev-Lada, M. I. Lapin, I. I. Lyakhov, B.V. Sazonov, Zh.T. Toshchenko; T. Batievska, V. Dokuchaeva, O. Kobernyk, O. ZairBeck, V. Slastionin, N. O. Masiukova, O. G. Prikot and others worked on the methodology of project designing in education.

The project activity in educational field gained a new impulse in 90's of the last century. The humanistic direction of pedagogical project design was outlined due to involvement of philosophical, cultural, and psychological knowledge in its methodology. The practical opportunities of project activity in education have been further developed in connection with the rapid development of information and communication technologies.

Later on, pedagogical project designing is spreading at the level of pedagogical systems, educational environment, personality, content of education and learning. A process of forming the project space for educational process participants is taking place.

The project methods in pedagogy are gradually being transformed into project learning or learning through project designing (for example, the textbooks of the well-known English teacher T. Hutchinson "Project English", "Hotline”, "New Hotline”, using problem-project design technology of learning). The project environment is transformed into an educational environment, and the use of logic of creating typical projects

15 Коберник О. Сутнісна характеристика проектування педагогічного процесу / О. Кобернік // Збірник наукових праць Уманського державного педагогічного університету. - 2012. - Ч. 2. - С. 101-109. 
serves as the main means of learning. Due to the fact that project design increasingly enters the educational space, there are opportunities for obtaining new scientific results within the educational system, forming the new social status of education as a source of new knowledge production. This requires the use of learning methods aimed at research and research-experimental methods.

The peculiarities of the current education state provide the necessity for mass assimilation of project activity foundations. The movement of community in the direction of continuous education leads to a constant change in the nature of motivation and necessary competencies at every life stage of personality. All educational process participants are forced to operate more volumes of information flows in order to keep up with modern trends in science and their areas of professional activity.

Today the priority in education is not assimilation of certain amount of knowledge, but orientation in a growing amount of information flows and production of knowledge which does not exist, but the need for which is realized by personality. The rapid "aging" of scientific data encourages the search for sources of new knowledge in the educational system directly. The project design can be such source definitely.

Shifting the priorities from the process of accumulating knowledge to information paradigm of education raises the question of what to teach exactly? The choice of educational content is transformed from the plane of the required amount of knowledge, skills and abilities in the task to distinguish between typical problems and tasks, the solution of which is necessary for life and professional activity. Thus, the projective nature of education content and methods of its construction is distinguished, and the ways of constructing the content of education become an integral part of its structure.

The previous system of education was oriented towards the carriers of ready-made knowledge, namely, scientists, tutors, teachers who passed on their knowledge to the students, and today, anyone can be the source of necessary information regardless of the level of education received. In the modern educational environment, persons who are trained are in the state when they must independently design their personal trajectories of motion in the information field (educational trajectories), independently designing the content of education and educational environment.

In the modern information society, education no longer serves as a basis for learning of ready-made knowledge, but it is transformed into a way of exchanging information in society. This is the exchange that takes 
place throughout the life of a person and involves not only assimilation, but also production of information. Thus, the increased attention to pedagogical project design is determined by the necessity of active development of projective imagination, thinking and way of action in the subjects of educational activity.

\section{The Main Concepts of Pedagogical Project Design}

What is the essence of concepts of "project", "project design", "pedagogical project design"?

In the process of considering pedagogical project design, we start out from a central concept - a project.

The project (from the Latin projectus - thrown forward) is a previously created image and description of an object that does not yet exist and have to be created. The description is not only complete and detailed, but also provides the necessary resources and mechanisms for implementing the idea.

From a philosophical point of view, the project is the result of human spiritual transformation activity (M. S. Kagan). From a standpoint of an activity approach, the project is considered as a goal and the result of project design and project activity. The material of projects is a variety of sign forms: theory, model, concept, formula, algorithms; and a theory of activity is the instrumental system of project design in various fields of human life.

In various sources one can find the definition of a pedagogical project as:

Idea, intention, plan, etc., that is project documentation, in conjunction with the practical implementation of measures in a controlled process ${ }^{16}$;

A complex of interrelated activities aimed at a purposeful change of the pedagogical system during a predetermined period of time, at the established budget with orientation to clear requirements for the quality of the results and specific organization ${ }^{17}$;

The developed system and structure of teacher's actions for realization of a specific task, specifying the role and place of each action, time of these actions, their participants and conditions necessary for the effectiveness of the whole system of actions (in the same source).

\footnotetext{
${ }^{16}$ Підласий І. П. Діагностика та експертиза педагогічних проектів: Навч. посіб. / I. П. Підласий. К., 1998. - C. 11.

${ }^{17}$ Колесникова И. А. Педагогическое проектирование: Учеб. пособие для высш. учеб. заведений / И. А. Колесникова, М. П. Горчакова-Сибирская; Под ред. И. А. Колесниковой. - М: Издательский центр «Академия», 2005. - С. 19.
} 
There are other definitions of the term "project" that can be correlated with educational activities:

The project is a set of design documents containing fundamental (draft project) or final (technical project) decision, which gives the necessary idea about the structure of the product being created and the source data for further development of the working documentation (technical documentation);

The project is "something that is being intended or planned, for example, a large enterprise” (Webster explanatory dictionary);

Project in lat., projet in fr. a plan, assumption; intended, planned matter and its layout in writing or in drawing.

Projeter in fr to intend at, think, make, realize and assume to be fulfilled; make a note, drawings for this (Dahl Dictionary).

Project design is an activity aimed at creating a project, prototype, prefigure of the future predicted object, phenomenon, state and methods of its production. In project designing a systematic approach is used which is to establish the structure of a system, types of links, attribute definition, environmental impact analysis ${ }^{18}$.

The overwhelming majority of human labor products are created due to previous planning - the process of creating a prototype, prefigure of the predicted object, the state preceding implementation of idea in a real product.

The basis of pedagogical project design is the main ideas of classical project design, which can be formulated as follows: a project design is a managed process representing a system with a complex internal structure; external environment has a great influence on the project design efficiency; managed project activity includes variant and invariant components; the systematic approach is the basis of project design; the effectiveness of project design is considered as the ratio between the effort made and the result.

It should be noted that today the theoretical and terminology basis of the project design has not been fully developed, which may lead to complications in the development of theoretical problems.

In scientific sources there are various interpretations of the essence of pedagogical project design: as a process of creating new forms of pedagogical activity, its content and technologies are understood as

${ }^{18}$ https://uk.wikipedia.org/wiki/\%D0\%9F\%D1\%80\%D0\%BE\%D0\%B5\%D0\%BA\%D1\%82\%D1\%83\% D0\%B2\%D0\%B0\%D0\%BD\%D0\%BD\%D1\%8F. 
pedagogical project design by V. A. Bolotov and V. V. Serikov ${ }^{19}$; as a process of creation of pedagogical projects by Borysova N. V. ${ }^{20}$; as a previous development of main details of future students' activity and pedagogues by V. S. Bezrukova ${ }^{21}$; as substantial, methodical, technical, psychological and organizational formulation of idea by E. M. Shiianov and V. O. Slastionin ${ }^{22}$; as the activity aimed at creating a project as an innovative model of the educational and learning system, consisting of such gradual stages as prediction, modeling, designing and implementation of the pedagogical project, is considered by the researcher T. Yu. Pobedova ${ }^{23}$.

Summarizing various definitions one can conclude that pedagogical project design is a specific type of activity aimed at creating a project. A project designing in pedagogy is understood as the creation of new technologies on the basis of forecast, the use of which should contribute to goal achievement.

\section{Principles, Types and Levels of Project Activity}

The rules governing the activities of the educational process participants in the project field are the principles of pedagogical project design. We will consider the basic ones.

The principle of predictability focuses on the future state of the project design object. It determines the difference between the actual and desired states of the project design object.

The principle of step by step nature provides step-by-step and gradual advancement to the project future, from the idea to forming the aim image and action algorithm, and then to the program of actions and its realization. It should be taken into account that the next action should be based on the results of previous actions.

The principle of normalization determines the necessity to complete all stages of the project creation within defined procedures.

19 Болотов В. А., Сериков В. В. Компетентностная модель: от идеи к образовательной програмне // Педагогика. 2002. № 9. С. 22-27.

${ }^{20}$ Борисова Н.В. Образовательные технологии как объект педагогического выбора: учеб. Пособие. М. 2000. 145 с.

${ }^{21}$ Безрукова В. С. Педагогика. Проективная педагогика: учеб. Пособие. Екатеринбург: Деловая книга. 1999. 329 с.

${ }^{22}$ Сластенин В. А., Исаев И. Ф., Шиянов Е. Н. Педагогика: учеб. пособие для студ. высш. пед. учеб. заведений / под ред. В. А. Сластенина. М.: Академия. 2002. 576 с.

${ }^{23}$ Подобедова Т. Ю. Теория и практика педагогического проектирования / Т. Ю. Подобедова // Проблеми сучасної пед. освіти: зб. статей / Кримськ. держ. гуманіт. ін.-т. - Ялта, 2004. - Вип. 6. - Ч. 2. С. 81-87. - (Серія: Педагогіка і психологія). 
The principle of effectiveness governs the project activity to obtain a result that has an applied significance. It stimulates pragmatism.

The principle of feedback determines the necessity to obtain information on the effectiveness of the project action at each stage of the project to further correct the following actions.

Principle of resource provision provides comprehensive, complete resource support for the whole process of pedagogical project design.

The principle of taking into account the cultural environment indicates the necessity to take into account the conditions of cultural environment where the pedagogical project design process takes place and the design results match the specific cultural patterns.

The principle of self-improvement states that solving some tasks in the process of pedagogical project design leads to the emergence of others that stimulate the development of new forms of project design.

Principle of pedagogical reflection states about the development of participants' ability in pedagogical project design to comprehend and rethink their own actions.

The success of pedagogical project design depends largely on participants' compliance with certain requirements. We formulate and briefly characterize them.

Reality is a guarantee of goal achievement of pedagogical project design. To implement this requirement, all participants in the project activity must have the appropriate competencies and must be provided with necessary resources.

Guidance is compliance with the project discipline determined by the necessity for regulation of participants' activities in pedagogical project design, technical definition of the procedures performed. An important element is the comprehensive information support of each project procedure achieved by the timely receipt of various source data.

One of the requirements is taking into account the diversity of participants' needs in pedagogical project designing. In the project design process, it is necessary to take into account educational needs and interests of various professionals and groups of people. It is compulsory to coordinate the value orientations and actions of all participants in pedagogical project design.

Interconnectivity is the functioning of educational systems associated with the necessity to take into account not only psychological and pedagogical but also economic, legal, philosophical, social and many other aspects. Pedagogical project design deals with interdisciplinary knowledge reflecting a wide range of diverse scientific research. During the project activity, participants have to analyze the entire educational 
context in which the project will be included. This is the content of education in general, all levels and forms of learning, regulatory norms, social situation and much more.

Activity is manifested in the voluntary inclusion and positive attitude towards the cognitive activity of participants in pedagogical project design. In the process of project activity, thoughts and suggestions of not only participants in pedagogical project designing but also other involved persons ready to participate in the discussion of project issues should be taken into consideration. The best result in pedagogical project design can be achieved by creating author teams involving people of diverse profile of activity.

Considering the interaction of nature, a person and society, we distinguish three main types of project design: natural, technical and social. Project designing in the field of education belongs to the social one.

G. P. Shchedrovitsky distinguishes two different types of pedagogical project design in a view of strategic planning: adaptation to the social environment and its conditions (a specific way of responding by educators to the social challenges of education), and improvement or transformation of environment in accordance with own values, goals and beliefs ${ }^{24}$.

V. I. Slobodchikov outlines two types of project design:

Psycho-pedagogical project design of educational processes, referring to learning as an assimilation of ways of activity; formation as an assimilation of the perfect action form; education as a growing up and socialization;

Socio-pedagogical project design of educational institutions and educational environment in which the corresponding processes are implemented (the same source).

V. P. Bederkhanova mentions a variety of practical project design options, also highlights two main areas. The first one involves the project design and creation of projects in intensive forms. This includes organizational-activity, innovation, productive games and designing meetings. The second one relates to the joint step-by-step project design of the educational process by all its participants, where the design process itself is considered as one of the factors of educational institution formation with humanistic orientation ${ }^{25}$.

${ }^{24}$ Колесникова И. А. Педагогическое проектирование: Учеб. пособие для высш. учеб. заведений / И.А.Колесникова, М.П.Горчакова-Сибирская; Под ред. И. А. Колесниковой. - М: Издательский центр «Академия», 2005. - 288 с.

${ }^{25}$ Бедерханова В. П. Становление личностно ориентированной позиции педагога. - Краснодар, 2001. - C. 168-178. 
According to I. A. Kolesnikova ${ }^{26}$ three main types of project activity is being developed actively, which are different in the object of transformation, goal-orientation and the result:

1. Socio-pedagogical project design is aimed at changing the social environment or solving social problems by pedagogical means. It is aimed at solving socially vital problems that people face in everyday life. It mainly performs the functions of pedagogical ordering of the sociocultural environment, identifying and changing external factors and conditions influencing human development, education, formation, and socialization. The result of socio-pedagogical project design becomes the basis for organizing more efficient functioning of educational systems, it thereby allows changing the potential possibilities of uncovering the pedagogical processes themselves.

2. Educational project design is focused on designing the quality of education and innovative changes in educational systems and institutes. Within the framework of educational project design, education development projects are being created in the state in general and in separate regions. Projects on both creation of educational institutions and reformation of educational management bodies are being implemented. Educational standards and educational content of all levels are formed.

3. Psycho-pedagogical project design is aimed at transforming the person and interpersonal relationships within the educational processes. It provides building up the models of processes related to the transformation of personality and interpersonal relationships based on the features of motivation, perception of information, learning knowledge, participation in activities, and communication. The pedagogical process as such; the conditions of effective learning and education, pedagogical technologies; the forms of participants' interaction in the educational process, the methods of self designing of personality is in the center of its attention.

According to I.A. Kolesnikova, the considered positions determine three main options for analysis and construction of the project context in the field of education: socio-cultural, psycho-pedagogical and educational.

In our opinion, the concept of "pedagogical project design" combines elements of all three listed types of a project activity.

\footnotetext{
${ }^{26}$ Колесникова И. А. Педагогическое проектирование: Учеб. пособие для высш. учеб. заведений / И. А. Колесникова, М. П. Горчакова-Сибирская; Под ред. И. А. Колесниковой. - М: Издательский центр «Академия», 2005. - 288 с.
} 
The project activity, depending on the requirements for the result and the forms of presentation of the final product, can be carried out at the conceptual, substantial, technological and procedural levels ${ }^{27}$.

The project activity at the conceptual level is aimed at creating a predictive imagination (model) of the project design object. The final result of the project activity at the conceptual level has a universal nature and can serve as a basis for similar products of the next level.

The final result of the project activity at the substantial level involves obtaining a product with properties that meet the functional purpose and the needs for its further use.

Project activity at the technological level makes it possible to specify a description of the action method in a particular environment.

The procedural level transfers the project activity into a real process in which the final product is fully ready for practical use.

The project activity at each of the specified levels can be extended to the object as a whole or to its individual components. With the transition from one level to another, the scale of the project activity and project tasks changes, the requirements for their solution and the forms of the product presentation are specified ${ }^{28}$.

\section{The Stages of Pedagogical Project Design}

Pedagogical project design involves conducting a series of consecutive stages by participants in the project activity. Scientists describe a variety of approaches to describing the project design stages.

V. O. Anischenko distinguishes the following stages of project design: analysis, synthesis and evaluation of the system object status; analysis, synthesis and evaluation of factors affecting the object state; directly the project design process; evaluation of the results of the pedagogical project study; realization of the proposed project in the mass practice $^{29}$.

N. O. Masyukova offers the following steps in the project design: diagnostics of reality (studying, conducting scientific research of various degrees); formation (actualizing, understanding, searching) of values,

\footnotetext{
${ }^{27}$ Колесникова И. А. Педагогическое проектирование: Учеб. пособие для высш. учеб. заведений / И.А.Колесникова, М.П.Горчакова-Сибирская; Под ред. И. А. Колесниковой. - М: Издательский центр «Академия», 2005. - 288 с.

${ }^{28}$ Машбиц Е. И. Психолого-педагогические проблемы компьютеризации обучения: (Педагогическая наука - реформе школы). - М.: Педагогика, 1988. - 192 с.

${ }^{29}$ Анищенко В. А. Методологические основы проектирования образовательных систем в условиях непрерывного профессионального образования [Текст] / В. А. Анищенко // Новые педагогические исследования. - 2006. - №: 3. - С. 47-58.
} 
goals of reality transformation; creation of the result image; step-by-step planning of joint actions aimed at achieving the project goal in time (preparation of the program); exchange, approval and correction of planned actions in the course of communication; complex examination of project implementation results ${ }^{30}$.

O. S. Zair-Beck considers pedagogical project design at the following stages: definition of idea or a draft sketch; development of action models (strategy); planning of real strategies at the level of tasks and conditions of implementation; organization of feedback; evaluation of the process; evaluation and analysis of results; drawing up the documents ${ }^{31}$.

V. E. Radionov outlines the preliminary stage; the stage of decomposition (division of the general idea into parts, other tasks) and selection of appropriate means; the stage of transformation on which the original idea is specified, finds the structure and specific content; the stage of convergence, where "putting together" of individual project decisions into programs takes place ${ }^{32}$.

We distinguish three basic stages of the pedagogical project design:

1. Preparatory stage;

2. The stage of project implementation;

3. Final stage.

In turn, each of these stages consists of certain internal procedures that form a structural, substantial, organizational, technological basis of the project activity. We should consider them in more detail.

During the preparatory stage, preconditions for pedagogical project design are created. The need for transformation of pedagogical reality may arise at the administrative level in the form of a certain social order, within a social group or a group of persons concerned, in consciousness of a certain personality. The ideas of the future object, subject, and goals of the project activity are beginning to form. A diagnosis of social reality is being conducted with the aim of finding out what exactly does not satisfy us in the surrounding environment, in people, in ourselves; what opportunities (pedagogical, social, psychological) and resources are available for the desired changes; what are the possible consequences of changes in the current state of things. It is reasonable to carry out the

\footnotetext{
${ }^{30}$ Масюкова Н. А. Проектирование в образовании : [Монография] / Н. А. Масюкова; М-во образования Респ. Беларусь. Нац. ин-т образования.- Минск : М-во образования Респ. Беларусь. Нац. ин-т образования, 1999. - 287 с.

31 Заир - Бек Е. С. Теоретические основы обучения педагогическому проектированию : диссертация ... доктора педагогических наук : 13.00.01. - Санкт-Петербург, 1995. - 410 с.

32 Радионов В. Е. Теоретические основы педагогического проектирования: дис. ... д-ра пед. наук. СПб., 1996. 352 с.
} 
preliminary project monitoring aimed at revealing the possibilities of quantitative and qualitative diagnostics of the real situation; revealing of weaknesses in the problems of the future pedagogical project activity; experimental confirmation of the need for a pedagogical project creation; outlining the target, time, financial, resource framework for the future project activity. Diagnosing the real state of things with the help of quantitative and qualitative parameters, the preliminary project monitoring outlines the boundaries of the future project design object.

The information received in the course of the preliminary project monitoring is generalized and arranged, and its further visualization helps to identify the subject of project design more accurately.

Organizers of pedagogical project designing aimed at establishing the pro-active activity of all project participants need to arrange the emergence of natural interest in the development of future project issues; freedom of search and access to necessary information; organization of the permanent exchange of information between the project activity participants; assist in generalizing and presenting the results achieved.

At the preparatory stage, it is also necessary to form an ideal image of the project design object that will act as a guide for future activities. Such image can be presented in the form of a model, an ideal and reflects the imagination of the project participants about a project activity final result.

The formulation of the project problems in the language of professional terms is essential. Definition of the project issues outlines the non-compliance between the real and the desirable, the unknown, which requires a common search. Formulation of the project issues gives an idea of the boundaries, scales, scope and structure of future project activities, highlighting priority areas, and building a tree of goals, which in turn will help in understanding the logic and sequence of actions in the pedagogical project design process.

An important element of the preparatory stage is the project activity systematization, which includes revealing the structure of the project design object, defining its main characteristics in general and individual components, clarifying the goals and formulating the tasks of pedagogical project design, selecting the criteria for assessing the project activity success.

In the process of systematization of preliminary project activity, the project idea is more clearly defined; a high level of project activity is motivated due to the project idea presentation by linguistic means (verbal description, drawings, computer programs, schemes, etc.). The creation of 
preconditions for the correct setting and developing of project design goals is also important. The goals and projected ideal project design results should be specific, realistic and aimed at solving the problems that have become impulses of the design process. The project design goals are supplemented by possible final results of the project activity for which it is necessary to develop criteria for their evaluation.

A conscious inclusion of project activity participants in a joint work is possible on the basis of a common understanding of the nature of the project design object, and this will require harmonization of the communication language, values, and the conduct of thinking activity based on categories and concepts. The clear definition of category, the concepts used to describe the phenomena and processes in pedagogical project design will influence the project text clarity.

The result of the preliminary project activity systematization is the joint proposal mutually agreed between the participants in pedagogical project design, based on a conscious choice of values, theoretical provisions, principles, and ideas identified as fundamental for this project.

At the preparatory stage the participants in the project activity have to formally draft the project.

The project format is a specific way of limiting (standardizing) the participants' activity in the project activity by defining its scope and scale. A substantiated choice of format includes the definition of time, space, context of the project, the circle of its participants and other necessary parameters. Their number may vary depending on the pedagogical situation and the project design goals ${ }^{33}$.

It should be taken into account that the design space should be harmonized with the scale of the project design subjects and available resources and capabilities.

In the future, the work of the project participants is aimed at planning the project activity. Planning is related to the development of a plan for achieving the goals and is of strategic nature. "The essence of planning as a managerial action is to outline the stages of achieving the intended goal through the definition of a number of intermediate products on the way to the final result" 34 .

\footnotetext{
${ }^{33}$ Колесникова И. А. Педагогическое проектирование: Учеб. пособие для высш. учеб. заведений / И. А. Колесникова, М. П. Горчакова-Сибирская; Под ред. И. А. Колесниковой. - М: Издательский центр «Академия», 2005. - 288 с.

34 Масюкова Н.А. Проектирование в образовании : [Монография] / Н. А. Масюкова; М-во образования Респ. Беларусь. Нац. ин-т образования. - Минск : М-во образования Респ. Беларусь. Нац. ин-т образования, 1999. - 287 с.
} 
A plan is a document providing meaningful guidelines for activities, defines its order, scope, time limits ${ }^{35}$. The planning of the project activity involves the division of the design procedure into individual components and consideration of possibilities of the integrated provision of each of them. Participants in the project activity may use a variety of schemes for the regulation of project activities and the establishment of feedback. In the process of pedagogical project design, the initial idea of the project is systematically specified at the level of images of the goal and the anticipated result, and on the basis of this, the plan of participants' joint actions in the project activity is specified.

The project submission completes the preparatory stage. It is essential to outline the requirements for project submission forms. After that, the participants in the pedagogical project design begin to implement the project.

At the project implementation stage, each participant should know where, who and in what form, can provide assistance and support in case of difficulties in the process of project implementation. To that end, it is necessary to establish and maintain a permanent feedback system between all participants in the pedagogical project design. An important element in the project implementation process is the ongoing mid-term evaluation of the results obtained and the project correction on their basis. This mid-term evaluation should be based on predefined criteria of the project activity success. It is important to provide procedures for approbation of the project (both within the given conditions and in the variations).

The final stage of pedagogical project design involves conducting an examination which will allow establishing the conformity of the result obtained to the pre-set goals. Evaluation of the project activity results can be carried out with the help of independent experts, by self-evaluation of the project results and the defined criteria, by reflection of success of the joint project activity.

Pedagogical project design participants should think about their further steps among which they can proceed to the development of a new project; cooperate with other similar projects; start the activity of a new organization on the basis of the completed project; expand territorial coverage by the created project.

${ }^{35}$ Колесникова И. А. Педагогическое проектирование: Учеб. пособие для высш. учеб. заведений / И. А. Колесникова, М.П.Горчакова-Сибирская; Под ред. И. А. Колесниковой. - М: Издательский центр «Академия», 2005. - 288 с. 
Each of the outlined stages of pedagogical project design is part of educational process, where, along with the practical implementation of the project activity result is the formation of values, guidelines of the project activity participants, development of their communicative and creative abilities, and creativity.

\section{CONCLUSIONS}

The processes which meet the needs of people in education, closely connected with the implementation of modern technological processes, provide training of specialists who are capable of working with new types of activities are in the center of pedagogical project design. The goals and content of the educational process aimed at development of professional competences, general and professional culture are being renewed. The pedagogical project design develops personal structures of its participants actively, stimulates them to self-improvement; and their direct participation in the project becomes a form of mastering a variety of competencies, experience of joint activity.

\section{REFERENCES}

1. Анищенко В.А. Методологические основы проектирования образовательных систем в условиях непрерывного профессионального образования [Текст] / В.А.Анищенко // Новые педагогические исследования. - 2006. - № 3. - С. 47-58.

2. Бедерханова В.П. Становление личностно ориентированной позиции педагога. - Краснодар, 2001. - С. 168-178.

3. Безрукова В.С. Педагогика. Проективная педагогика: учеб. Пособие. Екатеринбург: Деловая книга. 1999. 329 с.

4. Болотов В.А., Сериков В.В. Компетентностная модель: от идеи к образовательной програмне // Педагогика. 2002. № 9. С. 22-27.

5. Борисова Н.В. Образовательные технологии как объект педагогического выбора: учеб. Пособие. М. 2000. 145 с.

6. Воспитание в условиях меняющейся цивилизации. Москва: Работник просвещения (Kilpatrik, W. H. (1930). Education for a changing civilization. Moskow: Educator).

7. Джуринский А.Н. История зарубежной педагогики: Учебное пособие. - М., 1998.

8. Дистерверг А. Руководство для немецких учителей. - Изд. Т. Тихомирова, 1913. 
9. Докучаєва В.В. Проектування інноваційних педагогічних систем: теоретико-методологічний аспект / В.В. Докучаєва // Андрагогічний вісник. - 2014. - № 5. - С. 37-46.

10. Заир - Бек Е.С. Теоретические основы обучения педагоггическому проектированию : диссертация ... доктора педагогических наук : 13.00.01. - Санкт-Петербург, 1995. - 410 с.

11. История педагогики и образования. От зарождения воспитания в первобытном обществе до конца XX в.: Учебное пособие для педагогических учебных заведений / Под ред. А.И. Пискунова. - М., 2001.

12. Каган М.С. Философия культуры. - СПб., 1996. - С. 240.

13. Килпатрик В.Х. Метод проектов. - Л., 1925. - С. 42.

14. Килпатрик В.Х. Основы метода. М.; Л., 1928. С. 334. Килпатрик В. Х. (1930).

15. Коберник О. Сутнісна характеристика проектування педагогічного процесу / О. Кобернік // Збірник наукових праць Уманського державного педагогічного університету. - 2012. - Ч. 2. С. 101-109.

16. Козлов И.Ф. Педагогический опыт А.С. Макаренко / И.Ф. Козлов. - М.: Просвещение, 1987. - 185 с.

17. Колесникова И.А. Педагогическое проектирование: Учеб. пособие для высш. учеб. заведений / И.А. Колесникова, М.П. Горчакова-Сибирская; Под ред. И.А. Колесниковой. - М: Издательский центр «Академия», 2005. - 288 с.

18. Коменский Я.А. Великая дидактика / Пер. А. Щекинского. M., 1893. С. 138.

19. Коршунова Н.Л. Проекты и прожекты в педагогике / Н.Л. Коршунова // Педагогика. - 2003. - № 5. - С. 4-9.

20. Масюкова Н.А. Проектирование в образовании : [Монография] / Н. А. Масюкова; М-во образования Респ. Беларусь. Нац. ин-т образования. - Минск : М-во образования Респ. Беларусь. Нац. ин-т образования, 1999. - 287 с.

21. Машбиц Е.И. Психолого-педагогические проблемы компьютеризации обучения: (Педагогическая наука - реформе школы). - М.: Педагогика, 1988. - 192 с.

22. Підласий І.П. Діагностика та експертиза педагогічних проектів: Навч. посіб. / І.П. Підласий. - К., 1998. - С. 11.

23. Подобедова Т.Ю. Теория и практика педагогического проектирования / Т.Ю. Подобедова // Проблеми сучасної пед. освіти: 
зб. статей / Кримськ. держ. гуманіт. ін.-т. - Ялта, 2004. - Вип. 6. Ч. 2. - С. 81-87. - (Серія: Педагогіка і психологія.

24. Радионов В. Е. Теоретические основы педагогического проектирования: дис. ... д-ра пед. наук. СПб., 1996. 352 с.

25. Руссо Ж.Ж. Эмиль, или О воспитании. - М., 1996. - С. 211.

26. Сластенин В.А., Исаев И.Ф., Шиянов Е.Н. Педагогика: учеб. пособие для студ. высш. пед. учеб. заведений / под ред. В.А. Сластенина. М.: Академия. 2002. 576 с.

27. Ягодовский К.П. Исследовательский метод в школьном обучении. - М.; Л., 1929. - С. 64.

28. Dewey J. Experience and Education. - N. -Y., 1938.

29. https://uk.wikipedia.org/wiki/\%D0\%9F\%D1\%80\%D0\%BE\%D0 \%B5\%D0\%BA\%D1\%82\%D1\%83\%D0\%B2\%D0\%B0\%D0\%BD\%D0\% $\mathrm{BD} \% \mathrm{D} 1 \% 8 \mathrm{~F}$.

Information about the author: Radomsky I. P. Candidate of Pedagogical Sciences, Assistant Professor, Director of Educational-Scientific Center of the Educational and Learning Process Arrangement of the V. I. Vernadsky Taurida National University 33, J. McCain str., Kyiv, Ukraine 


\section{MODERN PSYCHOLOGICAL AND PEDAGOGICAL TECHNOLOGIES FOR THE DEVELOPMENT OF STUDENTS' CREATIVITY}

\section{Vynohradova V. Ye.}

\section{INTRODUCTION}

In modern conditions of development of the state, the issue of the development of creativity of the Ukrainian citizens becomes topical. Not only the development of IT technologies, but also creative industries coming to the fore. Creative activity has a social character; therefore, scientists from various fields are engaged in its problems. Accordingly, the problem of creativity, training and education of a creative person, stimulation of creative work is important in the state policy.

In psychological science, an important place is occupied by the question of the formation and development of a creative personality. Undoubtedly, it is important to pay attention to the conditions of his or her formation and development during training. In particular, in the student period, during professional self-determination and selfdevelopment, the technologies of development of creative thinking matter. In this regard, the development of a creative personality is really of great importance both for the state and for the self-realization of a particular person. After all, scientific and technical progress is increasingly putting forward new socially significant benchmarks in the system of higher education and dictates new requirements for the graduates of higher educational establishments, their professional and personal qualities. The hopes for progressive changes in society, which are simply impossible without the full development of a creative personality, are namely laid on the student youth.

The relevance of the study is conditioned by the need for theoretical generalization of modern pedagogical approaches, significant factors affecting the development of students' creative thinking. There is an urgent need to stimulate the development of creative abilities, flexibility, speed of thinking based on the use of psychological and pedagogical technologies that provide students with independent activity in the educational process and systematic educational work in a creatively developing environment. 
An important contribution to the study of this problem made the scientific works of such leading researchers in this field as E. Torrens, E. E. Tunic, J. Gilford, A. M. Matyushkin, V. O. Molyako, V. I. Barko, Ye. L. Gergel, I. M. Bila, O. I. Bedlinskyi, V. M. Druzhynin, Ye. Sokolov, D. Kolyesov, O. I. Kulchytska, N. S. Leites, R. O. Semenova, B. M. Teplov and others. In the context of fundamentalism and humanitarization, which are the main strategic directions for the development of a higher education institution, the ways to improve vocational training are being defined, in particular, the training of a specialist who is able to make effective decisions based on creative thinking, who combines high professionalism with the socio-psychological qualities of a humanist. For the development of students' creative giftedness there is a need to create favourable social and psychological conditions, since the creative potential can be simply unnoticed or blocked, as a result of which it can be realized at an insufficient level or cannot be used at all.

\section{Theoretical analysis \\ of students' creative thinking development}

Today, the question of the formation and development of the student's personality has become one of the central issues in Ukrainian psychological and educational science. The learning process should ensure that students develop new competencies, knowledge and skills that they need for professional growth. One of the competencies of a modern specialist is creativity.

In creative work both social and personal factors, in particular the psychological qualities of a person, his or her character, willpower, ingenuity, passion, experience, intelligence, intuition, imagination, and so on, take on special significance. An important condition for creativity is the perception of new ideas, the ability to find and raise problems, the independence of behaviour and judgment and at the same time the ability to give in and abandon their previous thoughts, criticality, courage, and tolerance. Purposefulness, perseverance, the ability to ensure the regularity and rhythm of mental work are usually considered to be an important subjective condition for creativity.

The resulting quality of creative thought does not depend only on consciousness, but also on unconscious ideas, impulsive guesses, which perform the function of impulse regarding valuable associations. These factors of creativity give rise to a variety of theoretical ideas about the creative process. 
Such Ukrainian scientists as V. Molyako, A. Muzyka, T. Ravlyuk, V. Bondarovskaya, I.Bila, T. Gorobets-Chmut, M. Smulson and others have reached a significant level in the study of creative thinking.

V. Molyako, revealing the essence of creativity from the standpoint of psychology, notes that "by creativity they understand the process of

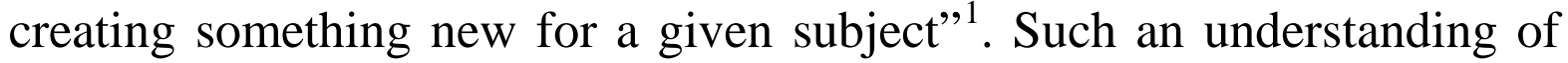
creativity indicates the possibility of finding mechanisms for the development of creative activity as early as in childhood. According to scientists, inventions are one of such mechanisms. In O. Muzyka's invention-strategic model of development of a creatively gifted personality the concept of invention (from the Latin word inventio fiction) is reflected as a natural way of developing creativity. Inventions are considered as spontaneous deviations in the course of activity arising in the process of imitation. Awareness and the use of inventions for the purpose of obtaining a creative result is one of the mechanisms for the spontaneous development of creativity and creative abilities.

Creativity itself is always connected with the creation of something original, unique, individual. The act of creativity, in contrast to actions based on the use of already known techniques and rules that lead to predetermined results, always means finding a completely independent way to achieve the goal. Creativity includes a moment of unpredictability, uncertainty; it is filled with fantasy, intuition, freshness of novelty. The ability for unexpected decisions and for an unusually deep comprehension of reality sharpens in a personality. This very particular stage of inspiration of ordinary professional receptions and rules forms readiness for unexpected turns, which are manifested in the ability to act in completely unpredictable circumstances. A special dynamism of all personality's traits that can be realized in a particular creative act becomes the inner hankering for creativity.

The student period is an important stage in the formation and development of an individual as a whole. It is also important in the development of a person's creative thinking. The peculiarities of manifestation of creativity in the student period are quite contradictory. During this period, the student solves mental problems relatively easily, quickly and efficiently. He or she is able to abstract from concrete quite easily, from visual material and to reflect in verbal terms. On the basis of the general data, he or she builds hypotheses, checks or rejects them when

1 Здібності, творчість, обдарованість: теорія, методика, результати досліджень: Колективна монографія / За ред. В. Моляко, О. Музики. - Житомир: Рута, 2006. - 320 с. 
solving mental problems. Facing the need to solve a problem that is new, in most cases the student seeks to use different approaches to its solution, seeking to find the most effective one. A student's thinking is at the level of formal operations and hypothetical reasoning. The thinking of this age group is abstract and systemic, it is reflexive, and students are able to understand the processes of their own thinking, mental, speech and mnemic strategies. Students are able to manifest flexibility, plasticity; they are ready for changes and discoveries, for cooperation. The thinking of this age category is distinguished by flexible transitions in the relationships of the figurative, logical, and operative components.

One of the main characteristics of thinking at this stage of the development is the complex nature of mental operations with a high level of integration of various types of thinking. For example, the results of theoretical thinking are verified by practice, under the influence of which the enrichment of theoretical thinking takes place too. At the same time, practical thinking associated with the situation which is directly perceived, is repelled from the concepts of theoretical thinking.

In parallel with the development of thinking, imagination and attention develop, which are favourable factors for the manifestation of creativity too ${ }^{2}$. The student forms his or her personal opinion, position selected by himself or herself. The student has great creative potential that needs to be developed and which cannot be allowed to die out. For thinking, as a higher mental process, the activity in which a person is engaged is really essential. Classes of creative activity are a prerequisite for the formation of students' skills and abilities to solve problem tasks set before them.

Creativity itself is always related to the creation of something original, unique, individual. The act of creativity, in contrast to actions based on the use of already known methods and rules that lead to predetermined results, always consists in searching for a completely independent path to achieving a goal. Creativity includes a moment of unpredictability, uncertainty; it is filled with fantasy, intuition, freshness of novelty. The ability for unexpected decisions, an unusually deep comprehension of reality is sharpened in a personality. This very particular stage of inspiration of the ordinary professional receptions and rules forms readiness for unexpected turns, which are manifested in the ability to act in completely unpredictable circumstances. A special

${ }^{2}$ Кривопишина О. А. Психологія творчості [Текст] / О. А. Кривопишина. - Суми: СумДУ, 2009. $-81 \mathrm{c}$. 
dynamism of all personality's traits that can be realized in a particular creative act becomes the inner hankering for creativity.

It is possible to speak about professional development only in cases when a person is aware of participation and responsibility for everything that happens to him or her, and tries to actively promote or resist external circumstances, plan and set goals for professional activity, changing oneself in order to achieve them.

Malimon V.I. identifies five areas of formation and development of a student as a creative personality ${ }^{3}$.

1. The development of a student's personality with a life orientation "to be," not "to have."

1. The mindset "to be", according to E. Fromm, means "to be renewed, to grow, to be poured out, to love, to break free from the walls of one's isolated "Self", to have deep interest, to go to something sensually, to give away" 4 . So, the educational process should be aimed at overcoming egocentrism, at updating the structure and content of education.

2. Comprehensive development of a student's personality.

The system of higher education should prepare a universal person, whose goal and purpose should be "integral knowledge" and "integral world”, about which our compatriot V.I. Vernadskyi wrote at the beginning of the twentieth century. Therefore, a need for a "holistic integral study of the individuality arises," notes V. Merlin. The solution of any practical problem in relation to a person is the most complete and accurate only when the whole variety of conditions is taken into account, determining the activity of a person and, consequently, the diversity of those individual peculiarities of a different hierarchical level on which this activity depends ${ }^{5}$.

3. The priority of the spiritual and moral development of the student's personality.

The process of developing a student's personality should be based on the world's best cultural achievements of mankind, self-awareness as part of this culture and the formation of one's own cultural world.

4. Free development of the student's personality.

The student must cultivate his or her intellect and rational forces. As the French educator and thinker N. Lebel rightly notes on this, "you need to slowly but persistently bring students through thinking, manual work,

${ }^{3}$ Малімон В. І. Перспективи формування та розвитку студента як творчої особистості / В. І. Малімон // Вища освіта України. - 2006. - № 1. - С. 142-145., с. 144.

${ }^{4}$ Фромм Э. Иметь или быть. 2 изд., доп. - М.: Прогресс, 1990. - 180 с., с. 94.

${ }^{5}$ Там само. - C. $142-145$, с. 118. 
knowledge acquisition, to scientific research, to choosing the proper behaviours and self-care, to teach to see, listen, think, reflect, have a clue about the hierarchy of the meanings of eternal values"6. The student has the right to choose in the learning process and teachers should tke this into account.

5. Formation of noospheric thinking in students in the process of studying at a higher educational establishment.

Humanitarian training should be focused on the formation of a specialist with a broad outlook, knowledge of history, culture, philosophy and the foundations of the state formation, with developed feelings of civic consciousness and responsibility, formed by moral and ethical values and principles and norms ${ }^{7}$.

For the formation of creativity as a personal, and not only behavioural properties, a specially organized environment is required. The so-called "local" methodologies of developing creativity (for example, performing non-standard tasks) are certainly useful. But as a result of their use, students often only learn some new ways of doing the task and subsequently reproduce learned actions (for example, teams in intellectual competitions compete in a special way). In such cases, creativity manifests itself in response to external influences, in certain circumstances, and not as a result of the subject's personal needs. That is why for the formation of creativity as a personal trait, a special environment providing a diverse systemic effect on a student, is required.

Psychological and pedagogical conditions that influence the formation of the experience of creative thinking can be divided into two groups: objective (situational) and subjective (personal). Subjective conditions are stable traits of a person's character, capable of influencing the states caused by a particular situation. Objective conditions include such environmental conditions, such organization of the educational process where students' initiative of is not suppressed, confidence in their strengths and capacities is formed in them, independence is stimulated and imagination is developed. Subjective (personal) conditions are a set of personality characteristics, influencing which (with the help of pedagogical techniques, methods, and means), experience of creative thinking of future specialists is formed. Objective (situa-

\footnotetext{
${ }^{6}$ Дзвінчук Д. Формування позитивної мотивації студентів при вивченні гуманітарних дисциплін в технічному університеті // Проблеми викладання гуманітарних дисциплін у технічних навчальних закладах. Матеріали регіональної науково-методичної конференції. - Івано-Франківськ, 2001. - С. 5-8, c. 113.

${ }^{7}$ Там само.
} 
tional) conditions provide the possibility of a purposeful pedagogical (formative) action, and also orient him or her in accordance with the goals set. This combination includes the following components ${ }^{8}$ :

a) Personality and behaviour of a pedagogue. The pedagogue acts as the main character of the technological process, he organizes it, provides concrete practical interaction with students, including them in the generally accepted system of values, strengthens the students' motivational support, activates their creative potential. The students' creative activity increases when the teacher shows his or her own creativity. The pedagogue should be able to create the conditions and carry out actions in order to cause the necessary and planned changes in the students' consciousness, thinking, behaviour and relationships; the teacher's functions include a real assessment of students' activities, because the rewards and punishments themselves form and reinforce the habit; the teacher should be the model, the example of a creative person, to whom students may and want to orient in their activities;

б) Material and technical base. Knowledge forms the basis of any professionally significant qualities, any abilities and skills. Mastering the necessary knowledge by students is one of the most important tasks of the educational process. To obtain a sufficient amount of knowledge, students should not only have an interest in the educational process and the skills of independent teaching and research activities, but also have the appropriate means. These include literary funds, computer software, the ability to use information bases on the Internet, and access to the cultural values of society;

в) The organization of the educational process. The organization of the educational process aimed at shaping the experience of professional and creative thinking should be characterized by problematicity. The necessity to resolve the contradiction between the presence of a problem and the impossibility of solving it under certain conditions induces the student to have a need for additional information and, therefore, affects the motivational sphere of his or her personality, forming cognitive needs.

So, the process of formation of creative thinking experience in students consists in purposeful interaction, co-creation of a pedagogue

\footnotetext{
${ }^{8}$ Иванова И. П. Развитие творческого мышления студентов в условиях проблемнодеятельностного обучения / И. П. Иванова. - Ставрополь, 2002.
} 
and a student in adequate specially organized conditions with the use of necessary mechanisms, forms and methods of organizing classes.

It should be noted that the development of creative abilities requires a long influence and should be the subject of attention of teachers from the first days of students' training. In our opinion, it is necessary to pay attention to rearing of hankering for creativity at all the stages of training.

Based on the abovementioned, as well as taking into account the requirements of the labour market, it can be concluded that there is an objective need for training polyfunctional specialists.

\section{The influence of the educational process peculiarities on the development of students' creativity}

In modern conditions, there is an increasing social demand for a specialist who is able to orientate oneself in a modern multicultural space, make reasonable management decisions, take care of other people subjects of communication, and the like. However, at this stage of development of the society, in the unstable conditions formed in the educational system, many of its parties, both pedagogues and students, experience crisis periods in training. Unfortunately, today obsolete approaches to training may be observed, and also very often prospective students make an unconscious or random choice of a speciality, which affects their learning motivation and the quality of higher education in general. We present some problems that hinder the development of creative abilities and the formation of students' creativity.

1. Reducing learning motivation in terms of a formal approach to the presentation of educational material. Unfortunately, students often come after school without any desire to study. They are accustomed to a consumer position to perceive information and not to be responsible for their knowledge. Our research shows that less than $10 \%$ of students conduct self-checking of the homework done. Therefore, they completely rely on the teacher and his assessment. Thus, it is necessary to form students' personal responsibility for learning.

2. The absence of students' vision of a further perspective in the application of purely theoretical knowledge, which is often out of tune with the necessary requirements for employment.

3. Obtaining a formal education due to the pressure of relatives, families, "for show", "it is fashionable to have a higher education", etc.

4. The deficit of practice in the learning space. In fact, many students say that practical classes are held in artificial (classroom) conditions, without immersing directly into the sphere of their future profession. 
5. The presence of stereotypical perception by many teachers as for the students (expert, prevailing position), the fear of appearing incompetent in the manifestation of a democratic approach to teaching material, the fear of losing the usual framework for conducting classes, complications of the knowledge transmission ways, pressure from management. The emphasis on rigid subordinate positions of "teacherstudent" as "senior-junior", which leads to subjective distancing of both sides of training and the emergence of ostentatious obedience or resistance to the entire educational process.

6. The personal barriers of the students themselves: "it's not allowed, it's not accepted" to ask teachers "superfluous" questions, to communicate in an "equal" position (even in the case of age-related, social, and intellectual equality), risking to provoke their condemnation, disapproval of their peers, classmates.

7. The absence of well-coordinated work of public services and educational institutions that are responsible for the objective presentation of information about the professions necessary for the country and the demand for jobs caused by the desire to maintain themselves in the educational market, not to lose a source of income, and the like.

8. Low material base of the majority of higher educational establishments in Ukraine, which leads to limited access for students to acquiring practical skills during laboratory classes.

Therefore, it should be noted that in the complexities of the educational process of training specialists, not only the immediate interacting parties of the teacher and the student take part, but also other equally important components of this process: government structures, higher educational establishment management, students' families and teachers, close social environment, reference groups and many others, that is, a holistic educational ecosystem.

Thus, by all the listed features, the current state of the system of professional training of future specialists does not always contribute to the development of creative abilities and the formation of students' creativity. However, today most professions often require taking non-standard and fast decisions, therefore a person who graduates must necessarily develop his or her creative abilities. It should be noted that for the leader of any level, creativity is a necessary component of the profession.

A department is the main structural educational and scientific subdivision of a higher educational establishment. The quality of the educational process and the ability of future specialists to become competitive in the labor market depends on the effectiveness of its work. 
In our opinion, it is necessary to determine the main focus areas of the department, which influence the formation of the students' creativity.

1 . The graduating department prepares the curriculum, according to which the educational process is carried out. Today, taking into account new standards in which such competencies as creativity in solving issues are outlined, it enables higher educational establishments to select and design a pedagogical process according to any model, including the author's one. That is, the department, based on a specific scientific school, can determine the direction of the specialists' development, choosing disciplines and forms of training classes.

2. Each teacher prepares training work programs. They must meet general requirements, such as: modernity of knowledge, the connection of theory with practice, they must contain practical exercises (tasks, problems), a student's independent work (result), a list of references, links to the Internet editions. These programs are necessary not only for teachers, but also for students for their independent work.

3. Also important is the choice of teaching methods. It is proved that passive teaching methods (a lecture, preparation of reports) have a low level of acquisition of knowledge. But active learning methods such as discussion, debate, case study, business ones, role-playing, simulation games, brainstorming, participatory methods, a round table, working on joint projects have a high level of knowledge learning. So, teachers must shift from passive forms of education to active ones.

4. I would also like to note the joint activities of teachers of a graduating department. In our opinion, only uniform requirements, a unified position of all teachers can bring the best results in the training of young professionals. That is, a peculiarity of the department's staff is that the individual efforts of teachers will not bring the desired success if they are not coordinated with the actions of others. So, one of the main tasks of the head of the department is to create a team of like-minded people.

It should also be noted that the general concept of training specialists should have a humanistic focus, fundamental, scientific, general cultural, practical content of a specialist's training, taking into account his individual characteristics and potentials. It is necessary to create conditions for the implementation of an individual approach to each student. That is, it is important for teachers to take into account the properties of the cognitive and personal sphere, the creative potential of future specialists, as well as to carry out psychological support of the educational process. 
V.I. Vernadsky Taurida National University trains future specialists in the specialities of a classical university. In the process of learning our students have the opportunity to develop such qualities as flexibility, accuracy, originality of thinking, the ability to solve issues quickly and non-standardly, the ability to solve problematic issues and situations. Students have these opportunities both during professional classes and due to participation in the creativity training. This discipline is selective, but it gives the opportunity to develop the qualities necessary in life and work. During classes, students can determine their level of creativity, realize creativity in them and develop it, realize and overcome barriers that restrain creative potential. They can also form the skills and abilities to manage the creative process.

The main objective of the course is to update the creative abilities, creative personal potential of future specialists, to enhance the process of creating the personal and creative style of professional activity based on self-esteem, self-motivation and self-management.

The task of the course is the students' awareness of the creative nature of their own professional activities, understanding of their individual peculiarities, the level of development of personal abilities for managerial activities, other professionally significant qualities, mastering the mechanisms of creative self-realization in professional activities, strategies for the creative protection of the individual, ways of professional self-improvement, acquiring of knowledge and practical skills of organizing professional activities as a developing interaction aimed at enhancing the staff's creative activity.

It should be noted that in the process of personal development a larger role belongs to the teacher, who is able to direct students on the path of searching, to arouse a passion for searching in them. A teacher helps future specialists to enter the atmosphere of creativity, the circle of ideas, the work at which opens up broad opportunities for independent search. However, the problem of teaching creativity, preparation for professional creative activity is unusual - how to teach what you don't know, that is, something new, creative. The idea of a "free" upbringing, a "spontaneous" development of creativity originated from here. So, it is impossible to teach creativity directly in the usual sense of the word "teaching". In order to describe the processes of the formation of creative abilities, the concept of training impact is used. In this case, it is said about intellectual training. This is a system of flexible influences on the personality, aimed at the formation of abilities to creativity. 
The methods of searching for new solutions are divided into: group and individual. Among the group methods we should note "brain storming" of F. Osborne, the syectics of J. Gordon, creative discussion and the like. The socio-psychological aspect of organizing a creative group has a fundamental role in group methods of searching for new solutions. Among individual or combined methods we can mention the generalized heuristic method by O. M. Polovinkin, the method of association garlands, or metaphors, the "method of the sevenfold search" by G. Ya. Bush and the method of "morphological analysis" by F. Zwickey.

In our opinion, the awareness of a person of his or her potential, the prospect of personal and professional growth encourages a person to constant experimentation, that is, to creativity.

The educational training of these specialists should contribute to the development of individuality, the formation of the personality, the upbringing of socially active citizens capable of conscious life choices, as well as meeting the needs of society and the state for highly qualified specialists who would be able to enrich the intellectual, cultural potential of the Ukrainian people with their knowledge, skills, and moral qualities.

Creative training systems, as a rule, contain a combination of many methods, but they are not focused on a specific result, but on an impetus to creativity. At the classes dedicated to the development of creativity, it is necessary, first of all, to create a free gaming atmosphere aimed at ensuring the comfort of communication, confidence in one's strengths, one's own and group members' creative potentials.

In our opinion, the awareness of a person of their potential, the prospect of personal and professional growth encourages him to constant experimentation, that is, creativity.

In creativity, both social and personal factors, in particular the psychological qualities of a person, his or her character, willpower, ingenuity, passion, experience, intelligence, intuition, imagination, and so on, take on special significance. An important condition for creativity is the perception of new ideas, the ability to find and raise problems, the independence of behaviour and judgment and at the same time the ability to give in and abandon their previous thoughts, criticality, courage, and tolerance. Perseverance, insistence, the ability to ensure the regularity and rhythm of mental work are usually considered an important subjective condition of creativity.

The resultative character of creative thought does not depend not only on consciousness, but also on unconscious ideas, impulsive guesses, 
which perform the function of impulse regarding valuable associations. These factors of creativity give rise to a variety of theoretical ideas about the creative process.

Consequently, the task of the teacher is to actively include each student in practical types of creative activity at higher educational establishment, to create conditions for creative freedom in choosing the type of activity, sources, and the embodiment of their findings. Summarizing the abovementioned, it can be affirmed that the modern unstable, crisis state as a transitional period of the society development, including in the field of education, training of specialists, requires the active involvement of the main principles of humanization, individualization in the interaction process of the holistic educational system.

However, in our opinion, the development of creative abilities requires a long-term influence and should be the subject of attention of teachers from the first days of the students' training. In our opinion, it is necessary to pay attention to rearing of hankering for creativity at all the stages of training.

\section{CONCLUSIONS}

Thus, the general concept of training future specialists has a humanistic orientation, fundamental, scientific, general cultural, practical content of students' education, taking into account their individual characteristics and potentials. That is, it is necessary to create conditions for the implementation of an individual approach to each student, to take into account the properties of their cognitive and personal sphere, creative potential.

The educational training of these specialists should contribute to the development of individuality, the formation of the personality, the upbringing of socially active citizens capable of conscious life choices, as well as meeting the needs of society and the state for highly qualified specialists who would be able to enrich the intellectual, cultural potential of the Ukrainian people with their knowledge, skills, and moral qualities.

Psychological and pedagogical conditions conducive to the development of creative thinking consist of the teacher's choice of the forms, methods, means of education, as well as the items that are offered by the educational institution. An important factor is the organization of the educational process, when students' initiative is stimulated, confidence in their strengths and capabilities is formed in them, independence is supported and imagination is developed. That is, training 
activity contributes to the development of a personality with such inclinations that would meet the requirements of modern society - that is, specialists who possess a high level of intelligence, knowledge, skills, and who would be able to solve applied problems successfully. Only individuals whose creative thinking is developed can satisfy such requirements. So, taking into account the requirements of the labour market, it can be concluded that there is an objective need for training polyfunctional specialists.

\section{SUMMARY}

The article reveals the complex process of developing a student's creative personality. The most significant factors influencing the development of creative thinking of an individual when studying at a higher educational establishment have been considered and analysed. The main factors of stimulating the development of creative abilities have been determined on the basis of the personality-oriented nature of the teacher's interaction with students, the use of psychological and pedagogical technologies that ensure students' independent activity in the process of creative work and the systematic nature of academic work with students in a creatively developing environment. It has been found out that creative abilities develop in the conditions which stimulate this process.

It is said about the creativity training, which is held at V.I. Vernadsky Taurida National University. The areas for the student's development as an individual have been provided. The importance of developing the young professionals' creativity in modern Ukraine has also been emphasized.

\section{REFERENCES}

1. Андреев B.A. Диалектика воспитания и самовоспитания творческой личности. - Казань, 1998.

2. Дзвінчук Д. Формування позитивної мотивації студентів при вивченні гуманітарних дисциплін в технічному університеті // Проблеми викладання гуманітарних дисциплін у технічних навчальних закладах. Матеріали регіональної науково-методичної конференції. - Івано-Франківськ, 2001. - С. 5-8.

3.Здібності, творчість, обдарованість: теорія, методика, результати досліджень: Колективна монографія / За ред. В. Моляко, О. Музики. - Житомир: Рута, 2006. - 320 с. 
4. Зязюн Л. Академічні виховні цінності в системі освіти Франції // Вища освіта України. - 2005. - № 1. - С. 110-116.

5. Иванова И. П. Развитие творческого мышления студентов в условиях проблемнодеятельностного обучения / И. П. Иванова. Ставрополь, 2002.

6. Кривопишина О.А. Психологія творчості [Текст] / О.А. Кривопишина. - Суми: СумДУ, 2009. - 81 с.

7. Кучерявий I.T. Творчість - основа розвитку потенційних джерел особистості: Навч. посібник. - К., 2000.

8. Лушин П.В. Два виміри принципу «не нашкодь» і кодекс екологічності / П.В.Лушин / / Практична психологія в системі вищої школи: монографія / за ред. Т.В. Бушуєвої, С.О. Ставіцької // Авт. кол. кафедри практичної психології та психотерапії. - К.: НПУ імені М.П. Драгоманова, 2012. с. 38-53.

9. Малімон B.I. Перспективи формування та розвитку студента як творчої особистості / В.I. Малімон // Вища освіта України. 2006. - № 1. - C. 142-145.

10. Мерлин В. Очерк интегрального исследования индивидуальности. - М., 1986. - 256 с.

11. Моляко В.О. Психологічні проблеми творчої діяльності та обдарованості дітей і молоді Наук. записки Інституту психології ім. Г.С. Костюка АПН України Вип. 19: Актуальні поблеми психології. - К., 1999.

12. Моляко В.О. Психологічні проблеми творчої діяльності та обдарованості дітей і молоді Наук. записки Інституту психології ім. Г.С. Костюка АПН України Вип. 19: Актуальні поблеми психології. - К., 1999.

13. Рубинштейн С.Л. Проблемы общей психологии. - М., 1973.

14. Сисоєва С.О. Основи педагогічної творчості вчителя: Навч. посібник. - К., 1994.

15. Фромм Э. Иметь или быть. 2 изд., доп. - М.: Прогресс, 1990. - $180 \mathrm{c}$.

\section{Information about the author: Vynohradova V. Ye.}

Dr (PhD), Associate Professor, Head at the Psychology and Pedagogy Department of the V. I. Vernadsky Taurida National University 33, I. Kudry str., Kyiv, Ukraine 


\section{PSYCHOLOGICAL PECULIARITIES OF REGULATION OF MOTOR ACTIONS OF OLIGIPHRENS WITH THE HELP OF SEMANTIC TASKS}

\section{Zhyljak N. V.}

\section{INTRODUCTION}

The study of the structure of activities has allowed scientists to ascertain that meaning is created as a result of reflection by the subject of the relations existing between him and what its actions are directed as its immediate objective. The motive's attitude to target generates personal meaning, and smalloutline function in this regard motive (Leontiev). At the same time, in the psychomotor action the backbone for it is a semantic task. However, studies on the role of semantic tasks in the management of psychometrika of children oligophrens are mostly absent, and they are studied simultaneously in the context of other problems.

We investigated the effect of semantic tasks on the regulation and efficiency of psychomotor activity of retarded children aged 6-7 years (32 children) with significantly damaged thalamo-pallidar level. First, they performed the semantic task "raise your hand" and then "take off your hat". Mentally deficient children aged 11-12 years (35 children) with significantly damaged pyramido-striatal level first performed a semantic task "draw a circle", and then - "write the letter O". Indicators of motor coordination during the execution of children semantic task was assessed by three experts on a 12-point scale. In the selection of experts to take account of their theoretical framework (master's level special education) and practical preparation (experience of working with children oligophrens not less than 5 years).

An innovative level-structured program of developing skills of regulation of motor actions, which applies all five classes of semantic tasks that operate at all levels of movement construction was developed. Each class of semantic tasks improves coordination on one level, and together they are a kind of "school" of coordination, configuration, and psychomotor actions with objects in normal, and with different intellectual pathologies. 


\section{Psychophysiological mechanisms and the control of motor actions of a human}

Among the various diagram explanations of the control of human behavior prominent place in the history of psychology belongs to the cause of the ring. Perhaps the idea of circularity in the explanation of the mechanisms of control by different processes refers to the so-called "eternal" ideas, which in its general characteristics was mentioned in the ancient Indian epic "Mahabharata". This issue remains relevant for contemporary scholars. Research of features of formation of the ideas of reflexive rings is an important scientific problem in the history of psychology, which started in the works of V. A. Romance, M. G. Yaroshevsky, A. M. Zhdanov and others.

Significant steps towards the development of this problem were made by the French philosopher and naturalist in the first half of the XVII century. The schematic responses of the organism to the influence of factors external and internal environment was a unique explanation of the causal features of control of behavior, mechanisms of its determination. Psychological knowledge has received a powerful impetus for the transition from a purely philosophical to an empirical basis.

At the same time, the English materialist philosopher T. Hobbes created a system of psychology in which sensations and representations (traces of sensation) as the elements of consciousness interact are based on adjacency in space and time. Such mechanistic links will be called "the association" in the future and will contribute to the emergence of associative areas in psychology. Since evaluating the author's false view that mental processes are just phenomenal reflection of brain processes, as well as his theory of mechanistic constraints it is still possible to argue that the proposed mechanisms of functioning of the psyche contain the basis for the development of materialistic deterministic scheme behavior.

A prominent German scientist (philosopher, linguist, historian, mathematician) G. Leibniz, reflecting on the principles of mental reflection, came to the recognition activity of the soul even in sensation. He introduced into scientific use the term "percepta". The allocation of perception and percepts, or primitive presentation of specific content and a clear conscious perception, stated not only the dependence of perception from a combination of factors caused by the experience of the subject, but also meant certain cyclic diagram of operation of these processes. 
Regarding the problem of the reflex ring, we note that the approaches to its understanding in psychophysiological terms are outlined in the theory of vision operation developed by John. Berkeley. This English philosopher explained the visual perception of space from the perspective of the principle of association based on subjective idealism that contributed to the formation of associative psychology.

Cyclic mechanisms of behavior control are holistically viewed in the ideas of reflex rings, formulated by George Dewey. This psychologist and philosopher of Michigan, Chicago and Columbia universities, was convinced that all psychic abilities are tools to solve life's problems. Actually George Dewey's instrumentalism resulted in functionalism, and he can be considered the founder of functional psychology as a distinct phenomenon.

Dewey and his followers believed thet the body is a holistic system and criticized the structuralism of W. Wundt and E. Titcher, who sought to highlight "sensory mosaic" of consciousness. Representatives of functional psychology were convinced that all mental processes and properties are directed to the connection of the organism with the environment, and structural psychology is a kind of concentrated essence introspective interpretation of the psyche, the study of the psyche as a closed in itself consciousness.

Functional psychology, based on the theory of evolution of Darwin, positivist psychology Herbert Spencer, the pragmatic psychology of W. James, is completing a significant amount and content of the period of formation of natural-scientific psychology, and the concept of the reflex ring developed by J. Welles Wilder. Dewey presents the idea of cyclicality on a new, much higher level. V. A. Romenets said: "The idea of the ring, according to Dewey, takes on a significant life of meaning, precisely because the ring is the coordination of members who come together in conflict situations. This conflict is expressed in the temporary disintegration of the adaptive act and the need to recreate the integrity in the interaction of sensory stimuli and motor responses". Also, the scientist stresses that the concept of the Dewey "stimulus" and "response" are different in both the functional phase-coherent mutual mediation or supplement. "The idea of the ring makes it possible to understand how the stimulus is adequately determined, and the answer can be logically and naturally completed. Any behavioral achievement means that the motor response helps in the discovery, invention, and institutionalization of incentive. So. there is the movement of a certain 
level, as the result, the complex of sensations becomes clearer and more objective" 1 .

This is the first in the history of science to describe the principle of feedback in the management of human behavior. Even more so, Dewey applies the idea of a reflex ring to explain the nature of psychic evolution, the analysis of thinking activity, the study of motor systems, the justification of identity consciousness.

The founder of the first laboratory of the experimental research of the psyche in the territory of Ukraine M.M. Lange, the author of the theory of volitional attention (motor theory of active whole subordinate perception), explained the processes of attention and perception, based on the reflex nature of the functional brain units, and described them on the principle of "ring reaction". This substantially enriched the paradigm of the reflex ring in psychology. In particular, this approach allows us to explain the assimilating sense and the integrative image function.

M. Zhdan noted that the work of I. P. Pavlov significantly influenced the development of psychology, particularly in Russia, his doctrine o conditional reflexes was the determining factor for the development of natural-scientific psychology. "However in the conditions of ideological pressure, which was felt by science in the Soviet period, there was an absolutization and dogmatization of Pavlov's doctrine and turned on the forcible imposition of it in psychology and in other fields of study (medicine, pedagogy, linguistics, etc.). The development of the reflex theory of I. P. Pavlov was slowed down"2.

M. A. Bernstein's, P. K. Anokhin's and other scientist's attempts to develop the doctrine of reflexes were administratively prohibited. In particular, the development of schemes of management actions based on the principle of the reflex ring was forbidden.

The first who experimentally demonstrated the idea of the functioning scheme of the reflex ring was an outstanding physiologist, psychologist, biomechanist M.M. Bernstein. Biomechanically examining the management structure of psychomotor action, the author came to the conclusion that the relationship between the effector commands and the actual results of the motions are ambiguous. Experiments have shown that the result of the movements, in addition to effector orders directly impact beyond the individual gravitational, inertial and reaction forces. And this

\footnotetext{
${ }^{1}$ Роменець В.А. Історія психології ХІХ початку XX століття / В.А. Роменець. - К. : Вища школа, 1995. - C. 256.

2 Жиляк Н.В. Психологічні особливості регуляції моторних дій за допомогою смислових завдань: монографія / Н.В. Жиляк. - Кам’янець-Подільський : Медобори-2006, 2015. - 150 с.
} 
with the extreme complexity of the structure of the musculoskeletal system (more than 200 bones and over 600 muscles, more than 100 degrees of freedom of motion in the joints) that knocks the implementation of the motor function of a person of certain trajectories and hinders the achievement of goals. Therefore, the repetition of even simple actions is not their exact copy. It is a repetition without repetition.

Therefore, under these conditions, once sent to the effector muscles orders can't fully determine the kinematic and dynamic characteristics of the action. The required correction of movement based on the detection of differences between the forming target of the action and its actual parameters.

Biomechanical measurements experimentally confirmed the idea of "the regulation of movements with a feeling of" using the feedback scheme of the ring. This is one of the most important principles of all types of control. The correct relationship, in particular, muscle tension and effective movements require the continuous introduction of corrective signals to the working muscle synergies. Corrective signals are generated, as already noted, on the basis of comparison of planned and actually made movement.

Exploring the neurophysiological mechanisms of higher nervous activity, the author of the theory of functional systems and one of the founders of neurocybernetics P. K. Anokhin assigns a cyclical control reflex the leading role. According to the scientist, without a recurrence the control is impossible. Anokhin emphasized that all functional systems, mechanical or living, which are focused to give useful effect, and therefore, they must have a cyclic character. In other words, functional systems can't exist if they do not receive reverse signaling about the degree of usefulness of the effect.

P. K. Anokhin justified the existence of "accentor of actions" - the device intended for the perception of the expected outcomes of the action. It is important that accentor of the action is formed earlier than the reflex. Its main purpose is to take in all stimuli that arise as the operation in forms of reverse differentiation and its result, and conducts a comparison of this synthesis with predictable results of the action. When the planned and actual movements are coincidence, the entire cyclical process completes, but their "difference" is a series of new preferential adjustments aimed at achieving a reflex response adequate to the nature of the acceptor of the action.

In a complex system of afferentation, the author had identified basically three types: a) starting aperently submitted to the action of the 
conditioned stimulus; b)situational afferentation, represented by a set of stimuli that creates a certain dominant state of the living organism; c) the opposite afferentation apparently associated with proprioceptive sensations needed to control the activity of the muscle periphery. Anokhin's special attention was paid to the synthesis of all the afferent signals of external and internal sensations. According to the author, any reflex action could not be formed in the effector apparatus until the synthesis of all reference information that represents the organism at a particular time is finished. Even more, the exclusion of at least one of the afferent systems immediately destroys the reflex.

Exploring the management features of arbitrary action by the scheme of the ring (the brain is centrifugal nerves - muscles - of proprioception nerves), towards the center, the brain, the area where direct communication is the way the brain is a muscle, and feedback - muscle, brain, M. O. Bernstein's student L.V. Chhaidze proposed to divide this ring into external and internal. External ring, according to the author, includes a direct connection (brain - muscle) and outer arc feedback (visual, auditory, olfactory, tactile, and other receptors that have semantic apparently, the brain). The inner ring includes a direct connection (brain muscle) and the inner arc feedback session (proprioception not directly related to human consciousness, the brain). So, in dola-ring (two ring) scheme proposed by Chaze, the plot of a direct connection is common for the inner and outer rings.

L. V. Chhaidze proposed such a control scheme of arbitrary motor actions of a human because the inner and outer ring play a different role in the control of the psychomotor activity of the subject. The outer ring controls the semantic side of the motor act and the internal work of muscular synergies. Such functional separation proves clinical trials. The regeneration pathways of the spinal cord loss of movement coordination (meaning the action is stored) and the relatively high damage of brain areas observed violations of the meaning of actions(coordination is maintained). For example, animals with distant higher parts of the brain walk well but do not notice the food. It can be stated that the function of the inner ring is the provision of biomechanically appropriate movements by prolonged exercise, as a function of the external - perform semantic tasks by knowledge of the fine structure of the semantic structure of the action.

At the same time, Chhaidze notes that this distribution of functions is not absolute and identical in all cases. In particular, when performing 
unfamiliar work in the lower divisions of the Central nervous system does not yet have the relevant work program of muscle synergies and higher departments have to monitor the semantic structure and motor structure. It is clear that the higher departments are not designed to manage energetic, specific details and actions are biomechanically inefficient (using external feedback). The author stresses that if one of the action control rings does not fully cope with their responsibilities, then the second (partial) assumes his functions, however, the engine act, under such conditions, always drop one or another of its components. These facts are confirmed in the studies of A. I. Shinkaruk.

Dola control scheme movements by L.V. Chhaidze, was improved by E.G. Malkhazov, actually offering two schemes: a scheme of forming a mental image of the running motion (action, operation) and the scheme of the psychophysiological mechanisms that provide the construction, organization, and control of motor activity. In these schemes, the author revealed the relationship between psychological and physiological control mechanisms of psychomotor actions. As for the distribution of functions between the two rings, the author stresses that the "full control becomes possible after the lower divisions to form respective modules and provide internal feedback. Only under these conditions, it becomes possible to perform complex motor actions where the monitoring of the semantic structure is an outer control ring, and the inner provides the finest synergistic implementation details of this movement" ${ }^{3}$.

Analyzing the cyclical behavior management, V. A. Romainets writes: "However, the idea of the ring must be completed. Then the "ring" becomes a "spiral", because the feedback is not a repetition of content, but the getting of new" [6, p.257 $]^{4}$. We agree with this, and use it to confirm the control of psychomotor actions: "It is known that a motor-sensory way of operation and domain-intellectual thinking, that is, the same mental model of the action that regulates and supervises its implementation, inevitably presupposes the existence of search and trial selection in the process of repeating actions. Successful guidelines that are justified, the methods of regulation and the ways of combining movements into a complete action is selected and fixed" ${ }^{5}$.

\footnotetext{
3 Малхазов О.Р. Психологія та психофізіологія управління руховою діяльністю: монографія / О.Р. Малхазов. - К. : Свролінія, 2002. - С. 95-96.

${ }^{4}$ Роменець В.А. Історія психології XIX початку XX століття / В.А.Роменець. - К. : Вища школа, 1995. - C. 257.

${ }^{5}$ Шинкарюк А.І. Психологія діяльності: навчальний посібник / А.І. Шинкарюк, В.А. Шинкарюк, Р.T. Сімко; за заг. ред. А.І. Шинкарюка. - Кам’янець-Подільський: Оіюм, 2018. - С. 21.
} 
Consequently, feedback is not a repetition of content, and acquires new methods of performing movements, changing patterns of the touch control, changing patterns of central regulation.

There are two levels of programming of movements. First, a part of the outer ring and ensures the implementation of the tasks associated with the semantic structure of motion. The second determines the sequence of movements in detail (the order of inclusion of muscle synergies) and is included in the inner ring control. A.G. Malkhazov writes that "The presence of pyramidal and extrapyramidal tracts gives the ability of the Central nervous system to control movements with both rings, giving preference in the management of one of them, depending on the degree of mastering of this movement by the individual. The mechanism that sets and the mechanism that programs do not have specific "residence" in certain centers of the brain. Depending on the objectives, level of automation of the motion, con-rol is completed by different subordinate levels of the Central nervous system" ${ }^{6}$.

Proving the existence of sets of movement negrams, M.A. Bernstein leads the existence of motor skills and automatic movements. Mechanisms of functioning of movement negrams as multi-step processes are elaborated by O.R. Malhasov.

The conditional reflex, as ontogenetic engram, according to A.R. Malkhazov is a highly integrated phenomenon, in the establishment and operation of which various cortical and subcortical structures of the brain are involved, which also are involved in this process from different functional and temporal contributions.

Considering the problem of the functioning of functional systems from the standpoint of psychophysiology and psychology, the author argues that "psychophysiological features of activity of functional systems and levels of building and managing movements, selected by M.O. Bernstein, L.V. Chhaidze, D.D.Donskyi, P. K. Anohin, do not fundamentally differ from each other" ${ }^{7}$.

Specific features of managing human behavior are influenced by his age, individually-typological properties and non-normative development mental retardation.

Therefore, one of the major schemes of the relationship between motor skills and psyche is a reflexive ring. Understanding of the cyclicality in explaining the mechanisms of control of movements was developing and specifying in the history of psychology and allowed

\footnotetext{
${ }^{6}$ Малхазов О.Р. Психологія та психофізіологія управління руховою діяльністю: монографія / О.Р. Малхазов. - К. : Свролінія, 2002. - С. 96.

Там само. - C. 92.
} 
identifying how adequately the stimulus is determined and response acquires its logical conclusion. The principle of feedback in the control of motor action has allowed us to understand how sensations become more expressive and objective. Recognition of the functioning of the brain units based on the principle of "circular reaction," explained the assimilative function of integrating sensations and images.

Experimental evidence of ambiguity between the effector commands and the actual results of the movement substantiate the need for their correction. Important steps in the study of mechanisms of control of arbitrary motor actions of a human were proposed two-ring diagram of the formation of a mental image perform the movement, the scheme of psychophysiological mechanisms that provide the construction, organization, and control of motor activity. The idea of cyclical behavior management has acquired new meaning when the "ring" became "spiral", as feedback is a mechanism of finding a new and not a repetition of content.

\section{Features of the structure of the program of development skills of regulation of motor actions in a semantic task}

Physical training of the younger generation is one of the urgent problems of the development and strengthening of the state, to establish its independence. Human health is a decisive factor that determines the fate of future reforms. At the same time, the evidence of these statements contrasts with the real low level of physical fitness and health of school children and university students. Under such conditions, the physical education of the younger generation can be considered as the most efficient and cost-effective way of disease prevention, improve mental and physical health, employability of workers. Contribute to the psychophysical development of young people has its psychomotor training, which significantly enhances the professional reliability of a specialist in modern conditions when the human factor is the cause of the vast majority of accidents and disasters. The methodological basis of psychomotor training of student's youth can be the principle of unity of consciousness and activity, are well described in modern literature, according to which the opposite of objective motor and subjective psyche is not absolute. This contrast is eliminated by functional transition of noticed phenomena that prove the organic unity between the motor skills and mind, material, and ideal. A. I. Shinkaruk emphasizes that the psyche is objective in functional parts of the body as the temporary combination 
of forces that can carry out a specific achievement and, the author notes that biodynamic fabric living movement at the same time becomes its sensual tissue in them ${ }^{8}$.

Functional organs are complex systems and behavioral achievements that they provide include both psychological and physiological processes, which is particularly important for the study of psychomotor. In particular, the functional approach to the study of psychomotor is not possible without taking into account the system's levels of movement construction, studied in detail by M. A. Bernstein. However, it requires further development of the problem of the development of skills of regulation of motor actions in a semantic task.

The lowest level of the building movements that has a functional autonomy is a level A - paleokinetic regulation (rubrospinal). It already contains morphological derivations, which can send certain effector commands from the brain to the muscles, and specific receptor derivations, which perceive reference information. First of all, synthetic sensory field of rubrospinal level can determine the body's position in space relative to the earth's gravity and the relative arrangement of the parts of the body, getting proprioceptors apparently the strength and direction of pressure on the muscle tissue (mainly deep) and information about the magnitude and direction of muscle stress. Central nervous coordination level of paleokinetic regulation A is partially located in the spinal cord and partly in the nerve centers (red nucleus, and others) of the lowest divisions of the cerebellum. This level maintains muscle tone and the excitability of the muscle groups needed to execute the command pulses from the layers above.

Rubrospinal level of movement construction is a morpho-functional basis of the decision of semantic task of motor actions according to the adoption and preservation of kinematic postures of the body, it controls muscle tone of the trunk and neck. The leading level of paleokinetic regulation is also in the arbitrary motions rhythmic vibration and involuntary shake from fear or cold, and also in jerking.

Analyzing the conditions when level A is leading for saving poses, M. O. Bernstein notes that this usually occurs in one of the phases of the chain of complex motor act, and cites the examples of the phase of flight of the long or height jump, the ski jump, a starting jump into the water, etc. ${ }^{9}$

\footnotetext{
${ }^{8}$ Шинкарюк А.І. Психологія діяльності: навчальний посібник / А.І. Шинкарюк, В.А. Шинкарюк, Р.Т. Сімко; за заг. ред. А.І. Шинкарюка. - Кам'янець-Подільський: Оіюм, 2018. - С. 85.

${ }_{9}^{9}$ Бернштейн Н.А. Физиология движений и активность / Н.А. Бернштейн; под. ред. О.Г. Газенко, изд. подгот. И.М. Фейгенберг. - М. : Наука, 1990. - С. 59-60.
} 
For all other motor actions and, accordingly, the semantic tasks, which they deal with, the level of paleokinetic regulation is the background. The function of the level A in their implementation consists in the regulation of tone and the excitability of muscles, which, as we know, are not determined directly by consciousness.

Consequently, functional autonomy of rubrospinal level should be treated dialectically ${ }^{10,11}$. At the same time the necessity of getting psychomotor activity experience proprioceptive regulation of the positions in space of the execution of motor actions by subjects does not cause doubts. Awareness of body position and its separate parts in space and the retention of postures, undoubtedly, are separate "class" semantic tasks of motor actions.

To develop the coordination capabilities of rubrospinal level by using various physical exercises for the reproduction and differentiation of various kinematic poses. These exercises should be presented in the program of the development of skills of regulation of motor actions. To determine the psychomotor capacity of the subject at the level of paleokinetic regulation is appropriate by using a variety of tests on the preservation of static equilibrium.

Thalamo-pallidar level of synergies is located above rubrospinal level A or the level of friendly movements and standard stamps B. Proprioceptoral and tangoceptoral apperentice of the level allows to obtain information about the dynamics of movements in the body schema, in particular, to assess the relative positions of the parts of the body, the value of the angle between biochains in the joints, the speed, and direction of their changes. M. O. Bernstein emphasizes that the thalamo-pallidar system (the major subcortical nuclei deep brain regions: the optic protuberances, pale bodies, and some others) secures three important focal qualities. First, the level of synergies can combine the work of many dozens of muscles to coordinate the movements of all links in the schema body. Second, the level of friendly is able to combine movements in time to coordinate the sequence and alternation of movements of all extremities with millisecond precision. Thirdly, due to the fact that the movements of the thalamo-pallidar level are performed without regard to the world, they tend to be repetitive, to stamps ${ }^{12}$.

\footnotetext{
${ }^{10}$ Шинкарюк А.І. Рівні побудови рухів і смислова структура дії / А.І. Шинкарюк. - Кам'янецьПодільський: ФОП Сисин О.В., 2008. - 200 с.

${ }^{11}$ Шинкарюк А.І. Психологія діяльності: навчальний посібник / А.І. Шинкарюк, В.А. Шинкарюк, Р.Т. Сімко; за заг. ред. А.І. Шинкарюка. - Кам’янець-Подільський: Оіюм, 2018. - 208 с.

12 Бернштейн Н.А. Физиология движений и активность / Н.А. Бернштейн; под. ред. О.Г. Газенко, изд. подгот. И.М. Фейгенберг. - М. : Наука, 1990. - С. 67-69.
} 
Having a perfect afferentation on a dynamic picture of the movements in the scheme of the body and rich coordination capabilities, level B as a leader acts only in the movements expressive facial expressions, pantomime, and plastics. The author of the theory of the levels of movement construction emphasizes that they are not symbolic, but directly emotional movements. At the same time, he writes that "Almost beyond the level that is characterized many of the movements in gymnastics are occurred: trunk bending, flexing, tilting body, a variety of plastic and rhythmic movements"13.

Thalamo-pallidar level ensures the stability of motions in a dynamic force field of action that involves the use of inertial and reactive forces in solving motor tasks. At the same time, it should be noted that providing a certain stereotype of human movement, the level of friendly movements and standard types is not stereotypical, and that allows it to fit the movement in the dynamic conditions. "The functional possibilities of level B can be defined by dynamic tremor, dynamic balance, fidelity (without visual control) spatial and temporal characteristics of the movements" ${ }^{14}$.

Thus, thalamo-pallidar level has its afferent and efferent synthesis, which distinguishes it from all other kinetic systems of the human body and ensures the implementation of a particular semantic class of problems for which this level is leading.

To improve the coordination capabilities of thalamo-pallidar level by using various physical exercises of reproduction, and differentiation to measure the relative positions of the parts of the body, the magnitude of angles in the joints, the direction and speed of changes need to be presented in the program development skills of regulation of motor actions. To determine the psychomotor capacity of the subject at the level of friendly movements and standard dies appropriate using a variety of tests on dynamic equilibrium and the fidelity of the spatial, temporal and power characteristics of movements without visual control.

Pyramido-striatal level of spatial fields $C$ morphologically is located between the oldest and the newest formations of the brain and is divided into two sublayers. The lower forms the core of the "striped body" striatal sublevel of the extrapyramidal system, and the higher giantpyramid field of the cerebral cortex, pyramid sub-level cortical

\footnotetext{
13 Бернштейн Н.А. Физиология движений и активность / Н.А. Бернштейн; под. ред. О.Г. Газенко, изд. подгот. И.М. Фейгенберг. - М. : Наука, 1990. - С. 71.

${ }^{14}$ Шинкарюк А.І. Рівні побудови рухів і смислова структура дії / А.І. Шинкарюк. - Кам'янецьПодільський: ФОП Сисин О.В., 2008. - С. 10.
} 
system. Accordingly, the level of spatial fields gets afferentiation on balance, changes in the joints and muscles with the lower structures of the human brain and information from visual analyzers, which provides the functionality to control involuntary muscular groups and arbitrary complex actions.

The level of spatial fields is proprietory, has tango-receptor and teleceptor afferentation that allows it to coordinate movement with external space that is "tied" to their environment. M. A. Bernstein writes that "the movements of the spatial fields are first clearly identified target, they are from somewhere, where and why. These movements are extrovertive facing the outside world and to a lesser extent than movements in the level of synergies, introvertive. Movements of the level $\mathrm{C}$ carry, push, pull, take, tear, throw. Movement in spatial fields are always transportable; if their appearance is sometimes cyclical when necessary due to the construction of our limbs (walking, running), because of the semantic structure these movements as well as space in which they occur are non-periodic" ${ }^{15}$.

Pyramido-striatal level ensures the achievement of the target in space with enormous flexibility and variability of the trajectories of biochains of the body. The level of spatial fields is the lead in all movements of the body as a whole and its parts (locomotion, throwing, punching). The psychomotor ability level can be determined by the indicators of the accuracy of various movements, where the level A is leading. A. I. Shinkaruk writes: "It can be argued that oral-search activity at this level provides a significant opportunity to generate a "cognitive hypotheses". If you extend this provision to all functions of the psyche tonic-inductive, regulatory-practical, and imaginative, and other functions, we can assume that oral research activity allows to generate hypotheses from all sides of the act of reflection" ${ }^{16}$.

To develop the coordination capabilities of the pyramido-striatal level by using a variety of physical exercises to target precise movements in space. For example, throwing objects at the target, the execution moves to bypass obstacles and so on. The determination of the psychomotor capacity of the subject at the level of the spatial field-expedient with a variety of playback tests, measuring and differentiating the spatial accuracy of movements should be included in the appropriate program.

\footnotetext{
${ }^{15}$ Бернштейн Н.А. Физиология движений и активность / Н.А.Бернштейн; под. ред. О.Г. Газенко, изд. подгот. И.М. Фейгенберг. - М. : Наука, 1990. - С. 83-84.

${ }^{16}$ Шинкарюк А.І. Психологія діяльності: навчальний посібник / А.І. Шинкарюк, В.А. Шинкарюк, Р.Т. Сімко; за заг. ред. А.І. Шинкарюка. - Кам’янець-Подільський: Оіюм, 2018. - С. 12.
} 
For example the accuracy of the jump (or triple jump) from place to a certain reference distance.

Over pyramido-striatal level is parietal-premotor level of subject actions or semantic chains D. Morphologically it is the highest divisions of the cerebral cortex. Getting teleceptor information not only about the size of the object, but mainly on the ratio of its individual parts as a whole (topological quality), this level is responsible for the semantic decision task of the action items and only a human has it. M.A. Bernstein writes: "The leading motive at the level of action is actually not a subject by itself, as a geometric form as something with a certain weight, texture, etc... and the semantic side of the action with the object still appears whether the object in this action object or even as its instrument" ${ }^{17}$.

Level D allows the subject to carry out actions with the objects of human culture on the basis of understanding their functions and topological qualities. This allows indirectly influence the environment (affect some items on the other) implementing tooling function in human work. In the process of activity management level $\mathrm{D}$ gets the importance of acquiring functional asymmetry of brain hemispheres and the possibility of the formation of appropriate skills. All the action items parietal-premotor level is the leading and only through acts of speech and writing it is the background, acting as a "higher automaticity".

Describing the parietal-premotor level, the author of the theory of movement construction writes that "the movement in the level of substantive actions constitutes acts of meaning, i.e., it is not so much movement, how many elementary actions, defined by the sense of the task. To put on and fasten coat, lubricate ski ointment, to drive the soccer ball into the opponent's net, cultural to eat the egg... - here is the simple object action; and each of them is a set of movements that, in general, solve a particular semantic problem". And further: "... not all high intelligent engine acts can find a place in this level. In the level of actions coordination does not fall, for example, symbolic or conditional semantic actions, which primarily include not technically executive, but leading in semantic coordination of speech and writing..."18.

Therefore, you can definitely say that N. And.Bernstein points to the complexity of the meaning of actions in a hierarchy of levels of building movements: each higher level of movement construction is leading to

\footnotetext{
${ }^{17}$ Бернштейн Н.А. Физиология движений и активность / Н.А. Бернштейн; под. ред. О.Г. Газенко, изд. подгот. И.М. Фейгенберг. - М. : Наука, 1990. - С. 120.

${ }^{i 8}$ там само. - C. 144.
} 
more complex actions than the lower one. In other words, higher levels are able to solve more complex semantic tasks than lower.

To improve the coordination capabilities of parietal-premotor level, you can use a variety of physical actions with objects, changing both the geometric and topological features of these items. These semantic tasks should be included in the program development skills of regulation of motor actions. To determine the psychomotor capacity of the subject at the level of substantive actions, or semantic chains by appropriate using of a variety of tests on the effectiveness of the implementation of the action with items of human culture, particularly important are the indicators of fine motor skills.

Over parietal-premotor level, as it can be seen from the following, is the highest cortical level E-level of symbolic (verbal and writing) or the symbolic meaning of actions. Morphologically it is formed by the highast layers of the cerebral cortex, which probably can be divided into different groups E. Describing this level A. I. Shinkaruk writes: "As a result of the evolutionary process corticalis nerve functions, level E dominates all the previous levels. Therefore, the functionality of this level is the highest that is in oral activity as in the semantic characteristics of a speech, and respective motor components, as well as the impact of speech is for all motor actions regardless of what level of construction of movements in their regulation is the leading"19.

To develop the coordination capacity of higher cortical levels of movement construction you can use the action of writing with the help of different devices and on different surfaces, which must be submitted to the appropriate program. To determine the psychomotor capacity of the subject of the level E should be done by using a variety of tests on the effectiveness of the writing. For example the definition of indicators of the error and the time of coordination of writing between wavy lines.

Model of development of skills of regulation of motor actions with the use of semantic tasks is presented in pic. 1.

In modern psychology under psychomotor task the external or imaginary pattern of movements that the subject should reproduce by motor manipulation is understand. A motor task can also be understood as a verbalized instruction that the subject should do in a certain situation by motor activity. And neck, and a verbal description of motor tasks reflects the meaning of motor actions to be performed, and in this way

\footnotetext{
19 Шинкарюк А.І. Рівні побудови рухів і смислова структура дії / А.І. Шинкарюк. - Кам’янецьПодільський: ФОП Сисин О.В., 2008. - 200 с.
} 
they are primarily a semantic task of the subject concerning the future of motor activity.

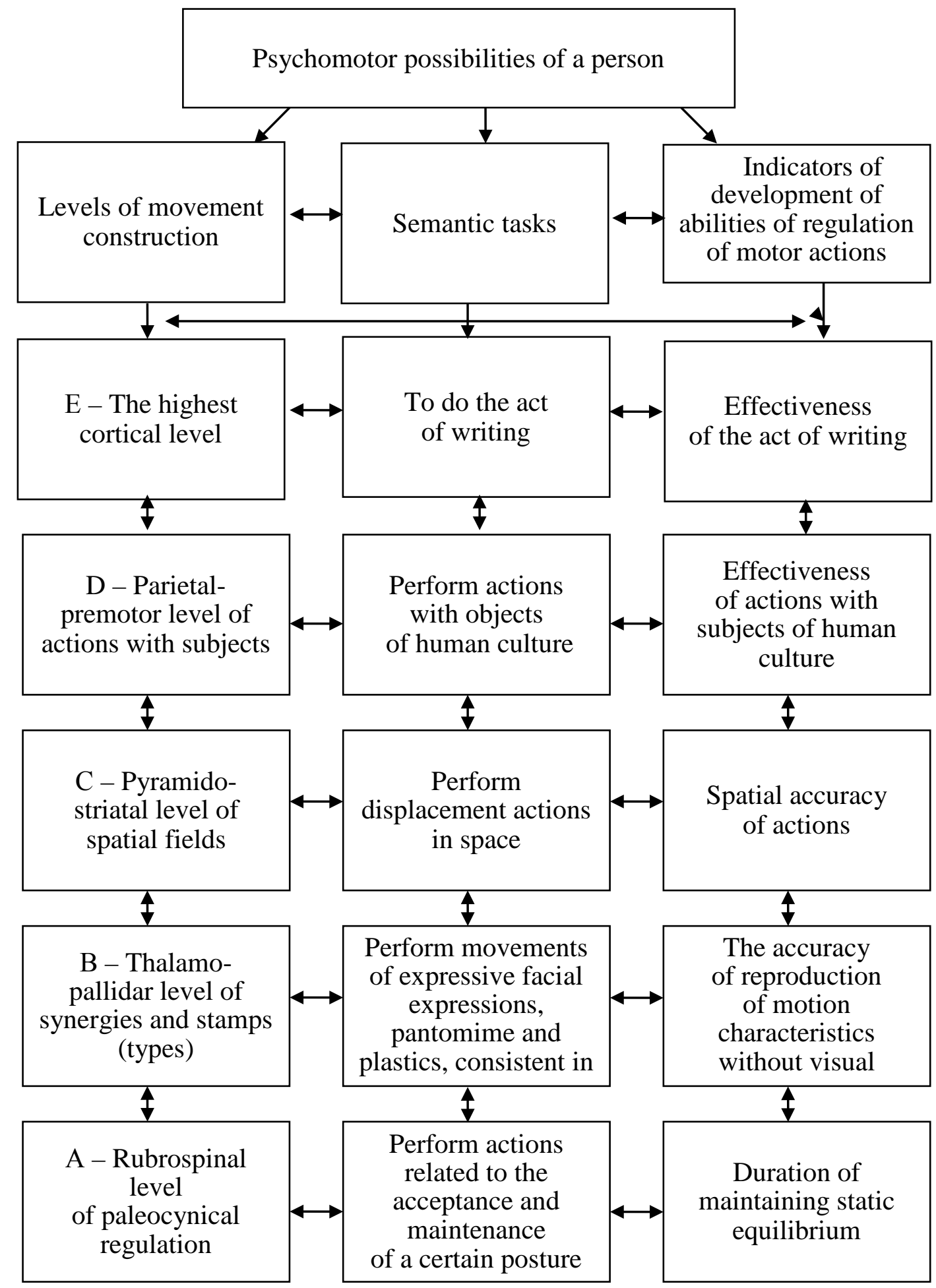

\section{Pic. 1. Model of development of the skills of regulation of motor activities of institutions with the help of semantic tasks}


Image-purpose of the future motor activity is a great idea of the ending result. Psychological regularities and mechanisms of formation of the image of target disclosed in such terms as "setup", "advanced reflection", "advanced setup", "model of required future", "extrapolation", "the acceptor of action results" and many others. For them, the construction of the image-purpose are possible if you have an experience with the patterns of the past and the possibility of the future.

Synthesis of the available information of the person provides an existing conceptual model that decodes all the afferent signals from the system analyzers in a particular moment of execution of motor actions and updates the information stored in the memory and are necessary for the solution of this motor problem. So, a conceptual model is a mental picture of the process of control of movements and modalities for their implementation.

Misalignment between the image-task and conceptual model overcomes the operational image. It is a conceptual model in action. As a perfect reflection of the implementation of the operational image it is quite dynamic. It, on one hand, is constantly changing with the change of movements, and on the another -affects change of movements itself.

In the process of repetition of motor actions specified systems the sensory syntheses, sets the leading level of the building movements specified engine composition and its images are its reflection. It switches the coordination of the correction motor act on the most relevant afferent level. It is important to emphasize that the process of automation of the motor action is accompanied by a reduction of the content of images, movements and situations of their implementation. Remain the most significant landmarks, important for the solution of a motor task, realize their meaning.

So, the semantic task, formulated verbally, as the core of a motor task, can almost completely match or be a part of it. In the initial stages of mastering the action they are almost identical in terms of content, since the subject has no experience of their differentiation. In the process of skill formation its motor, sensory and central components differ more and more, gain a new conscious content, its relevant components are specified. In the future, there is a collapsing of information again and the focus of the subject remains only the most important components, which are semantic task-specific psychomotor actions. To understand a motor task is easier than the nucleus - the semantic task. To understand the semantic task means in practice to 
find a way of solving motor tasks. During the process of execution of motor actions the subject is trying to find its meaning is relatively biomechanically feasible trajectories, accents, muscular effort, rhythm combining the movements in action, etc. With independent search of the meaning of this action it takes a lot of time, and it is not always possible to find. In terms of pedagogical impact and work of the student under the teacher's guidance on the implementation of semantic tasks, the process is optimized.

Motor tasks, especially verbally semantic tasks affect the composition of motor actions, which are understood as the set of motor operations performed in a particular spatial-temporal mode in accordance with the content of motor tasks and available external and internal ways of its decision.

M. A. Bernstein noted that the engine part is a function of the task and its execution. Its content is determined by the structural features of the locomotor apparatus: the kinematic chains of the moving parts of the body with their numerous degrees of freedom of motion in the joints (passive part) and the muscular system, the nervous centers, afferent and efferent paths (active part). Undoubtedly, the composition of motor actions depends on the conditions of its implementation, and the objects with which it is performed. At the same time, the motor part of the action before its beginning cannot be fully determined. Its full manifestation is in the process of practical implementation of the actions of a subject when implementing a correction system that corrects for differences between the image target and the actual movements at different levels of the coordination structure. So, for the development of skills to make an effective correction in the process of regulation of movements is advisable to create optimum variable conditions of implementation of the motor function of the subject and aiming movements (the assimilation of the sensory metric standards).

Analyzing the theory of levels of construction of movements by N. A. Bernstein E.M. Surkov stresses that it gives reason to two important conclusions: control of motor actions are carried out at different levels of the nervous system, levels of construction of movements interact on the principle of the dynamic of subordination. Motor tasks, semantic tasks are the motor part of the action, afferent and efferent synthesis (specific for each level), master level.

So, individual features of the development of the skills of regulation of motor actions are predetermined first of all by the originality of their 
coordination capacity at different levels of construction of movements. Thus, the program of development of the psychomotor capabilities of a subject must contain means of influencing all levels of movement construction. This level-structured program of developing skills of regulation of motor actions should include a system of semantic tasks to do that will lead to the use of all levels of movement construction. So, it is advisable to apply a system of semantic tasks, which are solved at all levels of movement construction, in variable conditions, which can improve the ability of regulation of motor actions of children with mental retardation.

\section{Features of the implementation of the semantic task to perform the motor actions that are leading to different levels of movement construction of children oligophrens}

Conscious regulation of the subject motor action, which is implemented through specific semantic tasks, has always been one of the central problems of psychological science. A. G. Luria highlights in the motor actions their semantic structure and motor structure. Semantic structure characterizes both the content of the tasks of the action, its meaning, and engine structure as a way of solving the problem, work of specific muscle synergies. The fact that any motor actions are both mental and motor components, is confirmed by.G. Ananiev, Is.P.Ilyin, V. V. Klimenko, and others.

M. O. Bernstein found that the motor components of action are determined and sent to the semantic task. He identified five levels of movement construction and, accordingly, five classes of semantic tasks. Levels of construction of movements interact with each other according to the principle of dynamic of subordination and violation some of them can be compensated.

In Particular, O. M. Leontiev, A.V. Zaporozhets, restored movements after injury using occupational therapy, systematization of violations of psychomotor mentally retarded children in the structure of the levels of construction of movements studied by M. P. Wiseman.

The relationship between semantic structure and composition of motor actions is also confirmed in modern studies of O. G. Malkhazova and others.

But still, the question remains open how the different semantic tasks according to the regulation of motor actions can be used for rehabilitation, psychomotor disorders of mentally retarded children. 
At the stage of ascertaining the experimenting, we organized a group of mentally retarded children 6-7 years (32 children), with a noticeably damaged thalamo-pallidar level of movement construction level or level of coordinate movements and standard types. The effectiveness of psychomotor activity (coordination of movements) was studied in all studied students when the first semantic tasks "raise your hand" (which is the leading level B), and then semantic tasks "take off your hat" (for which the leading is the level D - parietal-premotor or level of actions with objects and semantic chains).

On the second sub-phase a group of mentally retarded children 11-12 years of age(35 children)was created, with a noticeably damaged pyramido-striatal level of construction of movements or spatial fields. The group was studied on the subject of coordination of movements (efficiency psychomotor activity) in the performance of their first meaningful task "draw a circle" (for which lead is pyramido-striatal level or spatial fields), and then the semantic task "write the letter O" (which is the leading level $\mathrm{E}$ - the highest or the cortical level of symbolic coordination of speech and writing).

Indicators of motor coordination for children semantic tasks were assessed by three experts on a 12-point scale (pic. 1. and pic. 2.). In the selection of experts to take account of their theoretical framework (master's degree of special education) and practical preparation (experience of working with children oligophrens at least five years). The proper performance of the semantic task was demonstrated and explained.

The execution of mentally retarded children 6-7 years meaning task "raise your hand" was estimated to $4.78 \pm 0.17$ points. The low level of efficiency of performance of psychomotor action is primarily due to the fact that this group consisted of children with violations of sight tubercles, pale bodies and other major subcortical nuclei deep departments of a brain. According to morphological damage they observed a deterioration of the processing of proprioreceptoral and tangoceptoral information about relative position of body parts, angles of joints and the direction and speed of their changes. General dynamic picture of the movements of the whole body and its parts is incomplete.

With the damage of thalamo-pallidar system the coherence of the muscle synergies of dozens of muscles in space and time is noted, and during the repetition of movements. Performing semantic tasks "raise your hand" surveyed the first group was characterized by a lack of plasticity and rhythmicity of movements, ineffective involvement of inertial forces 
to its solution. The movements investigated in the force field of the action are unstable.

The second semantic task ("take off your hat") is much more complicated than the first. Leading in his performance is the parientopremotor level of construction of movements or the level of actions with objects and semantic chains.

The execution of the task "cap off" by children oligophrens 6-7 years was assessed $5.31 \pm 0,15$ points. Therefore, an arithmetic average of the studied differ by 0.53 points, which is statistically reliable indicator, $\rho<0,05$ according to efficiency of the execution of semantic tasks.

Table 1

The results of empirical research skills of regulation of motor actions of (in marks) mentally retarded children in the process of implementing various semantic tasks

\begin{tabular}{|c|c|c|}
\hline The semantic task & Leading levels & $\begin{array}{c}\text { The average results } \\
\text { of the groups }(\mathbf{M} \pm \mathbf{m}) \text { ) }\end{array}$ \\
\hline & The studied pupils of 11-12 years \\
\hline Write the letter O & The Highest cortical, E & $6,18 \pm 0,13$ \\
\hline Draw a circle & Pyramido-striatal , C & $5,57 \pm 0,16$ \\
\hline & The studied pupils of 6-7 years \\
\hline Take the cap off & Parietal-premotor , D & $5,31 \pm 0,15$ \\
\hline Raise your hand & Thalamo-pallidar, B & $4,78 \pm 0,17$ \\
\hline
\end{tabular}

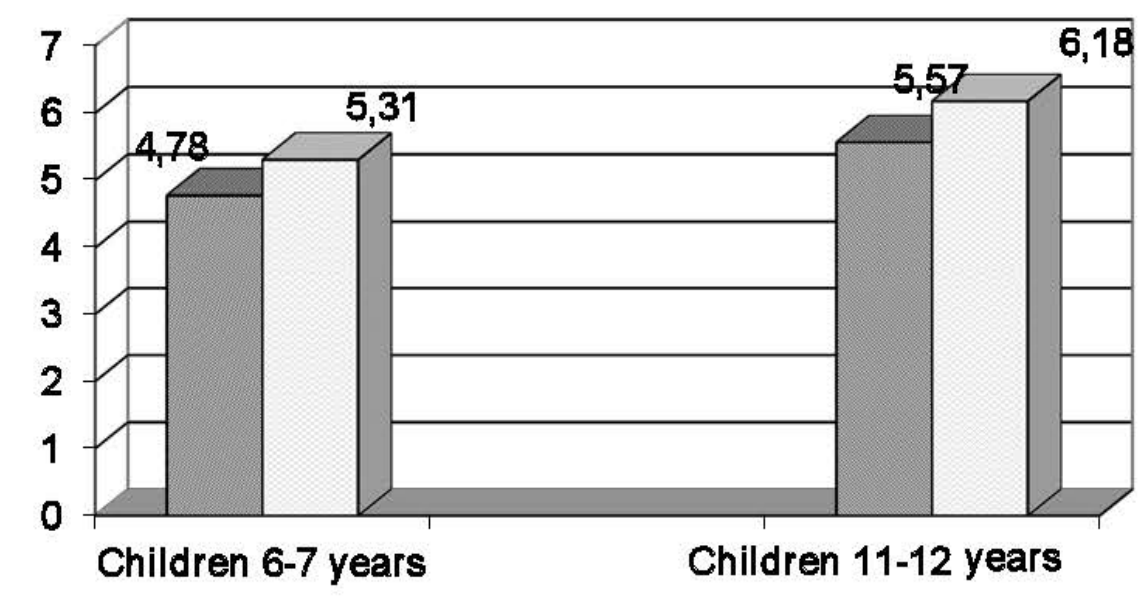

घEasier task 口More complicated task

Pic. 2. The performance skills of regulation of motor actions (in points) mentally retarded children in the process of implementing of various semantic tasks 
Taking into account the variety of damage of the Central nervous system in the examined children with persistent disorders of the intellect, the higher divisions of the cerebral cortex are better preserved than the major subcortical nuclei. Level $\mathrm{D}$ with its telereceptoral afferentation allows to perform actions with objects, reflecting their topological, but not metric qualities. At the same time, observation convinced that the solution of the investigated semantic specification has the value of the functional asymmetry of the brain, and education skills.

Comparison of efficiency of psychomotor activity in the process of solving the semantic tasks by mentally retarded children of preschool age showed that the phenomenological side of the outer movements is an indicator of the processes in the Central nervous system and higher mental functions. Semantic task determines which levels of the nervous system are leading in the motion control, which afferentation for them would be leading, how the motor action will change.

On the second sub-phase of the fourth stage of ascertaining experiment of the study mentally deficient children aged 11-12 years implemented the first semantic task "draw a circle", which was estimated $5.57 \pm 0.16$ points. Leading in the management of this action is the pyramido-striatal level of spatial fields C. Low assessment of coordination of movements of the subject in the drawing of the circle is due to the available morpho-functional disorders in subcortical and cortical structures of the brain. The level $\mathrm{C}$ is between the newest and the oldest structures of the brain and unites grantopera field cortex (pyramid sublevel cortical system) and subcortical nucleus - "striped body" (striatal sublevel of the extrapyramidal system). Consequently, the level of the spatial fields receives information from visual analyzers (higher sublevel), as well as information about the dynamics of motion in joints and muscle status (lower sublevel). At the same time, violation of the level destroys control arbitrary complex action and phylogenetically ancient coordinative and involuntary movements.

Children with mental retardation with violations of pyramido-striatal level primarily target precision of movement is destroying. While drawing a circle, they usually are difficult to start and complete, transportable movements are inaccurate, that is, inconsistent with the space in which they are implemented, and the movements lose variability and flexibility. Error in "bondage" to the environment are the basic signs of violations of spatial fields C. Analyzing the work of sublevels, M. O. Bernstein notes that " on the upper sublevel of $\mathrm{C} 2$, the same adaptability to the external space becomes thinner and more special, acquiring more target or final in 
nature, and turns into the projection of the motion on its endpoint in the external space with the installation of precision or accuracy. This sublevel is largely indifferent to the trajectories, the method, and manner of performing the intermediate stages of movement, fully corrective shifting the emphasis in the final paragraph, in which, like in focus, should gather all possible... the trajectory of motion".

At the same sub-phase surveyed mentally deficient children aged 11-12 years implemented the semantic task, "write the letter O", which was estimated $6.18 \pm 0.13$ points. Leading in the management of this action is the highest cortical level E. Morphologically these are the highest layers of the cerebral cortex. We emphasize that managing higher symbolic coordination (speech and writing), this level always plays a leading role.

We considered that as a result of the evolutionary process cortical nerve functions level E dominates all the previous levels. Therefore, the functionality of this level is the highest, which is manifested, as noted by A. I. Shinkaruk in oral activity in informative speaking and the relevant engine components and the impact of speech on all motor actions regardless of what level of construction of movements in their regulation is the leading. At level $\mathrm{E}$ of psychomotor activity, according to the author, acquires its highest manifestations, it could be far beyond a specific space and time, and muscle movement is the most collapsed, and transferred to the internal plan. So, the semantic task, "write the letter $\mathrm{O}$ " is a much more difficult than the semantic task "draw a circle". Despite this, the second surveyed group coped with it better with the harder tasks, the difference between the middle arithmetic statistically significant $\mathrm{P}<0,01$. So, the semantic task in the psychomotor action is the factor that determines the dynamics and content of mental reflection of the movements, morphological education, which are brought to management of the action,afferentation and efferention, mechanisms of regulation of movements and other components of the functional agencies which implement the action.

In psychomotor the different types of semantic tasks be can distinguished depending on what they focus on: coordination; the manifestation of physical qualities; on connecting movements to the environment; on the "binding" motions to the "body scheme"; on transfer of certain information; to attract certain levels of control of movements. In the latter case it is especially noticeable, as observations show, that the semantic task of motor actions are the factor that determine the leading level of construction of movements in its management. 
Our pilot study at the same time proved the existence of causal relationships between changes in semantic tasks that are solved in the process of motor activity and neurological mechanisms of movements. Different semantic tasks form different functional bodies or various functional systems. And when you consider that neural activity has a high "plasticity", the involvement of various semantic tasks in rehabilitation of persons with neurodevelopmental disorders will not only "enable" the existing functional bodies, but also rearrange them, compensating for specific developmental defects. In addition, the representation of mental functions in the Central nervous system is not local but systemic.

For mentally retarded children, the principle of changing the semantic tasks motor actions in the process of assimilation opens up new possibilities of rehabilitation. Because children with congenital or early acquired disorders of intellect are usually observed certain violations of psychomotor. It is important for them to form correct images of the action.

The use of semantic tasks of psychomotor actions for children burdened with intellectual disabilities, as observations show, fosters their skills for the realization of motor functions, especially exercise, household, and the labor action, as well as enrichment of their behavior and speech. Performing the physical exercises with a specific semantic task is a specified corrective job after as the flaws in the movements are characterized for children oligophrens. Even when children with mental disabilities of coordination of movements and the level of development of physical qualities are not inferior to healthy peers, however, less ability to rebuild psychomotor stereotypes and the ability to strong-willed efforts in terms of increasing muscle fatigue. In general, the mentally retarded children have reduced plasticity of the movements, and semantic tasks, differentiated by levels of movement construction can contribute to its improvement.

So, it is established that mentally retarded children with damaged thalamo-pallidar level B movements may be relatively better preserved parietal-premotor level D. Accordingly, children with congenital or early acquired intellectual disabilities can best perform semantic tasks, which is the leading level of actions with objects and semantic chains D and implement semantic tasks worse, for which the leading level is the level of coordinated movements and standard stamps B. and this is when the semantic task in the parietal-premotor level is much more difficult than the semantic tasks on thalamo-pallidar level. Moreover, children of 11-12 years burdened with intellectual disabilities can best perform their semantic task, "write the letter "O" for which the leading is pyramido-striatal level of 
construction of movements $\mathrm{C}$. The reason is that in the surveyed mentally retarded children, with all the "patchiness" of damage of the Central nervous system, the best preserved is the highest cortical levels of movement construction E, and pyramido-striatal level of spatial fields C has more damages. This is the kind of partial functional levels of construction of movements of mentally retarded children.

\section{CONCLUSIONS}

Developed by M. Bernstein the theory of levels of construction of movements is also the system of semantic tasks as was shown affect the coordination of movements of the subject, and his psychomotor capabilities at different levels are characterized by partiality, both in norm and in pathology.

The same surveyed person has different levels of development of skills of regulation of motor actions on different levels of the building. Each examinee is characterized by its own profile of skills development regulation of motor actions in the structure of the levels of movement construction.

Mentally retarded children of 6-7 years can show a higher expression of coordination of movements as they perform complex actions (cap off) and lower levels when performing simple actions (raise your hand), since these children better preserved parietal-premotor level of actions with objects and semantic chains D than thalamo-pallidar level B or coordinated movements and standard types. So, different levels of movement construction are responsible for implementing various semantic tasks.

Children aged 11-12 years with a congenital or early acquired persistent disorders of cognitive activity may have higher manifestation of coordination at the highest cortical level $\mathrm{E}$ (semantic task, "write the letter "O") than pyramido-striatal spatial fields C (semantic task "draw a circle"), located much lower. So, the semantic task determines the coordination of movements of mentally retarded children and the senior level of their construction during the execution of externally similar actions.

Performing semantic tasks is a mean of rehabilitation of a person with neurodevelopmental disabilities, as between semantic tasks that are implemented in the process of motor activity and neurological mechanisms are the causal relationship. So, different semantic tasks form different functional systems, a temporary combination of forces able to carry out a specific achievement. Restructuring of existing and formation 
of new functional organs may contribute to compensate for defects of the development of psychomotor.

\section{SUMMARY}

The results of study of the problem of manifestation of semantic tasks implemented by the subject of psychomotor activity, on the motor of skills of action both in norm and in pathology are presented in the work. The activity approach, which is elaborated in psychology is analyzed and selected as a base of research of features of regulation of motor actions, by applying the semantic task. It was noted that for the understanding of the implementation of semantic tasks in functional organs, it is advisable to apply the theory of levels of construction of movements by N. Bernstein. It is emphasized that there is no definite total score of psychomotor giftedness of the person, and for coordinating the setup of a subject for performing a wide range of motor actions you can use the system of exercises, which is represented as leading on all levels of movement construction. It is emphasized that the semantic task with maximum manifestation of those or other components of psychomotor qualities determines the content of the functional organ that provides the corresponding achievement. It is found that there is a relationship between the semantic content of the task and demonstration of psychomotor qualities of the subject.

It is determined that the opportunity to implement one of the semantic tasks may interfere with the other, and it is possible to identify that the various components of the same quality are poorly connected among themselves. The analysis of the effect of semantic tasks that operate in the structure of the levels of movement construction on psychomotor abilities of a person is made. The psychological features of the implementation of semantic tasks of motor actions by mentally retarded children are analyzed, which determine the change of coordination of movements of mentally retarded children during the fulfillment of externally similar actions with different semantic tasks, the possibility of using them as means of rehabilitation of persons with psychomotor disorders, the results of studies of the relationship between the individual semantic tasks and leading levels of movement construction are presented that encourage the search for individually suitable semantic tasks.

The program of skills development of regulation of motor actions using level-structured semantic tasks is proposed. 


\section{REFERENCES}

1. Бернштейн H.A. Физиология движений и активность / Н.А. Бернштейн; под. ред. О.Г. Газенко, изд. подгот. И.М. Фейгенберг. - М. : Наука, 1990. - 495 с.

2. Жиляк Н.В. Психологічні особливості регуляції моторних дій за допомогою смислових завдань: монографія / Н.В. ЖилякКам'янець-Подільський : Медобори-2006, 2015. - 150 с.

3. Ильин Е.П. Психомоторная организация человека: учебник для вузов / Е.П. Ильин. - СПб. : Питер, 2003. - 384 с.

4. Клименко В.В. Психологія спорту: навч. посіб. для студ. вищ. навч. закл. / В.В. Клименко. - К. : МАУП, 2007. - 432 с.

5. Малхазов О.Р. Психологія та психофізіологія управління руховою діяльністю: монографія / О.Р. Малхазов. - К. : Євролінія, 2002. $-320 \mathrm{c}$.

6. Роменець В.А. Історія психології XIX початку XX століття / В.А. Роменець. - К. : Вища школа, 1995. - 614 с.

7. Шинкарюк A.I. Рівні побудови рухів і смислова структура діï / А.І. Шинкарюк. - Кам'янець-Подільський: ФОП Сисин О.В., 2008. - 200 c.

8. Шинкарюк А.І. Психологія діяльності: навчальний посібник / А.І. Шинкарюк, В.А. Шинкарюк, Р.Т. Сімко; за заг. ред. А.І. Шинкарюка. - Кам'янець-Подільський: Оіюм, 2018. - 208 с.

9. Maslow A.H. Motivation and personality (3 rd ed.) / A.H. Maslow. - New York. : Harper and row, 1987. - 347 p.

10. Vealey, R. Personality in sport: A comprehensive view. In T. Horn (Ed.), Advances in sport psychology Champaign, IL: Human Kinetics. - 1992. - P. 23-59.

Information about the authors: Zhilyak N. V.

Ph.D. in Psychology, Senior Lecturer at the Department of General and Practical Psychology of the Kamianets-Podilskyi National Ivan Ohiienko University 61, Ohiienka str., Kamianets-Podilskyi, 32300, Ukraine

NatalieZhyljak@ukr.net ORCID: 0000-0002-3772-6687 Researcher ID: G-5784-2019 


\section{CONCLUSIONS}

Summing up the scientific legacy of the authors of the monograph, it is possible to emphasize a wide range of theoretical and applied searching for the development of modern pedagogical and psychological knowledge. The educational space maximally covers all the age categories from preschool to adult and determines the main problems, tasks as well as applied and scientific approaches to their solution. Before modern education, first of all, there arises the question of creating a developing environment for the progressive development of a child's consciousness and behaviour, promoting the development of a creative personality and the like. This concerns, above all, preschool age as the most sensitive for the assimilation of creative experience in communication and joint activities with adults.

In psychological science, an important place is also occupied by the issue of the formation and development of a creative personality during training, in the student period, during professional self-determination. The organization of the educational process in this way, when students' initiative is stimulated, their confidence in their own abilities and capabilities is formed, is an important factor in the formation of a creative personality.

In modern conditions, the ability and willingness of a person to adapt to new and unexpected situations is becoming increasingly important, and determines the feasibility of the concept of adult education as a process of personal, social and professional development of a person during his or her life.

This range of issues determines one of the most important tasks of modern education, namely: the introduction of innovative teaching methods. A promising area of such innovation is pedagogical design.

As a leading institution of socialization, the educational system has specific features: the presence of professional socialization, the purposefulness of influence on the restoration of the social system (conservatism), the presence of a unified model of socialization (unification). This causes its stability, lack of flexibility and partial marginalization of the pedagogical community, which should play a significant role in shaping the social picture of the young people's world. But the aging of the pedagogical personnel of a general education school, the outflow of the youth and socially mobile educators from it in favour of educational institutions with a non-state form of ownership make it difficult to form adequate life guidelines. 
Among such problems is the individual's going beyond gender-based stereotypes, hidden gender discrimination. Of particular importance is the question of finding methods that will reduce the level of its manifestation, since the professional of the future is a gender-competent professional. Unfortunately, studies of the components of professional competence of future specialists and namely the ability to design has not been covered enough by Ukrainian and foreign researchers. The main task of research is building a model for the formation of professional competence of future specialists based on the practical application of the education model in foreign countries from the point of view of the competence approach.

The introduction of inclusive education exacerbates the need for modern innovative methods of rehabilitation, one of which is the implementation of semantic tasks. It was found that each studied person had his own profile of regulation of motor actions.

Global transformations of organizational reality and new requirements for a manager's work necessitate the development of a new concept of managerial education. The irrational concept is aimed to solve the problem of breaking the essence of the changes, their perception and reaction to them.

In connection with the recent events, the problem of studying the ethnopsychogenesis and ethnic consciousness of the Crimean Tatars is becoming relevant. The traditional culture of the ethnos is a way of group adaptation to the conditions of existence. It has been established that the originality of the Crimean Tatar ethnic consciousness is conditioned by the history of its origin and formation. Balancing communicative interaction in a multi-ethnic space is possible through the formation of assertiveness. 
Publishing house "Liha-Pres"

9 Kastelivka str., Lviv, 79012, Ukraine

44 Lubicka str., Toruń, 87-100, Poland

Printed by the publishing house "Liha-Pres"

Passed for printing: August 30, 2019.

A run of 150 copies. 